\author{
UNIVERSIDADE DE SÃO PAULO \\ INSTITUTO DE ENERGIA E AMBIENTE \\ PROGRAMA DE PÓS-GRADUAÇÃ̃O EM ENERGIA
}

HALINE DE VASCONCELLOS ROCHA

ESTUDO GEOLÓGICO DO POTENCIAL DE EXPLORAÇÃO E PRODUÇÃO DE GÁS NATURAL NÃO CONVENCIONAL NA BACIA DO PARANÁ: AVALIAÇÃO DA VIABILIDADE NO ABASTECIMENTO DA USINA TERMOELÉTRICA DE URUGUAIANA (RS). 
HALINE DE VASCONCELLOS ROCHA

\section{ESTUDO GEOLÓGICO DO POTENCIAL DE EXPLORAÇÃO E PRODUÇÃO DE GÁS NATURAL NÃO CONVENCIONAL NA BACIA DO PARANÁ: AVALIAÇÃO DA VIABILIDADE NO ABASTECIMENTO DA USINA TERMOELÉTRICA DE URUGUAIANA (RS).}

Dissertação apresentada ao Programa de Pós Graduação em Energia, Instituto de Energia e Ambiente da Universidade de São Paulo (PPGE/IEE/USP) para obtenção do título de Mestre em Ciências.

Orientador Prof. Dr. Colombo Celso Gaeta Tassinari. 
AUTORIZO A REPRODUÇÃO E DIVULGAÇÃO TOTAL OU PARCIAL DESTE TRABALHO, POR QUALQUER MEIO CONVENCIONAL OU ELETRÔNICO, PARA FINS DE ESTUDO E PESQUISA, DESDE QUE CITADA A FONTE.

FICHA CATALOGRÁFICA

Rocha, Haline.

Estudo geológico do potencial de exploração e produção de gás natural não convencional na bacia do Paraná: avaliação da viabilidade no abastecimento da usina termoelétrica de Uruguaiana (RS) / Haline Rocha; orientador: Colombo Celso Gaeta Tassinari - São Paulo, 2016.

147 f.: il.; $30 \mathrm{~cm}$.

Dissertação (Mestrado em Ciências) - Programa de PósGraduação em Energia - Instituto de Energia e Ambiente da Universidade de São Paulo.

1. Usinas termoelétricas - Uruguaiana (RS). 2. Gás naturalBacia do Paraná I. Título. 
Nome: Haline de Vasconcellos Rocha

Título: Estudo geológico do potencial de exploração e produção de gás natural não convencional na bacia do Paraná: avaliação da viabilidade no abastecimento da usina termoelétrica de Uruguaiana (RS).

Data da aprovação:

Dissertação apresentada ao Programa de Pós Graduação em Energia, Instituto de Energia e Ambiente da Universidade de São Paulo (PPGE/IEE/USP) para obtenção do título de Mestre em Ciências.

Conceito:

Banca Examinadora:

Prof. Dr. Colombo Celso Gaeta Tassinari - Orientador

Prof. Dr. Estanislau Luczynski

Prof. Dr. Edmilson Moutinho dos Santos

Prof. Dr. Carlos Henrique Grohmann
Instituição: Instituto de Energia e Ambiente (IEE), Universidade de São Paulo (USP)

Instituição: Instituto de Geociências (IG), Universidade Federal do Pará (UFPA)

Instituição: Instituto de Energia e Ambiente (IEE), Universidade de São Paulo (USP)

Instituição: Instituto de Energia e Ambiente (IEE), Universidade de São Paulo (USP) 


\section{AGRADECIMENTOS}

Registro aqui meus sinceros agradecimentos a todos que contribuíram direta e indiretamente para o desenvolvimento e conclusão deste trabalho.

À Universidade de São Paulo, Instituto de Energia e Ambiente e Programa de Pós-Graduação em Energia, pelo apoio institucional.

À Coordenação de Aperfeiçoamento de Pessoal de Nível Superior (Capes), pelo apoio financeiro.

Aos professores e amigos Edmilson Moutinho dos Santos, Hirdan Katarina de Medeiros e Estanislau Luczynski pelo apoio e amizade.

Ao meu querido orientador Colombo Celso Gaeta Tassinari pelo conhecimento e dedicação.

À minha família, por tudo. 
RESUMO

ROCHA, Haline. Estudo geológico do potencial de exploração e produção de gás natural não convencional na bacia do Paraná: avaliação da viabilidade no abastecimento da usina termoelétrica de Uruguaiana (RS). 2016. Dissertação (Mestrado em Ciências) - Programa de Pós-Graduação em Energia da Universidade de São Paulo, São Paulo, 2016.

A presente dissertação de mestrado consiste na realização de um estudo geológico acerca do potencial para exploração e produção de gás natural não convencional na Bacia do Paraná, regiões sul e sudeste do Brasil e norte do Uruguai. Com essa finalidade, foram analisadas as formações geológicas Irati e Ponta Grossa, situadas na porção sul da bacia e caracterizadas por seu potencial gerador de hidrocarbonetos. $\mathrm{O}$ estudo também inclui a avaliação da viabilidade do abastecimento da usina termoelétrica de Uruguaiana a partir desse recurso, considerando os aspectos geológicos, socioeconômicos e ambientais associados. O projeto visa incentivar o estudo à temática de recursos energéticos não convencionais, com destaque para o shale gas, principal fonte de gás natural não convencional explorada no mundo, além de ressaltar os benefícios na crescente implantação do gás natural na matriz energética brasileira, tanto em aspectos estratégicos quanto econômicos. O projeto propõe a elaboração de um modelo descritivo-comparativo baseado nos aspectos geológicos dos principais campos produtores de shale gas nos Estados Unidos, principal produtor mundial, por meio do qual é avaliado o potencial para ocorrência desse recurso nos folhelhos negros correspondentes às Formações Irati e Ponta Grossa, segundo parâmetros geoquímicos, petrofísicos e geológicos presentes em formações comprovadamente produtoras nos EUA: Marcellus, Barnett e Eagle Ford. O modelo descritivo tem finalidade de avaliar o potencial para exploração, produção e distribuição de gás natural não convencional nas regiões sul e sudeste do Brasil, as quais representam o maior mercado consumidor e demanda por energia no país. Com base na análise comparativa realizada, atribui-se às formações brasileiras potencial moderado a elevado para a geração de shale gas. Entretanto, a viabilidade no abastecimento da usina termoelétrica de Uruguaiana depende, além da geologia local, de fatores político-regulatórios ainda pouco consolidados no país para a incentivar a produção de recursos energéticos não convencionais.

Palavras-chave: Gás Natural Não Convencional, Shale Gas, Formações Irati e Ponta Grossa, Matriz Energética Brasileira. 
ROCHA, Haline. Estudo geológico do potencial de exploração e produção de gás natural não convencional na bacia do Paraná: avaliação da viabilidade no abastecimento da usina termoelétrica de Uruguaiana (RS). 2016. Master's Thesis (Master's in Science) - Graduate Programo n Energy, Universidade de São Paulo, São Paulo, 2016.

The presented Master's Thesis consists on a geological study of the potential for exploration and production of unconventional natural gas in the Paraná Sedimentary Basin, southern and southeastern Brazil, and northern Uruguay. Therefore, the geological formations Irati and Ponta Grossa, located in the southern portion of the basin, were analyzed in terms of its hydrocarbon generating potential. The study also includes the viability evaluation of this occurrence as a supply for a thermal power plant in Uruguaiana, considering the geological socio-economic and environmental associated aspects. The project aims to promote studies on the topic of unconventional energy resources, especially shale gas, the main unconventional source of natural gas exploited in the world; in addition to emphasizing the advantages in increasing the implement of natural gas into the Brazilian energy matrix, both in strategic and economic aspects. The project proposes the development of a descriptive and comparative model based on geological aspects of the major shale gas producing fields in the United States, the world's leading producer; by which we are able to evaluate the potential for occurrence of this resource in the corresponding black shale formations Irati and Ponta Grossa according to geochemical, petrophysical and geological parameters present in these proven producing formations: Marcellus, Barnett and Eagle Ford. The descriptive model was elaborated in order to evaluate the potential for exploration, production and distribution of unconventional natural gas in the southern and southeastern regions of Brazil, which correspond to the largest consumer market and energy demand in the country. Based on a comparative analysis, the Brazilian geological formations are quantified with a moderate to high potential for generating shale gas. However, the viability of using this resource as supply for thermal electricity generation in Uruguaiana depends, in addition to the local geology, to political and regulatory aspects, which are still poorly consolidated among the country, in order to encourage the production of unconventional energy resources.

Keywords: Unconventional Natural Gas, Shale Gas, Irati and Ponta Grossa Formations, Brazilian Energy Mix. 
Figura 1 - Representação gráfica da produção norte-americana de gás natural não convencional, indicando os tipos de reservas recuperadas e sua respectiva produção medida em trilhões de pés cúbicos em relação ao tempo 16

Figura 2 - Mapa dos Estados Unidos apresentando a distribuição de reservas de gás de folhelho. As bacias sedimentares estão identificadas como produtoras ou de potencial estimado 17

Figura 3 - Mapa mundial apresentando as bacias sedimentares com potencial gerador de gás de folhelho. As bacias em vermelho são as de potencial comprovado, e bacias em laranja, são as de potencial estimado 18

Figura 4 - Imagem da usina termoelétrica de Uruguaiana, sudoeste do estado do Rio Grande do Sul 20

Figura 5 - Representação esquemática de um sistema petrolífero e de elementos condicionantes à sua formação 25

Figura 6 - Classificação de recursos minerais em função de fatores geológicos e econômicos Figura 7 - Representação esquemática de previsão de Hubbert realizada em 1962 para a produção de óleo e gás natural de 48 estados americanos (em vermelho), versus a produção ocorrida em 2012 (em azul)

Figura 8 - Gráfico representativo do consumo mundial de energia primária desde a 1860 a 2000 44

Figura 9 - Representação esquemática dos principais tipos de depósitos de gás natural 47

Figura 10 - Representação esquemática da relação entre temperatura e profundidade de soterramento com tipo e quantidade estimada de petróleo gerado

Figura 11 - Projeção gráfica do consumo de energia primária, por combustível, nos Estados Unidos 53

Figura 12 - Projeção gráfica da geração de energia elétrica por combustível, nos Estados Unidos 53

Figura 13 - Mapa das bacias sedimentares norte americanas produtoras de shale gas 55

Figura 14 - Mapa do Brasil apresentando as bacias sedimentares com potencial para gás em folhelho

Figura 15 - Representação da geração de gás natural em relação à classificação e tipologia de carvão mineral 58

Figura 16 - Ilustração referente à disposição de camadas de carvão mineral saturadas em CBM. A: Representação de estágios de formação de carvão mineral com os respectivos processos envolvidos na geração de gás biogênico e termogênico (CBM). B: Representação dos possíveis modelos exploratórios de CBM, a partir de perfuração vertical e de perfuração horizontal 
Figura 17 - Mapa dos Estados Unidos apresentando a distribuição e dimensão das principais bacias sedimentares geradoras de coal bed methane (CBM)

Figura 18 - Digrama esquemático representando a evolução de sistemas diretos e indiretos de acumulações de Basin Centered Gas (BCG) ou tight gas 64

Figura 19 - Ilustração representando limites transicionais entes camadas rochosas de pressão normal, saturadas em água, e camadas em sobrepressão, com saturação em gás natural, e sua distinção em sistemas diretos (A) e indiretos (B) de BCG

Figura 20 - Mapa dos Estados Unidos apresentando a distribuição geográfica de depósitos conhecidos de BCG

Figura 21 - Representação esquemática de técnicas de perfuração vertical e horizontal. A: Formação saturada em hidrocarbonetos sendo exposta à perfuração horizontal, indicando os pontos de kickoff e entry. B: Recuperação por meio de perfuração convencional (vertical).. 71

Figura 22 - Representação esquemática da técnica de perfuração em rede, também denominada perfuração multi-lateral, onde diversos tubos de perfuração são acoplados à central de perfuração com a finalidade de possibilitar e explotação do fluido em diversas direções d durante o mesmo intervalo de tempo 72

Figura 23 - Mapa dos Estados Unidos representando áreas em que a técnica de perfuração horizontal vem sido implantada. Figura 24 - Mapa dos Estados Unidos representando áreas em que a técnica de perfuração horizontal vem sido implantada 73

Figura 24 - Bloco diagrama representando o funcionamento da técnica de fraturamento hidráulico em associação à técnica de perfuração horizontal

Figura 25 - Mapa dos Estados Unidos representando as principais áreas de utilização de fraturamento hidráulico

Figura 26 - Representação esquemática das técnicas de fraturamento hidráulico e perfuração horizontal e de seu respectivo impacto ambientai relacionado à contaminação de água subterrânea 76

Figura 27 - Gráfico representando, em vermelho, a taxa de emissão de dióxido de carbono, prevista em 1998; e a taxa atual de emissão, em verde 78

Figura 28 - Gráfico representando o recente declínio do uso de carvão mineral como fonte geradora de energia elétrica nos Estados Unidos, e o aumento do uso de gás natural como fonte energética, fator que implica na redução da emissão de poluentes 79

Figura 29 - Representação do ciclo de análise e exemplo de um pirograma obtido a partir de análise Rock-Eval 83

Figura 30 - Mapa representativo da disposição geográfica da formação geológica Marcellus, Bacia Appalachian 88

Figura 31 - Sessão estratigráfica representativa da formação geológica Marcellus, Bacia Appalachian 90 
Figura 32 - Representação da paleogeografia regional do Mississipiano superior (325 Ma), indicando a localização e o contexto geológico formacional da bacia sedimentar Fort Wort. 96

Figura 33 - Mapa paleogeográfico dos Estados Unidos representando as variações de profundidade presentes na bacia Fort Worth e arredores, indicando zonas mais favoráveis à ocorrência de gás natural não convencional (maiores profundidades)

Figura 34 - Sessões estratigráficas norte-sul e leste-oeste da bacia sedimentar Fort Worth, representando o posicionamento estrutural da formação Barnett ao longo da bacia 98

Figura 35 - Mapa representativo da localização e das principais feições tectônico-estruturais relacionadas à formação Eagle Ford, porção sul do estado do Texas 100

Figura 36 - Mapa de localização da Bacia do Paraná na Plataforma Sul-Americana 107

Figura 37 - Mapa de localização da Bacia do Paraná (contorno em vermelho) representando seu limites nos estados brasileiros (MT, MS, GO, MG, SP, PR, SC, RS) e países vizinhos (Paraguai, Argentina e Uruguai) 108

Figura 38 - Mapa Geológico simplificado da Bacia do Paraná; com contorno estrutural (profundidade) do embasamento cristalino 110

Figura 39 - Mapa do arcabouço tectônico da Bacia do Paraná 112

Figura 40 - Modelo paleotectônico da margem sul-ocidental de Gondwana durante o período Neo-Ordoviciano (Orogenia Oclóyica): fase de subsidência inicial da Bacia do Paraná (delimitação em linha tracejada)

Figura 41 - Coluna estratigráfica da bacia do Paraná 128

Figura 42 - Mapa de localização dos poços exploratórios presentes na Bacia do Paraná e dos pontos amostrados referentes ás formações Irati e Ponta Grossa 130 


\section{LISTA DE TABELAS}

Tabela 1 - Comparação (em mD) entre permeabilidades de reservatórios convencionais e não convencionais (gás em folhelho e coalbed methane-CBM)

Tabela 2 - Representação da composição média de gases naturais em relação à moléculas de hidrocarbonetos. Análise baseada em amostras de reservatórios situados na Europa, África e América do Norte

Tabela 3 - Tabela apresentando a distribuição mundial de reservas estimadas e comprovadas de gás de folhelho, organizada de acordo com a ordem de países com maiores potenciais para esse recurso

Tabela 4 - Uso comparativo do consumo de água (galões) para geração de energia (BTU) dentre diversas fontes energéticas 79

Tabela 5. Relação percentual de betume e sua classificação em relação à quantidade de matéria orgânica presente em rochas geradoras de hidrocarbonetos 80

Tabela 6 - Classificação do potencial petrolífero de rochas geradoras em função do teor de COT $(\%)$ 82

Tabela 7. Modelo Descritivo dos principais parâmetros analisados na avaliação da viabilidade geológica para a ocorrência de acumulações de gás natural não convencional em folhelhos. 87

Tabela 8 - Análise comparativa dos campos Marcellus, Barnett e Eagle Ford, comprovadamente geradores e produtores de gás natural não convencional 104

Tabela 9 - Resultados obtidos em análises de COT, pirólise Rock-Eval em amostras das formações Irati e Ponta Grossa, Bacia do Paraná

Tabela 10 - Aplicação dos parâmetros essenciais à ocorrência de gás natural não convencional às formações geológicas Irati e Ponta Grossa, Bacia do Paraná 131

Tabela 11 - Análise comparativa dos parâmetros essenciais à ocorrência de gás natural não convencional entre as formações geológicas Marcellus, Barnett, Eagle Ford, Irati e Ponta Grossa 135 


\section{SUMÁRIO}

1 Introdução

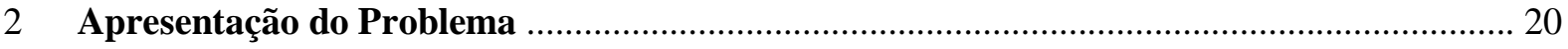

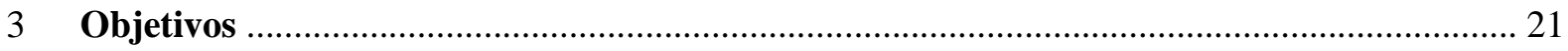

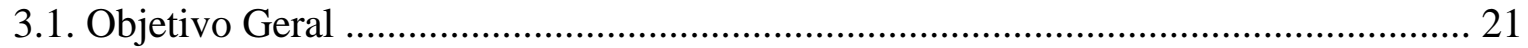

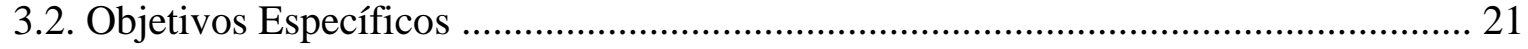

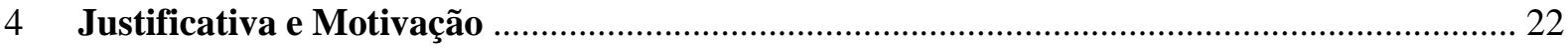

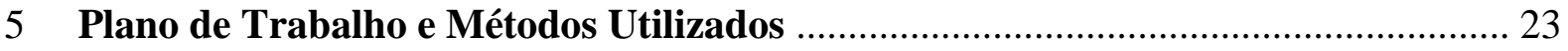

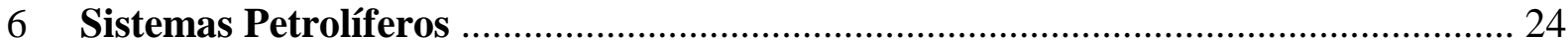

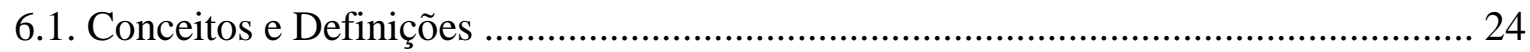

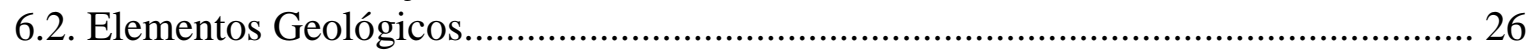

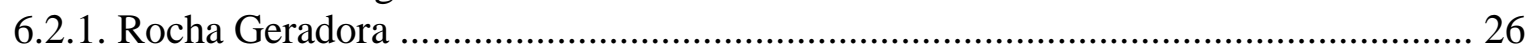

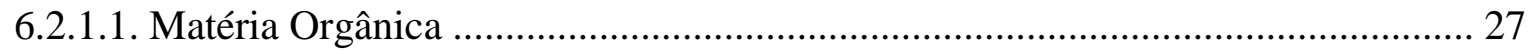

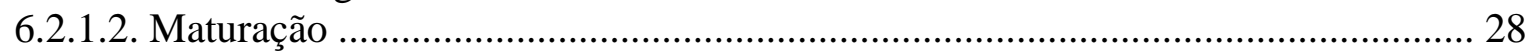

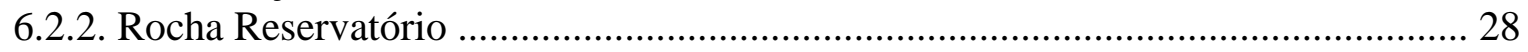

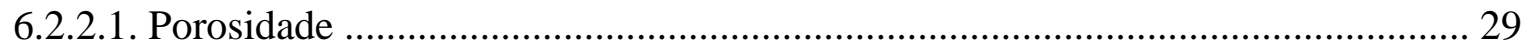

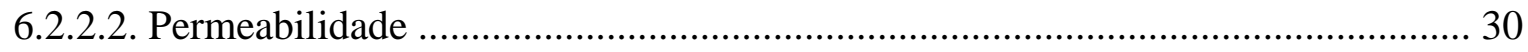

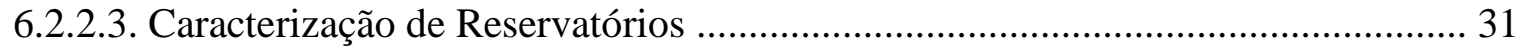

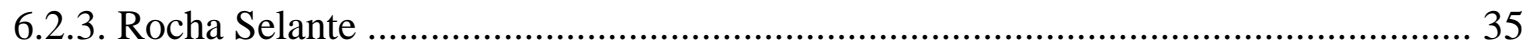

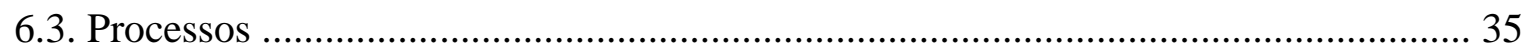

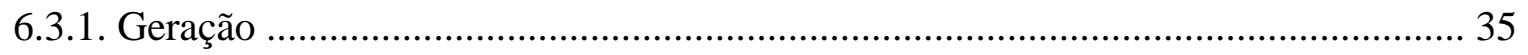

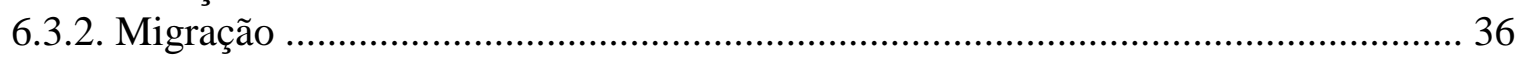

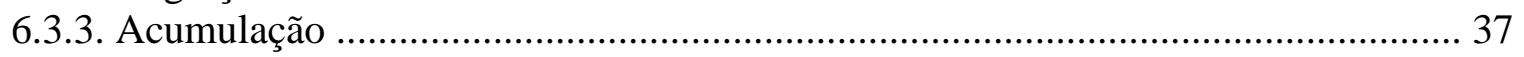

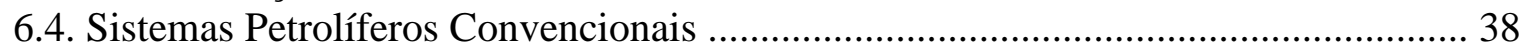

6.5. Sistemas Petrolíferos Não Convencionais ................................................................ 39

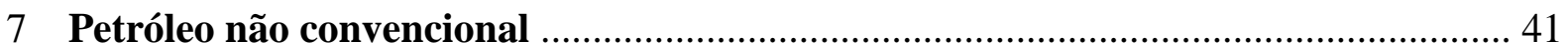

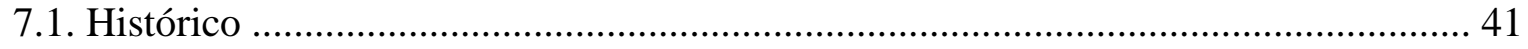

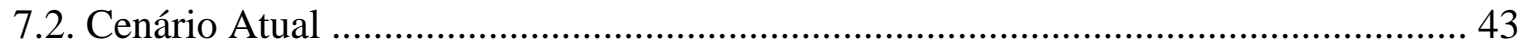

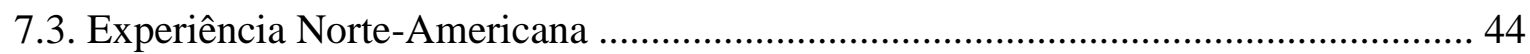

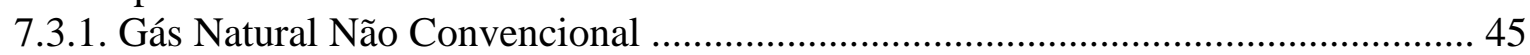

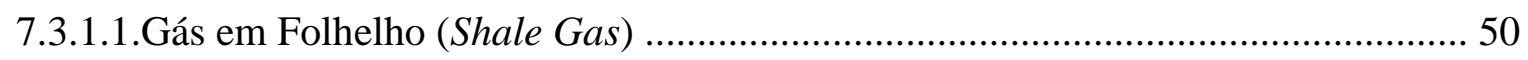

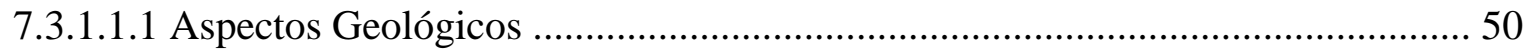

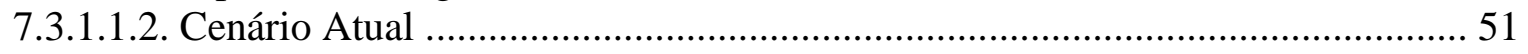

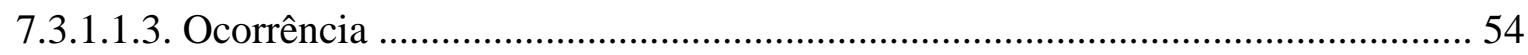

7.3.1.2. Metano em Estratos de Carvão (Coalbed Methane - CBM) ................................. 56

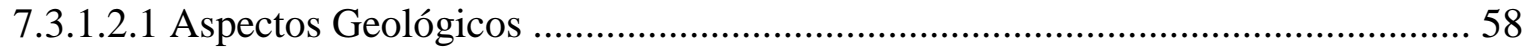

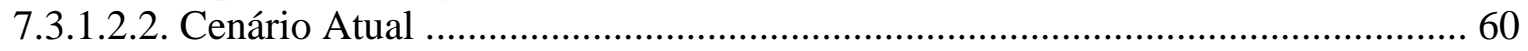

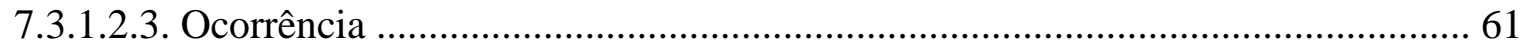

7.3.1.3. Gás em Reservatórios de Baixa Permeabilidade (Basin Centered Gas - BCG e Tight Gas) .... 62

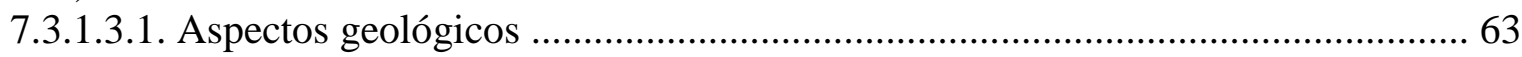

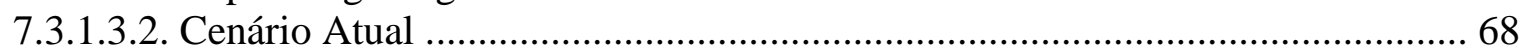

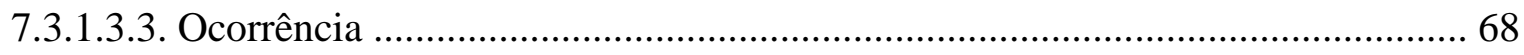

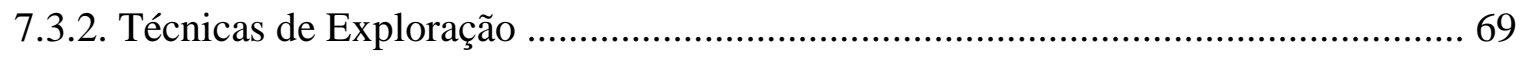




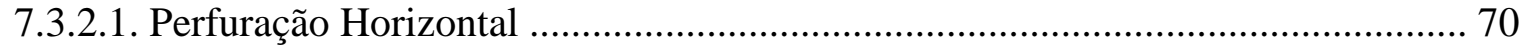

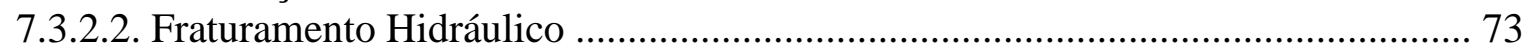

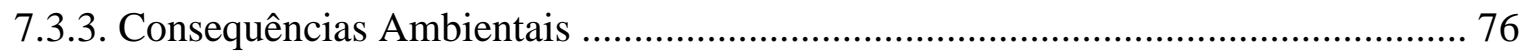

8 Caracterização De Campos Produtores De Gás Natural Não Convencional ……….............. 80

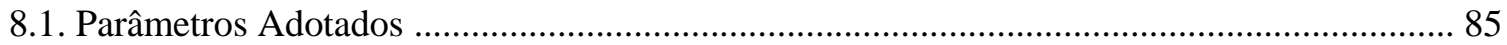

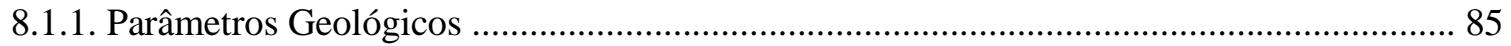

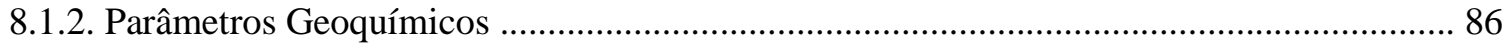

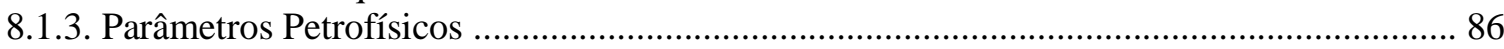

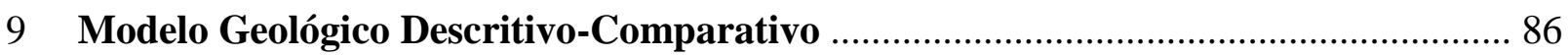

9.1. Principais Campos Produtores de Gás Natural Não Convencional ............................. 87

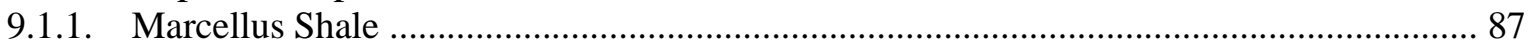

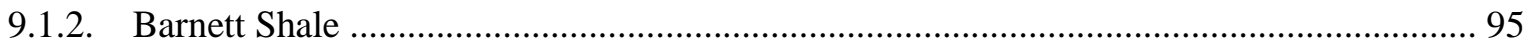

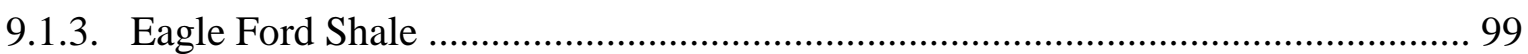

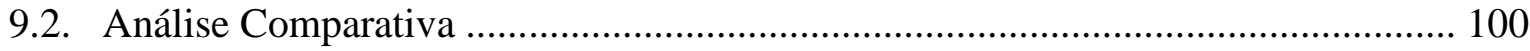

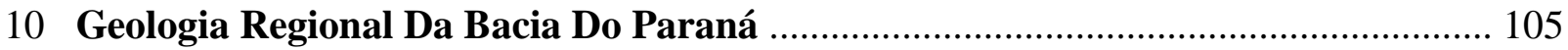

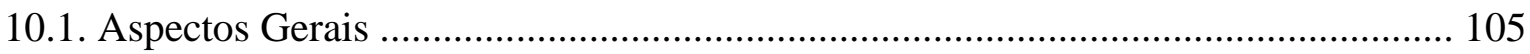

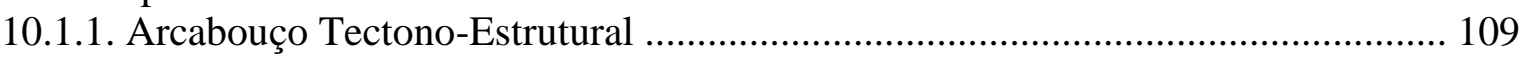

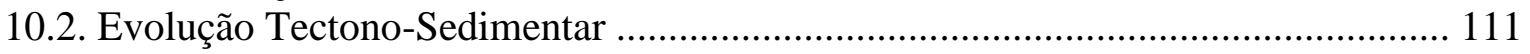

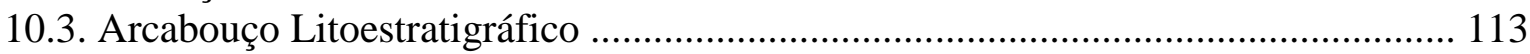

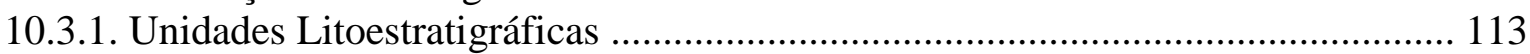

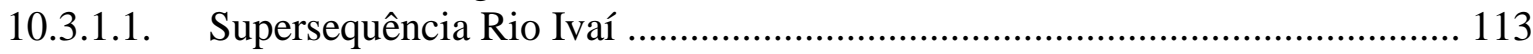

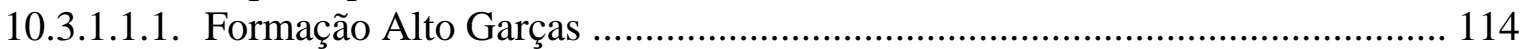

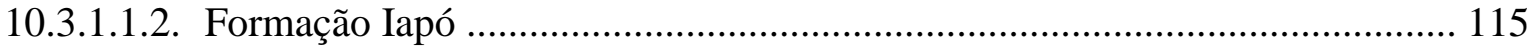

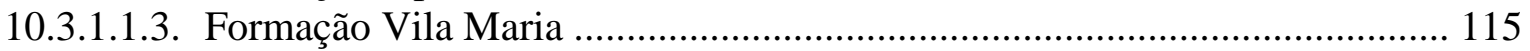

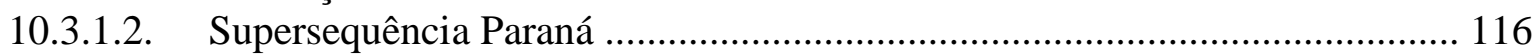

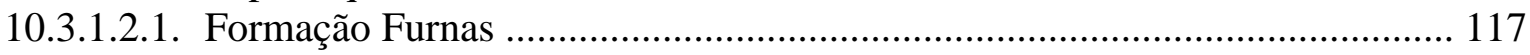

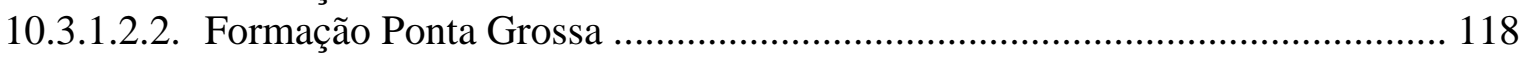

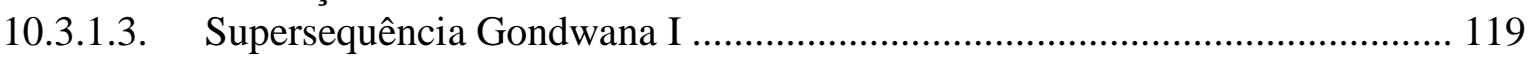

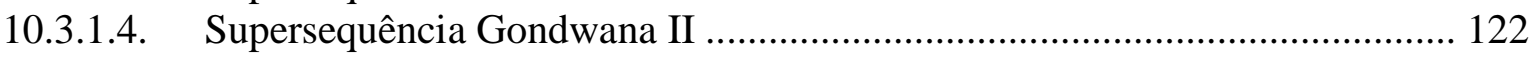

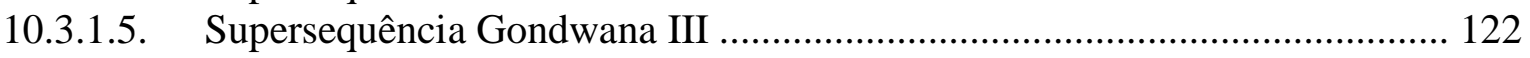

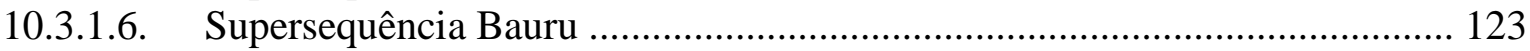

11 Potencial Para Geração De Hidrocarbonetos ....................................................... 126

11.1. Caracterização Geológica das Formações Irati e Ponta Grossa .................... 127

12 Histórico Da Exploração Petrolífera Na Bacia ....................................................... 132

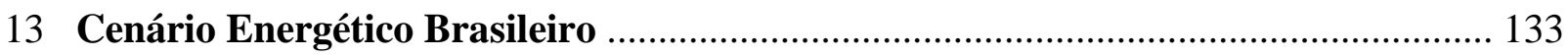

13.1. Usina Termoelétrica de Uruguaiana .............................................................. 133

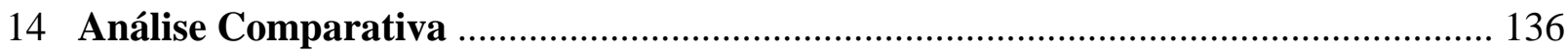

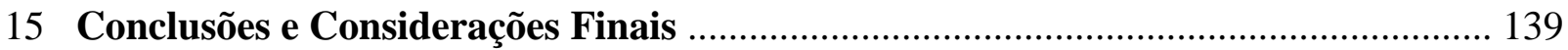

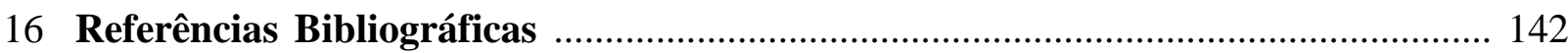




\section{INTRODUÇÃO}

A constante busca por recursos energéticos tem resultado em diversos avanços no setor de hidrocarbonetos não convencionais. Pesquisas realizadas pelo U.S.Geological Survey (USGS) constataram que gás natural não poderia ser apenas explorado em reservatórios de configuração geológica convencional, como por exemplo, em trapas anticlinais, mas também poderia ser encontrada em rochas de baixa permeabilidade: propriedade que permite o papel de geradora, reservatório e selante a um mesmo pacote rochoso, caso do folhelho. A descoberta revolucionou a indústria petrolífera dos Estados Unidos que, a partir do desenvolvimento de técnicas de exploração adequadas, tornou economicamente viável a exploração desse recurso.

As principais técnicas de exploração de sistemas não convencionais foram desenvolvidas nos Estados Unidos a partir de estudos realizados na formação Bakken, bacia sedimentar Williston, em North Dakota; e são denominadas hydraulic fracturing e horizontal drilling. O primeiro termo refere-se à técnica de faturamento hidráulico, que vem sendo utilizada desde 1940 e consiste basicamente na injeção de grande volume de água sob alta pressão, em associação com areias e compostos químicos, a uma formação saturada em petróleo com o objetivo de fraturar a rocha e gerar uma rota de passagem para o fluido explorado. Outra técnica de exploração, denominada perfuração horizontal, emergiu na década de 1980; quando avanços tecnológicos permitiram que operadores perfurassem até determinadas profundidades para em seguida realizar uma perfuração em ângulo, ou até mesmo completamente horizontal. Essa técnica veio a permitir um maior acesso ao reservatório, resultando em maior recuperação do hidrocarboneto A partir desse conhecimento adquirido, empresas passaram a combinar ambas as técnicas de perfuração, trazendo inovação ao mercado e retornos lucrativos. No entanto, esse benefício econômico pode vir associado a elevados custos ambientais: visto que a técnica de exploração desse recurso inclui a injeção de milhões de litros de água geralmente associada a compostos químicos que, potencialmente, podem resultar na contaminação de aquíferos; torna-se necessária a avaliação e prevenção desses possíveis impactos ambientais (Yergin, 2011).

O termo shale gas, ou gás em folhelho, corresponde a depósitos de gás natural que se encontram retidos em formações pelíticas ricas em matéria orgânica (folhelhos negros) em decorrência do eventual estágio de sobrepressão em que se encontram. Folhelhos geralmente se caracterizam por sua baixa permeabilidade, fato que dificulta a produção direta de petróleo a partir desta litologia; antes considerada fonte não comercial, ou não econômica, de hidrocarbonetos. No entanto, esta permeabilidade reduzida dos folhelhos pode vir a atuar como 
um fator de retenção de gás natural no interior desse pacote rochoso, dentre as lamelas que acompanham a foliação. Folhelhos que contém quantidades significativas de gás natural apresentam as seguintes propriedades em comum: composição enriquecida em matéria orgânica (de 0.5 a 25\%) e geralmente se apresenta no campo de existência de gás termogênico (intervalo de temperatura, entre 120 e $180^{\circ} \mathrm{C}$, baixa permeabilidade: < $0,01 \mathrm{mD}$, e soterramento suficientemente elevados, convertendo o petróleo em gás natural). O gás gerado a partir desse processo pode ser contido em fraturas naturais do pacote rochoso, no interior de poros, e/ou adsorvidos ao material orgânico-sedimentar. A recuperação do gás retido em poros e fraturas se dá durante a atividade de desenvolvimento e produção do sistema petrolífero, enquanto que o gás adsorvido é liberado à medida que ocorre redução na pressão interna do reservatório. $\mathrm{O}$ gás natural não convencional, antes não economicamente acessível, começou a ser explorado significantemente a partir do desenvolvimento e aplicação das técnicas exploratórias mencionadas, as quais permitiram a viabilidade econômica da produção direta de petróleo a partir de folhelhos (Das Virgens, 2011).

A combinação entre as tecnologias de fraturamento hidráulico e a perfuração horizontal inovou o mercado petrolífero norte-americano e ficou conhecida como a Revolução do Gás Não Convencional (Yergin, 2011). Nos anos 2000, a produção de gás em folhelho representava apenas $1 \%$ da produção anual total de gás natural nos EUA; em 2010, a produção atingiu mais de $20 \%$ do total, e de acordo com a Energy Information Administration (EIA), a produção desse recurso atingirá $46 \%$ da produção total de gás em 2035. Atualmente, o gás de folhelho é o recurso não convencional mais explorado mundialmente, e corresponde a mais de $50 \%$ da produção não convencional dos EUA (Figura 1). De acordo com estudos e estimativas, a produção de gás natural nos EUA em 2011 foi calculada em 23.0 trilhões de pés cúbicos $\left(\operatorname{Tcf}^{1}\right)$, podendo chegar a 33.1 Tcf em 2040, o que representa um aumento de $44 \%$ em produção. Praticamente todo esse aumento de produção é decorrente da exploração de gás de folhelho (Figura 17), que cresceu de 7.8 Tcf em 2011 para 16.7 Tcf em 2040 (EIA, 2012).

\footnotetext{
${ }^{1} 01 \mathrm{Tcf}=28,32 \mathrm{Bm} 3$ ou $01 \mathrm{cf}=0,0283 \mathrm{~m} 3$.
} 


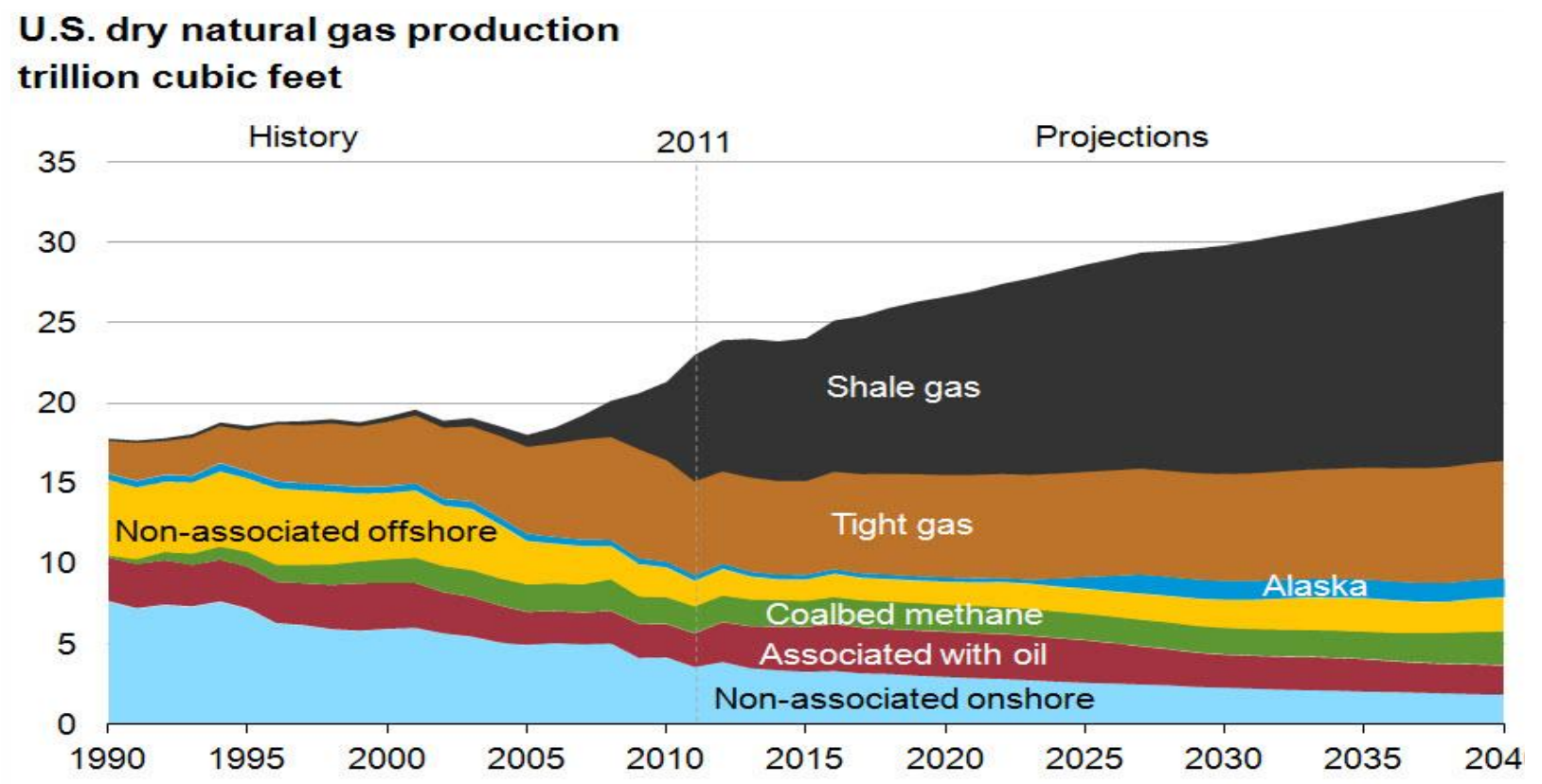

Figura 1 - Representação gráfica da produção norte-americana de gás natural não convencional, indicando os tipos de reservas recuperadas e sua respectiva produção medida em trilhões de pés cúbicos em relação ao tempo.

Fonte: EIA (2012)

A produção norte-americana de shale gas teve início na Formação Barnett, no estado do Texas e se intensificou nas formações Eagle Ford, também no Texas, e Marcellus, situado na região das Montanhas Apalache, leste dos Estados Unidos (EIA, 2012). Através de dados geofísicos de superfície e subsuperfície, associados a estudos geológicos, outras reservas desse tipo de gás foram encontradas ao longo do país (Figura 2). 


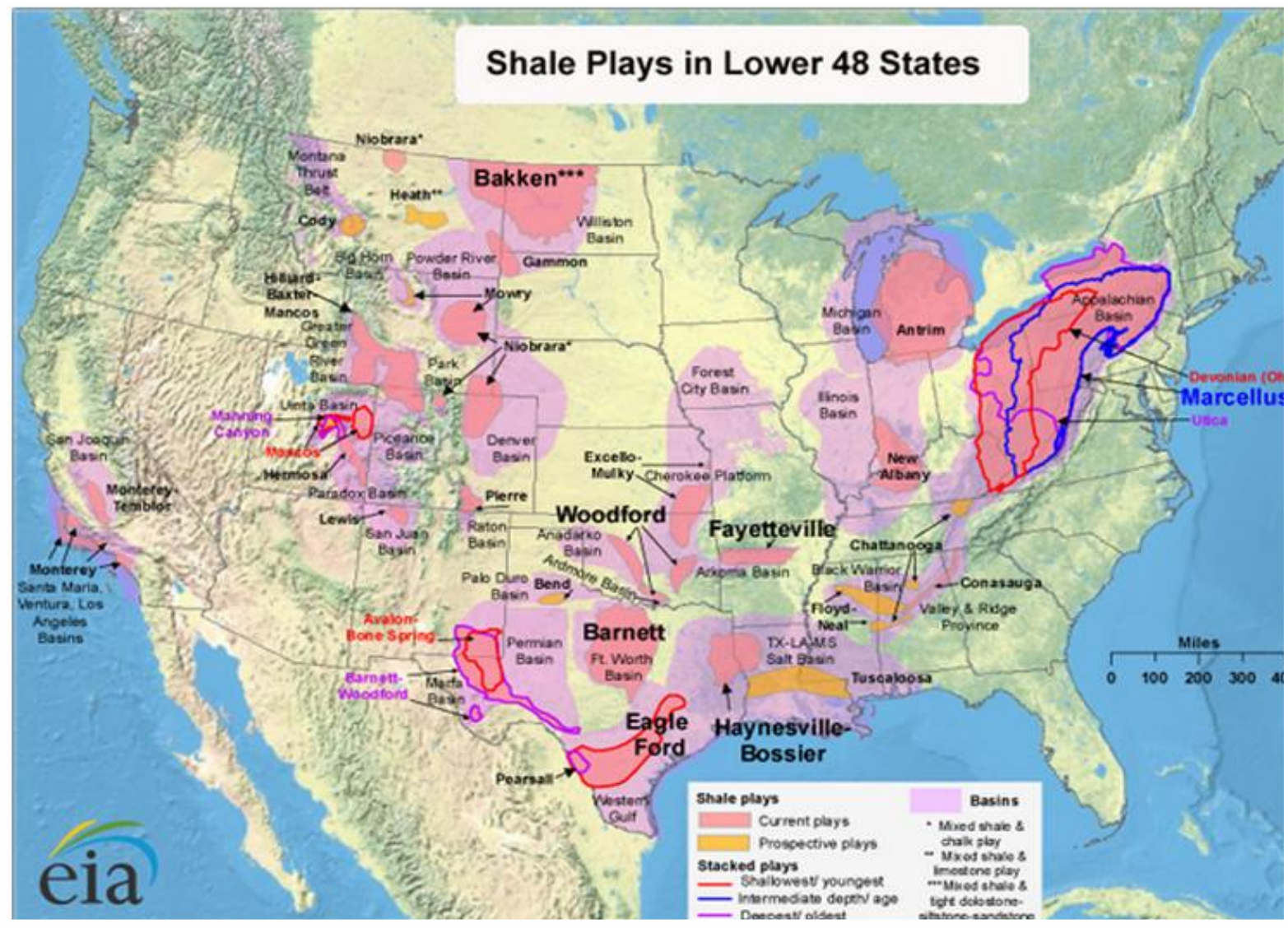

Figura 2 - Mapa dos Estados Unidos apresentando a distribuição de reservas de gás de folhelho. As bacias sedimentares estão identificadas como produtoras ou de potencial estimado. EIA (2012).

Fonte:

Beneficiado por esse avanço tecnológico, o gás natural passou a ter preço competitivo no mercado de recursos energéticos, obtendo vantagens em decorrência de seu menor teor de poluentes em relação a seus concorrentes: carvão mineral e óleo, por representar menor risco ambiental que outros combustíveis fósseis e energia nuclear, e vantagens também sobre fontes de energia renováveis, como a eólica, devido seu menor custo de produção.

De acordo com a EIA (2012), depósitos de gás em folhelho são amplamente distribuídos geograficamente (Figura 3), sendo que as maiores concentrações estão presentes na China, com valores estimados em 1.115 Tcf, seguidos por Argentina (802 Tcf), Argélia (707 Tcf), Estados Unidos (665 Tcf), e Canadá (573 Tcf). Apesar de diversos países apresentarem potencial geológico para a ocorrência de gás em folhelho, até o ano de 2013, apenas os Estados Unidos, Canadá, e China produziam esse recurso em escala comercial. O Brasil está presente em décima posição na lista de países com maior potencial para esse recurso, estimado em 245 Tcf. No entanto, apenas 14 reservas nacionais tiveram seu potencial comprovado, fato que reflete a insuficiência de pesquisas nacionais no setor de hidrocarbonetos não convencionais. 


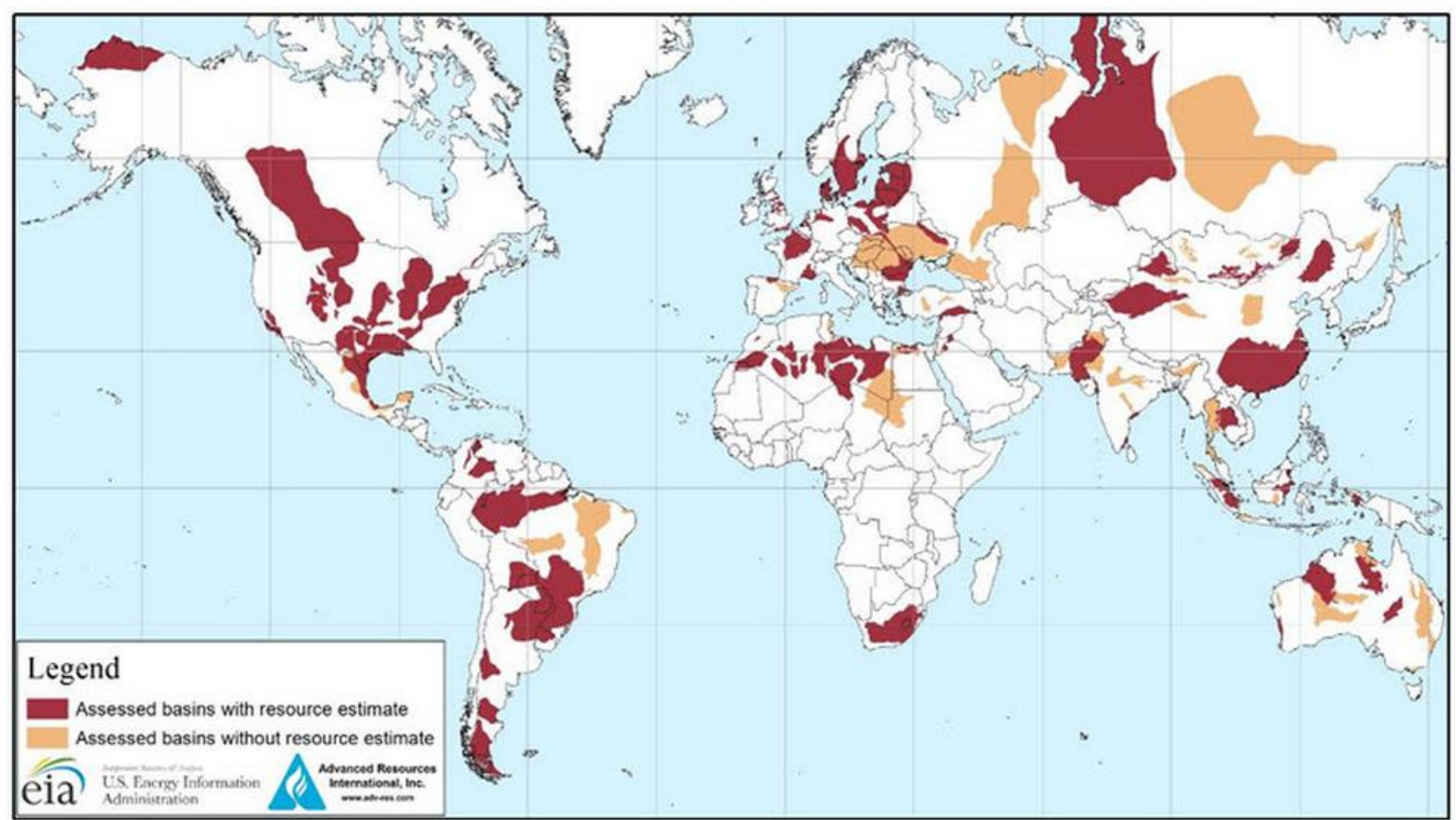

Figura 3 - Mapa mundial apresentando as bacias sedimentares com potencial gerador de gás de folhelho. As bacias em vermelho são as de potencial comprovado, e bacias em laranja, são as de potencial estimado. Fonte: EIA (2013).

No entanto, estudos e cálculos de reservas recuperáveis no Brasil, realizados pela ANP em 2013, indicam números promissores para o país, com estimativas de 414 Tcf em apenas cinco das principais bacias sedimentares brasileiras: Paraná, São Francisco, Parecis, Recôncavo e Parnaíba, fazendo com que o gás não convencional potencialmente marque um novo momento para a indústria petrolífera brasileira, além de incentivar a criação de uma grande indústria e mercado de produção nacional de gás natural e de uma forte impulsão no desenvolvimento do Brasil no setor energético.

Nesse contexto brasileiro de recursos energéticos, as regiões sul e sudeste do país se destacam por representarem o maior mercado consumidor nacional. Uma das principais reservas de combustíveis fósseis nessa região é atribuída à Bacia do Paraná, uma ampla região que consiste em uma ampla região sedimentar que inclui porções territoriais do Brasil meridional, Paraguai oriental, nordeste da Argentina e norte do Uruguai, totalizando uma área de aproximadamente 1,5 milhão de quilômetros quadrados. As formações geológicas de maior relevância em relação ao potencial petrolífero na bacia são as chamadas: Formação Irati, a qual data do período Permiano, e Formação Ponta Grossa, do Devoniano; ambas litologicamente constituídas por folhelhos, siltitos e carbonatos; (litologia favorável à geração de hidrocarbonetos). Estudos desenvolvidos pelo Serviço Geológico Brasileiro (CPRM, 2013) e pela ANP (2013) apontam elevado potencial para gás natural não convencional na Bacia do 
Paraná, estimado em 226 Tcf, e que estaria associado a estas formações geológicas. Esse potencial é atribuído a acúmulo de elevadas taxas de matéria orgânica associada a um ambiente redutor e condições de pressão, temperatura e soterramento adequadas à geração de gás em um modelo geológico não convencional (shale gas), o qual é caracterizado pela baixa permeabilidade das rochas na formação.

No atual cenário de crescente demanda por recursos energéticos e por geração de energia elétrica, a empresa AES Brasil, membro da corporação norte-americana (Applied Energy Services - AES) em parceria com a Companhia de Gás do Estado do Rio Grande do Sul (Sulgás), desenvolveu o projeto AES Uruguaiana com a finalidade de atender o mercado consumidor na região sul do país (Figura 4). A AES Uruguaiana é uma usina termoelétrica a gás natural que iniciou suas atividades em 2000 na cidade de Uruguaiana, sudoeste do estado do Rio Grande do Sul e próxima à fronteira com a Argentina e que seria responsável pelo fornecimento de gás por meio de uma parceria contratual entre a empresa petrolífera nacional YPF (Yacimientos Petrolíferos Fiscales - YPF), a AES e a Sulgás. Sua capacidade instalada é de 639,9MW, no entanto, a usina está com suas atividades paralisadas desde 2009 devido à interrupção do fornecimento de gás, justificado pelo governo argentino através da insuficiência da capacidade e infraestrutura de gasodutos em associação com a crise financeira em que se encontra o país. Em virtude da recente crise hídrica nacional, a usina de Uruguaiana teve suas operações retomadas em caráter emergencial e temporário em 2013, 2014 e 2015, a partir da importação de gás natural liquefeito da América Central e África (AES Eletropaulo, 2015). De acordo com dados fornecidos pela própria empresa, a usina térmica de Uruguaiana esteve em funcionamento por apenas sete meses desde 2008, em virtude da ausência de insumo de gás e de consequentes custos elevados. Diante desse cenário, o investimento e produção de gás natural nacional a partir de recursos não convencionais de energia tornam-se estratégicos para a seguridade da matriz elétrica brasileira e para a independência energética nacional. 


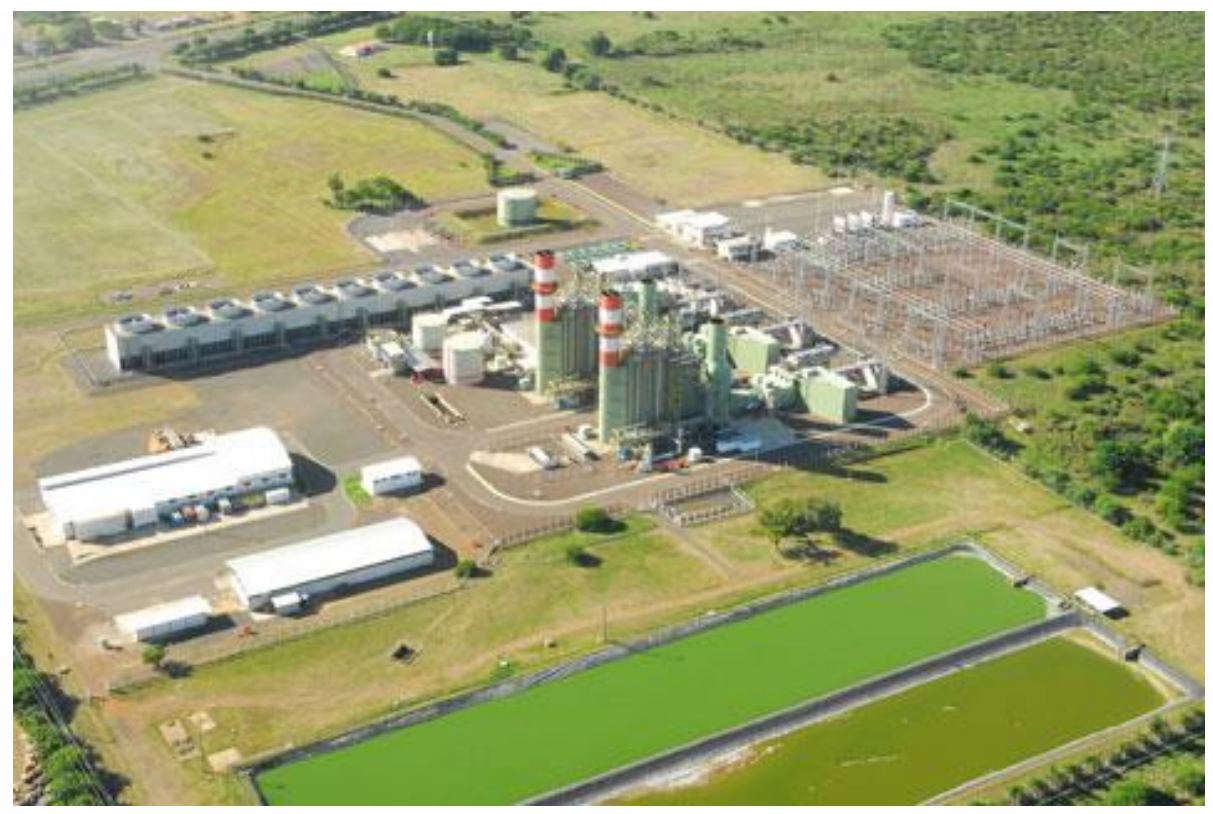

Figura 4 - Imagem da usina termoelétrica de Uruguaiana, sudoeste do estado do Rio Grande do Sul. Fonte: AES Brasil (2015).

O presente projeto de dissertação de mestrado objetiva a realização de maiores estudos referentes a essa temática de hidrocarbonetos não convencionais; abordando desde a geologia da Bacia do Paraná, com base em seu elevado potencial para a ocorrência desse recurso, e avaliando o potencial das Formações Irati e Ponta Grossa (folhelhos negros) com vistas à viabilidade de abastecimento de uma usina termoelétrica a partir de gás natural não convencional. Uma possível comprovação do potencial sistema petrolífero não convencional dessa formação, juntamente com uma análise da viabilidade desse abastecimento, pode representar um novo cenário diante da ausência de insumo de gás natural para a região sul e sudeste do país, além de perspectivas de maior participação e produção de gás natural nacional no setor energético brasileiro.

\section{APRESENTAÇÃO DO PROBLEMA}

O projeto visa contribuir com a avaliação geológica de formações potencialmente geradoras e reservatórios de hidrocarbonetos não convencionais em um cenário de escassez de informações acerca desse potencial e de carência de oferta de gás natural no mercado nacional. Nesse contexto, o foco de estudo se insere na seguinte problemática:

- Qual o real potencial para gás natural não convencional (shale gas) no Estado do Rio Grande do Sul em termos de ocorrência geológica? 
- Quais os possíveis impactos relacionados à exploração desse recurso na região, segundo aspectos socioeconômicos e ambientais?

- Quais as perspectivas de exploração de recurso segundo aspectos econômicos e regulatórios?

- Qual o consumo médio de gás natural na usina térmica de Uruguaiana para a geração de energia elétrica em função de sua capacidade geradora; e qual seria o potencial gerador de gás natural não convencional nas formações geológicas locais (Fm. Irati e Ponta Grossa)?

- Qual a viabilidade de abastecimento da usina termoelétrica a partir desse recurso?

\section{OBJETIVOS}

\subsection{Objetivo Geral}

O principal objetivo do projeto de pesquisa consiste na avaliação do potencial para gás natural não convencional das rochas sedimentares da Bacia do Paraná, mais especificamente das formações Irati e Ponta Grossa, em termos de ocorrência geológica, visando o abastecimento local para a usina termoelétrica de Uruguaiana, no estado do Rio Grande do Sul.

\subsection{Objetivos Específicos}

- Elaboração de um modelo descritivo geológico para gás natural não convencional com base nos aspectos geológicos dos principais campos exploratórios nos Estados Unidos: Barnett, Marcellus e Eagle Ford, a partir do qual será desenvolvida uma análise comparativa entre estes e as formações geológicas Irati e Ponta Grossa, na Bacia do Paraná, visando-se estimar seu potencial exploratório;

- Descrição e apresentação dos aspectos geológicos da Bacia do Paraná com a finalidade de avaliação de seu contexto geológico regional e da viabilidade geológica para a ocorrência de gás natural não convencional em comparação as bacias sedimentares comprovadamente geradoras nos Estados Unidos;

- Caracterização geológica das formações Irati e Ponta Grossa, com ênfase em suas características geoquímicas orgânicas, petrofísicas e faciológicas, e na identificação de parâmetros comparativos com formações geradoras nos EUA que auxiliem na determinação de seu potencial para geração de gás natural não convencional perante a 
evolução tectono-magmática e estrutural da bacia, e na determinação de sua viabilidade geológica para ocorrência desse recurso;

\section{JUSTIFICATIVA E MOTIVAÇÃO}

Segundo Yergin (2011), o gás natural pode ser considerado uma fonte energética relativamente segura, versátil e econômica. A combustão desse recurso é comparativamente mais limpa e eficiente, resultando em reduzidas emissões de poluentes em relação aos demais combustíveis fósseis (óleo e carvão). A utilização de gás natural na indústria petrolífera e energética vem proporcionando benefícios significativos para o meio ambiente, além de diminuir o custo operacional com manutenção de máquinas, transporte e armazenamento de combustível. Proporciona também a otimização do uso de matérias-primas e consequente melhoria nos processos de produção; aumenta a segurança, a eficiência dos equipamentos e a qualidade do produto final. $O$ gás natural tem substancial participação na indústria automobilística, alimentícia, têxtil, química, na produção de alumínio, vidro, cerâmica, papel, borracha, bem como nas siderúrgicas e metalúrgicas. Podendo ser utilizado em processos de aquecimento, resfriamento, geração de energia elétrica, e cogeração de energia térmica e elétrica, o gás natural se tornou a principal fonte energética nos Estados Unidos na última década (Yergin, 2011).

De acordo com a Companhia de Gás de São Paulo (Comgás, 2013), as discussões sobre as tendências e as novas tecnologias de produção e o uso de combustíveis que contribuem para preservação do meio ambiente ganharam força também junto aos órgãos governamentais. Esses órgãos se comprometeram a aumentar o uso das energias renováveis e o rendimento no uso de combustíveis, promover a cogeração e aumentar o uso do gás natural, devido às suas vantagens ambientais. Neste cenário, cresce a importância da política de incentivo à utilização do gás natural em maior escala. Suas vantagens tecnológicas, de segurança, e principalmente ambientais, fazem do gás natural uma importante alternativa na melhoria da qualidade do ar e na diminuição da emissão de gases que causam o efeito estufa. Isso vem proporcionando grande facilidade na obtenção dos certificados de qualidade ambiental pelas indústrias.

Nesse contexto, o Brasil se destaca por apresentar diversas bacias sedimentares com potencial gasífero; especialmente com potencial para shale gas, que equivale a elevadas concentrações de gás natural amplamente distribuídas ao longo do território nacional. Por outro lado, como a matriz energética brasileira é fundamentada em geração hidrelétrica, existe a vulnerabilidade às condições climáticas, caso da recente crise hídrica no Estado de São Paulo, 
decorrente de mudanças climáticas e reduções sazonais no fluxo hídrico associadas a problemas de gestão, resultando em uma crise de abastecimento de água e de eletricidade para a região. Em meio a essa atual crise energética, usinas térmicas foram acionadas em caráter emergencial visando atender a demanda local por energia elétrica. Uma das usinas, a termoelétrica AES Uruguaiana, previamente mencionada, que sofre influência da política externa argentina, possui tecnologia obsoleta e opera com custos elevados, é o objeto do presente estudo.

A usina térmica de Uruguaiana pertencente à companhia norte-americana AES, é abastecida por gás natural procedente da Argentina. $\mathrm{O}$ abastecimento é intermediado pela petrolífera YPF, estatizada em 2012 pelo governo argentino. Como resultado de problemas no cumprimento do acordo que anteriormente vigorava para o abastecimento da unidade, o Brasil passou a transportar gás natural até a região: a Petrobrás importa gás natural de Trinidad e Tobago, na região do Caribe, e transporta a carga por navio por mais de $7.700 \mathrm{~km}$ até os terminais de regaseificação da Argentina (A Folha de São Paulo, 2014). A Sulgás, (Companhia de Gás do Estado do Rio Grande do Sul), responsável pelo abastecimento de gás natural na região, compra o recurso da Petrobrás e o injeta na rede de gasodutos do país vizinho, elevando consideravelmente os custos de produção.

Diante desse cenário, a avaliação do potencial geológico para ocorrência de shale gas na Bacia do Paraná constitui um plano estratégico de garantia de abastecimento de energia para as regiões sul e sudeste do Brasil, as quais correspondem a maior demanda por energia elétrica no país. Além disso, estudos referentes ao potencial brasileiro para a exploração, produção, e distribuição desse recurso, desempenham um importante papel para a segurança energética brasileira, além de incentivar a indústria e o mercado nacional de gás natural, recurso potencialmente mais eficiente e menos poluente, justificando plenamente o desenvolvimento deste projeto.

\section{PLANO DE TRABALHO E MÉTODOS UTILIZADOS}

O plano de trabalho consiste na realização das seguintes etapas:

- Levantamento bibliográfico sobre os aspectos geológicos regionais da Bacia do Paraná;

- Levantamento bibliográfico sobre gás natural não convencional, com foco para shale gas desde seu contexto histórico, cenário atual, aspectos geológicos e impactos associados; 
- Levantamento de dados sobre os principais campos produtores de shale gas nos Estados Unidos (Barnett, Marcellus e Eagle Ford), considerando aspectos geológicos e desenvolvendo um modelo descritivo e comparativo acerca destes;

- Levantamento dos parâmetros comparativos estabelecidos pelo USGS para análise da viabilidade geológica e ocorrência desse recurso;

- Levantamento desses parâmetros nos folhelhos negros na Bacia do Paraná (Formação Irati e Formação Ponta Grossa) e nos folhelhos dos campos produtores americanos para fins comparativos;

- Análise comparativa desses parâmetros, sumarização desse estudo por meio de tabela (modelo descritivo para viabilidade geológica de shale gas) e especificação dessa análise para o Estado do Rio Grande do Sul em virtude de sua proximidade ao estudo de caso (usina térmica em Uruguaiana);

- Quantificação do consumo médio de gás natural pela usina termoelétrica AES Uruguaiana em decorrência de sua capacidade geradora de eletricidade e da potencial produção de gás natural não convencional a partir dessas formações geológicas com a finalidade de analisar a viabilidade desse abastecimento;

\section{SISTEMAS PETROLÍFEROS}

\subsection{Conceitos e Definições}

A indústria petrolífera, ao longo de décadas de exploração, constatou que a ocorrência de jazidas de hidrocarbonetos de volume significativo estava associada a determinados requisitos geológicos que ocorressem simultaneamente nas bacias sedimentares. $\mathrm{O}$ estudo destas características de maneira integrada e a simulação preliminar das condições ótimas para sua existência concomitante com a diminuição dos riscos exploratórios envolvidos nas perfurações de poços, que são operações de custo elevado, forma consolidados em um único conceito: o de sistema petrolífero (Magoon \& Dow, 1994). De acordo com a proposta de Magoon e Dow (1994) o conceito de sistema petrolífero foi definido como um sistema natural que inclui todos os elementos geológicos e processos necessários para a acumulação de hidrocarbonetos. Esses elementos geológicos correspondem ao conjunto: rocha geradora, rocha reservatório, e rocha selante (ou capeadora), que devem ser coexistentes e síncronos aos processos de geração, migração e acumulação de petróleo, associados à formação de trapas (Figura 5). 
Figura 5 - Representação esquemática de um sistema petrolífero e de elementos condicionantes à sua formação.

Fonte: Magoon \& Down (1994) apud Silva (2013).

Segundo Chapman (1976), a geologia de petróleo corresponde, de maneira abrangente, à geologia de bacias sedimentares, onde ocorrem as principais acumulações de hidrocarbonetos. Dessa maneira, o conhecimento sobre bacias sedimentares é imprescindível para se compreender o sistema petrolífero e os processos que nele atuam.

A geologia de petróleo não é apenas fundamentada em estudos geológicos, mas também baseada em experimentos e na prática exercida pela indústria petrolífera. Enquanto que a geologia estuda processos como a geração, migração e acumulação de hidrocarbonetos, em sua respectiva ordem, a indústria os estuda em ordem inversa, focando seus estudos no trapeamento, sendo este não apenas de caráter interpretativo como os demais processos, mas observável, concretamente definido, e mensurável. Estudos geológicos apontam que o petróleo tende a se acumular em pacotes mais profundos de sedimentos (bacias sedimentares) do que em relação a áreas de finos pacotes sedimentares, além da tendência de ser encontrado em rochas que datam dos períodos geológicos Mesozóico ao Triássico, e mais comum em trapas anticlinais do que em qualquer outro tipo de trapeamento (Chapman, 1976). No entanto, a experiência indica que a acumulação de hidrocarbonetos não segue uma regra fixa, sendo possível se encontrar campos de petróleo em cenários que fogem do trapeamento tradicional, como o caso aqui estudado de hidrocarbonetos não convencionais, onde, predominantemente, a permeabilidade reduzida de rochas geradoras e reservatórios faz o papel de trapa.

$\mathrm{Na}$ presente dissertação, será incialmente descrito o modelo convencional de acumulação de hidrocarbonetos, seguindo um modelo tradicional de sistemas petrolíferos. Em seguida, será apresentado um modelo não convencional, exemplificado por acumulação de gás 
natural em reservatórios de baixa permeabilidade, como o gás em folhelho (shale gas), foco do estudo realizado.

\subsection{Elementos Geológicos}

\subsubsection{ROCHA GERADORA}

Segundo Milani et.al.(2001), o elemento fundamental para a ocorrência de petróleo é a existência de consideráveis volumes de matéria orgânica adequada simultaneamente acumulada à deposição e formação de certas rochas sedimentares, denominadas rochas geradoras. São estas rochas que, quando submetidas a condições específicas de pressão e temperatura, são responsáveis pela geração de hidrocarbonetos em subsuperfície. Rochas geradoras são consideradas como principal elemento para a ocorrência de hidrocarbonetos, pois, quando ausente em uma baia sedimentar, não há possibilidade de substituição, ao contrário dos outros elementos constituintes do sistema petrolífero, que mesmo quando ausentes, podem ser de alguma forma compensados por condições geológicas excepcionais ou por coincidências adequadas, como o caso de sistemas petrolíferos não convencionais, melhor detalhados posteriormente na dissertação.

Rochas geradoras são predominantemente constituídas de material detrítico de granulometria muito fina (fração argila), sendo geralmente representadas por folhelhos e/ou carbonatos; indicadores de paleoambientes sedimentares de baixa energia que, por motivos diversos, experimentaram explosões de vida microscópica, que são fonte de matéria orgânica. Os remanescentes orgânicos autóctones (material planctônico) ou alóctones (material vegetal terrestre transportado para dentro do ambiente) são incorporados ao material sedimentar inconsolidado sob a forma de matéria orgânica diluída. Em princípio, quanto maior a quantidade de matéria orgânica, maior o potencial da rocha para geração de hidrocarbonetos. Entretanto, a incorporação desta matéria orgânica à rocha deve vir acompanhada da preservação de seu conteúdo original, rico em compostos de $\mathrm{C}$ e $\mathrm{H}$. Para isto, o ambiente deve ser muito empobrecido ou livre de oxigênio; elemento de propriedade oxidante, destruidor das concentrações de $\mathrm{C}$ e $\mathrm{H}$ em partículas orgânicas originais. De maneira geral, paleoambientes anóxicos favorecem a preservação da matéria orgânica e, consequentemente, a geração de petróleo. Geralmente, rochas sedimentares comuns apresentam teores de Carbono Orgânico Total (COT) inferiores a 1\%. Segundo Silva (2007), os valores mínimos de COT para que uma rocha seja considerada como potencialmente geradora são de aproximadamente 0.5 a $1.0 \%$, ao longo de toda a unidade geológica. O tipo de petróleo gerado depende fundamentalmente do 
tipo de matéria orgânica preservada na rocha geradora. Matérias orgânicas derivadas de vegetais superiores tendem a gerar gás, enquanto o material derivado de zooplancton e fitoplancton, marinho ou lacustre tende a gerar óleo (Milani et.al.2001).

O teor de matéria orgânica é o principal requisito para a geração de hidrocarbonetos em bacias sedimentares. Geralmente rochas geradoras contêm de 0,5\% a 2,0\% de seu peso em carbono orgânico para os folhelhos; e até 0,2\% para carbonatos; sendo rochas-fonte consideradas de bom potencial petrolífero contêm valores de COT em torno de 12\% (Milani et.al.2001). Ainda de acordo com Milani (op.cit.), as principais condições para que os sedimentos se tornem rochas-fonte são:

- A presença de matéria orgânica adequada e suficiente (COT\%).

- O tipo adequado de querogênio seja com potencial para óleo (oil-prone) ou com potencial para gás natural (gas-prone).

- Nível de maturação necessário à formação do petróleo.

\subsubsection{Matéria Orgânica}

Os principais representantes da matéria orgânica propícia para a geração de hidrocarbonetos são o plâncton (marinho e fluvial) e as bactérias; sendo estes também correspondentes à maioria da matéria orgânica preservada em sedimentos. A matéria orgânica adequada para a geração de petróleo é representada pelo fitoplâncton marinho, devido sua composição rica em lipídios (gorduras). O primeiro estágio na incorporação de matéria orgânica em sedimentos é a geração dessa matéria orgânica, sendo a fotossíntese o processo bioquímico essencial à produção dos precursores da matéria orgânica sedimentar que resultará em potenciais rochas geradoras de hidrocarbonetos. Satisfeita esta primeira condição, o fator principal passa a ser a existência de um ambiente anóxico (Milani et.al. 2001).

Aproximadamente $98 \%$ da matéria orgânica presente nos sedimentos corresponde a um material amorfo e de natureza insolúvel, denominado querogênio. $O$ termo querogênio foi inicialmente aplicado em 1912 por Crum \& Brown (apud Link, 1996) para descrever folhelhos pirobetuminosos na Escócia. Atualmente o termo é empregado para a fração da matéria orgânica sedimentar que é insolúvel na presença de solventes orgânicos. Segundo Link (op.cit.), o querogênio é um composto polímero insolúvel, de elevado peso molecular que compreende cerca de $90 \%$ da matéria orgânica de um folhelho. Os $10 \%$ restantes são betumes de composições variadas que, segundo alguns autores, correspondem ao querogênio termicamente alterado. Outros autores sustentam que, mesmo sob as condições mais favoráveis, um máximo de $15 \%$ da matéria orgânica sedimentar será convertido em hidrocarbonetos 
líquidos. Destes 15\%, não mais do que $15 \%$ dos hidrocarbonetos migrarão da rocha geradora, ou seja, cerca de $2,2 \%$ do total. A quantidade de petróleo gerado que formará acumulações comerciais também corresponde a essa faixa percentual.

\subsubsection{Maturação}

O estágio de maturação térmica de uma rocha geradora, ou seja, a temperatura na qual esta deve ser submetida para que ocorra a geração de petróleo, também influenciará no tipo de petróleo gerado. Em condições normais, uma rocha geradora inicia a transformação de querogênio em petróleo em torno de $60^{\circ} \mathrm{C}$. Inicialmente, forma-se um óleo de baixa maturidade, de caráter viscoso. À medida que a temperatura aumenta, o óleo gerado vai ficando mais fluido e quantidade de gás vai aumentando. Por volta de $90^{\circ} \mathrm{C}$, as rochas geradoras atingem seu pico de geração, expelindo grandes quantidades de óleo e gás. Com o aumento da temperatura até os $120^{\circ} \mathrm{C}$, o óleo fica cada vez mais fluido e mais rico em gás dissolvido. Nesta faixa de temperatura, a quantidade de gás predomina sobre a de óleo gerado, e o produto é considerado um condensado. Entre $120^{\circ} \mathrm{C}-150^{\circ} \mathrm{C}$, apenas gás é gerado pelas rochas-fonte (Link 1996).

\subsubsection{ROCHA RESERVATÓRIO}

Rochas reservatório são geralmente de composição detrítica e de granulometria de fração areia a seixo, caracterizando uma porosidade na qual o petróleo poderá ser armazenado e posteriormente extraído, sendo representativas de paleoambientes sedimentares de ata energia. Essas rochas normalmente correspondem a arenitos, calcarenitos e conglomerados diversos. Entretanto, qualquer rocha que contenha porosidade adequada, não necessariamente intergranular, mas de natureza diversa, como a partir de fraturamento ou dissolução, também pode fazer o papel de rochas reservatório (como rochas cristalinas fraturadas, mármores lixiviados, dentre outros exemplos). Os valores de porosidade mais comuns entre rochas reservatório variam de 5\% a 35\%, concentrando-se na faixa de $15 \%$ a 30\% (Link, 1996). A porosidade dessas rochas não apenas serve para armazenar, mas também como importantes rotas de migração de petróleo. Um reservatório de petróleo, para ser eficiente, deve ser relativamente poroso e permeável, além de conter algum tipo de barreira (armadilha) que contenha a migração do fluido. O processo de compactação dos sedimentos resulta na redução de porosidade e permeabilidade da rocha. No entanto, quando os sedimentos se apresentam saturados em fluidos não compressíveis (como água, óleo, ou gás natural), a porosidade só será reduzida com a liberação de parte desse fluido. Sendo assim, a taxa de compactação é 
diretamente relacionada à compressibilidade do fluido e pela taxa de expulsão do mesmo, que por sua vez, é controlada pela permeabilidade ou pela condutividade hidráulica da rocha que está sendo compactada (Chapman, 1976).

Compactação e condutividade hidráulica são fatores relacionados entre si e às propriedades de porosidade e permeabilidade de rochas. Sendo também importantes para o entendimento de reservatório de petróleo, especialmente nos casos de acumulações não convencionais apresentados no presente trabalho, representados pelos reservatórios de baixa permeabilidade.

\subsubsection{Porosidade}

Rochas sedimentares são constituídas por grãos de dimensões variadas que são agrupados por propriedades físicas ou químicas (cimentação). Os espaços vazios entre esses grãos correspondem à porosidade da rocha, medida como porcentagem em volume total da rocha. O máximo volume de fluidos que uma rocha reservatório pode conter equivale ao volume de poros presentes na rocha, sendo assim, se concretiza a importância de se determinar com precisão a porosidade. De acordo com Khamsin (2004), devido à variedade e complexidade envolvendo processos de sedimentação, diferentes tipos de porosidade podem ser gerados em uma rocha. São estes:

Porosidade efetiva: Quando os espaços vazios estão conectados e possuem potencial de fluxo através deles.

Porosidade não efetiva: Quando a porosidade está isolada (sem conexão).

Porosidade primária: Também chamada de porosidade original. Trata-se do espaço poroso que as rochas apresentam no momento da deposição. Normalmente é função da quantidade de espaços entre os grãos formadores das rochas. A porosidade original é reduzida por compactação e processos diagenéticos relacionados à água subterrânea.

Porosidade secundária: Causada por soluções (água subterrânea), recristalização e fraturamento. A porosidade secundária se desenvolve após a deposição sedimentar.

A porosidade de uma rocha é diretamente relacionada à compactação exercida sobre a mesma. A compactação faz parte do processo diagenético e inicia com o soterramento e pode continuar até profundidades de aproximadamente $9 \mathrm{~km}$. Sua principal implicação é no aumento da densidade da rocha e na redução de sua porosidade. No caso de material arenoso, a compactação resulta mínimas perdas de porosidade e permeabilidade; devido às propriedades 
do quartzo, a deformação se apresenta predominantemente elástica (reversível com a diminuição do peso exercido pelo pacote superior). A compactação de material argiloso resulta em elevada e permanente redução de porosidade e permeabilidade da rocha devido à deformação plástica característica de argilas (irreversível). A compactação de rochas carbonáticas ocorre em diferentes níveis, de acordo com a proporção de material plástico em sua composição (podem apresentar comportamentos semelhantes ao das argilas, mas geralmente sofrem pouca compactação mecânica) (Khamsin, 2004).

\subsubsection{Permeabilidade}

A permeabilidade de uma rocha corresponde à medida da facilidade com que a mesma permite a passagem de fluidos. A permeabilidade é um fator dependente da porosidade: quanto maior a porosidade, maior a permeabilidade de uma rocha. No entanto, a permeabilidade também depende da conectividade entre os poros, do tamanho e forma dos grãos, e da distribuição destes; além da atuação de fatores como a força de capilaridade, relacionada à saturação da rocha (Chapman, 1976). Com base nas informações de Chapman (op.cit.), podese afirmar que:

- Quanto maior a porosidade, maior a permeabilidade;

- Quanto menor o tamanho dos grãos, menor a porosidade e a permeabilidade;

- Quanto menor o tamanho dos grãos, maior a superfície de contato entre estes, resultando em uma maior fricção entre o fluido percolante e a rocha e, consequentemente, menor a permeabilidade.

A permeabilidade é medida em darcies (Darcy): $Q=(k / \mu) A\left(\mathrm{p}_{1}-\mathrm{p}_{2}\right) / \mathrm{B} \mathrm{L}$; sendo que:

- Q: taxa de fluxo $(\mathrm{bbl} / \mathrm{d})$

- K: permeabilidade (Darcy)

- $\mu$ : viscosidade de fluido (centipoises)

- A: área de fluxo em seção quadrada $\left(\mathrm{ft}^{2}\right)$

- $\mathrm{p}_{1}-\mathrm{p}_{2}$ : diferença de pressão (psi)

- L: comprimento da trilha de fluxo (ft)

- B: fator de formação de volume (bbl/bbl estocado)

A permeabilidade também sofre influência da pressão de capilaridade e da permeabilidade relativa: 
Capilaridade: Quando os poros da rocha diminuem de tamanho, a tensão superficial de fluido na rocha aumenta. Se há diversos fluidos na rocha, então cada um tem uma tensão superficial diferente, o que mostra uma variação de pressão exercida entre eles (pressão de capilaridade). Normalmente, a pressão de capilaridade é suficiente para evitar o fluxo de um fluido na presença de outro.

Permeabilidade relativa: Quando água, óleo e gás fluem através de reservatórios permeáveis, as taxas de fluxo podem ser alteradas pela presença de outros fluidos. Um único fluido flui através da rocha com sua própria taxa de fluxo, mas a presença de outro fluido pode alterar esta taxa de fluxo. Dessa maneira, pode-se afirmar que a taxa de fluxo pode ser alterado pela quantidade e tipo de fluidos presentes nas rochas, ou seja, o grau de saturação em fluidos da rocha e a natureza desses fluidos, a qual influência em sua capacidade de redução do espaço poroso.

Com o aumento na taxa de soterramento, consequentemente, o maior peso exercido pelo pacote sedimentar intensifica o processo de compactação, o qual rearranja os sedimentos de forma mais coesa, reduzindo a porosidade da rocha e/ou isolando alguns poros dos demais. No entanto, a compactação não apenas reduz o volume de poros em uma rocha, mas também pode vir a impedir o fluxo ou liberação do fluido presente, reduzindo também sua permeabilidade. Dessa forma, o fluido se apresenta trapeado em poros isolados na rocha, ou pela própria porosidade reduzida da mesma (Chapman, 1976). Este é o caso dos chamados reservatórios de baixa permeabilidade, exemplificados pelo Basin Centered Gas ou Tigh Gas (gás em estratos de baixa permeabilidade), ou pelo Gás em Folhelho ou Shale Gas, trapeado na própria rocha geradora em virtude dessa permeabilidade reduzida; posteriormente melhor abordados neste trabalho.

\subsubsection{Caracterização de Reservatórios}

As rochas sedimentares compreendem a essência dos reservatórios de petróleo: são as únicas rochas capazes de ser geradoras e reservatório, sendo também as únicas que possuem porosidade primária e permeabilidade suficiente a esta condição; e consequentemente responsáveis pela maior quantidade de petróleo armazenado. Outras rochas, como as ígneas e metamórficas, podem apenas atuar como reservatórios em menores escalas de acumulação. As condições essenciais para que uma rocha tenha potencial reservatório incluem porosidade e permeabilidade adequadas, além de outros fatores geológicos que influenciam nas propriedades dos reservatórios. São estes: intemperismo, erosão e deposição, os quais determinam o caráter do reservatório; fatores granulométricos como o tamanho e forma dos grãos; tipo de cimento e 
matriz; diagênese (taxa de compactação); fraturamentos; pressões de fluidos, além do tamanho e do tipo de reservatório em questão. Esses fatores são importantes uma vez que estão diretamente relacionados à porosidade e a permeabilidade de um reservatório (Link, 1996). De acordo com Link (op.cit.) estes fatores influenciam na qualidade de reservatórios da seguinte forma:

Tamanho dos grãos: Em rochas clásticas, o tamanho dos grãos pode ser bastante variável. Esta variação está relacionada a fatores como composição mineral, intemperismo, ambiente deposicional, além da distância e intensidade do transporte sedimentar. Neste contexto, podese afirmar que grãos maiores não-cimentados normalmente indicam maior porosidade e permeabilidade que grãos menores. Já rochas de granulometria mais uniforme são mais porosas e permeáveis que aquelas com uma variedade de tamanhos de grãos. De modo geral, rochas com grãos bem selecionados são melhores reservatórios do que rochas com menos grau de seleção.

Forma do grão: Esta propriedade está diretamente relacionada à porosidade: grãos esféricos tendem a aumentar a porosidade, enquanto que a angularidade fecha o espaço entre os grãos, reduzindo a permeabilidade: quando a orientação dos grãos é unidirecional, ocorre um aumento de permeabilidade ao longo dos eixos maiores (permeabilidade lateral), e redução nos eixos menores (permeabilidade vertical). Essa variação de permeabilidade pode ser exemplificada em rochas pelíticas: grãos achatados de folhelho não mostram permeabilidade normal à fissibilidade, mas mostram movimentação lateral de fluidos ao longo da compactação.

Compactação do grão: Grãos arenosos esféricos em arranjo aberto podem gerar porosidade de quase $48 \%$. Porém, os mesmos grãos em arranjo compacto mostram porosidade de quase 26\%, que não é alterada mesmo com mudança de carga das camadas superiores. Grãos esféricos bem selecionados e bem compactados produzem uma porosidade maior do que grãos angulosos e mal selecionados.

Matriz: A composição da matriz influencia no volume interno da rocha: uma diminuição no tamanho do grão da matriz e um aumento no grau de penetração da mesma reduzem a porosidade e a permeabilidade. Na realidade, o material fino reduz os espaços porosos entre os grãos maiores. Além disso, os materiais que compõem a matriz normalmente são alterados por 
diagênese, água superficial ou metamorfismo incipiente. Posteriormente, a porosidade e a permeabilidade são reduzidas devido às mudanças nos minerais e no volume interno.

Porosidade vacular: Rochas carbonáticas são sensíveis ao contato com soluções, tanto durante a fase de diagênese, quanto pós-diagênese. A dissolução de rochas carbonáticas pode resultar na formação de cavernas, dissolução granular ou de componentes fósseis da rocha original. Essa dissolução corresponde à porosidade vacular (secundária) da rocha, podendo melhorar o potencial de reservatório original, pois aumenta o espaço de armazenamento devido ao aumento de porosidade. No entanto, a porosidade vacular de carbonatos pode ser posteriormente perdida devido à infiltração mineral que ocorre com a precipitação de soluções tardias.

Fraturamento: Rochas, tanto cristalinas quanto sedimentares, podem ter seu potencial de reservatório aumentado devido a presença de fraturas. O fraturamento está relacionado a stress tectônico regional e ocorre em padrões específicos, os quais podem ser explorados nos programas de recuperação. Todavia, as fraturas devem ser suficientemente desenvolvidas para permitir o a transmissão de fluidos através da rocha. A pressão de soterramento frequentemente causa fraturas que se fecham em profundidade. Quando isso acontece, o produtor pode usar fraturamento hidráulico para reabrir e manter as passagens de fluido em comunicação com as fraturas naturais já existentes (técnica abordada em detalhes posteriormente na dissertação). Estas aberturas permitem a passagem de fluidos, mas também podem impedi-los. Portanto, o conhecimento do fraturamento é essencial às atividades de produção petrolífera.

Cimentação: $O$ cimento intergranular pode ser composto de qualquer material mineral capaz de ser distribuído através de um meio granular, não-cimentado e poroso. A cimentação pode corresponder a um processo diagenético, e à precipitação de material mineral nos espaços intergranulares a fim de manter os grãos unidos. A quantidade de cimento determina quanto de porosidade e de permeabilidade foram reduzidas, devido a compactação de material nãocimentado. A cimentação pode ser parcial ou completa. Quando a cimentação é completa, a rocha não possui potencial para reservatório, a menos que solução e dissolução de cimento secundária, ou haja crescimento de grãos. Por outro lado, a quantidade e o tipo de cimento podem induzir o fraturamento da rocha, podendo aumentar sua porosidade.

Tipo de reservatório: Os reservatórios são formados sob diferentes condições, as quais resultam em diferentes tipos de rocha, tamanho e forma dos grãos. Estas diferenças fazem com 
que os reservatórios não possam ser explorados a partir de um único conjunto de técnicas, sendo essencial o estudo para se determinar as características gerais de cada tipo de reservatório e as respectivas técnicas mais adequadas à exploração. Reservatórios de hidrocarbonetos são geralmente de natureza clástica ou carbonática. Os reservatórios clásticos mais comuns consistem de arenitos e conglomerados compostos de quartzo, feldspato e uma pequena quantidade de grãos minerais pesados. Em geral, estes grãos são bem maduros, bem arredondados e bem selecionados, devido a sua resistência à destruição mecânica e química. A partir dessas características, rochas clásticas apresentam boa porosidade e permeabilidade e, em geral, se comportam como excelentes reservatórios. Rochas carbonáticas também apresentam grande potencial reservatório, sendo este comparativamente maior que reservatórios clásticos, no entanto sua ocorrência é menos comum.

Tamanho do reservatório: Os programas de recuperação de petróleo envolvem intervalos de espaçamento entre e de perfuração dos poços adequados, os quais estão relacionados ao conhecimento do tamanho do reservatório. Estruturas geológicas que ocorrem como reservatórios são funções diretas dos seus ambientes deposicionais e do tempo em que persistiram as condições adequadas de sedimentação, transporte, etc. O conhecimento da relação entre os fatores geológicos e a estrutura do reservatório gera informações dimensionais que podem ser utilizadas para o espaçamento adequado de poços, e da estabilização de zonas que serão perfuradas para se atingir o máximo na produção de petróleo e gás.

Pressão de fluidos: A carga das camadas superiores (pressão de soterramento), gás em solução e água meteórica são as razões para o desenvolvimento da pressão em reservatórios. Quando um reservatório está em produção, a pressão interna do sistema é reduzida e as fases de fluido são alteradas, alterando também as taxas de produção iniciais. Estas taxas de produção podem ser alteradas por diversos fatores que envolvem tanto os fluidos quanto os reservatórios. À medida que a pressão do reservatório é reduzida, o gás em solução se separa da fase líquida (óleo). A pressão em que esse fenômeno ocorre é denominada ponto de gaseificação. A razão entre volume de gás produzido e o de petróleo produzido é chamada de razão gás-óleo. À medida que a pressão do reservatório diminui a razão gás-óleo aumenta até que todo o gás seja esgotado. As pressões de reservatório inicialmente são suficientes para forçar os fluidos até a superfície. Quando a pressão do reservatório cai, devido a produção, o gás dissolvido no óleo é liberado formando uma fase gasosa. À medida que a expansão ocorre, os fluidos que 
permanecem no reservatório são rapidamente conduzidos em direção à superfície concomitantemente ao rápido declínio da pressão.

\subsubsection{ROCHA SELANTE}

Uma vez migrados para o interior de um reservatório, os fluidos petrolíferos devem encontrar condições que impeçam a continuidade do processo de migração. Normalmente, esta condição é provida por camadas rochas de baixa permeabilidade, situadas acima de rochas reservatório, aprisionando o petróleo e resultando em uma acumulação petrolífera: essas rochas são denominadas selantes, sendo de granulometria fina (folhelhos, siltitos, calcilutitos) ou qualquer rocha caracterizada por baixa permeabilidade, cuja transmissibilidade de fluidos seja inferior à dos reservatórios. Eventualmente, mudanças faciológicas ou diagenéticas dentro da própria rocha reservatório, ou mesmo elementos estruturais tais como falhamentos, ou diferenças entre pressões de fluidos, poderão também servir de selo para o petróleo (Link, 1996).

\subsection{Processos}

\subsubsection{GERAÇÃO}

O petróleo é gerado a partir da quebra das moléculas de querogênio na rocha geradora em decorrência do aumento da temperatura atuante em determinado tempo. Altas temperaturas (idealmente entre 110 a $150{ }^{\circ} \mathrm{C}$ para óleo, ou até $180^{\circ} \mathrm{C}$ para gás) induzem a maturação e a expulsão de petróleo, que depois sofre movimentação ascendente por empuxo, quando em condições hidrostáticas, ou por flutuação associada ao fluxo de fluidos em condições hidrodinâmicas, representando o estágio de migração primária (Link, 1996).

Segundo Rostirolla (1999), quando a saturação em óleo residual alcança 0,5\% a 4\%, as forças de empuxo e a pressão interna condicionam a movimentação de hidrocarbonetos. A saturação é sempre maior no topo do que na base da camada e depende do ângulo de mergulho, viscosidade, taxa de suprimento de hidrocarbonetos e permeabilidade. A ausência de geração configura uma condição restritiva ao funcionamento do sistema petrolífero. No entanto, mesmo que uma rocha contenha matéria orgânica, esta não representa necessariamente uma variável indicativa do fator geração. Para que assim seja, a mesma deve reunir condições adequadas de geração, para o modelo de sistema petrolífero considerado, sendo essencial a presença dos três requisitos: quantidade de matéria orgânica, qualidade da matéria orgânica e maturação. A expulsão de hidrocarbonetos da rocha geradora ocorre quando a saturação em folhelhos (fração 
da microporosidade ocupada por hidrocarbonetos) excede 10-20\%. Normalmente, a eficiência de expulsão aumenta com o aumento da maturidade, alcançando 80 a $90 \%$ para rochas ricas e maturas. Em processos de sobrepressão de fluidos, a expulsão do petróleo pode se dar por fraturamento hidráulico, como no caso da exploração não convencional de hidrocarbonetos.

Os principais critérios utilizados para caracterizar as variáveis indicativas de geração são baseados principalmente em no teor de carbono orgânico total (COT), ou medida relativa do carbono presente na forma de querogênio e betume, além da combinação e relação entre o teor de hidrocarbonetos já presentes na rocha, hidrocarbonetos gerados na rocha (a partir da quebra de querogênio em elevadas temperaturas), e componentes voláteis $\left(\mathrm{CO}_{2}\right.$ e $\left.\mathrm{H}_{2} \mathrm{O}\right)$. Rostirolla (1999) também considera, além da quantidade e qualidade da matéria orgânica, a capacidade volumétrica da rocha geradora.

\subsubsection{MIGRAÇÃO}

Uma vez gerado o petróleo, ele passa a ocupar um espaço/volume maior do que o querogênio original na rocha geradora. Esta se torna supersaturada em hidrocarbonetos e a pressão excessiva dos mesmos faz com que a rocha-fonte se frature intensamente, permitindo a expulsão dos fluidos para zonas de pressão mais baixa. O escoamento dos fluidos petrolíferos, através de rotas diversas pela subsuperfície, até à chegada em um local portador de espaço poroso, selado e aprisionado, apto para armazená-los, constitui o fenômeno da migração. As rotas usuais em uma bacia sedimentar são fraturas em escalas variadas, falhas e rochas porosas diversas, ligando as fontes de geração, profundas e sob alta pressão, a regiões focalizadoras de fluidos, mais rasas, com pressões menores (Rostirolla, 1999).

A migração corresponde à movimentação do petróleo, que ocorre quando a pressão de fluidos excede a pressão capilar, restritiva ao fluxo. As rotas de migração se comportam como um conduto, instalando diferentes gradientes de pressão e permitindo a movimentação do fluido. De acordo com Rostirolla (1999), a tendência de ocorrer migração a partir de falhas e fraturas é menor do que ao longo de camadas. $\mathrm{O}$ autor afirma que a permeabilidade tectônica é menos eficaz que a permeabilidade sedimentar. Entretanto, o fator principal que influencia na migração é o gradiente de pressão, além da facilidade de convergência de fluxo, fatores que podem gerar situações atípicas à migração. $\mathrm{O}$ conceito de migração é cientificamente aceito, no entanto, não há concordância total entre autores quanto aos mecanismos envolvidos e as distancias percorridas. A partir de convenções e de definições de Link (1996), pode-se concluir que existem três diferentes tipos de migração: 
Migração Primária: Quando o petróleo se desloca da rocha fonte para a rocha reservatório. Migração Secundária: Quando o petróleo se movimenta no interior da rocha reservatório após sua acumulação.

Migração Terciária: Ocorre quando o petróleo não fica armazenado e continua a se movimentar em busca de zonas de menor pressão. O petróleo termina como exudação, oxidado ou sofrendo degradação bacteriana.

\subsubsection{ACUMULAÇÃO}

Uma vez em movimento, os fluidos petrolíferos são dirigidos para zonas de menor pressão, normalmente posicionadas em situações estruturalmente mais elevadas que as vizinhanças. As configurações geométricas das estruturas das rochas sedimentares que permitem a focalização dos fluidos migrantes nos arredores para locais elevados, que não permitam o escape futuro destes fluidos, obrigando-os a lá se acumularem, são denominadas de trapas ou armadilhas (Link, 1996).

Elas podem ser simples como o flanco de homoclinais ou, mais comumente, como o ápice de dobras anticlinais/arcos/ domos salinos, ou até situações complexas como superposição de dobras e falhas de natureza diversas. Este tipo de aprisionamento, em uma estrutura elevada, é denominado de trapeamento estrutural. Entretanto, nem sempre o petróleo é aprisionado sob condições estruturais. Eventualmente, a migração do petróleo pode ser detida pelo acunhamento da camada transportadora ou bloqueio da mesma por uma barreira diagenética ou de diferente permeabilidade, ficando então retido em posições estruturalmente não notáveis. Neste caso, teremos um trapeamento de caráter estratigráfico (Milani, 2001).

O entendimento das características a respeito da deposição e da integridade da rocha selante é fundamental para se entender os locais propícios para a acumulação de petróleo. A presença (ou ausência) do selo como variável indicativa exige a existência adequada das seguintes propriedades físicas: capilaridade (pressão mínima que suporta a força de flutuação do fluido), continuidade lateral (geometria e arquitetura de fácies), litologia (ocorrência de halita, anidrita, folhelhos, carbonatos ou chert), ductilidade (tendência da rocha fluir e responder plasticamente durante a deformação), espessura (manutenção das características deposicionais ao longo do tempo e taxa de sedimentação). A trapa é, portanto, uma entidade geológica que integra uma rocha reservatório com forma, capacidade volumétrica adequada e um selo efetivo. O volume de óleo e gás preservado depende da predição do tamanho e tipo da 
trapa que, em conjunto com a migração, constitui o fator com maior influência no sucesso geológico. Dessa maneira, as trapas podem ser classificadas em estruturais, estratigráficas e hidrodinâmicas, sendo nas trapas estratigráficas onde a maioria dos recursos é encontrada (Link, 1996).

Durante as últimas décadas, a exploração e produção de petróleo têm passado por significativos avanços, não apenas tecnológicos, como os relacionados a tecnologias de perfuração, mas também em relação ao conceito de sistemas petrolíferos: atualmente, em virtude de fatores econômicos e da relação oferta e crescente demanda por recursos energéticos, diferentes conceitos de sistemas petrolíferos foram implantados e analisados acerca de seu potencial para hidrocarbonetos. Nesse contexto, o petróleo passou a ser explorado a partir de sequências que antes não apresentavam significância ou viabilidade econômica para exploração. Estes são os chamados sistemas petrolíferos não convencionais, que vêm estabelecendo uma nova fronteira exploratória no Brasil e no mundo.

\subsection{Sistemas Petrolíferos Convencionais}

O conceito de sistemas petrolíferos convencionais é correspondente à definição de sistemas petrolíferos proposta por Magoon \& Dow (1994), a qual engloba presença dos elementos rocha geradora, reservatório e selante, concomitantes e síncronos à ocorrência dos processos de geração, migração e acumulação de hidrocarbonetos. Nesses sistemas ditos convencionais, a produção dos hidrocarbonetos acumulados pode ser realizada por meio da tecnologia disponível, sem necessidade de mecanismos específicos para essa recuperação (o petróleo produzido é extraído pelo poço por meio de diferença de pressão). De modo geral, para essa produção convencional faz-se emprego de recuperações primárias e secundárias e suas taxas de recuperação variam entre 30 a 40\%. Reservatórios convencionais são caracterizados por sua boa porosidade e permeabilidade, baixa viscosidade e interface com água identificável. Em sua maioria são arenitos e calcarenitos (das Virgens, 2011).

\subsection{Sistemas Petrolíferos Não Convencionais}

Sistemas petrolíferos não convencionais são aqueles em que os fluxos normais de produção não são considerados economicamente viáveis (Figura 6). Aqui estão incluídos reservatórios em que há necessidade de estimulação maciça, visto que a produção a partir desses reservatórios processos requer técnicas especiais de recuperação, tais como tecnologias de injeção de vapor ou de faturamento hidráulico; em virtude de sua baixa taxa de recuperação (inferior a $20 \%$ segundo técnicas exploratórias convencionais). Reservatórios não 
convencionais são exemplificados por: gás em estratos de baixa permeabilidade (tight gas ou basin centered gas - BCG), metano em estratos de carvão (coal bed methane - CBM), óleos pesados e gás em folhelho (shale gas) (Yergin, 2011).

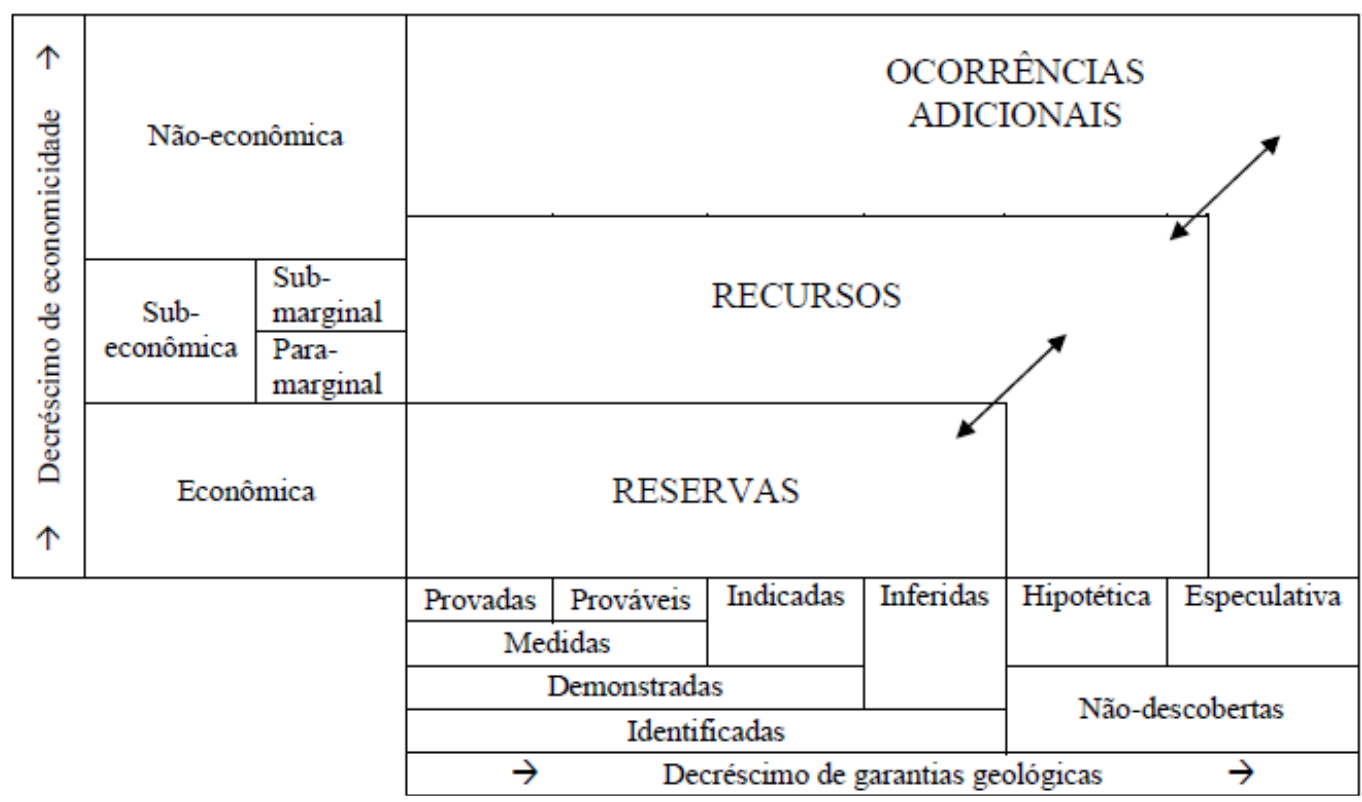

Figura 6 - Classificação de recursos minerais em função de fatores geológicos e econômicos. Fonte: Malagueta (2009).

Quando o volume dos reservatórios é parcial ou totalmente estimado e há tecnologia de extração, estes recursos podem ser denominados de Reservas Técnicas ou Reservas Tecnicamente Recuperáveis, o que significa que a existência do recurso é reconhecida e que há tecnologia para extração. Todavia, enquanto não houver o desenvolvimento das reservas, perfuração de poços e produção, as reservas não serão classificadas como provadas, prováveis ou possíveis (das Virgens, 2011).

É possível que devido à baixa permeabilidade da geradora ou da formação como um todo, que os produtos gerados durante a catagênese (petróleo e/ou gás natural) não entrem em migração secundária havendo, na realidade, uma migração primária parcial. Se isso ocorre, a seguinte situação é possível: a rocha geradora apresenta baixa permeabilidade a ponto de diminuir drasticamente a migração primária $(<0,1 \mathrm{mD})$ (Tabela 1). É possível que nessa situação já tenham sido gerados óleo em folhelho (primeiro) ou gás em folhelho (segundo), sendo o gás natural a fase gasosa do petróleo. A geradora passa então a ser também reservatório e migração restrita à mesma rocha. Aqui, todos os elementos do sistema petrolífero estão presentes em escala reduzida, porém a migração não se deu de geradora para reservatório. Esse tipo de sistema petrolífero é classificado como não convencional (Malagueta, 2009). 
Tabela 3 - Comparação (em mD) entre permeabilidades de reservatórios convencionais e não convencionais (gás em folhelho e coalbed methane-CBM).

\section{Comparação entre Permeabilidades (mD)}

\begin{tabular}{lc}
\hline Gás em folhelho & $<0,1$ \\
CBM & $>0,1 \leq 50$ \\
Rochas reservatórios & $\geq 100 \leq 10.000$ \\
(siliciclásticas e carbonáticas) & \\
\hline
\end{tabular}

Fonte: Modificado de Malagueta (2009).

Todavia, o mais comum é que haja geração, migração-acumulação de petróleo, mas em uma formação geológica que difere das circunvizinhas por barreiras litológicas regionais laterais e verticais, incluindo as rotas de migração. Uma mesma bacia pode ter diversos sistemas petrolíferos como esses, que recebem a denominação de Sistemas Petrolíferos Independentes (SPI) (Magoon \& Dow, 1994) ou sistemas petrolíferos não convencionais. Magoon \& Dow (op.cit) afirmam que para cada bacia explorada pode haver em torno de três ou quatro SPIs. Contudo, como mencionado anteriormente, acumulações de hidrocarbonetos em folhelho apresentam os elementos de um sistema petrolífero, porém em escala reduzida, especialmente no que diz respeito à migração (migração primária). Sob esta ótica, a aplicação do conceito de sistemas petrolíferos independentes de Magoon \& Dow (1994) passa a ser válida ou coincidente para essas acumulações de petróleo em folhelhos, classificando-os como sistemas petrolíferos não convencionais o independentes.

\section{PETRÓLEO NÃO CONVENCIONAL}

\subsection{Histórico}

Desde o início do século XXI, um medo ameaça o setor energético mundial e, consequentemente, a estabilidade econômica global: o medo do fim do petróleo. O petróleo consiste em um combustível finito e não renovável, se considerado na escala de tempo da humanidade, e tem sido responsável por financiar o significativo crescimento econômico e populacional do século. O medo de que as reservas petrolíferas estariam chegando ao fim surgiu com a teoria peak oil (pico de óleo), proposta por M. King Hubbert ${ }^{2}$ em 1956 e fundamentada

\footnotetext{
${ }^{2}$ Geólogo americano associado à Shell Oil Company durante a década de 1950. Ao longo de sua experiência de trabalho concluiu que as descobertas de reservas petrolíferas que, quando representadas graficamente, assumiam
} 
na ideia de que o ápice da exploração petrolífera já havia sido atingido. Portanto, as reservas estavam em esgotamento, pois a produção atingiria o ápice. A teoria representa a produção petrolífera mundial graficamente por um pico (ou sino), o qual corresponde à máxima explotação devido à crescente demanda, fase dos dias atuais ou prestes a ter início, seguida de um inevitável declínio na produção devido o esgotamento do recurso. No entanto, a teoria do peak oil não considera perspectivas de avanço tecnológico e de conhecimento científico, fatores decisivos neste cenário por serem capazes de garantir décadas de produção até se tenha início um declínio, o qual seria muito menos abrupto diante destas circunstancias. Inovações no setor petrolífero geram controvérsias no modelo de peak oil, e indicam a representação da produção como um platô, i.e., o ápice da exploração pode ser prolongado conforme o indicado na Figura 7, adiando o declínio por esgotamento de reservas, o qual seria muito mais gradual e menos impactante ao mercado (Yergin, 2011).

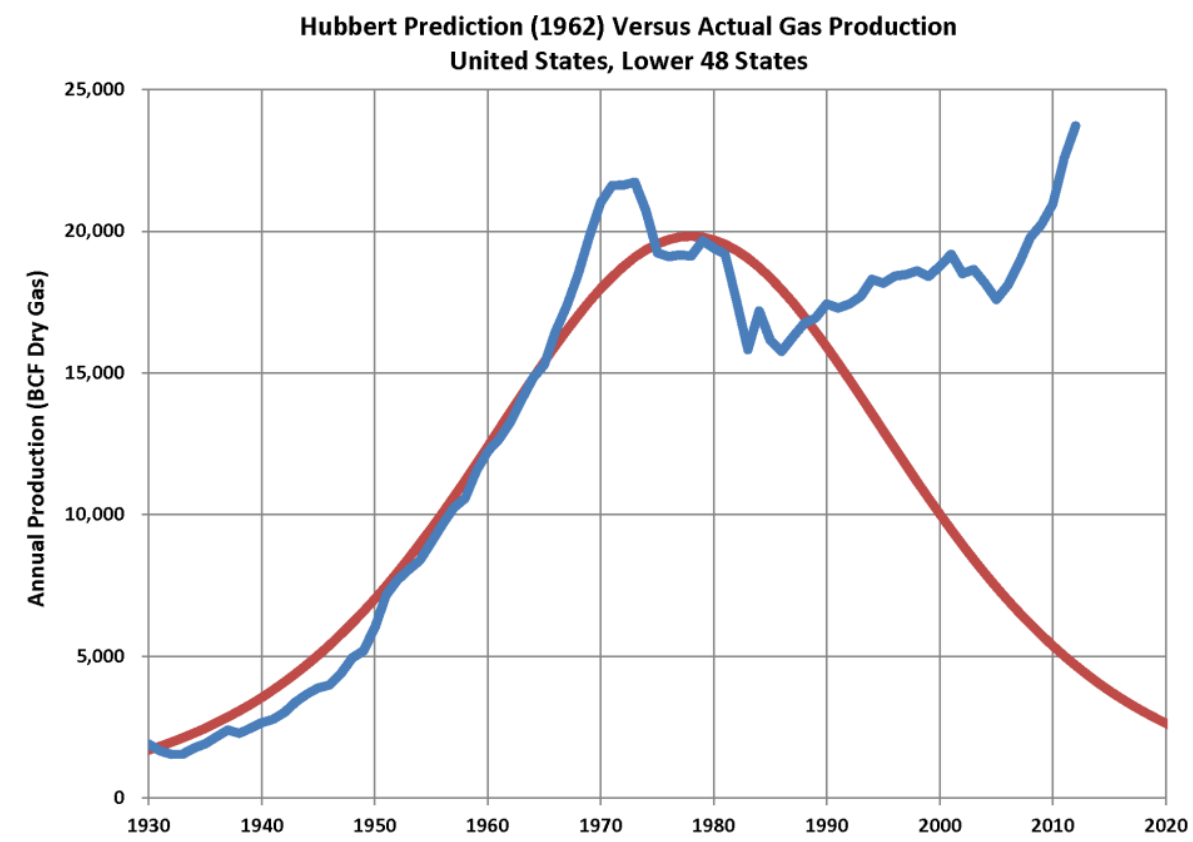

Figura 7 - Representação esquemática de previsão de Hubbert realizada em 1962 para a produção de óleo e gás natural de 48 estados americanos (em vermelho), versus a produção ocorrida em 2012 (em azul). Fonte: Modificado de Hubbert, (1962), apud "Energy Resources," National Academy of Sciences, Publication 1000-D, p.81-83.

a forma de sino, assim como as curvas referentes à produção desse recurso. A partir destas observações, estabeleceu a teoria de peak oil, afirmando que o setor petrolífero atingiria um pico de exploração e produção seguido de um abrupto declínio de produtividade em virtude do esgotamento desse recurso. Em 1962, Hubbert previu que a produção de 48 estados americanos atingiria seu pico entre 1965 e 1970, informação a qual, apesar de sua baixa credibilidade, teria se concretizado. Todavia, este teria sido posteriormente justificado pela escassez de tecnologia e informações a respeito de novas reservas ao invés do esgotamento do recurso fóssil. Adaptações modernas da teoria de Hubbert sugerem a forma de platô para a representação desse cenário, enquanto que outros pesquisadores afirmam que o pico representa o fim da produção economicamente acessível e que pode ser aplicável em diferentes momentos da sociedade, como o caso de recursos petrolíferos não convencionais. 
Segundo Yergin (2011), apesar de parecer recente, o medo do fim do petróleo já esteve presente na história mundial, sempre associado à crescente demanda por esse recurso. Iniciada por Edwin Drake no norte da Pensilvânia, a indústria moderna do petróleo tem enfrentado desafios em atender o equilíbrio entre oferta e demanda durante décadas. Inicialmente utilizado como fonte de iluminação a fim de substituir o óleo de baleia, o petróleo se tornou essencial à sociedade desde 1859. A partir de então, a demanda pelo combustível cresceu abruptamente com o desenvolvimento da indústria automobilística, bélica, entre outras, a fim de suprir o crescimento acelerado de economias emergentes (Figura 8). Neste contexto, a indústria do petróleo passou por crises, resultando em aumento de preços e ameaçando a estabilidade econômica mundial em diversos períodos da história, crises as quais teriam sido amenizadas ou solucionadas a partir de pesquisas e avanços tecnológicos que garantissem a produção. A situação atual não seria diferente, será que o petróleo estaria mesmo chegando ao fim, ou falta tecnologia para continuar a explorá-lo?

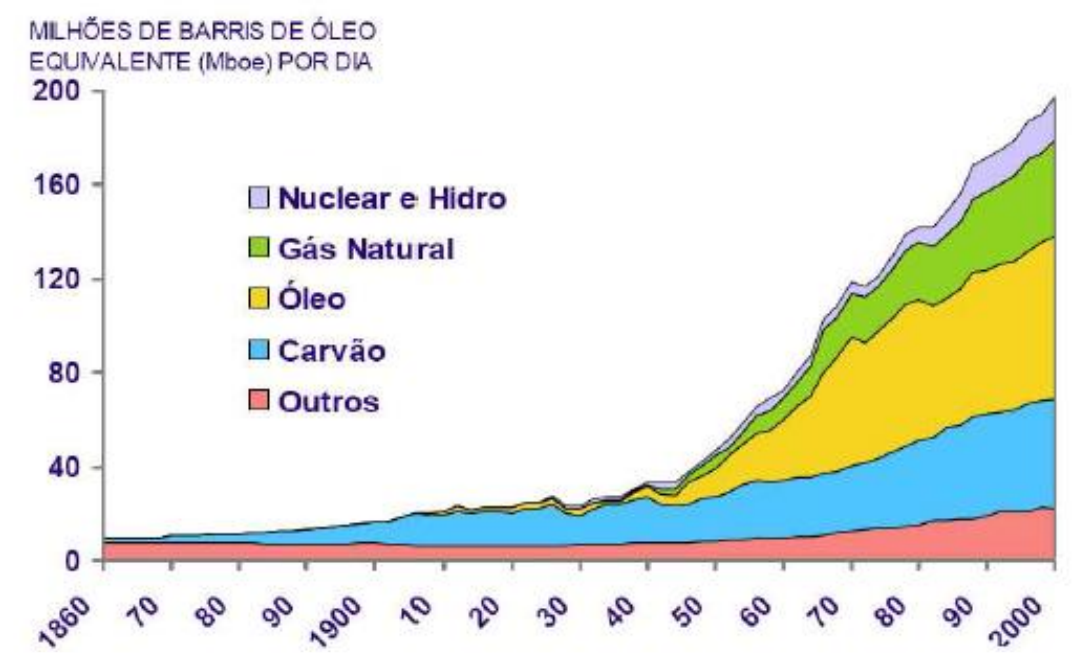

Figura 8 - Gráfico representativo do consumo mundial de energia primária desde a 1860 a 2000. Fonte: IEA (2007) apud. Malagueta (2009).

A história das indústrias de óleo e gás está fortemente vinculada a avanços tecnológicos. Novas tecnologias têm sido desenvolvidas com a finalidade de se identificar novas reservas e também de se produzir a partir de campos já explorados. Sabe-se que, geralmente, em campos de petróleo menos de $60 \%$ da acumulação pode ser produzida por meio de métodos tradicionais (Yergin, 2011). Diante dessa situação, pesquisas têm sido desenvolvidas para aumentar essa taxa de recuperação, baseadas não apenas em tecnologias de exploração, mas também em estudos de fontes de petróleo não convencionais.

\subsection{Cenário Atual}


Existem diferentes fontes não convencionais de óleo e gás natural. Mesmo que a ocorrência desses tipos de acumulações já tenha sido reconhecida há décadas, o desafio está em encontrar técnicas de recuperação desse recurso em escala comercial.

Estudos referentes à geologia de petróleo têm se divido em dois ramos de pesquisa de hidrocarbonetos: convencionais e não convencionais. Estes representam diferentes processos de acumulação e caracterização de reservatórios, conforme abordado anteriormente no capítulo; além de corresponder ao novo destaque na teoria e conceitos da geologia de petróleo. O estudo geológico de hidrocarbonetos convencionais tem como foco identificar a relação entre rochas fonte, reservatório e selante e sua associação com os processos de migração, trapeamento, acumulação e contemporaneidade. Já o foco de estudo da geologia de hidrocarbonetos não convencionais está na avaliação da continuidade do processo de acumulação do petróleo, associada à análise litológica, estrutural e das propriedades físicas atuantes no processo (Zou, et.al. 2013).

De acordo com a Agência Internacional de Energia (International Energy Agency IEA, 2012), estão inclusos no conceito de hidrocarbonetos não convencionais: gás e óleo em folhelho, areias betuminosas, óleos sintéticos e produtos derivados, gás e óleo gerado a partir de carvão mineral e biomassa, além de incluir hidrocarbonetos em diferentes níveis de maturação como querogênio, óleos pesados e condensados.

A novidade no setor de gás natural é o chamado Shale Gas: gás natural não convencional gerado e aprisionado em folhelhos em decorrência de sua permeabilidade reduzida. Esse tipo de acumulação tem se destacado dentre as fontes energéticas não convencionais devido seu potencial em apresentar elevadas concentrações de gás natural e por sua ampla distribuição geográfica. A exploração, que anteriormente se mostrava economicamente inviável, se tornou possível devido o desenvolvimento tecnológico: técnicas como o faturamento hidráulico e a perfuração horizontal tornaram possível a exploração desse recurso e tem trazido significativo retorno econômico.

Juntamente com outras fontes não convencionais de petróleo e gás, o gás em folhelho vem representando uma nova fronteira exploratória, diferente da tradicional produção convencional, mas que pode gerar impacto significativo na economia mundial. De acordo com Yergin (2011), essa nova definição de fontes de petróleo tem se expandido e ajudado a suprir a crescente demanda da sociedade por recursos energéticos. Yergin (op.cit.) acredita que até 2030, essas fontes não convencionais serão a base da produção petrolífera norte americana e receberão uma nova denominação: convencionais. 


\subsection{Experiência Norte-Americana}

A constante busca por recursos energéticos tem resultado em diversos avanços no setor de hidrocarbonetos não convencionais. Pesquisas realizadas pelo U.S.Geological Survey (Serviço Geológico dos Estados Unidos) constataram que gás natural não poderia ser apenas explorado em reservatórios de configuração convencional, como, por exemplo, em trapas anticlinais, mas também poderia ser encontrada em rochas de baixa permeabilidade. Uma propriedade que confere simultaneamente, ao mesmo pacote rochoso, o papel de reservatório e selante. A descoberta revolucionou a indústria petrolífera dos Estados Unidos, mas ainda havia de enfrentar diversas dificuldades em seu processo de exploração: não se havia conhecimento a respeito das técnicas necessárias à explotação desse recurso, resultando em elevados custos com pesquisas e implementação de novas tecnologias (Yergin, 2011).

As principais técnicas de exploração de sistemas não convencionais foram desenvolvidas nos Estados Unidos a partir de estudos sobre a produção feitos no folhelho Bakken $^{3}$ e são denominadas fracking e horizontal drilling. O termo fracking refere-se à técnica de faturamento hidráulico, que vem sendo utilizada desde 1940 e consiste, basicamente, na injeção de grande volume de água sob alta pressão, em associação com areias e compostos químicos, à uma formação geológica saturada em petróleo. Tem por objetivo fraturar a rocha em questão a fim de gerar uma rota de passagem para o fluido explorado. Outra técnica de exploração, denominada perfuração horizontal, emergiu na década de 1980. Os avanços tecnológicos permitiram que operadores perfurassem até certas profundidades e em seguida, passassem a realizar uma perfuração em ângulo, ou até mesmo completamente horizontal. Essa técnica permitiu um maior acesso ao reservatório, resultando em maior recuperação de gás (ou óleo). A partir desse conhecimento adquirido, empresas passaram a combinar ambas as técnicas de perfuração, trazendo inovação ao mercado e grande retorno financeiro. No entanto, esse retorno financeiro pode vir associado a altos custos ambientais: a exploração desse recurso requer o uso da técnica de faturamento hidráulico, que inclui a injeção de milhões de litros de água misturada a compostos químicos que, potencialmente, podem resultar na contaminação de aquíferos (Yergin, 2011).

A combinação entre o avanço tecnológico do faturamento hidráulico e a perfuração horizontal revolucionou o mercado e ficou conhecida por Yergin (2011) como a Revolução do Gás Não Convencional, fazendo conhecidos recursos como os denominados shale gas, coalbed methane (CBM) e tight gas; basin centered gas (BCG), os quais correspondem,

\footnotetext{
${ }^{3}$ Bacia Williston, Devoniano-Mississipiano,abrangendo a parte central dos EUA até o Canadá.
} 
respectivamente, aos chamados gás em folhelho, metano em estratos de carvão mineral, e gás em reservatórios de baixa permeabilidade. Com esse avanço tecnológico, o gás natural assou a ter preço competitivo no mercado de recursos energéticos, obtendo vantagens devidas seu menor teor de poluentes em relação aos demais combustíveis fósseis: carvão mineral e óleo e ganhando vantagens também sobre fontes de energia renováveis devido seu menor custo.

\subsubsection{GÁS NATURAL NÃO CONVENCIONAL}

A partir da chamada revolução energética dos Estados Unidos, a exploração de gás natural a partir de fontes não convencionais se popularizou, fazendo com que o mundo reconhecesse essa nova fronteira exploratória e iniciando a internacionalização desse mercado (Yergin, 2011). No Brasil, estudos e cálculos de reservas recuperáveis, realizados pela ANP em 2012, indicam números promissores para o país, com estimativas de 200 trilhões de pés cúbicos de gás (Tcf) apenas em três bacias sedimentares brasileiras: Parecis, Recôncavo e Parnaíba. O presidente do conselho administrativo da consultoria Gás Energy, Marco Aurélio Tavares acredita que essa pode ser a oportunidade para a criação de uma grande indústria nacional de gás natural e de uma forte impulsão no desenvolvimento do Brasil (Petronotícias, 2012).

De modo geral, existem três tipos de acumulações não convencionais de gás natural (Figura 9). A mais conhecida é o chamado gás em folhelho, conhecido também (apesar de erroneamente) como gás de xisto, popularizado pelo recente boom de produção nos EUA. Além deste, existem também o CBM, que consiste em geração de metano a partir de estratos de carvão mineral, e o gás em reservatório de baixa permeabilidade (BCG ou tight gas), característicos de reservatórios de baixa permeabilidade. O que define esses três tipos de acumulações de gás natural como não convencionais, além da baixa permeabilidade, é uma taxa de recuperação média de $20 \%$, que é inferior à média dos chamados reservatórios convencionais, que varia entre 35 a 60\%. Portanto, necessita-se da implantação de diferentes técnicas exploratórias que favoreçam a viabilidade econômica dos depósitos não convencionais (Das Virgens, 2011). 


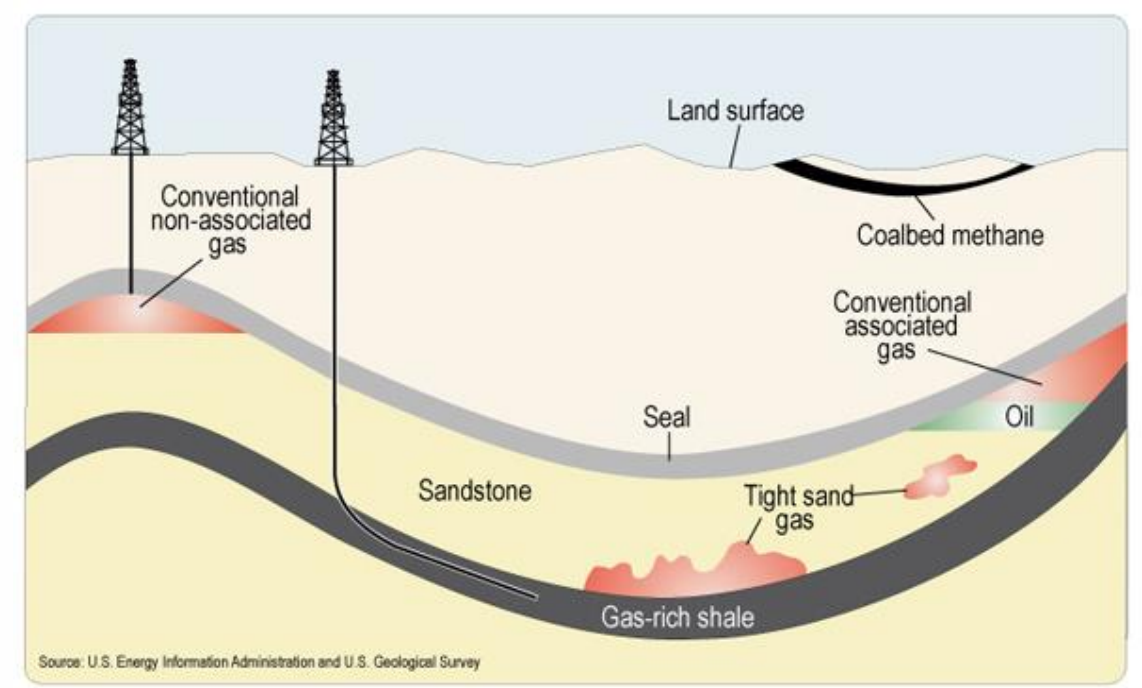

Figura 9 - Representação esquemática dos principais tipos de depósitos de gás natural.

Fonte: U.S. Geological Survey (2012).

No caso do BCG e do gás em folhelho, estes não diferem do gás natural convencional em termos de composição ou origem, mas apenas na forma de ocorrência no reservatório. Em outras palavras, é predominantemente metano, podendo ser tanto de origem termogênica ou biogênica (Law, 2002), conceitos melhor abordados adiante no presente capítulo.

O gás natural corresponde a uma mistura de hidrocarbonetos leves que se apresentam em estado gasoso, denominados como a fase gasosa do petróleo. Tais gases podem se apresentar isolados em um reservatório ou associados a óleo. O principal componente do gás natural é o metano $\left(\mathrm{CH}_{4}\right)$, sendo que em muitos depósitos de gás natural, o teor de metano representa aproximadamente 92 a 95\% da composição total. Diversos processos podem resultar na geração de metano, sendo a maior produção induzia por degradação bacteriana da matéria orgânica. À medida que temperatura do sistema se eleva e o petróleo é consequentemente termicamente alterado, algumas das moléculas constituintes são separadas pelo calor, resultando na formação de metano e de outras pequenas moléculas de hidrocarbonetos. Podese afirmar que, quanto maior a profundidade do sistema, maior a taxa de geração de metano devido às maiores temperaturas. A ação repetida da quebra de moléculas de hidrocarbonetos resulta na formação de cadeias carbônicas cada vez menores e, consequentemente, produzindo maior quantidade de moléculas com carbonos associados (de um a quatro carbonos). Essas moléculas que correspondem ao gás natural, apresentando-se em estado gasoso em pressões e temperaturas ambiente. Dessa maneira, quanto maior a profundidade de perfuração para exploração, maior a tendência de se encontrar petróleo na fase gasosa. A maioria dos depósitos comerciais de gás natural segue esse princípio de formação (Radovic, 1997). 
Além do metano, o gás natural também é constituído por pequenas quantidades de outras moléculas de hidrocarbonetos (Tabela 2); dentre os quais estão inclusos o etano $\left(\mathrm{C}_{2} \mathrm{H}_{6}\right)$, propano $\left(\mathrm{C}_{3} \mathrm{H}_{8}\right)$, e butano $\left(\mathrm{C}_{4} \mathrm{H}_{10}\right)$. Menores quantidades de pentano $\left(\mathrm{C}_{5} \mathrm{H}_{12}\right)$ e hexano $\left(\mathrm{C}_{6} \mathrm{H}_{14}\right)$ também podem ser encontrados. Sob condições normais de pressão e temperatura, pentano e hexano se apesentam no estado líquido, no entanto, quando expostos à elevadas temperaturas decorrente de soterramento, estes podem constituir gases e compor parte do gás natural. Além desses hidrocarbonetos, depósitos de gás natural podem conter componentes inorgânicos, incluindo nitrogênio, hélio, dióxido de carbono e sulfetos hidrogenados (Radovic, 1997).

Tabela 4 - Representação da composição média de gases naturais em relação à moléculas de hidrocarbonetos. Análise baseada em amostras de reservatórios situados na Europa, África e América do Norte.

\begin{tabular}{lccc}
\hline Componente & Vol.(\%) & Componente & Vol.(\%) \\
\hline $\mathrm{CH}_{4}$ & 81,5 & $\mathrm{~N}_{2}$ & 5,2 \\
$\mathrm{C}_{2} \mathrm{H}_{6}$ & 3,6 & $\mathrm{CO}_{2}$ & 4,6 \\
$\mathrm{C}_{3} \mathrm{H}_{8}$ & 2,0 & $\mathrm{H}_{2} \mathrm{~S}$ & 1,4 \\
$\mathrm{C}_{4} \mathrm{H}_{10}$ & 0,4 & - & - \\
$\mathrm{C}_{5} \mathrm{H}_{12}$ & 0,2 & $\mathrm{He}$ & 0,04 \\
$>\mathrm{C}_{5}$ & 1,0 & - & - \\
\end{tabular}

Fonte: Neumann et al (1981) apud. Radovic (1997).

Quanto à origem, o gás natural pode ser classificado em biogênico e termogênico (Figura 10). O gás biogênico é formado em baixas temperaturas e profundidades de soterramento (até no máximo $1.000 \mathrm{~m}$ ), sob condições anaeróbicas ou associadas a elevadas taxas de sedimentação marinha. Cerca de $20 \%$ do gás natural conhecido mundialmente é de origem biogênica. Já o gás termogênico é formado sob mais elevadas condições de temperatura 
e soterramento, sendo formado durante a catagênese média e em baixo grau tardio da metagênese (fase em que o metano termal substitui o metano biogênico) em resultado à alteração do querogênio e de outros constituintes orgânicos a partir de quebra molecular e degradação. O gás termogênico contém quantidades significativas de hidrocarbonetos mais pesados quando comparado ao gás biogênico. À medida que a temperatura sobe, hidrocarbonetos mais leves se formam como gás úmido e condensado nas fases finais da termogênese. O gás úmido e os condensados acompanham a progressão da catagênese seguidos por um metamorfismo de baixo grau (metagênese) e metano termogênico. À medida que o metamorfismo avança o óleo passa a ser eliminado, resultando em uma acumulação exclusiva de gás natural (Tissot \& Welte, 1978).

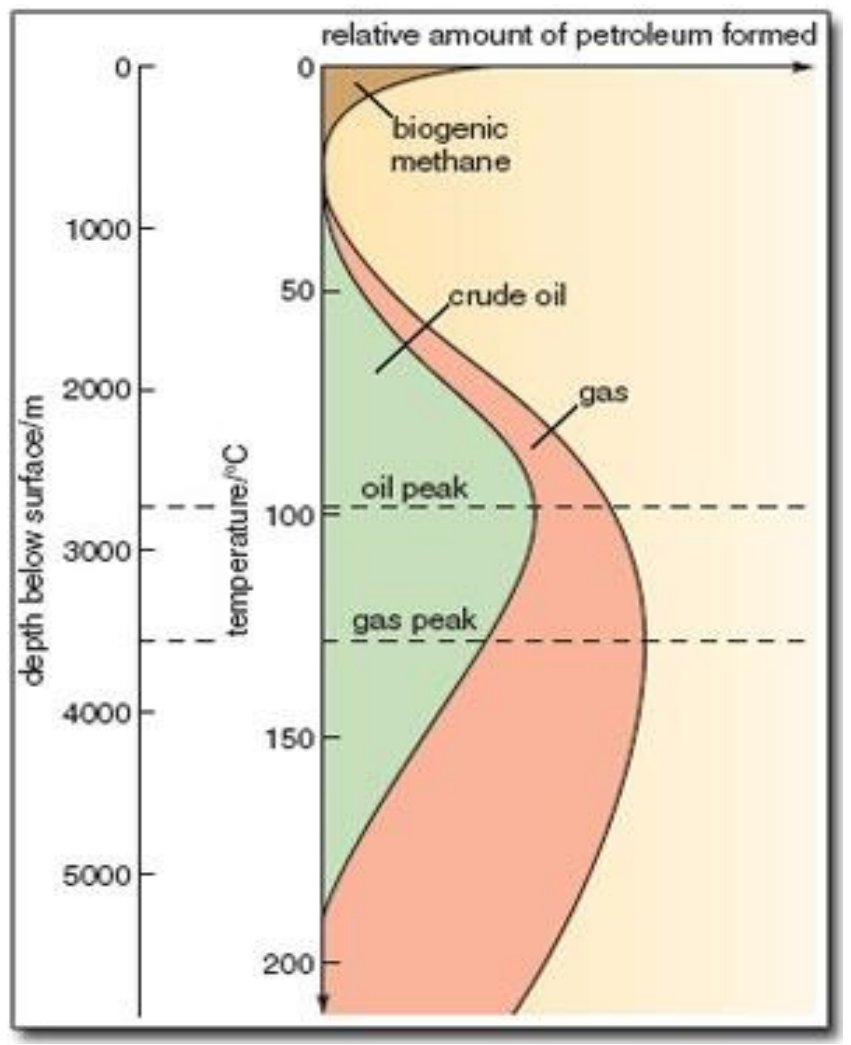

Figura 10 - Representação esquemática da relação entre temperatura e profundidade de soterramento com tipo e quantidade estimada de petróleo gerado. Fonte: Modificado de Tissot \& Welte (1978).

\subsubsection{GÁS EM FOLHELHO (SHALE GAS)}

O termo shale gas ou gás em folhelho corresponde a depósitos de gás natural que se encontram retidos em formações pelíticas (folhelhos). Folhelhos geralmente se caracterizam por sua baixa permeabilidade, fato que dificulta a exploração de petróleo a partir desta litologia, antes considerada fonte não comercial de hidrocarbonetos. No entanto, a permeabilidade 
reduzida dos folhelhos que dificulta a produção de hidrocarbonetos diretamente dessa formação também atua como um fator de retenção de gás natural no interior desse pacote rochoso (entre as lamelas que acompanham a foliação). Folhelhos que contém quantidades significativas de gás natural apresentam as seguintes propriedades em comum: composição enriquecida em matéria orgânica (de 0.5 a 25\%), e geralmente se apresenta no campo de existência de gás termogênico (intervalo de temperatura e soterramento suficientemente elevados, convertendo o petróleo em gás natural - vide figura 10, no intervalo compreendido abaixo do pico de gás (gas peak)) O gás gerado a partir desse processo pode ser contido em fraturas naturais do pacote rochoso, no interior de poros, e/ou adsorvidos ao material orgânico-sedimentar. A recuperação do gás retido em poros e fraturas se dá durante a atividade exploratória, enquanto que o gás adsorvido é liberado à medida que ocorre redução da pressão interna do reservatório (Das Virgens, 2011).

O gás de folhelho foi inicialmente explorado em 1821 na região de Fredonia, em Nova York, a partir de fraturas superficiais em camadas de folhelho negro. Com o desenvolvimento da técnica de perfuração horizontal, por volta de 1930, e de fraturamento hidráulico, em 1947, associado à escassez de petróleo e declínio de produção de gás natural durante a década de 1970, a exploração desse tipo de gás veio a se tornar econômica. Diante do declínio de produção de gás natural, o governo federal americano passou a investir na busca por alternativas, criando o Eastern Gas Shales Project (Projeto de Gás em Folhelho da Região Leste). O projeto teve início em 1976 e consistia no financiamento de pesquisas nesse setor, inicialmente nas bacias Michigan e Apalache, além de parceria industrial, a qual recebia incentivos fiscais do governo que visava iniciar e expandir a produção. Desde então, o gás de folhelho tem sido um importante contribuinte para a geração de energia os EUA. O gás de folhelho também ficou popularmente conhecido como gás de xisto ${ }^{4}$. No entanto, esse termo é erroneamente aplicado: xistos são rochas metamórficas e não são consideradas rochas geradoras de hidrocarbonetos (Yergin, 2011).

\subsection{ASPECTOS GEOLÓGICOS}

O folhelho consiste em uma rocha sedimentar caraterizada por sua granulação fina $(<$ $1 / 256 \mathrm{~mm}$ ) e fissilidade. É predominantemente constituída de minerais argilosos, além de menores frações de quartzo e feldspatos, e matéria orgânica. Essas rochas apresentam elevado

\footnotetext{
${ }^{4}$ Acredita-se que o termo se popularizou devido à bibliografia francesa, onde é referido como gaz de schiste, denominação que gerou a tradução equivocada.
} 
potencial gerador de hidrocarbonetos. No caso de gás de folhelho, a geração e a acumulação de gás natural ocorre in situ, sendo concentrado em fraturas e poros da rocha. Esses folhelhos recebem tripla classificação, sendo considerados rocha geradora, rocha reservatório, e selante de um sistema petrolífero (U.S. Geological Survey, 2012). O processo de migração é bastante limitado (migração primária), percorrendo apenas distâncias muito curtas, dentro de um mesmo pacote rochoso, no caso, o folhelho. Esses folhelhos saturados em gás natural podem também atuar como rochas geradoras de outros sistemas petrolíferos, de disposição superior a essas rochas, onde o fluido irá migrar para outra litologia que exerça o papel de rocha reservatório. De acordo com diversos autores, o principal fator que favorece a concentração desse gás nos folhelhos é o estágio de sobrepressão do sistema, reduzindo a taxa de migração do fluido e resultando em acumulações dentro da própria rocha geradora, que também apresenta características selantes. Além disso, a matéria orgânica presente no sistema (abundante em folhelhos) é capaz de reabsorver moléculas de gás termogênico que se foram geradas a partir desse folhelho, funcionando como trapas para esse gás dentro do próprio sistema (ExxonMobil, 2012).

\subsection{CENÁRIO ATUAL}

O gás de folhelho recentemente se tornou uma importante fonte de gás natural nos Estados Unidos e o interesse por este recurso natural se expandiu internacionalmente. A combinação das técnicas exploratórias de fraturamento hidráulico e perfuração horizontal tornou possível a exploração desse recurso, antes não considerado economicamente viável devido a limitações tecnológicas. Nos anos 2000, a produção de gás em folhelho representava apenas $1 \%$ da produção anual total de gás natural nos EUA, porém, em 2010, chegou a atingir mais de $20 \%$ do total, e de acordo com a Energy Information Administration (EIA), a produção desse recurso atingirá $46 \%$ da produção total de gás em 2035. Atualmente, o gás de folhelho é o recurso não convencional mais explorado mundialmente, e corresponde a mais de $50 \%$ da produção de gás natural não convencional dos EUA. De acordo com estudos e estimativas, o gás natural tem desempenhado um importante papel no setor energético e setor elétrico, correspondendo ao segundo combustível mais consumido atualmente nos Estados Unidos para geração de energia primária e de eletricidade (Figuras 11 e 12) (EIA, 2013). 


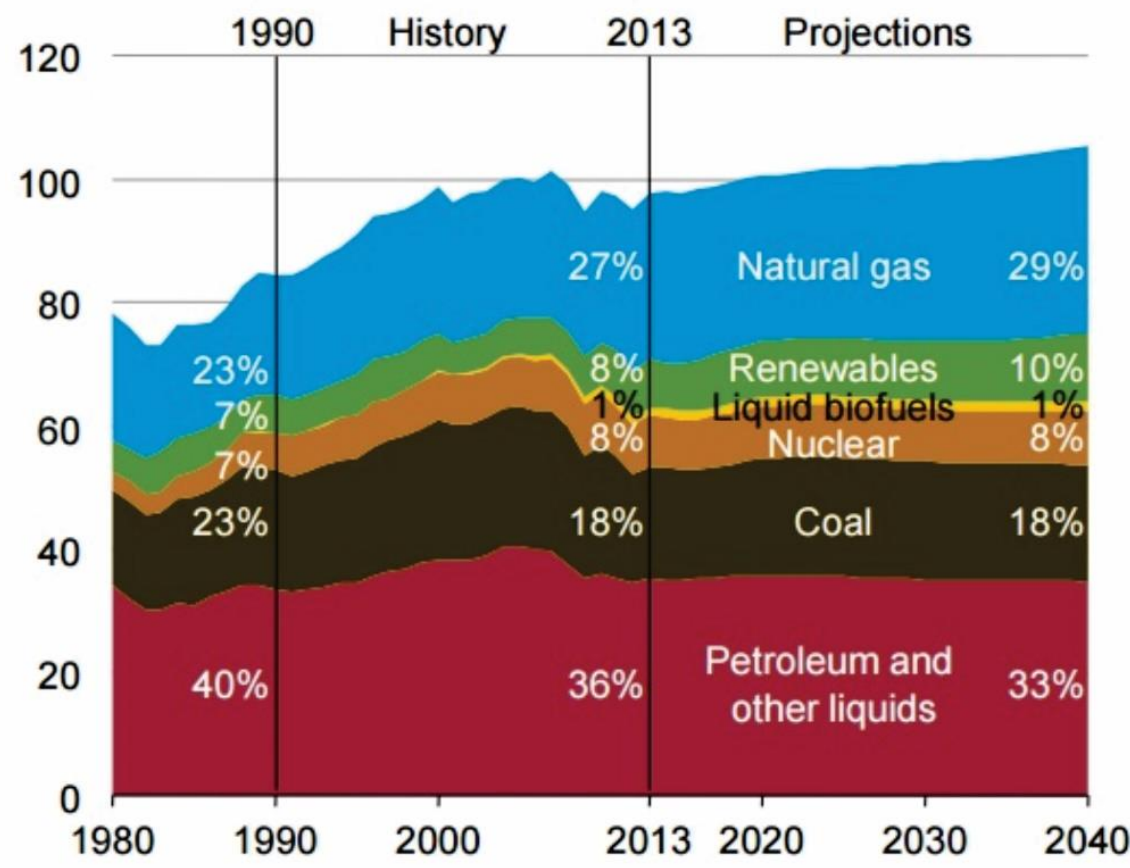

Figura 11 - Projeção gráfica do consumo de energia primária, por combustível, nos Estados Unidos. Fonte: U.S. Energy Information Administration (EIA), 2015.
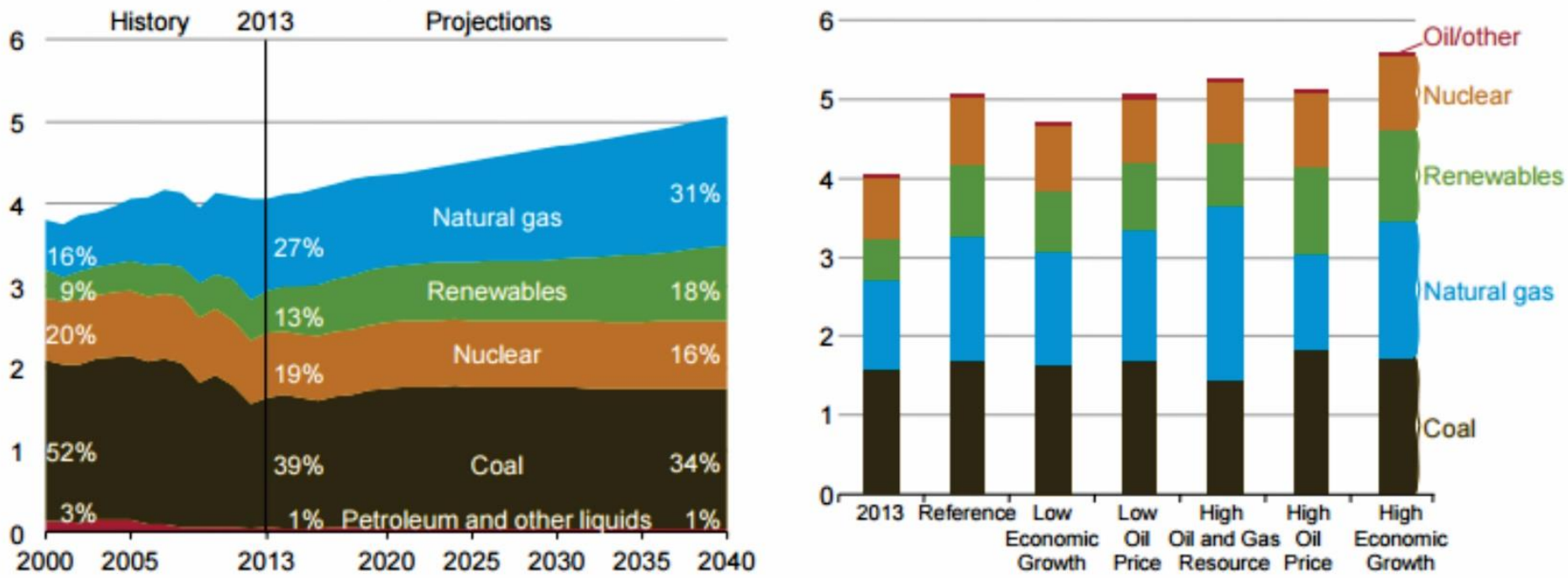

Figura 12 - Projeção gráfica da geração de energia elétrica por combustível, nos Estados Unidos. U.S. Energy Information Administration (EIA), 2015.

O atual presidente dos Estados Unidos, Barak Obama, se pronuncia a favor da exploração de gás em folhelho e afirma que o desenvolvimento desse recurso energético pode ajudar a reduzir a emissão de gases que favorecem o efeito estufa ${ }^{5}$. Estudos recentes indicam

\footnotetext{
${ }^{5}$ As emissões de dióxido de carbono nos Estados Unidos têm sido significativamente reduzidas nos últimos cinco anos (2010-2015). Essas reduções contrastam com as estimativas para emissões de $\mathrm{CO}_{2}$, previstas em 1998 a partir de determinações do Protocolo de Kyoto. Durante o período dessas discussões, a U.S. Energy Information Administration (EIA), havia estimado que as emissões de $\mathrm{CO}_{2}$ teriam um aumento anual sob a taxa de $1.3 \%$ até
} 
que, de modo geral, o uso de gás de folhelho como fonte energética resulta na emissão de menos poluentes do que a produção convencional (Forbes, 2012). No entanto, outros fatores ambientais associados às técnicas de exploração desse recurso, deixam controvérsias a respeito de seus impactos ambientais, tais como a contaminação de aquíferos e corpos hídricos.

2020. Acredita-se que essas estimativas previam aumento da emissão de poluentes por não levarem em consideração a exploração de recursos não convencionais mais limpos, como o caso do gás de folhelho, ainda não significativamente explorado na época. 


\subsection{OCORRÊNCIA}

O gás de folhelho é encontrado em porções de folhelhos que se apresentem saturadas em gás natural com significativas concentrações. Sua produção teve início no chamado Folhelho Barnett, situado no Texas, sendo também significativamente explorado do Folhelho Marcellus, situado na região das Montanhas Apalache, leste dos Estados Unidos (EIA, 2012). Através de dados geofísicos de superfície e subsuperfície, associados a estudos geológicos, outras reservas desse tipo de gás foram encontradas ao longo dos EUA (Figura 13).

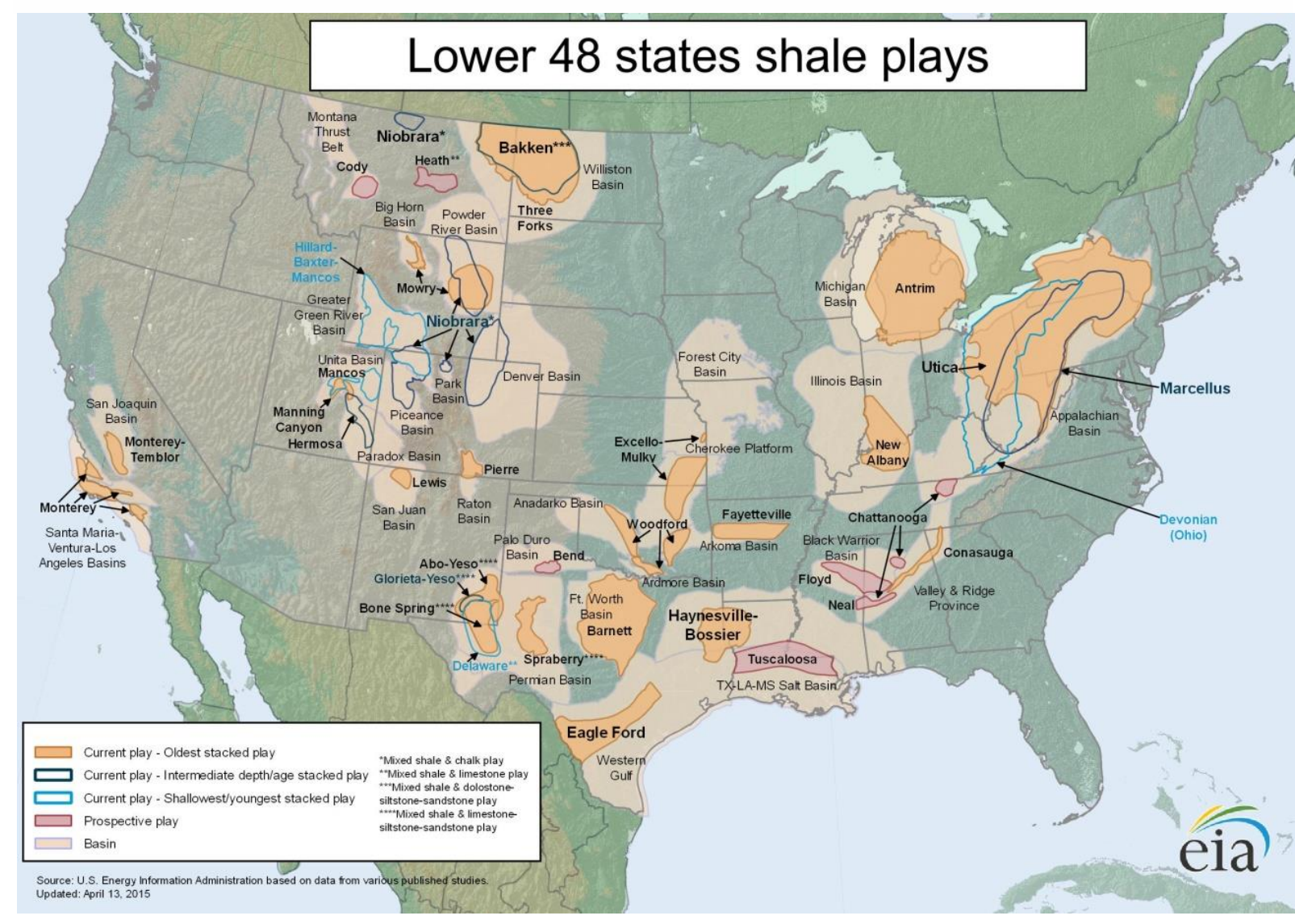

Figura 13 - Mapa das bacias sedimentares norte americanas produtoras de shale gas. U.S. Energy Information Administration (2015).

Fonte:

De acordo com a EIA (2012) e conforme abordado no capítulo I, depósitos de gás de folhelho podem ser encontrados em escala global, sendo que as maiores concentrações estão presentes na China (Tabela 3), com valores estimados em 1.115 Tcf, seguidos por Argentina (802 Tcf), Argélia (707 Tcf), Estados Unidos (665 Tcf), e Canadá (573 Tcf). Apesar de diversas nações apresentarem potencial para a produção de gás de folhelho, até o ano de 2013, apenas os Estados Unidos, Canadá, e China produzem esse recurso em escala comercial. O Brasil está presente em décima posição na lista de países com maior potencial para esse recurso, estimado 
em 245 TCF. No entanto, apenas 14 reservas nacionais tiveram seu potencial comprovado, fato que reflete a insuficiência de pesquisas nacionais nesse setor.

Tabela 3 - Tabela apresentando a distribuição mundial de reservas estimadas e comprovadas de gás de folhelho, organizada de acordo com a ordem de países com maiores potenciais para esse recurso.

\begin{tabular}{|c|c|c|c|}
\hline Colocação & País & $\begin{array}{l}\text { Valores Estimados de } \\
\text { Recuperação (Tcf) }\end{array}$ & $\begin{array}{c}\text { Reservas Naturais } \\
\text { Comprovadas }\end{array}$ \\
\hline $1^{\circ}$ & China & 1.115 & 124 \\
\hline $2^{\circ}$ & Argentina & 802 & 12 \\
\hline $3^{\circ}$ & Argélia & 707 & 159 \\
\hline $4^{\circ}$ & Estados Unidos & 665 & 318 \\
\hline $5^{\circ}$ & Canadá & 573 & 68 \\
\hline $6^{\circ}$ & México & 545 & 17 \\
\hline $7^{\circ}$ & África do Sul & 485 & - \\
\hline $8^{\circ}$ & Austrália & 437 & 43 \\
\hline $9^{\circ}$ & Rússia & 285 & 1.688 \\
\hline $10^{\circ}$ & Brasil & 245 & 14 \\
\hline
\end{tabular}

Fonte: Modificado de U.S. Energy Information Administration, (2013).

Até o presente momento, não existe ainda um modelo para desenvolvimento de gás em folhelho no Brasil. No entanto, já existem dados prévios referentes a estimativas realizadas pela ANP, baseadas em estudos comparativos entre rochas e dados sísmicos com bacias nos Estados Unidos. Esses estudos geram cálculos para volumes recuperáveis nas seguintes bacias brasileiras: Bacia do Parnaíba, Bacia do Recôncavo, Bacia de Parecis (Figura 14), com um total estimado em 245 trilhões de pés cúbicos de gás natural (Tcf) e as bacias do Solimões, de São Francisco e do Paraná, com estimativas não oficiais de 600 Tcf (ANP, 2013). Nesse contexto, acredita-se que o Brasil também apresente grande potencial para essas acumulações não convencionais de gás natural, sendo necessários mais estudos referentes a esse tipo de acumulação a fim de se possa descobrir novas reservas. 


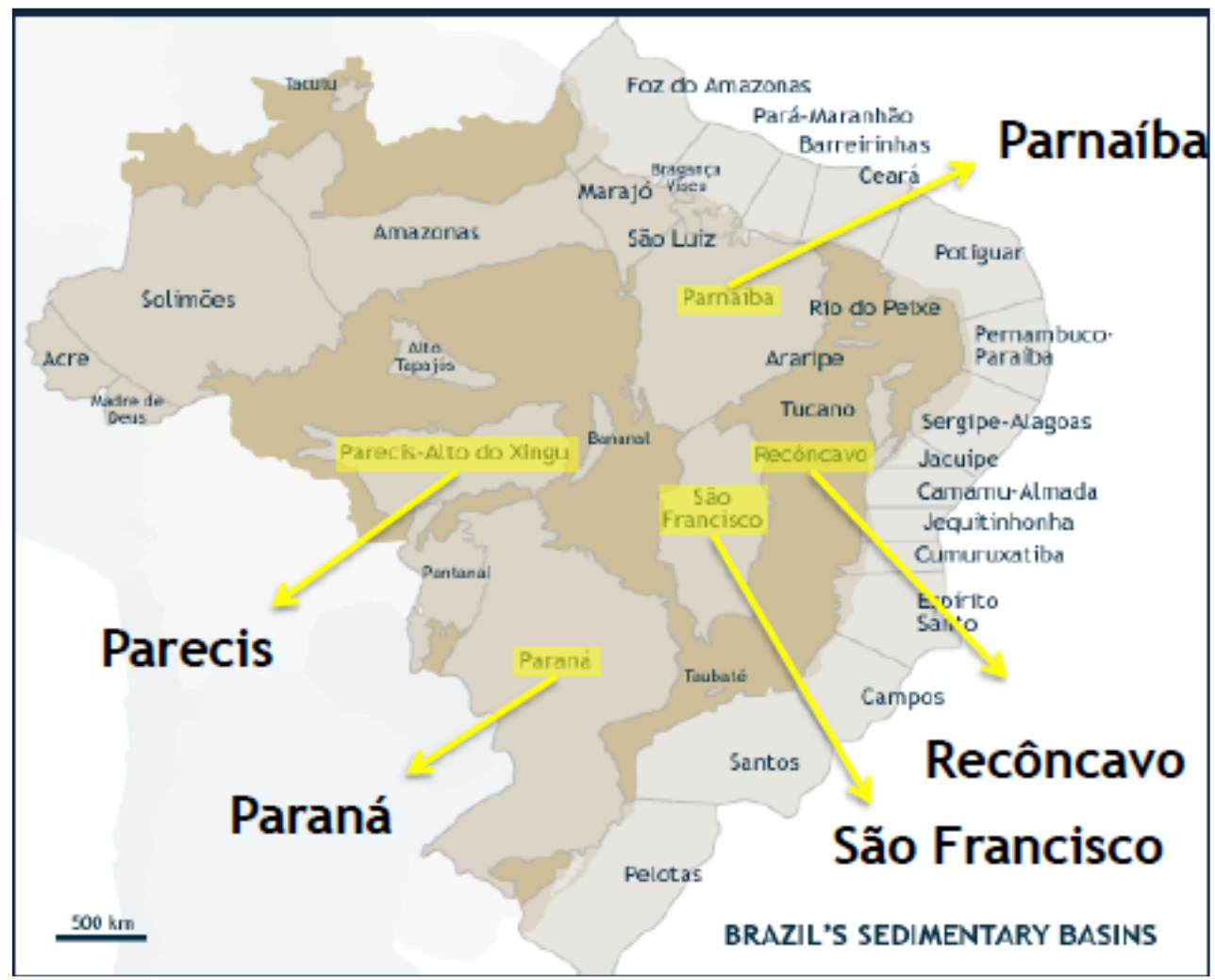

Figura 14 - Mapa do Brasil apresentando as bacias sedimentares com potencial para gás em folhelho. Fonte: ANP (2013).

\subsubsection{METANO EM ESTRATOS DE CARVÃO (COALBED METHANE - CBM)}

O chamado coalbed methane $(\mathrm{CBM})$ corresponde às acumulações de gás natural proveniente de depósitos de carvão mineral. O CBM é basicamente constituído de metano que foi adsorvido à matriz sólida do carvão ficando, portanto, aprisionado nessa litologia. A ocorrência desse tipo de gás é comum em minas subterrâneas de carvão, onde pode ser liberado naturalmente, gerando graves riscos à segurança dos operadores, especialmente devido a ameaça de explosões. O metano liberado naturalmente durante as escavações é chamado grisu (francês) ou firedamp (inglês), sendo grisu mais usual. O termo CBM é reservado para a extração desse gás a partir dos estratos de carvão mineral. Ao contrário de fontes convencionais de gás natural, o CBM se caracteriza por conter pequenas proporções de hidrocarbonetos pesados, como propano e butano, além de não apresentarem fases condensadas, também são classificados como: (i) sweet gas, devido à ausência de sulfetos de hidrogênio em sua composição, (ii) seco e não-associado ${ }^{6}$ (Halliburton, 2008).

\footnotetext{
${ }^{6}$ A classificação em sweet e sour gas é baseada na concentração de $\mathrm{H}_{2} \mathrm{~S}$ (relativamente baixa para sweet gas, com valores inferiores a 5.7 miligramas; e superiores para sour gas). O CBM também é caracterizado como gás seco não associado, devido à ausência da fase líquida (óleo) e de condensado.
} 
O gás que ocorre no carvão mineral está relacionado à matéria orgânica original, i.e., querogênio Tipo III (vitrinito), que é basicamente composta por material lenhoso (tecidos vegetais, resíduos fibrosos e fragmentos húmicos) com baixo teor de hidrogênio, mas elevado em oxigênio, havendo um maior potencial para a geração de gás do que para óleo. O gás gerado é o metano $\left(\mathrm{CH}_{4}\right)$, porém para efeitos de normatização, este gás não é chamado de natural, mas sim por seu nome tradicional grisu. Embora, com base na composição química, não existem diferença entre os gases do carvão àqueles associados ao petróleo, o termo gás natural só se aplica aos gases de petróleo. A formação do grisu, ou gás de carvão, se dá ao longo do processo de decomposição (putrefação) da matéria orgânica e consequente alteração termal que esta vai sofrendo ao longo do processo de lenta subsidência na bacia. Os primeiros membros da série do carvão têm baixa capacidade de adsorção de gás, porém quando o membro betuminoso é formado, o máximo de adsorção de gás, tanto termogênico (alteração termal) quanto biogênico (decomposição da matéria orgânica) é atingido (Figura 15). Portanto, o volume de gás na formação depende do membro da série (Halliburton, 2008).

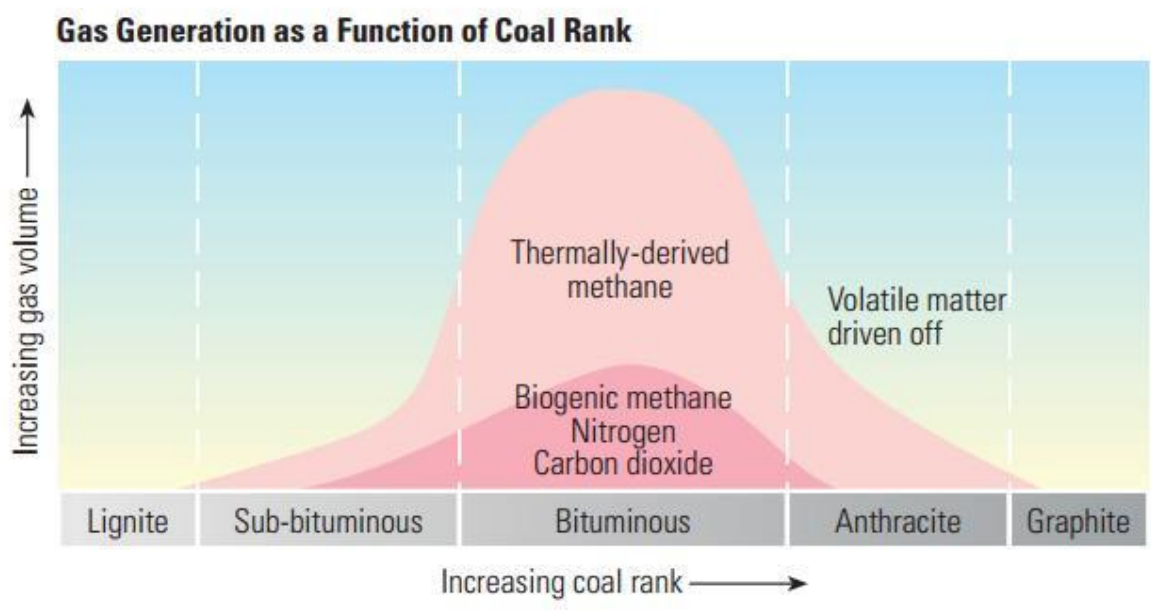

Figura 15 - Representação da geração de gás natural em relação à classificação e tipologia de carvão mineral. Halliburton (2008).

O termo metano em estratos de carvão (coal bed methane) refere-se ao gás de metano que foi gerado e aprisionado em estratos de carvão mineral. Termos como coalbed gas e coal mine methane também podem ser encontrados na literatura para denominar o CBM. Na Austrália, país com alto potencial para geração desse gás, o mesmo é titulado coal seam gas, conhecido com CSG. Apesar da existência de diversos termos, todos se referem ao mesmo tipo de deposito de gás natural associado à estratos de carvão mineral. As tentativas de viabilização da extração do gás de carvão deu origem ao termo em inglês Coalbed Methane (CBM). Com o tempo se tornou recorrente a aplicação do termo diretamente ao recurso energético (gás de 
carvão), todavia o termo CBM faz referência à extração do recurso por bombeamento (gás) e não diretamente ao recurso, o qual já era conhecido e já possuía nome próprio (gás em carvão ou grisu). Portanto, para todos os efeitos sempre deve ser feita a distinção entre recurso e forma de extração.

Este mesmo cuidado deve ser tomado ao se tratar de gás em carvão como reservatório de gás. Segundo Halliburton (2008), os mesmos são reservatórios de gás, embora não convencionais em diferentes aspectos, tais como: as propriedades de porosidade e permeabilidade, atuam parcialmente; sendo a propriedade predominante a de adsorção. Com base nessa classificação, a aplicação do conceito de sistemas petrolíferos em um contexto de CBM também deve ser adaptada, pois há elementos que compõem o sistema: rocha geradora e reservatório (estratos de carvão mineral) e migração, apesar de restrita. Neste contexto, a rocha geradora adsorve o produto se tornando o próprio reservatório. Desta forma, com base no processo de geração e acumulação, e pelas rochas geradora e reservatório estarem inseridas na mesma formação, pode-se classificar o sistema como sistema petrolífero independente (SPI), ou não convencional. Mesmo assim, o emprego do termo é questionável, pois pode ser sugerir que o carvão é gerador de petróleo.

A exploração de CBM se popularizou no mercado americano na década de 1970, fase em que os Estados Unidos vivenciavam um cenário de escassez de petróleo e declínio na produção de gás natural. A partir disso, pesquisas e investimentos foram realizados a fim de que se pudesse explorar esse recurso, bastante abundante no país em decorrência do grande uso de carvão mineral como fonte de energia elétrica. Com base nesse cenário, o departamento nacional americano de energia, fundou sedes de pesquisa em fontes não convencionais de gás natural, incluindo o CBM, cuja produção recebeu incentivos fiscais do governo, assim como o gás em folhelho e o BCG (Halliburton, 2008).

\subsection{ASPECTOS GEOLÓGICOS}

Os sistemas petrolíferos de CBM diferem dos demais sistemas não convencionais de gás natural por ter no processo de adsorção o principal mecanismo de acumulação de gás: ao invés de acumular nos espaços vazios entre os grãos (porosidade), o CBM acumula na superfície sólida do carvão mineral, em microporos, devido as propriedades de sua matriz ${ }^{7}$.

\footnotetext{
${ }^{7}$ A matriz presente em rochas sedimentares como o carvão mineral, se apresentam ricas em matéria orgânica. Esta possui a capacidade de reabsorver moléculas de gás natural que foram geradas no sistema. Sendo assim, moléculas
} 
Além dessa propriedade, rochas sedimentares como o carvão mineral apresentam baixa permeabilidade, retendo o fluido na própria litologia. Esta assume o papel de rocha geradora, reservatório e selante, assim como o caso de sistemas petrolíferos de gás em folhelho. A geração de gás natural em carvão ocorre devido ao continuo processo de soterramento e compactação do pacote, resultando em condições mais elevadas de pressão e temperatura, e consequente geração de gás (Halliburton, 2008).

O CBM tem sua geração associada ao processo de termogênese e biogênese. O metano produzido em estágios mais primários de formação de gás natural, como linhitos, é decorrente do processo de biogênese (decomposição bioquímica), o qual consiste na quebra de moléculas de hidrocarbonetos devido ação bacteriana. Além da atuação desse processo, também ocorre a geração de gás termogênico, associado a estágios mais avançados de maturação termal (Figura 16).

de gás natural se apresentam associadas à matriz do carvão mineral, acumulando-se nas superfícies do sistema e caracterizando a propriedade de adsorção, de forma semelhante situação anteriormente descrita para gás de folhelho. 

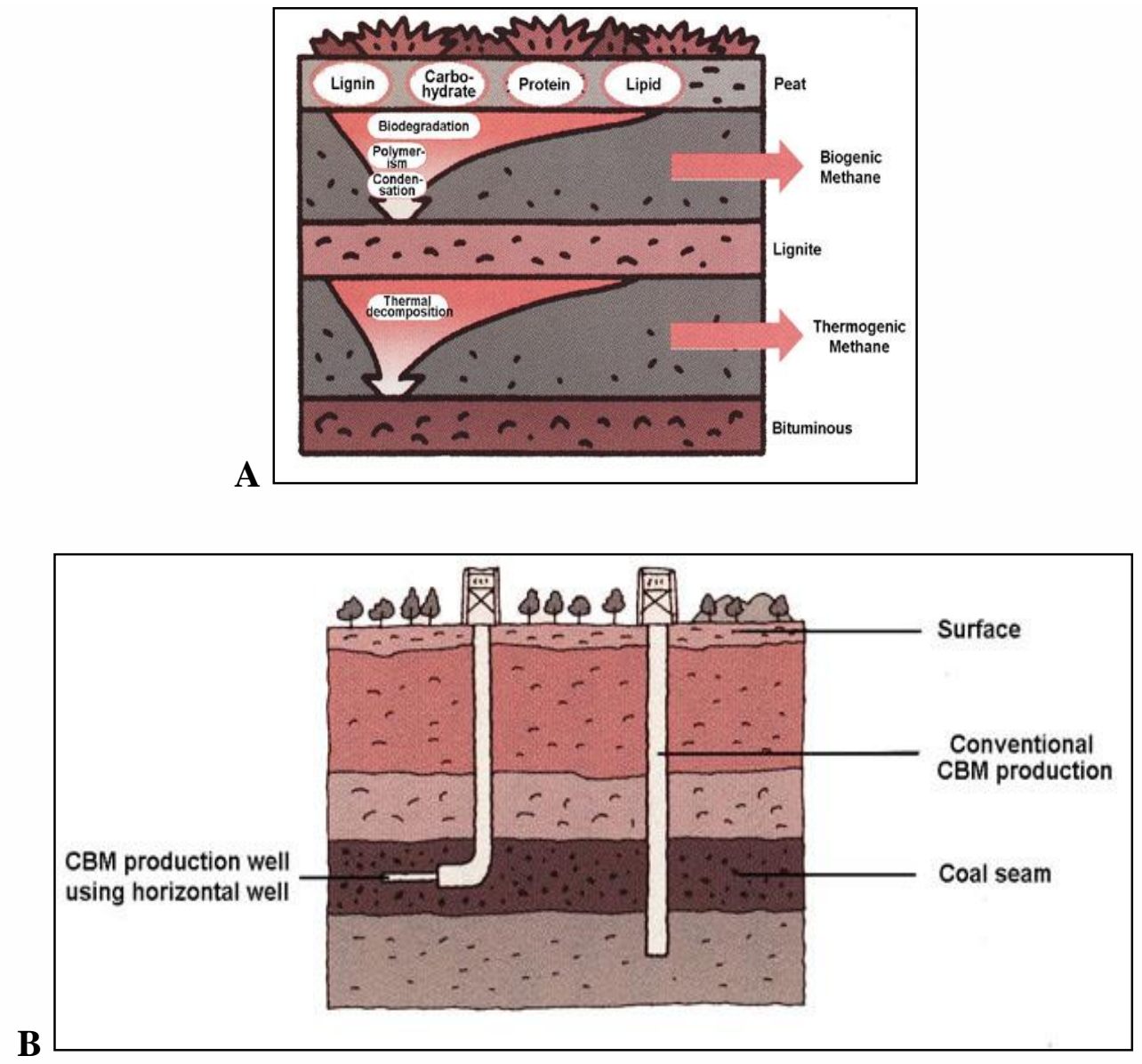

Figura 16 - Ilustração referente à disposição de camadas de carvão mineral saturadas em CBM. A: Representação de estágios de formação de carvão mineral com os respectivos processos envolvidos na geração de gás biogênico e termogênico (CBM). B: Representação dos possíveis modelos exploratórios de CBM, a partir de perfuração vertical e de perfuração horizontal.

Fonte: Sekitan no hon (2009).

\subsection{CENÁRIO ATUAL}

O metano se destaca dentre outros combustíveis fósseis por relativa baixa emissão de poluentes e de seu baixo custo de produção. Em um cenário de grande procura por recursos energéticos mais limpos e baratos, o metano se apresenta como forte competidor no mercado de combustíveis fósseis. Além disso, depósitos de metano se apresentam em volumes abundantes e em distribuição ampla mundial, principalmente nos Estados Unidos, onde sua exploração foi pioneira, sendo encontrado em quantidades superiores a 800 Tcf em depósitos de carvão. Nesse contexto, o metano deixou sua imagem de vilão das minas de carvão e passou a ser considerado como uma fonte energética amigável ao meio ambiente (Halliburton, 2008).

De acordo com Halliburton (2008), a exploração de CBM traz inúmeros benefícios para a indústria petrolífera ao: fornecer um combustível limpo elevado potencial energético (poder calorífico); ampliar a reserva mundial de gás natural; aumentar a segurança em minas de carvão, 
onde vazamentos de CBM podem causar acidentes; reduzir a taxa de poluentes emitidos na atmosfera a partir da combustão de recursos fósseis, e disponibilizar carvão mineral para a exploração. No entanto, o autor desconsidera os impactos ambientais relacionados à exploração de carvão mineral e a contribuição do metano para o efeito estufa.

\subsection{OCORRÊNCIA}

A exploração de gás natural a partir de estratos de carvão mineral tem se tornado uma importante ferramenta na busca por recursos energéticos a fim de atender a sociedade moderna. Condições de mercado financeiro e avanços tecnológicos tornaram possível a viabilidade a explotação desse recurso. Atualmente, a produção de CBM representa uma parcela importante na economia norte americana: $10 \%$ da produção anual de gás natural do país são provenientes de estratos de carvão (1.5 Tcf ou 4.9 bilhões de $\mathrm{m}^{3}$ ), e aproximadamente $9.5 \%$ do total de reservas de gás natural do país corresponde a esse tipo de acumulação (Anderson et.al. 2003).

Segundo EIA (2012), a partir da busca por menores impactos ambientais e menos custo, a produção de CBM recebeu grandes investimentos da indústria americana. As regiões de Montanhas Rochosas, no Colorado, e das Montanhas Apalache, no leste dos Estados Unidos, são as principais áreas com produção de CBM, no entanto, esse recurso pode ser explorado em qualquer região com reservas de carvão mineral, como nos estados de Montana, Wyoming, dentre outros estados americanos (Figura 17). 


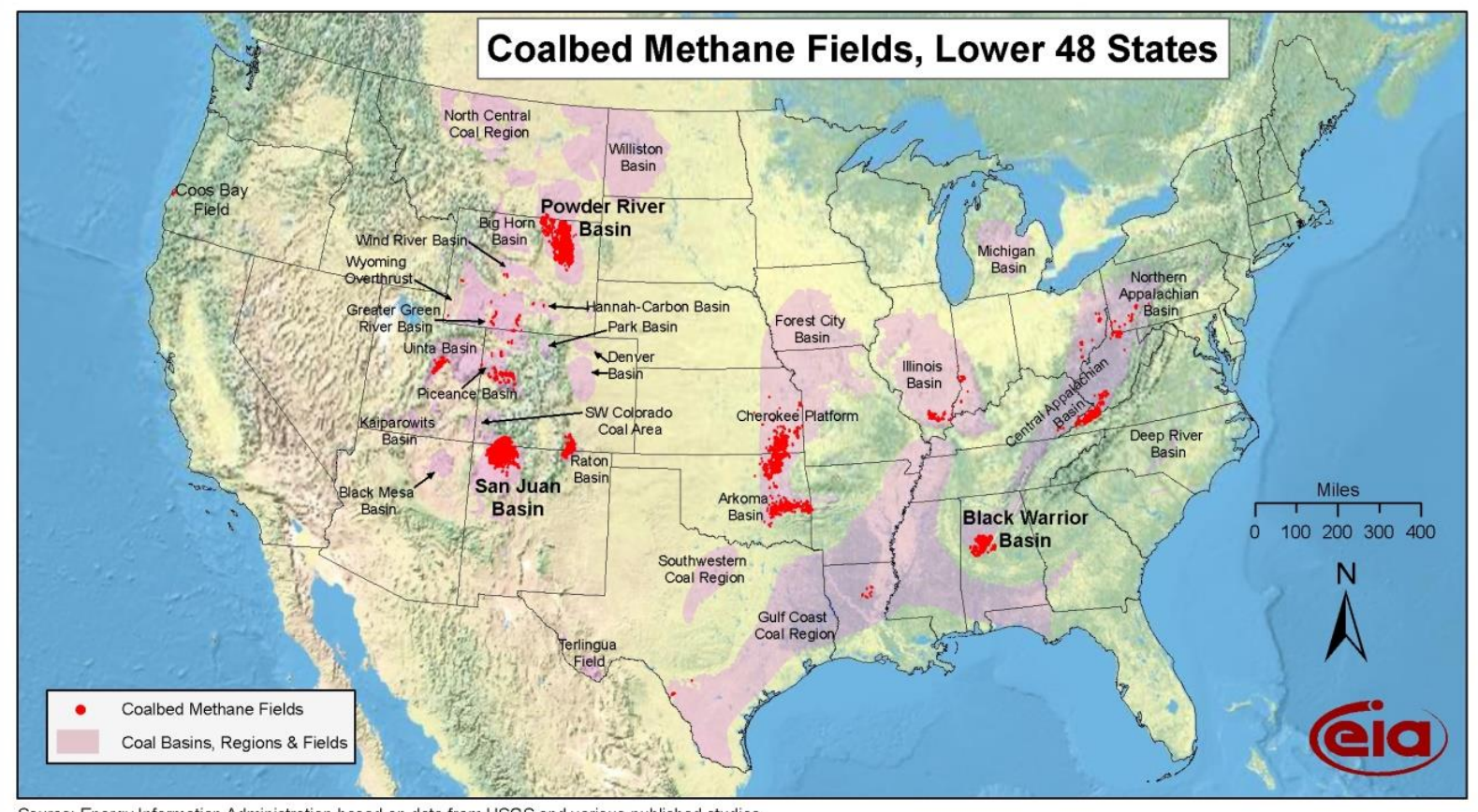

Source: Energy Information Administration based on data from USGS and various published studies Updated: April 8, 2009

Figura 17 - Mapa dos Estados Unidos apresentando a distribuição e dimensão das principais bacias sedimentares geradoras de coal bed methane (CBM).

Fonte: EIA (2015).

Além dos Estados Unidos, o CBM é também significativamente produzido na região de Queensland, na Austrália, e no Reino Unido. Projetos piloto também vêm sido implantados em países como China e Índia, além de diversos outros países que apresentam grandes depósitos de carvão mineral, onde o CBM é produzido. Os países com maior potencial são: Estados Unidos, Espanha, França, Polônia, Austrália, Canadá, China, Grã-Bretanha, Alemanha, Zimbabwe, e Rússia (EIA, 2012).

\subsubsection{GÁS EM RESERVATÓRIOS DE BAIXA PERMEABILIDADE (BASIN CENTERED GAS - BCG \& TIGHT GAS)}

O conceito de BCG teve início com Master em 1979, através de publicações sobre reservatórios areníticos de baixa permeabilidade na região de Alberta, no Canadá (definição atualmente atribuída ao tight gas). Em sua análise de arenitos saturados em gás natural, os quais eram denominados de gás em bacias profundas, Master (apud McCullagh \& Hart, 2010) sugeriu que a baixa permeabilidade poderia agir como uma barreira que impedisse a continuação da migração do fluido, teoria base para acumulações de BCG. Essas acumulações se diferem do trapeamento convencional, sendo tipicamente caracterizadas por sistemas saturados em gás, com pressões anômalas e baixa permeabilidade. Acumulações de BCG variam de sistemas petrolíferos individuais (independentes), sendo isolados e de baixa espessura, até sistemas 
múltiplos e de maior profundidade, diferenças as quais implicam nas estratégias de exploração (McCullagh \& Hart, 2010).

Devido controvérsias de conceitos e escassez de estudos, o BCG recebeu diversas denominações ao longo dos anos. O termo tight gas é geralmente utilizado na literatura como definição de sinônima de BCG. Em muitos casos, o termo BCG não é incorreto, entretanto, pode gerar significado ambíguo, podendo se referir a acumulações com trapeamento convencional de gás natural (acumulações geradas a partir da diferença entre densidade e empuxo na coluna de óleo ou gás) ao invés de reservatórios com permeabilidade reduzida. Além disso, o termo tight gas tende a se referir a reservatórios areníticos compactados enquanto que BCG pode se referir a sistemas petrolíferos não convencionais situados na porção central de bacias sedimentares (em virtude dessa maior compactação), ou seja, BCG se refere ao posicionamento do sistema e não especifica sua litologia. O termo deep basin gas (acumulações de bacia profunda), também pode ser bastante encontrado na literatura, apesar de seu uso ser inadequado: acumulações de BCG geralmente não se apresentam em grandes profundidades; assume-se que o termo se refere, unicamente, a acumulações em profundidades superiores a $15.000 \mathrm{ft}(4.572 \mathrm{~m})$ (Law, 2002). Outro termo encontrado é continuous gas accumulation (acumulações contínuas de gás natural), no entanto, é um termo de aplicação muito generalizada, podendo referir-se também a gás de folhelho (shale gas). Devido à ausência de consenso a respeito da denominação, o termo mais adequado, e optado pelo presente trabalho como definição oficial é de gás em reservatórios de baixa permeabilidade, termo que engloba ambas as definições de tight gas e BCG.

\subsection{ASPECTOS GEOLÓGICOS}

Sistemas de BCG correspondem a acumulações regionais saturadas em gás natural, com pressões anômalas (tanto baixas como altas), comumente com ausência do contato água e gás, e apresentam reservatórios caracterizados por baixa permeabilidade. Em relação ao sistema petrolífero, existem dois tipos de sistemas de BCG: um tipo direto e um tipo indireto, que podem ser diferenciados com base nas propriedades de suas rochas geradoras. O sistema direto apresenta rochas com potencial gerador para gás (gas-prone source rock, a partir de querogênio tipo III), enquanto que o sistema indireto, potencial gerador de óleo (oil-prone source rock, a partir de querogênio tipo I e II), diferença a qual vem a influenciar em diversas outras propriedades como a maturidade termal e o mecanismo de pressão. Além desses dois tipos de 
sistemas, existem sistemas híbridos, nos quais ambos os tipos de rochas geradoras (com potencial para óleo e para gás), contribuíram na formação do sistema (Law, 2000).

De acordo com Law (2002), o desenvolvimento de um sistema de BCG pode ser analisado através de quatro ciclos de pressão de reservatório (Figura 18). Esses ciclos são determinados a partir da dinâmica dos processos geológicos envolvidos e pela resposta do sistema a esses processos. Os ciclos representam fases evolutivas do sistema em relação à pressão envolvida, e serão detalhadamente descritos a seguir.

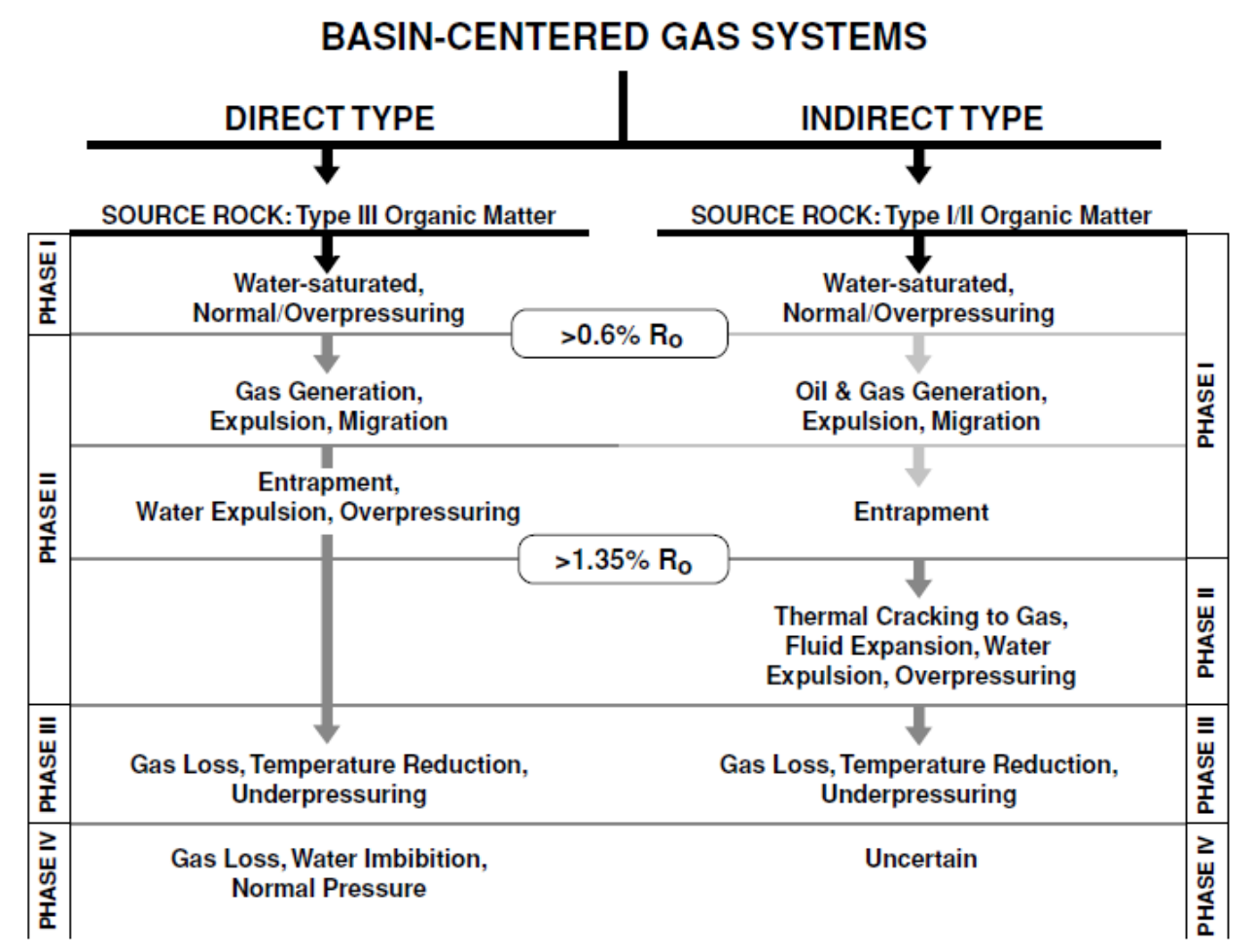

Figura 18 - Digrama esquemático representando a evolução de sistemas diretos e indiretos de acumulações de Basin Centered Gas (BCG) ou tight gas.

Fonte: Law (2002).

\section{- Fase I}

Durante o início do processo de soterramento e de atividade termal de sistemas diretos e indiretos, os reservatórios, geralmente, apresentam pressão normal, e a porosidade da rocha se apresenta $100 \%$ saturada em água. A compactação e o arranjo dos grãos são importantes elementos nesse processo. A definição da fase I se difere de sistemas diretos para indiretos: em sistemas diretos, a fase I termina com a geração de gás termal, enquanto que em sistemas indiretos, termina com o início do craqueamento termal de óleo para gás. Além disso, durante a fase I, sistemas indiretos tendem a apresentar reservatórios de melhor qualidade quando comparados à sistemas diretos devido as acumulações por diápiros de óleo exigirem maior porosidade e permeabilidade do que o gás natural. Em casos excepcionais, reservatórios podem 
apresentar pressão anômala durante a fase I: situação gerada a partir de eventos deposicionais de rápida sedimentação, resultando em compactação heterogênea e consequente elevação de pressão no sistema. Nessas situações, a água do sistema equivale à fase fluida que exerce essa pressão. No entanto, em decorrência da progressão da continuidade do processo de compactação e soterramento associado ao aquecimento do sistema, a geração de hidrocarbonetos pode vir a substituir a fase fluida e ser responsável pelo aumento de pressão no sistema. Como exemplos dessa transição de mecanismos de pressão, temos as formações datadas do Mioceno e Plioceno nas bacias Bekes e Makó, situadas na Hungria (Law \& Spencer, 1998).

\section{- Fase II}

Sistemas diretos são constituídos por rochas com potencial gerador para gás em proximidade com reservatórios de baixa permeabilidade. À medida que o sistema se expõe a condições de mais elevada taxa de compactação e temperatura, a geração de gás natural se inicia, concomitante à expulsão e migração desse gás para arenitos saturados em água e de disposição adjacente. Devido essas rochas reservatório apresentarem baixa permeabilidade, a taxa de geração e acúmulo do gás nos poros é maior que a taxa de perda desse fluido. Dessa maneira, a pressão de capilariedade dos poros é excedida, liberando a água antes presente no sistema e resultando em reservatórios de elevada pressão, saturados em gás, e com pouca ou nenhuma água no sistema. Como exemplos desse sistema têm-se as bacias: Greater Green River, Wind River, Big Horn, e Piceance, situadas na região das Montanhas Rochosas, nos Estados Unidos; e a bacia Taranaki, na Nova Zelândia. Em contraste aos sistemas diretos, sistemas indiretos se constituem em rochas com potencial gerador para óleo, o qual é gerado, expelido e acumulado em reservatórios a partir de trapas estruturais e/ou estratigráficas em forma de diápiros, sobrepostos à água presente no sistema. Com o subsequente soterramento e exposição a maiores temperaturas, as acumulações de óleo sofrem o craqueamento termal e consequente geração de gás, processo associado a significativo aumento de pressão e volume de fluidos no sistema. Sob essas condições de elevado volume e pressão, ocorre também um aumento na pressão de capilariedade dos poros saturados, expelindo moléculas livres de água e substituindo a saturação por gás natural. Além da ocorrência desse processo, o sistema necessita da presença de uma litologia selante para que a acumulação inicial de óleo seja possível. 
- Fase III

À medida que os sistemas de BCG se tornam expostos a condições de sobrepressão, o processo relacionado à transição da fase II (fase de sobrepressão) para a fase III é idêntico para ambos os sistemas direto e indireto. Segundo Law (2002), a fase III ocorre quando uma fase em sobrepressão se expõe a condições de pressão reduzida, decorrentes de atividade tectônica e/ou erosionais, além de possíveis perturbações de fluxo de calor. Eventos de soerguimento descrevem essa situação, representando interrupções na história termal e na continuidade do soterramento e compactação do sistema. Esses eventos representam redução de temperatura e pressão, além de resultarem em perdas de gás do sistema. Estudos apontam que ocorre maior perda de gás em sistemas diretos do que em sistemas indiretos, fato decorrente da integridade das rochas selantes. Exemplos de sistemas diretos com pressão reduzida de fase III são observados nas rochas cretáceas nas bacias de San Juan, Raton, e Denver, nos Estados Unidos; e como exemplos de fase III em sistemas indiretos temos as rochas do Siluriano na bacia Apalache (EUA), rochas Ordovicianas em Risha (Jordânia), e reservatórios CambroOrdovicianos da bacia Ahnet (Argélia).

- Fase IV

De acordo com Law (2002), a fase IV é de caráter teórico, tendo seu conceito mais aplicável á sistemas diretos, visto que rochas selantes apresentam melhor eficácia em sistemas indiretos do que em sistemas diretos. A fase IV corresponde a uma contínua perda de gás do sistema devido à pressão de capilariedade, associada à lenta e gradual reentrância de água no sistema saturado em gás em virtude da pressão reduzida. Dessa maneira, Law (op.cit.) sugere a hipótese de que esses sistemas, saturados em gás e de baixa pressão, evoluem para sistemas de pressão normal, completando um ciclo entre as fases de pressurização. Elementos de sistemas petrolíferos de BCG apresentam características específicas, que ajudam a diferenciar sistemas diretos e indiretos. A natureza da rocha geradora é o principal fator que distingue os dois sistemas. Rochas geradoras de sistemas diretos são, geralmente, representadas por camadas de carvão tipo húmico e por folhelhos carbonáticos, enquanto sistemas indiretos apresentam folhelhos ricos em hidrogênio. As rochas carbonáticas desses sistemas foram descritas por Law (2002) como regionais pervasivos que geralmente constituem reservatórios isolados de baixa espessura ou de disposição vertical atingindo elevadas profundidades. Para ambos os sistemas, as rochas reservatório apresentam baixa porosidade (inferior a 13\%) e baixa permeabilidade $(<0.1 \mathrm{mD})$. São compostos de arenitos, siltitos e, raramente, carbonatos. O ambiente de 
deposição desses sistemas varia de marinho a não marinho. Com base em sua morfologia, os reservatórios de BCG podem ser divididos em lenticulares, como arenitos de canal deltaico, apresentando baixo volume de poros e permeabilidade muito baixa; e em forma de lençóis, como de rios entrelaçados, frente deltaica e arenitos eólicos, apresentando maior volume de poros e permeabilidade quando comparado a reservatórios lenticulares. A distinção entre esses tipos de reservatório é importante fator para a fase de perfuração. As rochas selantes dos sistemas de BCG são relevantes para a separação de reservatórios, entre camadas saturadas em água e camadas saturadas em gás (figura 19). A natureza dos limites entre esses fluidos é determinada a partir da integridade do selante, o qual pode variar de litológico (rochas de baixa permeabilidade) a mecânico (a partir de pressão de capilariedade) (Law, 2002).

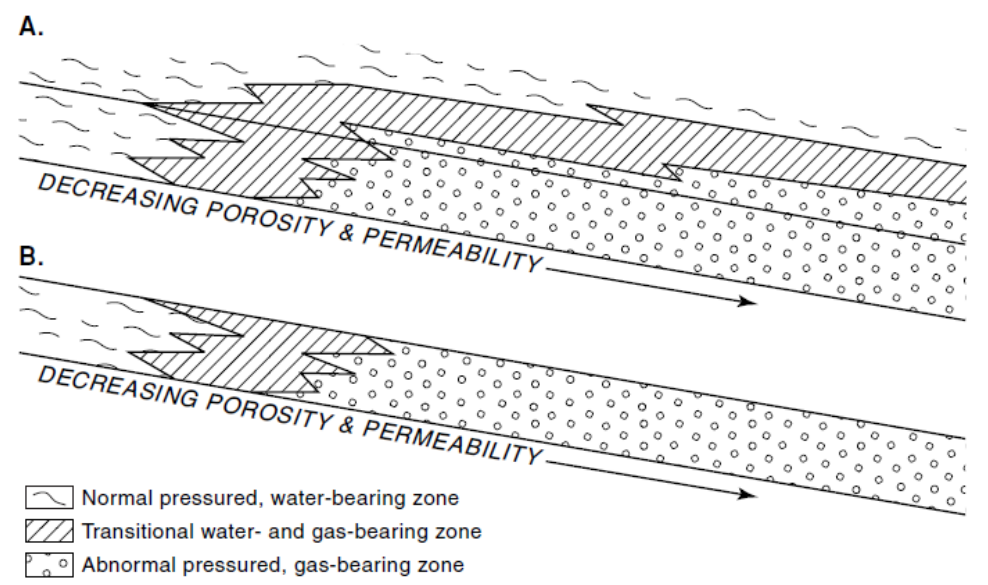

Figura 19 - Ilustração representando limites transicionais entes camadas rochosas de pressão normal, saturadas em água, e camadas em sobrepressão, com saturação em gás natural, e sua distinção em sistemas diretos (A) e indiretos (B) de BCG.

Fonte: Law (2002).

Em relação aos processos atuantes em sistemas petrolíferos tipo BCG, a geração de hidrocarbonetos e a mudança de estado físico do óleo para o gás, devido à sobrepressão característica desses sistemas, ocorrem em condições mais elevadas de maturação termal. De modo geral, a migração de hidrocarbonetos em sistemas tipo BCG é executada em curtas distâncias (contato imediato entre rocha geradora e reservatório), apesar de que podem ocorrer exceções em casos de deformação rúptil do sistema, onde o gás pode percorrer maiores distâncias a partir de falhas e fraturas. A formação de trapas é bastante importante em sistemas indiretos, sendo considerada secundária em sistemas diretos. Em sistemas diretos, o topo do sistema supera limites estruturais e estratigráficos, não sendo necessário o desenvolvimento de trapas dessa natureza. Já no caso de sistemas indiretos, o trapeamento convencional é essencial para que ocorra a acumulação de hidrocarbonetos, assim como em sistemas convencionais (Law, 2002). 
De acordo com dados da empresa Schlumberger (2013), a identificação de sistemas tipo BCG pode ser realizada a partir de análises de ambientes deposicionais e diagênese relacionada, além da identificação de reservatórios independentes e da ausência de contato entre gás natural e água confinada, em associação com estudos da história termal e compactação do sistema a fim de que ocorram as condições necessárias para a formação desse tipo de sistema petrolífero. Segundo a ExxonMobil (2013), os Estados Unidos vêm produzindo BCG por mais de quatro décadas e, em virtude de seu investimento em pesquisa e tecnologia, muitos depósitos já foram identificados e atualmente esse recurso já representa cerca de $40 \%$ da produção nacional de gás natural não convencional.

\subsection{CENÁRIO ATUAL}

Sistemas de BCG são considerados um dos sistemas não convencionais de maior importância econômica no cenário mundial; contribuindo com mais de $40 \%$ da produção total anual de gás natural nos Estados Unidos (ExxonMobil, 2013). A atividade exploratória de BCG tem sido concentrada na América do Norte, especialmente nos Estados Unidos. Em outras partes do mundo, os conceitos de BCG ainda são pouco conhecidos e a exploração desse recurso ainda é pouco realizada devido à escassez de informações, apesar do contínuo progresso. Para se desenvolver e incentivar essa exploração são necessários estudos e quebras de paradigmas a respeito de sistemas petrolíferos, modificando conceitos tradicionais e introduzindo novos conceitos sobre sistemas não convencionais

\subsection{OCORRÊNCIA}

A ocorrência de reservatórios de baixa permeabilidade é bastante presente nos Estados Unidos, principalmente na região das Montanhas Rochosas e das Montanhas Apalache, além de diversas outras bacias sedimentares que possuem as condições necessárias para a geração de BCG (EIA, 2012), conforme o representado na Figura 20. 


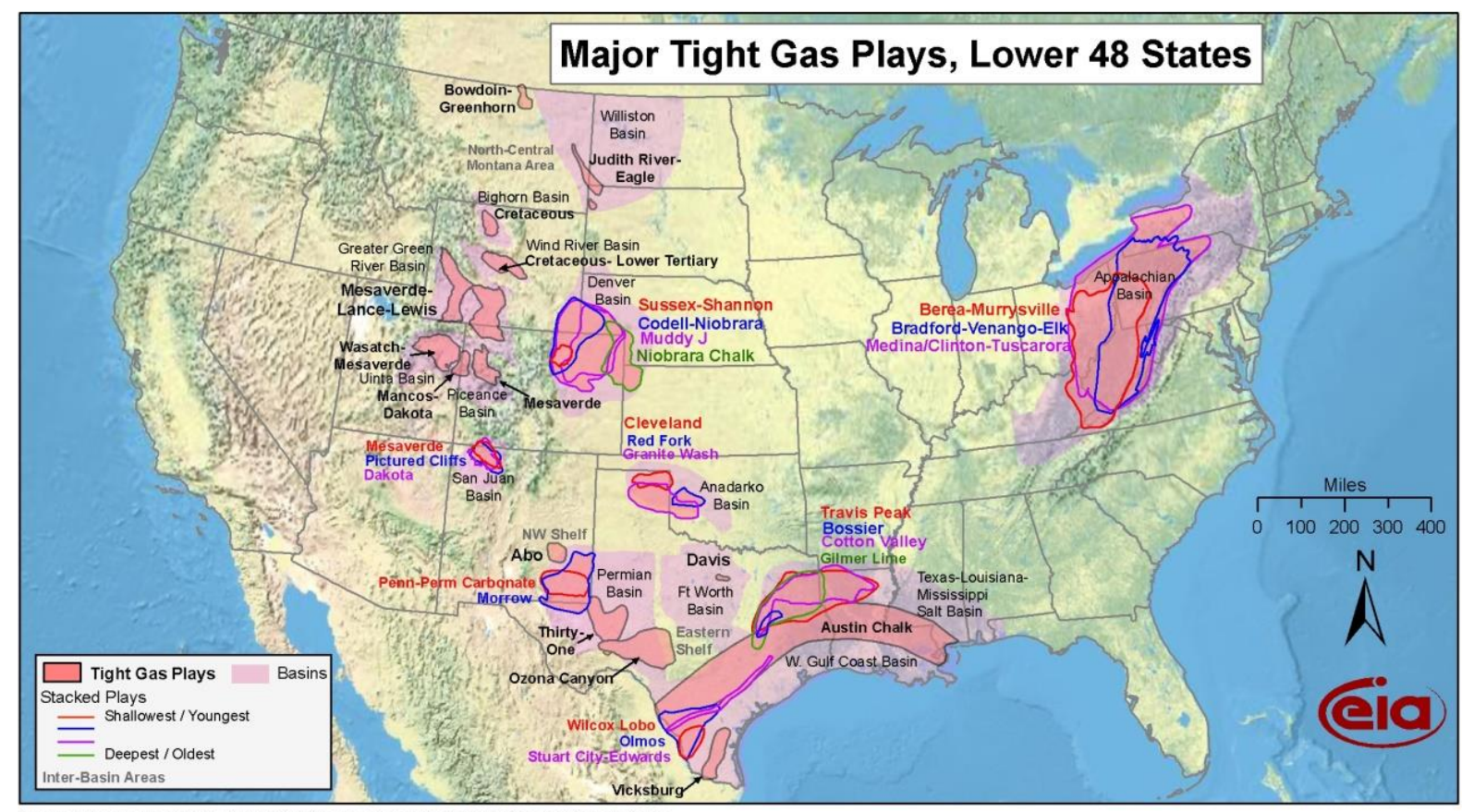

Source: Energy Information Administration based on data from various published studies
Updated: June 6, 2010

Figura 20 - Mapa dos Estados Unidos apresentando a distribuição geográfica de depósitos conhecidos de BCG.

Fonte:

EIA (2015)

\subsubsection{TÉCNICAS DE EXPLORAÇÃO}

O principal objetivo de atividades de exploração é a definição de áreas de perfuração. No caso de recursos energéticos não convencionais, as estratégias de exploração geralmente se dão em quatro etapas: reconhecimento, confirmação, delimitação, e identificação de sweet spots (Law, 2002). Essas estratégias são aplicadas para a produção de óleo e gás natural, e devem considerar elementos como a rocha geradora, reservatório, níveis de maturação termal e a relação temporal entre os esses elementos e os processos de geração, expulsão, migração e acumulação, relacionados ao sistema petrolífero em questão.

A fase de Reconhecimento corresponde à identificação de bacias sedimentares com potencial gerador de gás natural não convencional. Para isso, deve-se avaliar a natureza da rocha geradora e as propriedades dos reservatórios (porosidade e permeabilidade). ${ }^{8}$ Uma vez identificada uma bacia com potencial petrolífero, se inicia a fase de Confirmação. Como grande parte dos reservatórios de gás não convencionais apresenta pressões anômalas, a fase de confirmação desses sistemas avalia os valores de pressão do reservatório e os mecanismos responsáveis pela pressão anômala, geralmente medidos por métodos indiretos como análises

\footnotetext{
${ }^{8}$ No caso da exploração de BCG, por exemplo, a identificação de camadas de carvão mineral saturadas em gás termogênico, associadas a rochas areníticas com baixa permeabilidade e porosidade, é importante para a fase de Reconhecimento, atuando como forte evidência de potencial concentração de BCG.
} 
da velocidade das ondas sonoras emitidas no sistema. A fase de Delimitação do sistema consiste no mapeamento vertical e na distribuição espacial de acumulações de hidrocarbonetos. A delimitação das acumulações geralmente é baseada em dados adquiridos durante a fase de Confirmação, analisando padrões de pressão anômala. Por último, é efetuada a fase de identificação de sweet spots (áreas de maior concentração de gás no sistema), visto que o gás natural geralmente não se distribui igualmente ao longo do reservatório. A identificação dessas porções de maior concentração é baseada em aspectos estruturais e estratigráficos do reservatório, além de levar em consideração as áreas de pressão anômala. Uma vez definidas as áreas de exploração, são aplicadas técnicas exploratórias que permitam a recuperação desse recurso (Law, 2002).

A baixa permeabilidade característica de sistemas petrolíferos não convencionais como o gás em folhelho, metano em estratos de carvão, gás em reservatório de baixa permeabilidade corresponde ao principal fator limitante à exploração de gás natural a partir desses sistemas. No entanto, o desenvolvimento de técnicas de exploração como a perfuração horizontal e o fraturamento hidráulico, permitiu a comercialização desse gás natural não convencional.

\subsubsection{PERFURAÇÃO HORIZONTAL}

A técnica de perfuração horizontal, também conhecida como perfuração direcional, corresponde ao processo de perfuração de poços em que se executa o desvio da rota inicialmente vertical, intersectando o reservatório em uma inclinação praticamente horizontal. Como a maioria dos reservatórios é mais extensa lateralmente do que em espessura, a técnica permite um melhor acesso ao fluido concentrado nesse reservatório, intensificando sua recuperação. Dessa maneira, a perfuração horizontal resulta na maior exposição da rocha saturada em hidrocarbonetos do que a técnica convencional de perfuração vertical, por penetrar o reservatório de maneira perpendicular ao plano de maior dimensão. $\mathrm{O}$ ponto em que ocorre o desvio da rota de perfuração vertical é denominado kickoff point, marcando o momento em que a perfuração passa a intersectar com angularidade. $\mathrm{O}$ momento em que a perfuração atinge a rocha saturada é denominado entry point (ponto de entrada), a partir da qual será efetuada e explotação/produção de hidrocarbonetos (Figura 21) (Zou et.al. 2013). 


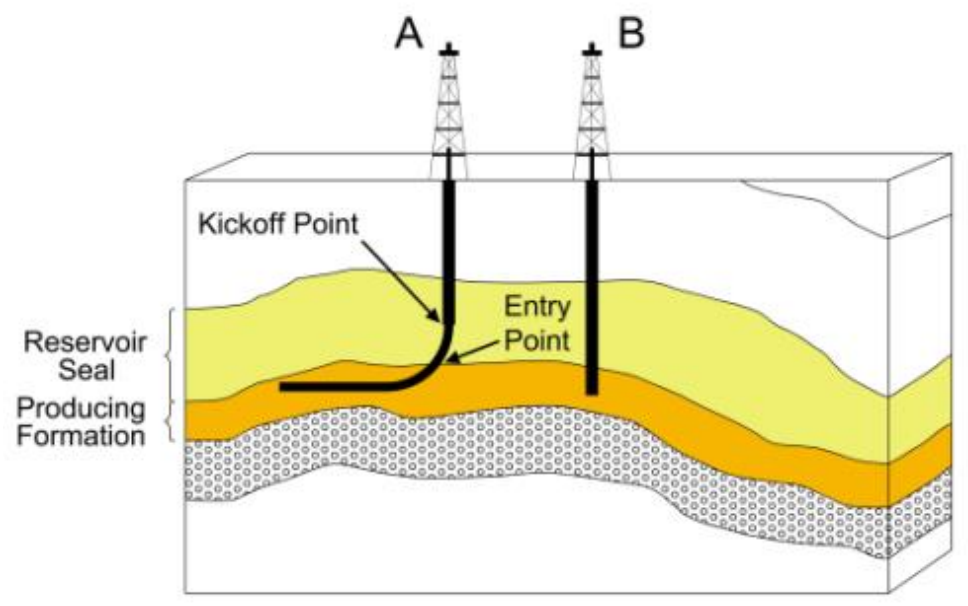

Figura 21 - Representação esquemática de técnicas de perfuração vertical e horizontal. A: Formação saturada em hidrocarbonetos sendo exposta à perfuração horizontal, indicando os pontos de kickoff e entry. B: Recuperação por meio de perfuração convencional (vertical). Fonte: EIA (2013).

A metodologia da técnica de perfuração horizontal engloba um sistema rotatório constituído de brocas e tubos de perfuração, padrão para ambas as técnicas vertical e horizontal. Desde o ponto de kickoff ao ponto de entry, a seção curva é perfurada por meio de motores de funcionamento hidráulico, estes atuam rotacionando o tubo de perfuração e gerando uma inclinação a partir do motor de superfície. Pacotes instrumentais acoplados ao tubo de perfuração são os responsáveis por transmitir dados em sensores para os operadores em superfície. Geralmente, esses sensores fornecem ângulos em azimute para que a inclinação do sistema seja determinada. Sistemas mais modernos permitem que os operadores em superfícies possam identificar a posição da broca (a partir e coordenadas $\mathrm{x}, \mathrm{y}$ e z) durante todo o momento de perfuração. Os sensores também providenciam informações sobre o ambiente de perfuração, apresentando valores de pressão e temperatura, velocidade de rotação e peso exercido pelo pacote rochoso sobre o tudo de perfuração, com a finalidade de se evitar ou reduzir o desgaste do equipamento (Schlumberger, 2012).

Diversas vantagens são apresentadas a partir de técnicas de perfuração horizontal. Além de aumentar a superfície de contato entre o reservatório e o poço exploratório, a técnica permite a exploração em regiões não antes alcançáveis, como reservatórios situados sob centros urbanos, massas de água, entre outros. A técnica também favorece a exploração em rede, facilitando que outros poços possam ser acoplados ao sistema de perfuração, e que o fluido possa ser explotado em diferentes direções, processo determinado perfuração multilateral (Figura 22). No entanto, segundo Schlumberger (2012), a implantação dessa sofisticada técnica exploratória apresenta um custo: um poço horizontal pode custar $300 \%$ mais do que o custo de poços convencionais. Diante dessa situação, a técnica de perfuração horizontal é geralmente 
restrita a situações me que a perfuração vertical não é efetiva para a recuperação de hidrocarbonetos ${ }^{9}$, apesar de ser bastante presente nos Estados Unidos (Figura 23).

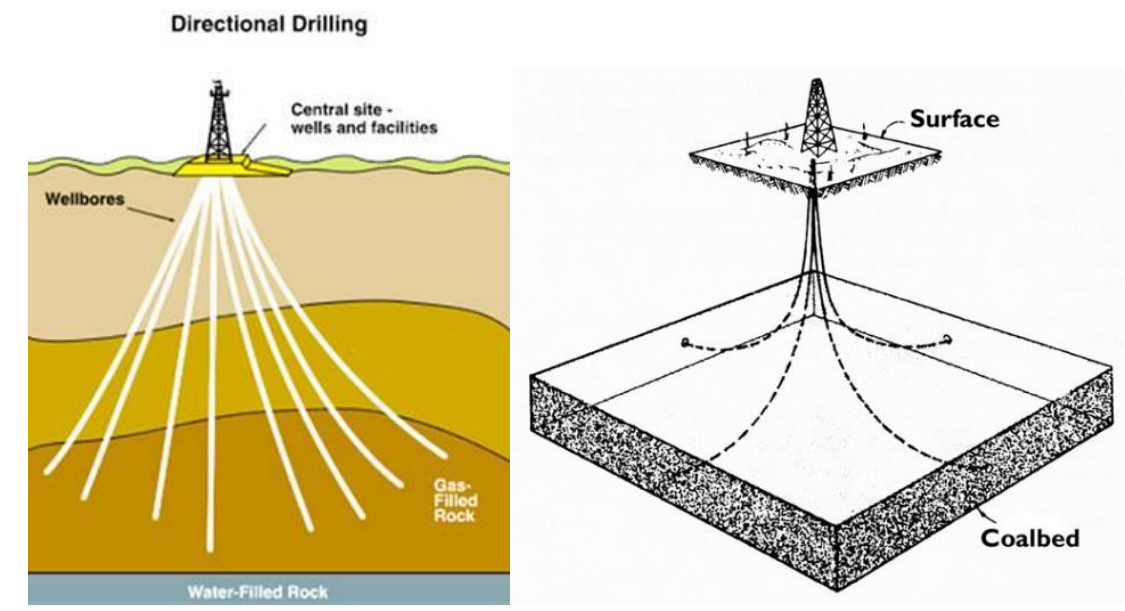

Figura 22 - Representação esquemática da técnica de perfuração em rede, também denominada perfuração multi-lateral, onde diversos tubos de perfuração são acoplados à central de perfuração com a finalidade de possibilitar e explotação do fluido em diversas direções durante o mesmo intervalo de tempo. Fonte: EIA (2013).

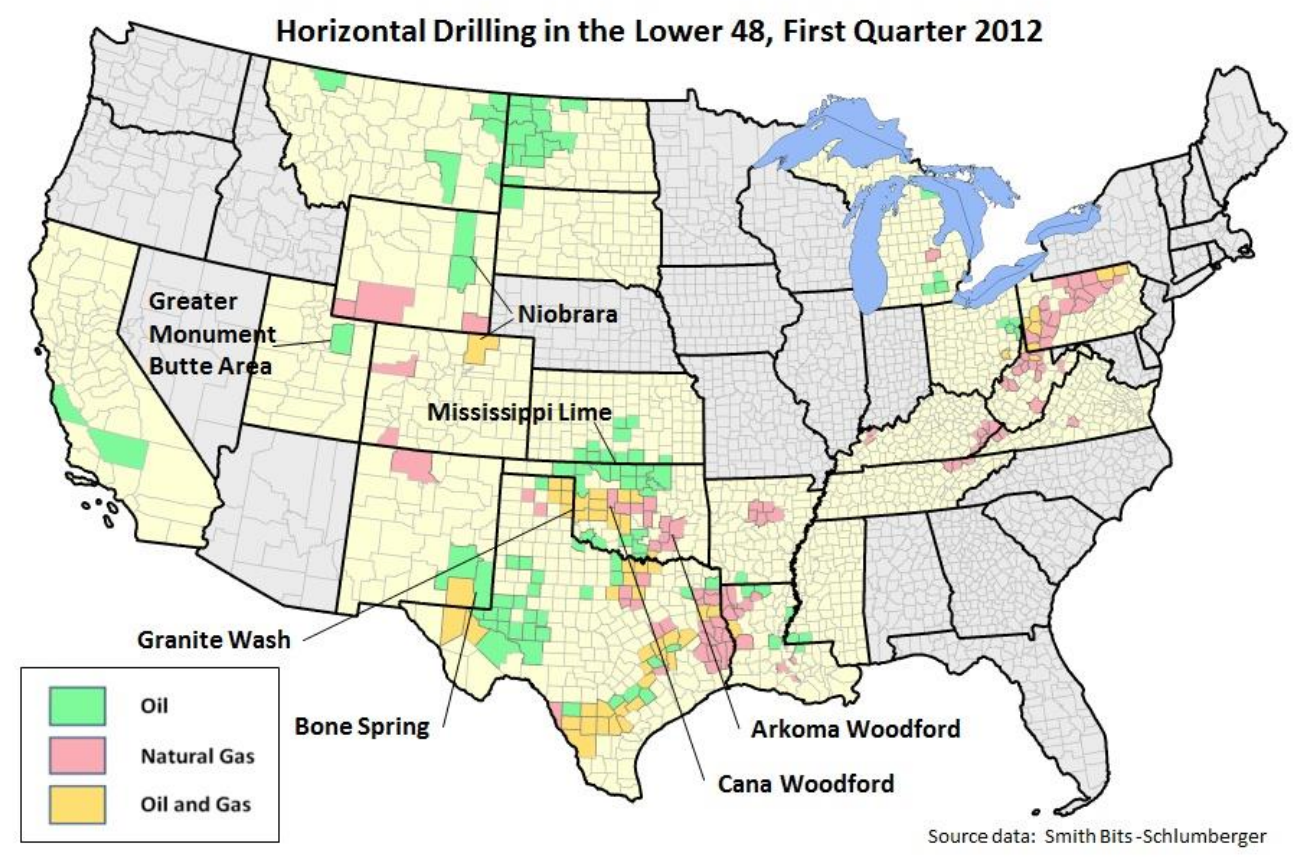

Figura 23 - Mapa dos Estados Unidos representando áreas em que a técnica de perfuração horizontal vem sido implantada.

Fonte: Schlumberger (2012).

\footnotetext{
${ }^{9}$ Em reservatórios de óleo que apresentem boa permeabilidade em todas as direções e ausência de capas de gás e água, o uso da técnica de perfuração horizontal não é essencial, visto que poços verticais convencionais podem atingir o mesmo nível de recuperação do reservatório à menores custos. Já em casos de reservatórios de baixa permeabilidade, ou em casos em que a presença de capas de gás e água confinada pode interferir nas taxas de recuperação, a perfuração horizontal se apresenta viável economicamente, compensando o custo de implantação com os valores de recuperação.
} 
O primeiro poço horizontal da história americana foi executado na região de Texon, no Texas, em 1929. No entanto, a técnica não se popularizou até a década de 1980, quando a tecnologia tornou esse tipo de exploração economicamente viável. Ainda assim, como grande parte da exploração por perfuração horizontal é realizada para reservatórios não convencionais em estágio de sobrepressão, a técnica não é eficaz quando utilizada isoladamente, sendo necessária a implantação de outra técnica exploratória que favoreça o fluxo de petróleo para o poço, i.e., o denominado fraturamento hidráulico.

\subsubsection{FRATURAMENTO HIDRÁULICO}

De acordo com FracFocus (2010), o fraturamento hidráulico consiste em uma técnica de recuperação de reservas, implantada uma vez que a perfuração foi concluída. A técnica corresponde à injeção de fluidos, sob condições de alta pressão, em reservatórios, criando pequenas fraturas na formação com a finalidade de permitir a passagem de petróleo (ou de água, no caso de exploração de aquíferos) para os poços exploratórios. O fluido pressurizado utilizado é basicamente constituído de água, areia e pequenas concentrações de compostos químicos. A liberação do fluido para o sistema ocorre de maneira similar a pequenas explosões, resultando no fraturamento do sistema devido à elevada pressão. As frações de areia (e/ou de grãos de hidróxido de alumínio) são responsáveis por manter a abertura das microfraturas para manter a continuidade do fluxo. Segundo Schlumberger (2012), as dimensões e a quantidade de fraturas são fatores decisivos na potencialização da produção de hidrocarbonetos, estas são classificadas como microfraturas (geralmente inferiores a $1 \mathrm{~mm}$ ), pelas quais o petróleo migra até o poço. A adição de compostos químicos (geralmente ácidos) é realizada para ajudar a iniciar o processo de microfraturamento da rocha devido o fenômeno de corrosão, além de influenciar na viscosidade do fluido a fim de facilitar sua penetração na formação. A técnica é bastante comum em explorações de gás de folhelho, CBM e BCG (Figura 24). 


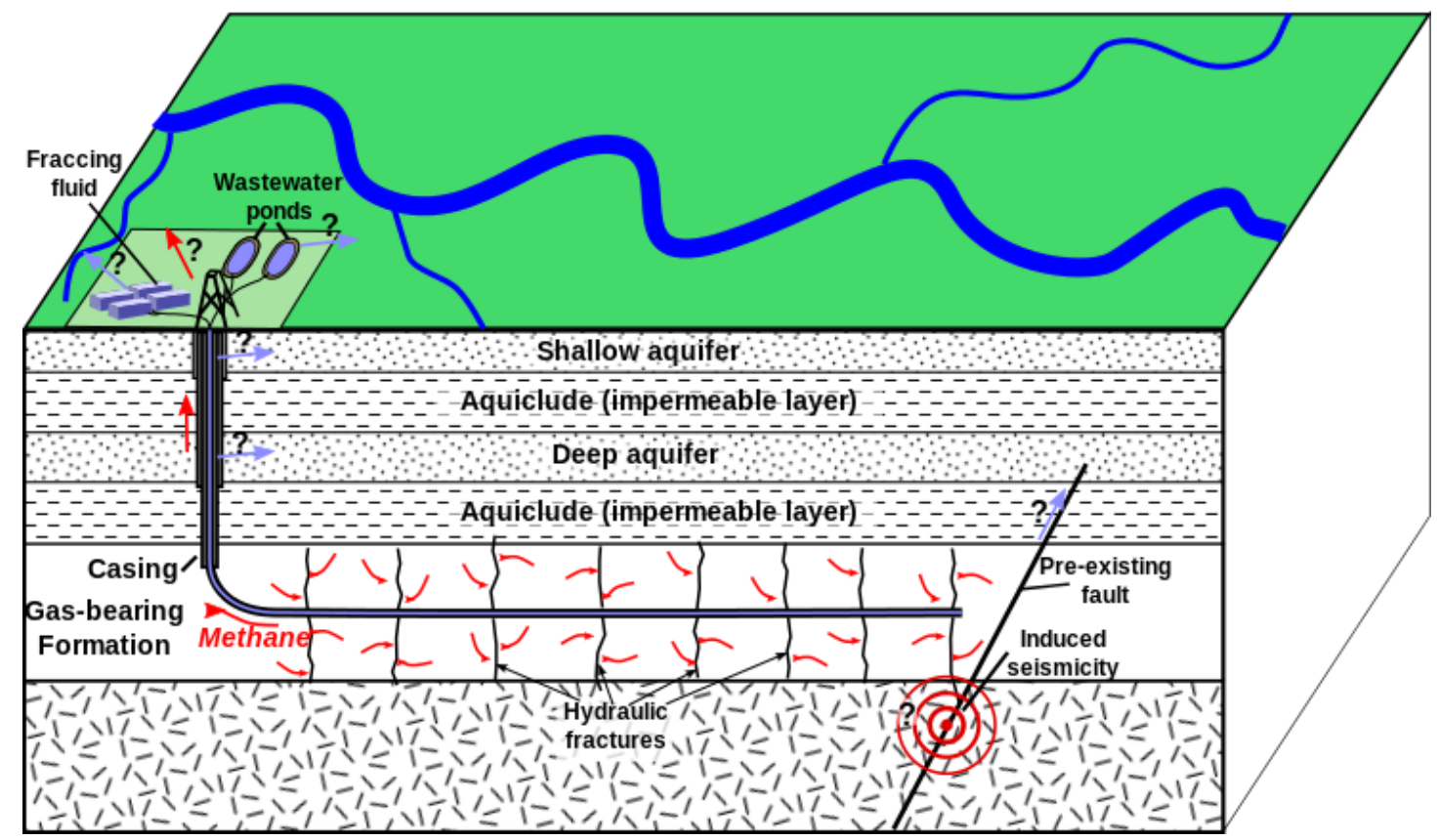

Figura 24 - Bloco diagrama representando o funcionamento da técnica de fraturamento hidráulico em associação à técnica de perfuração horizontal.

Fonte: Fracfocus (2010).

O fraturamento hidráulico é amplamente utilizado para potencializar a produção petrolífera, tanto em reservas convencionais como em reservas não convencionais. No entanto, o uso da técnica é essencial em depósitos não convencionais, onde a explotação de hidrocarbonetos só se torna economicamente viável devido o a implantação dessa técnica (geralmente associada à técnica de perfuração horizontal) em virtude de situações de sobrepressão em reservatórios. Investimentos e avanços tecnológicos têm aprimorado a técnica de fraturamento hidráulico, popularizando-a não apenas nos Estados Unidos, onde é a principal técnica de recuperação de reservas (Figura 25), mas também em escala global. 


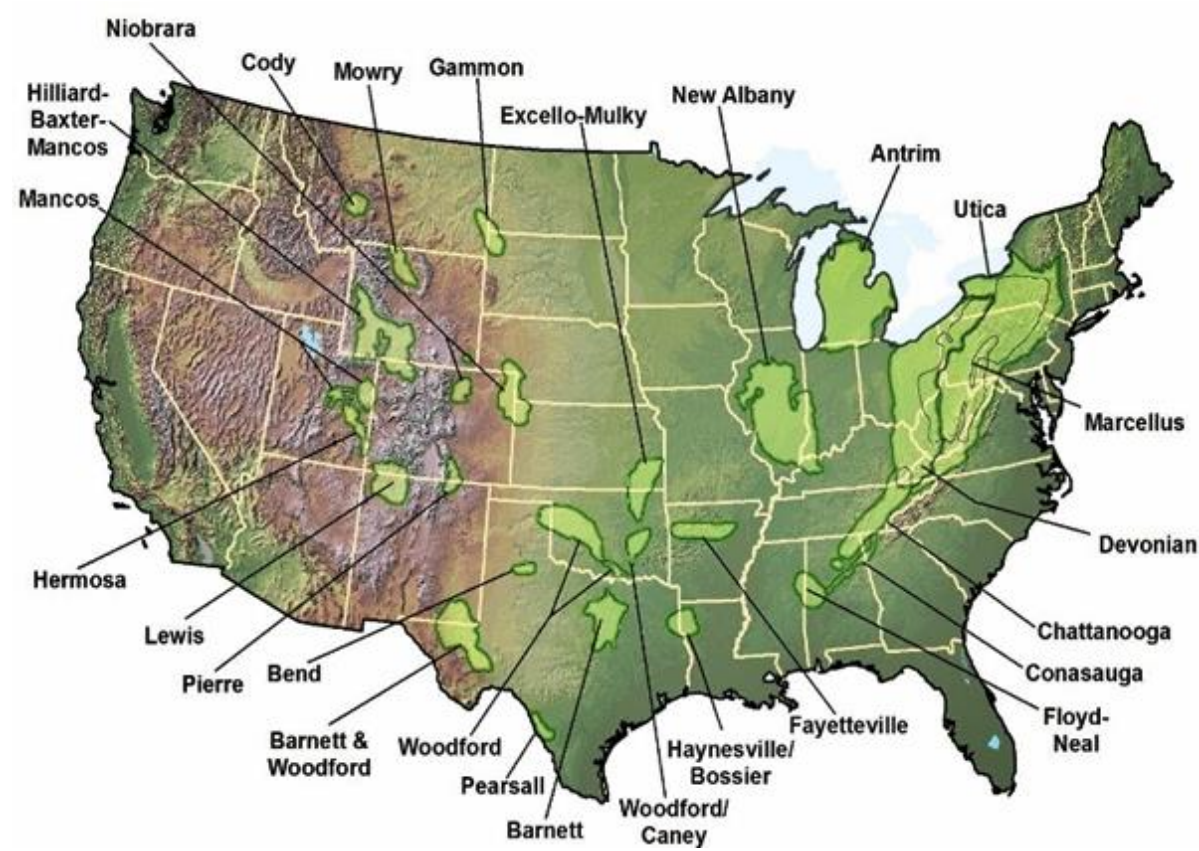

Figura 25 - Mapa dos Estados Unidos representando as principais áreas de utilização de fraturamento hidráulico. EIA (2012).

O primeiro experimento de fraturamento hidráulico foi realizado em 1947, e as primeiras aplicações comercialmente efetivas vieram pouco tempo depois, em 1949. O pesquisador Floyd Farris foi o pioneiro na utilização do fratumento hidráulico, no entanto, George P. Mitchell foi o responsável pelo significativo sucesso de implantação da técnica, já na década de 1990, sendo considerado o "pai do fracking”. De acordo com dados na EIA (2012), em 2010, 60\% da produção mundial de gás natural utilizada da técnica de fraturamento hidráulico, substituindo o uso de explosivos para a recuperação de hidrocarbonetos. Especialistas acreditam que, nos próximos dez anos, $80 \%$ dos poços de petróleo nos Estados Unidos utilizarão de fraturamento hidráulico para que continuem em operação (FracFocus, 2013).

A técnica ainda se apresenta pouco conhecida e ainda não utilizada no Brasil. No entanto, conforme o parecer da $12^{\mathrm{a}}$ Rodada de Licitações da ANP, a implantação da técnica foi permitida para a exploração de gás natural não convencional, sendo posteriormente vetada até o desenvolvimento de estudos mais detalhados por meio de uma moratória. Apesar da necessidade de utilização da técnica de fraturamento hidráulico para a produção de hidrocarbonetos não convencionais, opiniões controversas a respeito de possíveis impactos ambientais consequentemente associados, têm gerado polêmica quanto ao uso da mesma. 


\subsubsection{CONSEQUENNCIAS AMBIENTAIS}

Apesar das técnicas de perfuração horizontal e fraturamento hidráulico fazerem parte da história da indústria petrolífera nos Estados Unidos, polêmicas referentes á impactos ambientais causados a partir dessas técnicas têm ameaçado sua popularização no mercado mundial. Debates públicos entre o setor petrolífero e ambientalistas tem sido bastante presente no país e no mundo. No entanto, a veracidade quanto a esses desastres ambientais ainda não foi cientificamente comprovada.

Os principais potenciais impactos ambientais envolvidos são relacionados à contaminação de aquíferos e corpos hídricos superficiais. No entanto, segundo Mandalios (2013), o fraturamento hidráulico pode também resultar no fenômeno de subsidência do terreno (land subsidence), pequenos abalos sísmicos e até o colapso do mesmo. A polêmica acerca da implantação dessas técnicas também engloba a temática da explotação intensiva desses recursos hídricos: visto que o processo de fraturamento hidráulico necessita de grandes volumes de água para ser implantado, podendo potencialmente interferir na disponibilidade de água para abastecimento urbano. Além disso, a adição de compostos químicos, também característica dessa técnica exploratória, poderia atuar como potencial contaminante de água subterrânea e superficial (no caso de fluxo inverso no sistema); situação agravada no caso de ausência de tratamento adequado do fluido residual do processo (Figura 26) (Mandalios 2013).

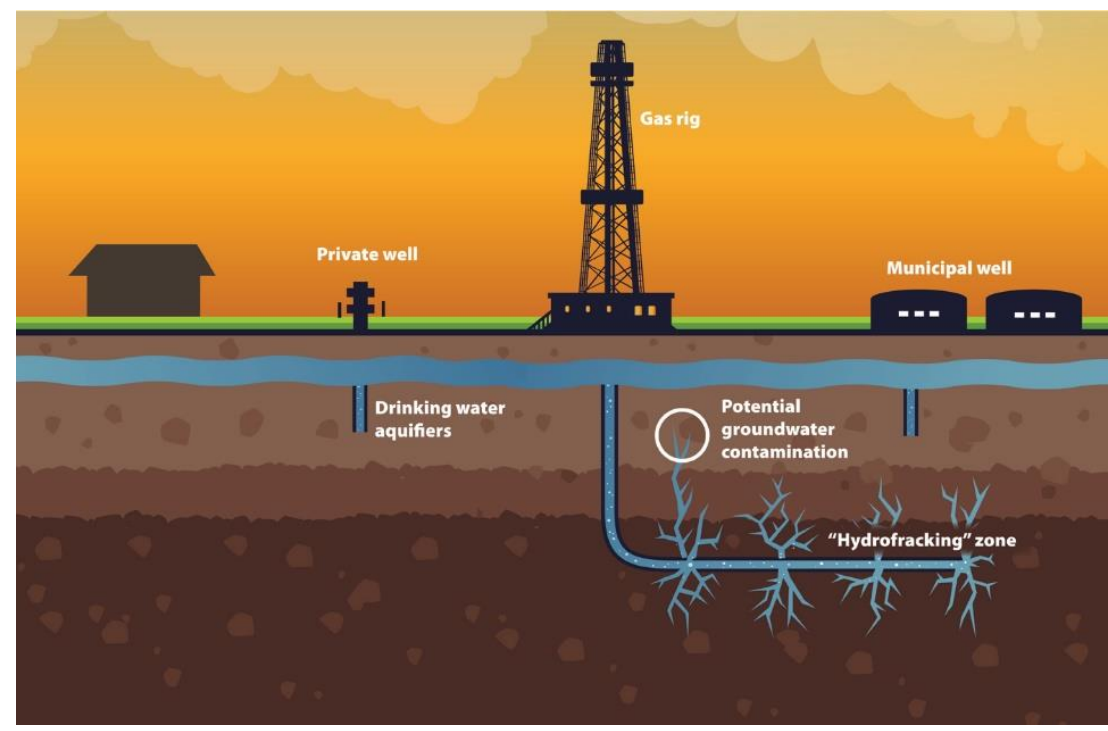

Figura 26 - Representação esquemática das técnicas de fraturamento hidráulico e perfuração horizontal e de seu respectivo impacto ambientai relacionado à contaminação de água subterrânea. Mandalios (2013).

De acordo com ambientalistas, além do uso intensivo de água, o fator mais preocupante é a composição química do fluido utilizado na técnica de fraturamento hidráulico. Segundo 
Werner et al (2014), o fluido de fraturamento é constituído por mais de 600 compostos químicos, incluindo concentrações de uranio, mercúrio, glicol de etileno, metanol de rádio, ácido hidroclorídrico e formoldeído, substancias bastante tóxicas ao organismo humano, com propriedades cancerígenas, além de prejudiciais ao meio ambiente. Além disso, segundo o autor, apenas cerca de 30 a $50 \%$ de fluidos residuais recebem tratamento, sendo despejados ao solo e representando potenciais fontes de contaminação de água subterrânea (por meio de infiltração) e superficial; além de liberar compostos voláteis tóxicos para a atmosfera. Diante dessa situação, alguns países aboliram o uso da técnica de fraturamento hidráulico.

O fraturamento hidráulico é motivo de controvérsia em todo o mundo. O método é permitido na Polônia e no Reino Unido, mas proibido na França e na Bulgária. Outros países europeus declararam moratória à técnica de extração, com o objetivo de realizar uma análise mais aprofundada sobre os potenciais impactos ambientais, como o caso da Irlanda, República Tcheca, Romênia, Alemanha e Espanha. A organização não governamental Greenpeace se posicionou oficialmente contra o método: instituição diz ter sérias preocupações com os impactos diretos e indiretos sobre a saúde individual e pública. Segundo a entidade, muitos desses impactos não são só locais, mas podem ser sentidos em níveis regionais e até mesmo globais (Deutsche Welle, 2013). No entanto, pode-se inferir que a resistência européia quanto à utilização de fraturamento hidráulico pode estar associada a fatores estratégicos e econômicos, tais como inviabilidade geológica de ocorrência dessas acumulações, ausência de investimento e infraestrutura requerida, além do fato da liderança norte americana no mercado potencialmente representar uma barreira econômica na indústria petrolífera internacional; representando o usual cenário onde questões ambientais são subalternas à política comercial.

Em contrapartida a organizações ambientalistas, a indústria petrolífera afirma que uso dessas técnicas viabiliza a exploração de recursos energéticos não convencionais, como o gás em folhelho, CBM e BCG, os quais representam fontes enérgicas mais limpas e que atuam na redução da emissão de gases geradores do efeito estufa, como o dióxido de carbono. Além disso, até o presente momento, não houve comprovação de contaminações de recursos hídricos por meio de fraturamento hidráulico e de perfuração horizontal; mesmo que se tenha conhecimento do potencial de contaminação, não foram encontradas concentrações expressivas de componentes tóxicos (Werner et al., 2014). São estes compostos químicos como: cloreto de amônia, óxido de magnésio, cloreto de sódio, ácido bórico, metanol, ácido fosfórico, ácido acético, dentre outros que também são amplamente utilizados para finalidades domésticas e industriais, tais como na indústria de cosméticos, na produção de detergentes e outros produtos de limpeza, produção de fertilizantes e alimentos. Além disso, sabe-se que esta relação de 
produtos químicos é utilizada para finalidades como: anticorrosivos, redutores de atrito, reguladores da viscosidade do fluido, redutores da espessura do fluido, na prevenção da precipitação de sais minerais e/ou de metais na tubulação; no ajuste do pH, na facilitação do fluxo do hidrocarbonetos, dentre outras finalidades essenciais ao processo de produção petrolífera; e que estão sendo progressivamente substituídos por compostos orgânicos, além de obrigatoriamente seguirem normas e especificações para a implantação dessa técnica exploratória (Tassinari, 2015).

De acordo com a revista Forbes (2012), em apenas cinco anos, os Estados Unidos atingiram $70 \%$ da proposta de redução de dióxido de carbono estabelecida pelo Protocolo de Kyoto em 1998, fato decorrente do avanço da exploração de fontes mais limpas de energia (boom da exploração de gás natural não convencional), não prevista em 1998 (Figuras 27 e 28).

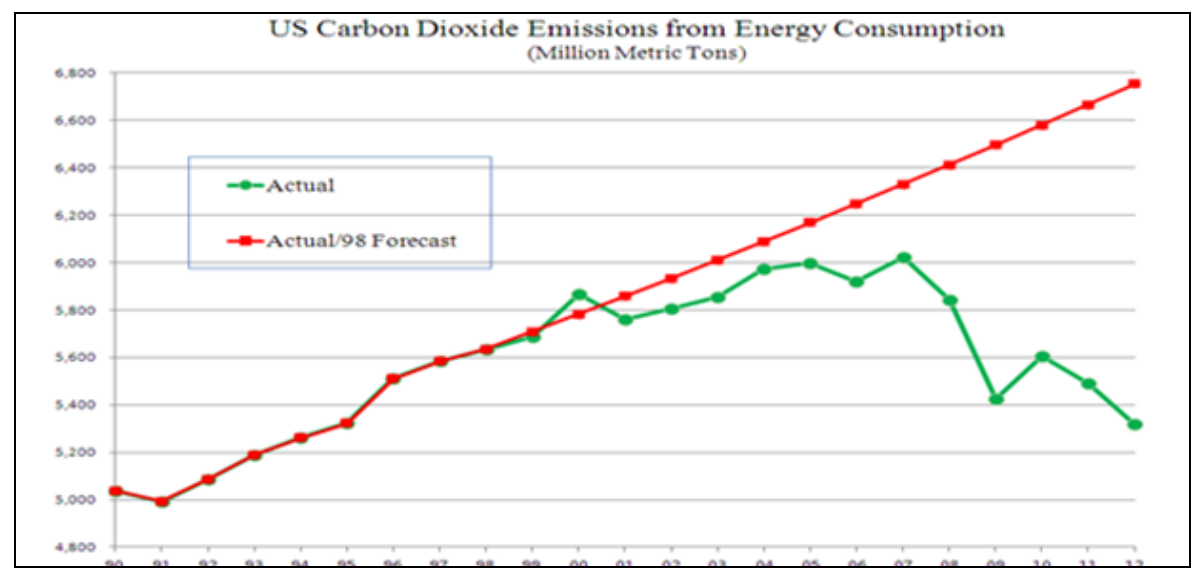

Figura 27 - Gráfico representando, em vermelho, a taxa de emissão de dióxido de carbono, prevista em 1998; e a taxa atual de emissão, em verde.

Fonte: Forbes (2012).

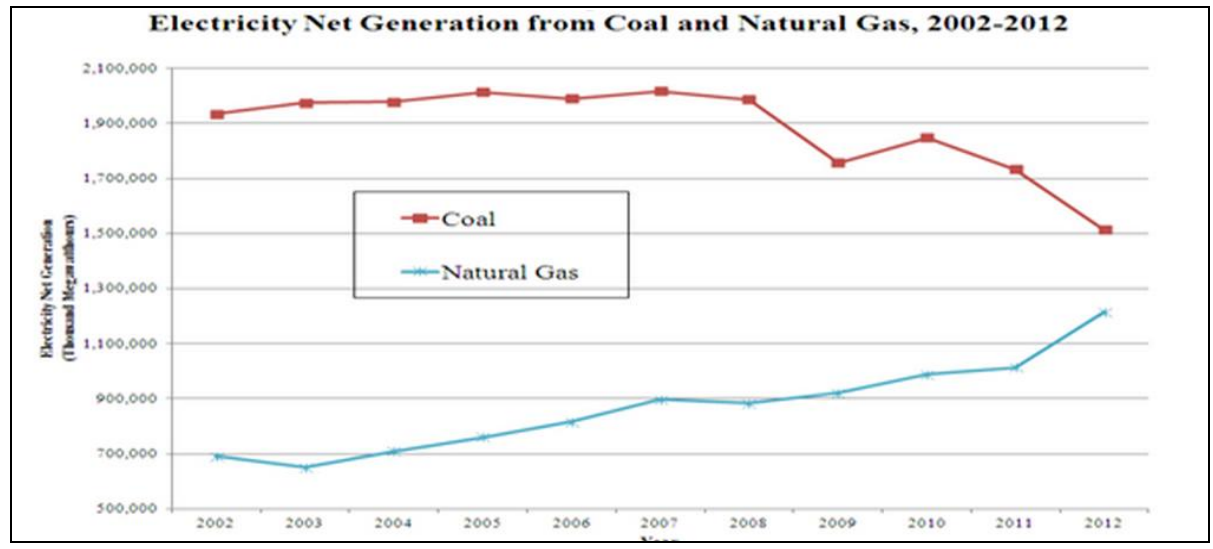

Figura 28 - Gráfico representando o recente declínio do uso de carvão mineral como fonte geradora de energia elétrica nos Estados Unidos, e o aumento do uso de gás natural como fonte energética, fator que implica na redução da emissão de poluentes.

Fonte: Forbes, 2012. 
Diante de uma sociedade ainda bastante dependente de combustíveis fósseis como geradores de energia, a questão ambiental deve ser bastante considerada. Apesar da polêmica quanto ao uso de técnicas não convencionais de exploração em virtude de impactos à saúde e ao meio ambiente, a necessidade de exploração desses recursos não pode ser ignorada. Diante dessa situação, é importante não apenas a consciência ambiental e a preocupação com a saúde humana, mas também a participação política para que regulamentações quanto à implantação dessas novas tecnologias, ao uso de poluentes e ao tratamento de rejeitos sejam implantadas.

Segundo Radovic (1997), o gás natural é um combustível ideal na relação custo/benefício; o gás natural possui uma composição simples e com alto potencial calorífico (1000 BTU/ft3 ou 24,000 BTU/lb), maior do que qualquer combustível fóssil. Quando comparado a outros recursos energéticos como petróleo e carvão, o gás natural requer pouco processamento para que seja utilizado, além de ser de fácil combustão e emitir menos poluentes que outras fontes não renováveis de energia. O recurso também requer menor consumo de água em sua exploração e produção, comparativamente à outras fontes energéticas, conforme relata a tabela 4:

Tabela 4 - Uso comparativo do consumo de água (galões) para geração de energia (BTU) dentre diversas fontes energéticas.

\begin{tabular}{l|cc|}
\hline Recurso Energético & $\begin{array}{c}\text { Consumo de Água } \\
\text { (galões/BTU) }\end{array}$ & $\begin{array}{c}\text { Consumo médio de } \\
\text { água (galões/BTU) }\end{array}$ \\
\hline Gás em Folhelho & $1-6$ & 3 \\
Nuclear (enriquecimento de urânio) & $8-14$ & 11 \\
Petróleo Convencional & $8-20$ & 14 \\
Synfuel (gaseificação do carvão) & $11-26$ & 18 \\
Carvão Mineral & $13-32$ & 23 \\
Óleo em Folhelho & $22-56$ & 39 \\
Areias Betuminosas & $27-68$ & 47 \\
Etanol (a partir de milho) & $2.510-29.100$ & 15.805 \\
Biodiesel (a partir de soja) & $14.000-75.000$ & 44.500
\end{tabular}

Fonte: EIA (2014) apud Tassinari (2015). 
Nesse contexto, setores da economia, indústria e meio ambiente passam a ser beneficiados com o uso de gás natural como fonte de energia. Sendo assim, investimentos em estudos e tecnologias têm sido bastante realizados, não apenas nos Estados Unidos, mas em todo o mundo com a finalidade de incentivar a exploração desse recurso relativamente mais limpo e eficaz.

\section{CARACTERIZAÇÃO DE CAMPOS PRODUTORES DE GÁS NATURAL NÃO CONVENCIONAL}

A geoquímica orgânica corresponde a uma ferramenta datada do início da década de 1970, a qual utiliza princípios químicos para o estudo da origem, migração, acumulação, exploração e produção de petróleo, assim como na assistência à resolução de consequências ambientais tais como contaminações e poluição. A geoquímica orgânica pode ser dividida em: geoquímica orgânica molecular, que se restringe à fração betume (solúvel em solventes orgânicos) através da análise de biomarcadores, compostos aromáticos e compostos polares ricos em nitrogênio, enxofre e oxigênio (fração NSO); e geoquímica orgânica não-molecular, que caracteriza a fração de querogênio das rochas sedimentares. Técnicas de caracterização geoquímica de rochas geradoras de hidrocarbonetos analisam a quantidade, qualidade e o nível de maturação da matéria orgânica presente. Com a finalidade de obter uma análise mais completa, são implantadas técnicas petrográficas de avaliação ótica, tais como: reflectância da vitrinita, fluorescência da liptinita, índice de alteração e coloração de esporos, acritarcas e microfósseis; e técnicas geoquímicas, como: parâmetros de pirólise Rock-Eval, conteúdo de carbono orgânico total (COT), hidropirólise e caracterização de biomarcadores. Rochas geradoras podem ser classificadas de acordo com a quantidade máxima de betume que pode ser extraído, em diclorometano, expresso em \% (m/m) conforme a Tabela 5. (Azevedo da Silva, 2007).

Tabela 5. Relação percentual de betume e sua classificação em relação à quantidade de matéria orgânica presente em rochas geradoras de hidrocarbonetos.

\begin{tabular}{c|c}
\hline Quantidade de Matéria Orgânica & Fração Orgânica ou Betume (\% em massa) \\
\hline Pobre & $\leq 0,05$ \\
Razoável & $0,05-0,1$ \\
Boa & $0,1-0,2$ \\
Muito Boa & $\geq 0,2$ \\
\hline
\end{tabular}

Fonte: Modificado de Azevedo da Silva (2007).

Uma vez realizada a análise da quantidade de matéria orgânica, parâmetro inicial para a classificação de folhelhos, a análise geoquímica é incorporada à análise petrofísica e 
diagenética da bacia em geral, prosseguindo até atingir o nível de detalhamento exigido. Para o presente estudo, com base em dados bibliográficos de Andrews (2013) e o Serviço Geológico dos Estados Unidos (USGS), os seguintes critérios foram determinados como essenciais na classificação e determinação de campos produtores de shale gas:

Os processos de geração e preservação de petróleo são principalmente fundamentados no nível de maturação do hidrocarboneto e no tipo de matéria orgânica contida nas rochas geradoras (folhelhos), parâmetros cuja identificação é realizada por meio das seguintes técnicas de caracterização geoquímica:

\section{Carbono Orgânico Total (COT\%)}

Dentre as características geoquímicas essenciais à geração de hidrocarbonetos, a quantificação da matéria orgânica é, geralmente, a primeira análise a ser realizada para a determinação desse potencial em rochas geradoras de petróleo. O processo de medição da quantidade de matéria orgânica presente na rocha é realizado através do teor de carbono orgânico total (COT), expresso em forma percentual em relação ao estrato seco; parâmetro o qual representa as condições de formação e preservação do conteúdo orgânico no ambiente deposicional (Azevedo da Silva, 2007). A quantidade de matéria orgânica medida engloba tanto a fração insolúvel (querogênio) quanto a solúvel em solventes orgânicos (betume). O procedimento experimental dessa análise consiste, inicialmente, no tratamento da amostra: esta é pulverizada e em seguida diluída em ácido clorídrico, a fim de liberar o teor de carbono inorgânico na forma de carbonato, gerado a partir da interação com o ácido. Posteriormente, a amostra é submetida à um processo de combustão, onde é medido o teor de $\mathrm{CO}_{2}$ resultante desse processo, representante do teor de carbono orgânico da amostra. Em média, os valores de COT adequados à geração de hidrocarbonetos são em torno de 2,0\%, sendo valores mínimos aceitáveis de 1,0\% para folhelhos betuminosos e de $0,5 \%$ para folhelhos carbonosos (Tabela 6 ) (Azevedo da Silva, 2007).

Tabela 6 - Classificação do potencial petrolífero de rochas geradoras em função do teor de COT (\%).

\begin{tabular}{c|c|}
\hline Potencial de Geração de Hidrocarbonetos & COT $(\boldsymbol{\%})$ \\
\hline Baixo & $0-0,5$ \\
Médio & $0,5-1,0$ \\
Alto & $1,0-2,0$ \\
Muito Alto & $2,0-4,0$ \\
Excelente & $>4,0$
\end{tabular}

Retirado de Azevedo da Silva (2007).

\section{Pirólise Rock-Eval}


A taxa de maturação da matéria orgânica é outro parâmetro fundamental à geração de hidrocarbonetos, sendo esta medida por meio da técnica pirólise Rock-Eval. Esta técnica simula, em condições laboratoriais, os processos naturais de metagênese e catagênese pelos quais a rocha foi submetida, determinado o estágio de maturação em que se encontra a matéria orgânica presente. A implantação da técnica consiste, inicialmente, no superaquecimento de amostras, sem a presença de oxigênio para que não ocorra combustão. As amostras são submetidas à faixas de temperatura que variam entre 25 e $600^{\circ} \mathrm{C}$. Durante esse processo de aquecimento, ocorre a liberação de frações de hidrocarbonetos livres presentes nas amostras, além de gás carbônico $\left(\mathrm{CO}_{2}\right)$, ambos gerados em decorrência do craqueamento térmico do querogênio. A taxa de liberação desses gases é medida por meio de detectores de ionização, os quais registram essa liberação por meio de um pirograma, no qual são observados três diferentes picos: $S_{1}, S_{2}$ e $S_{3}$, que serão analisados em estudos geoquímicos (Figura 29).

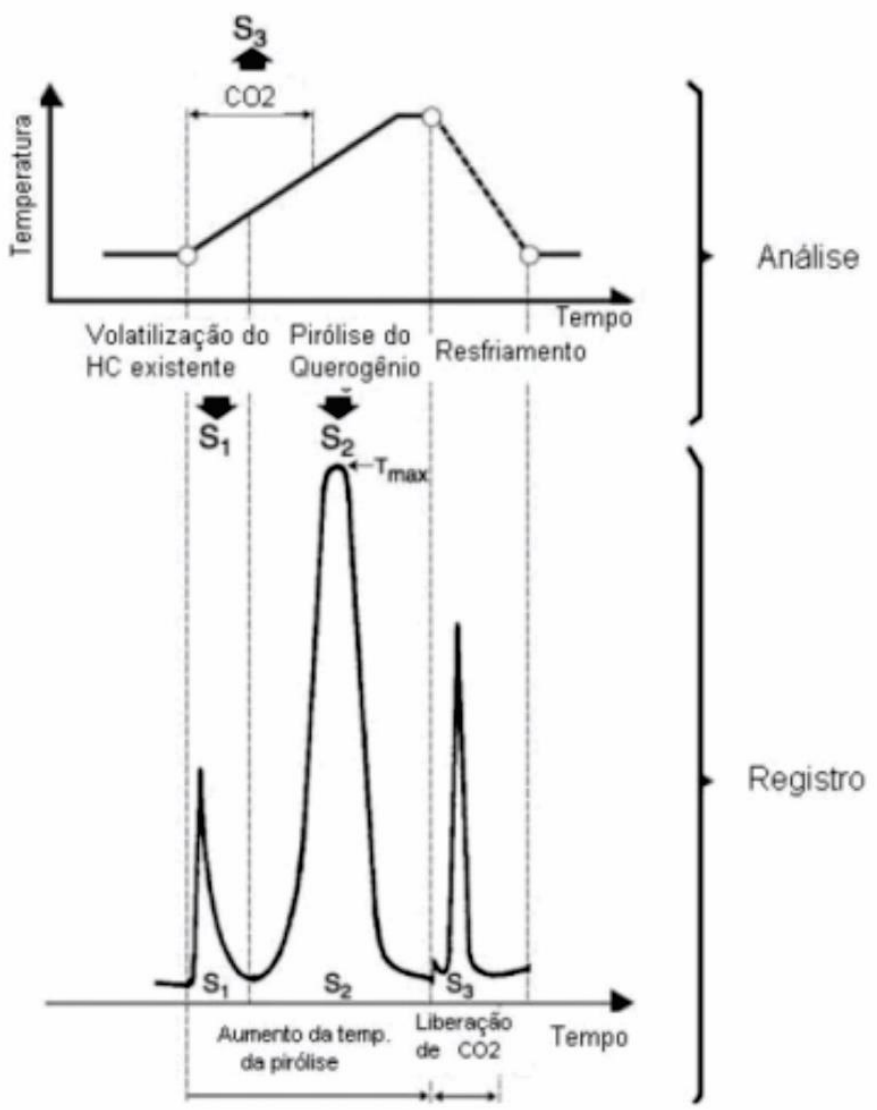

Figura 29 - Representação do ciclo de análise e exemplo de um pirograma obtido a partir de análise RockEval.

Fonte: Azevedo da Silva (2007).

$\mathrm{O}$ pico $\mathrm{S}_{1}$ representa a quantidade (em $\mathrm{mgHC} / \mathrm{g}$ rocha) de hidrocarbonetos livres (betume), fração solúvel da matéria orgânica em solventes orgânicos. $O$ pico $S_{2}$ representa, na mesma unidade, a quantidade de hidrocarbonetos liberados pelo craqueamento térmico do 
querogênio, sendo assim denominado o potencial gerador; ou seja, a quantidade de petróleo que a rocha analisada teria capacidade de gerar caso submetida às condições adequadas de soterramento, pressão e temperatura. Já o pico $S_{3}$ corresponde à quantidade de dióxido de carbono $\left(\mathrm{CO}_{2}\right)$ liberado ao longo desse processo de craqueamento (em mg CO $2 / g$ Rocha). Além da medição dos picos, interpretações relacionadas também são requeridas: com a progressiva conversão do querogênio em petróleo, ocorre também a progressiva redução do potencial gerador $\left(\mathrm{S}_{2}\right)$ e o associado aumento na quantidade de hidrocarbonetos livre $\left(\mathrm{S}_{1}\right)$, por isso é utilizada a relação $S_{1} /\left(S_{1}+S_{2}\right)$, denominada Índice de Produção (IP) como um indicador do avanço no processo de geração e do nivelo de maturação da matéria orgânica presente na rocha (Azevedo da Silva, 2007).

Com base nos resultados da pirólise Rock-Eval, uma avaliação semi-quantitativa do potencial gerador de uma rocha pode ser realizada, sendo $S_{1}$ a representação do potencial inicial de geração da rocha (fração de geração original) e $S_{2}$ a representação do potencial residual. Desta forma, a relação $S_{1}+S_{2}$, expressos em $\mathrm{mg}$ de $\mathrm{HC} / \mathrm{g}$ rocha, corresponde ao potencial total de geração de hidrocarbonetos de um rocha, baseada no tipo e quantidade de matéria orgânica presente. A partir dessa análise, a seguinte classificação de rochas geradoras foi determinada (Azevedo da Silva, 2007): rochas com potencial gerador $\left(S_{1}+S_{2}\right)$ inferior a $2 \mathrm{mg}$ de $\mathrm{HC} / \mathrm{g}$ de rocha $(<2000$ ppm), não são consideradas rochas geradoras de óleo, mas apresentam algum potencial para gás natural; rochas com potencial entre 2 e $6 \mathrm{mg} \mathrm{de} \mathrm{HC/g}$ de rocha (entre 2000 e 6000 ppm) são consideradas rochas com potencial moderado para geração de petróleo; e rochas com potencial superior a $6 \mathrm{mg}$ de $\mathrm{HC} / \mathrm{g}$ de rocha (> $6000 \mathrm{ppm}$ ) são consideradas rochas geradoras de petróleo, com bom potencial de geração.

Além da avaliação dos picos $S_{1}, S_{2}$ e $S_{3}$, também é avaliada a temperatura em que ocorre o máximo da geração de hidrocarbonetos, a partir do craqueamento do querogênio, refletindo o máximo da evolução térmica em que a rocha esteve submetida, propriedade denominada Tmáx. Em geral, amostras com valores de Tmáx na ordem de $<435$ a $440^{\circ} \mathrm{C}$ são consideradas rochas imaturas, e apresentam Índice de Produção (IP) $<0,1$; enquanto que rochas maturas, que atingiram valores de pico de geração, apresentam valores de Tmáx entre 445 e $450^{\circ} \mathrm{C}$ e IP na ordem de 0,4 (Azevedo da Silva, 2007).

Outros parâmetros também podem ser determinados a partir da pirólise Rock-Eval, como o Índice de Hidrogrênio (IH) e Índice de Oxigênio (IO), analisados com a finalidade de se determinar o tipo de matéria orgânica presente e seu grau de preservação: de modo geral, a matéria orgânica de origem terrestre é mais pobre em hidrogênio e rica em oxigênio enquanto que matéria orgânica algácea é geralmente rica em hidrogênio. Querogênios do tipo III, 
essencialmente terrestre, caracterizam-se por baixos valores de IH (geralmente < 300 $\mathrm{mgHC} / \mathrm{gCOT}$ ) e elevados valores de IO (geralmente superiores a $100 \mathrm{mgCO}_{2} / \mathrm{gCOT}$ ). Já querogênios do tipo II, de origem marinha, apresentam valores de IH na ordem de 400 a 700 $\mathrm{mgHC} / \mathrm{gCOT}$, e do tipo I, de origem lacustre, IH geralmente superior a 600-700 mgHC/gCOT; ambos os tipos II e I apresentam baixos valores de IO (inferiores a $100 \mathrm{mgCO}_{2} / \mathrm{gCOT}$ ). Esses valores são correspondentes à rochas geradoras imaturas, visto que, ao longo do processo de maturação e da análise Rock-Eval, os valores de IH e IO tendem à zero (Azevedo da Silva, 2007). Nesse contexto, os três tipos básicos de querogênio (tipos I, II e III) podem ser identificados a partir da integração dessas informações: o IH é obtido a partir da razão $\mathrm{S}_{2} / \mathrm{COT}$ e expresso em mg HC/g COT, e o IO a partir da razão $\mathrm{S}_{3} / \mathrm{COT}$ e expresso em mg $\mathrm{CO}_{2} / \mathrm{g}$ COT (Azevedo da Silva, 2007).

\subsection{Parâmetros Adotados}

$\mathrm{O}$ método de pesquisa da presente dissertação de mestrado inclui o levantamento dos parâmetros geológicos comparativos estabelecidos pelo U.S.Geological Survey (USGS) e por demais fontes na literatura para a determinação de campos produtores de shale gas (shale plays) (USGS, 2013; Andrews, 2013; Azevedo da Sila, 2007); visando estabelecer quais os parâmetros mais adequados e que serão adotados neste trabalho para a análise da viabilidade geológica na Bacia do Paraná para a ocorrência desse recurso. Nesse contexto, foram levantados dados referentes à geologia, geoquímica orgânica e petrofísica de folhelhos, os quais foram sumarizados em tabela e são a base para o estudo comparativo entre as principais províncias de shale gas.

\subsubsection{Parâmetros Geológicos}

Mineralogia e Conteúdo de Argila (\%): O conteúdo de argila deve ser inferior a 35\% para facilitar o fraturamento hidráulico. Segundo Andrews (2013) o conteúdo de sílica deve ser superior a $30 \%$ e frações carbonáticas também devem estar presentes.

Espessura da Camada: Camadas de folhelho de espessura moderada são consideradas ideais (acima de $50 \mathrm{ft}$ ou 15m). Acreditava-se que maiores espessuras fossem favoráveis à acumulações de gás de folhelhos, entretanto, estudos reaizados pela USGS apontam que camadas muito espessas tendem a resultar em acumulações do tipo BCG (basin centered gas ou tight gas) ao invés de shale gas. 
Profundidade: A profundidade em que se encontra a camada de folhelho deve ser superior a $5000 \mathrm{ft}$ (ou 1500m). Profundidades menores geralmente tendem a resultar em fluxo reduzido na produção do gás natural em virtude do gradiente de pressão.

Tectônica e diagênese da Bacia: Preferencialmente bacias sedimentares de grande escala (extensão) e estáveis (intracratônicas), sem elevada complexidade tectônica ao longo de sua história evolutiva (baixo grau de fraturamento e falhamento). Os poços produtores devem ser perfurados distantes de falhas e fraturas.

\subsubsection{Parâmetros Geoquímicos}

Teor de carbono orgânico (\% COT): De acordo com Andrews (2013), os valores adequados de carbono orgânico total (COT) para gás natural não convencional em folhelhos devem ser superiores a $2 \%$ (Charpentier \& Cook, 2011), a $4 \%$ (Lewis et.al.2004), ou até mesmo a $1 \%$ (Jarvie, 2012). Segundo USGS (2013), a média entre os principais campos produtores de shale gas nos Estados Unidos é entre 0.93-5.34\% COT.

Tipo de Querogênio: O querogênio deve ser tipo I ou tipo II. Sendo o tipo II mais adequado segundo Andrews (2013), USGS (2013).

Índice de Hidrogênio (IH): deve ser preferencialmente superior a $250 \mathrm{mg} / \mathrm{g}$. Andrews (2013) destaca a importância do dado original de IH e não de valores recentes, os quais descaracterizam a análise.

Maturidade Termal/Gradiente Geotérmico: O folhelho deve apresentar maturidade termal para gás natural (janela de gás termogênico), sendo valores ideais de reflectância de vitrinita $\left(\mathrm{R}_{\mathrm{o}}\right)$ entre 1.1 e $3.5 \%$ ou preferencialmente entre 1.75 e $3 \%$.

\subsubsection{Parâmetros Petrofísicos}

Valores de Raio-Gama: Radiação Gama elevada representa um indicativo de elevado conteúdo de matéria orgânica. Dessa forma, valores elevados de raio gama são ideias para 
ocorrência de shale gas: tipicamente entre 150 e 200 API.

Porosidade (\%): Tipicamente entre 4 a 7\%. Necessariamente inferior a $15 \%$.

Saturação em Gás: O gás natural deve estar presente tanto livre (na matriz e fraturas) e adsorvido à matéria orgânica. A saturação ideal é entre 60 e 200 bcf por sessão geológica.

\section{MODELO GEOLÓGICO DESCRITIVO-COMPARATIVO}

A partir de estudos dos campos petrolíferos comprovadamente geradores e produtores de gás natural não convencional e da análise dos fatores condicionantes à ocorrência desse recurso, foi realizado o levantamento e combinação dos parâmetros geológicos, geoquímicos e petrofísicos considerados essências à essa condição. Essa compilação está demonstrada na seguinte tabela descritiva-comparativa para a determinação de potencial para gás natural não convencional em folhelhos (Tabela 7).

Tabela 7. Modelo Descritivo dos principais parâmetros analisados na avaliação da viabilidade geológica para a ocorrência de acumulações de gás natural não convencional em folhelhos.

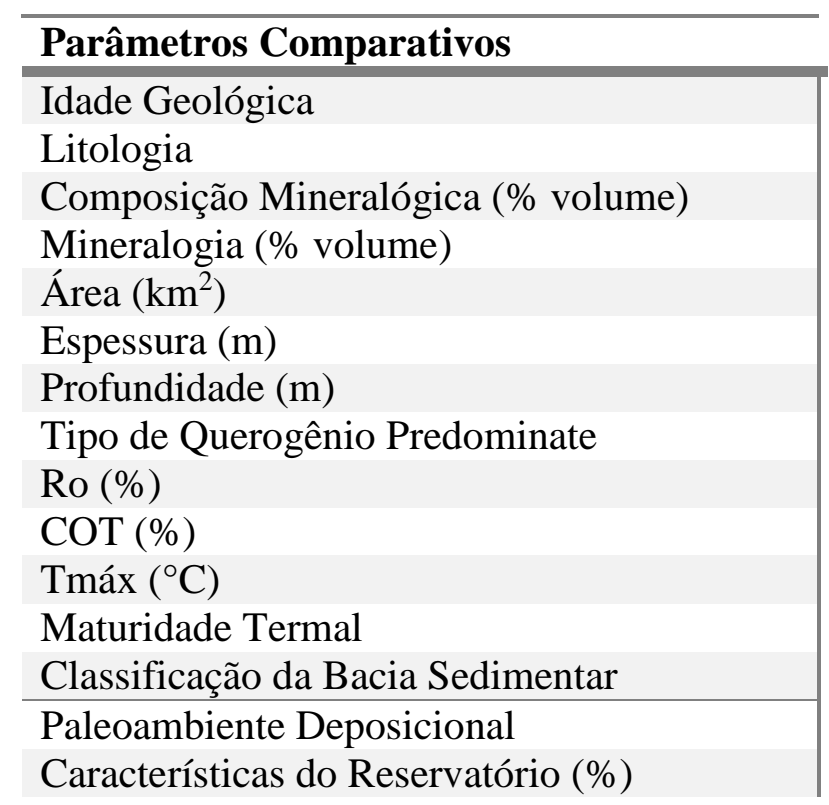

Fonte: Modificado de Azevedo da Silva (2007), Andrews (2013) e USGS (2013).

Uma vez identificados os parâmetros condicionantes à ocorrência de gás natural não convencional, estes foram analisados nos principais campos produtores de shale gas: os campos norte-americanos de Marcellus, Barnett e Eagle Ford. Estes campos foram adotados para estudo devido sua relevância na produção desse recurso, sendo estes os maiores produtores de gás natural não convencional no período de 2008 a 2014 (Norton Rose Fulbright, 2013) e pioneiros 
na produção desse recurso em escala comercial, além de serem adotados como referência de padrões geológicos, geofísicos e de engenharia de reservatórios para a determinação de campos de shale gas pelo Serviço Geológico dos Estados Unidos (USGS). Nesse contexto, esses principais campos produtores foram analisados com a finalidade do desenvolvimento de estudos comparativos entre estes e potenciais campos brasileiros por meio de analogias.

\subsection{Principais Campos Produtores de Gás Natural Não Convencional}

\subsubsection{MARCELLUS SHALE}

O Campo Marcellus pertence à formação homônima e está situado na porção nordeste dos Estados Unidos, na região das montanhas Appalache (Figura 30). O campo de Marcellus apresenta um potencial recuperável entre 30 e 300 Tcf de gás natural, combinado à vantagem de aproximação de grandes centros consumidores no país. A litologia é constituída por folhelho negro rico em matéria orgânica datado do Devoniano (aproximadamente $390 \mathrm{Ma}$ ), sendo sua deposição associada à orogenia Acadian (Lee et.al.,2011).

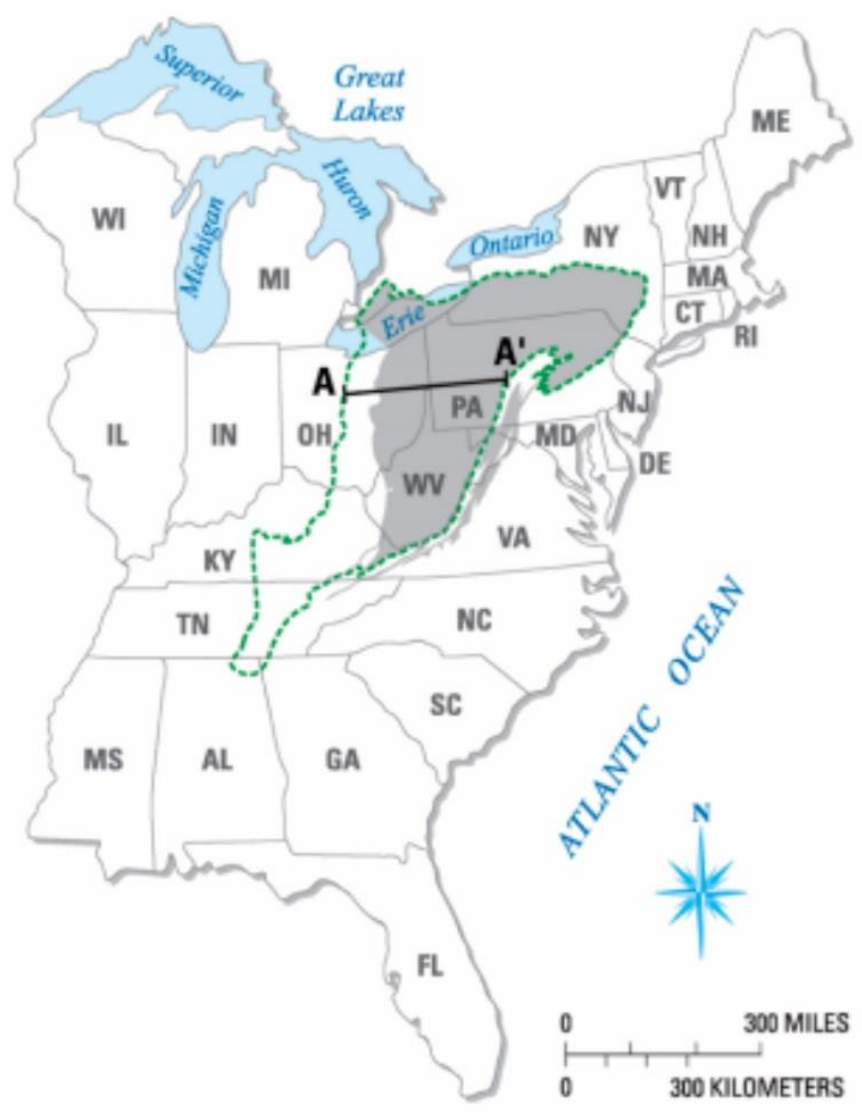

Figura 30 - Mapa representativo da disposição geográfica da formação geológica Marcellus, Bacia Appalachian. 
Fonte: Lee (et al., 2011).

O folhelho Marcellus foi originalmente reconhecido como rocha geradora de hidrocarbonetos dentro de sistemas petrolíferos convencionais do Devoniano superior e Carbonífero inferior (Mississipiano), os quais vêm sido explorados desde 1821. A exploração de hidrocarbonetos na bacia Appalachiana, onde se apresenta inserido, foi intensificada entre 2004-2005 devido ao boom na produção de gás natural não convencional nos Estados Unidos (shale boom). Baseada em aspectos exploratórios utilizados no campo de Barnett, no Texas, a exploração de Marcellus foi inicialmente bem sucedida, com recuperação de volumes consideráveis de hidrocarbonetos, principalmente gás natural nas porções leste e nordeste da bacia, onde se encontra o principal campo de produção de shale gas na região (estados de West Virgínia, Pennsylvania e New Yrok) (Bruner \& Smosna, 2011) (Durham, 2008). Este campo produtor (shale play) é delimitado pelas estruturações de Allegheny, ao leste, de Adirondack, a nordeste, e de Waverly ou arco de Cisalhamento a oeste. Na porção central do campo produtor, a formação Marcellus chega a apresentar 50 pés (aproximadamente 15 metros) de espessura a qual se prolonga por, aproximadamente $50.000 \mathrm{mi}^{2}\left(129 \mathrm{~km}^{2}\right)$, porção de maior potencial para produção e geração de hidrocarbonetos. Devido à localização dessas porções, atividades de exploração, produção, e atividades regulatórias estão principalmente concentradas nos estados de West Virgínia, Pennsylvania e New York.

A Bacia Appalachiana é caracterizada como uma bacia sedimentar assimétrica de antepaís formada ao longo de 200 milhões de anos. Ao longo de seu período de formação, a bacia esteve submetida à três diferentes orogenias: Orogenia Taconic, datada do Ordoviciano superior e que representa o processo colisional entre as placas tectônicas de Laurentia e Laurussia e um sistema de arcos de ilhas oceânicas; Orogenia Acadian, do Devoniano ao Mississipiano inferior e resultante da colisão entre Laurentia e uma placa continental de menor escala (Avalonia, Baltica ou Armorica); e Orogenia Allegheny, do Pennsylvaniano ao Permiano, gerada a partir da convergência entre Laurentia e Gondwana e a consequente formação de Pangea. A reconstrução paleogeográfica da bacia indica que este se encontrava submersa na porção atualmente equivalente desde o estado de New York à Georgia, o que promoveu a acumulação de folhelhos negros ao longo da bacia, sendo o folhelho Marcellus o mais antigo e mais profundamente localizado na bacia (apesar de se apresentar localmente sobreposto ao folhelho Needmore). Desde sua deposição e soterramento, o folhelho Marcellus tem sido sujeitado à intensa atividade de deformação tectônica na bacia, principalmente associados à Orogenia Allegheny. Atualmente a bacia Appalachian apresenta disposição no 
sentido nordeste-sudoeste e seu eixo estrutural se apresenta a cerca de 6000 pés de profundidade abaixo do nível do mar. Os estratos referentes ao período Devoniano, como o folhelho Marcellus, apresentam mergulho estrutural no sentido leste, com uma média de 55 pés por milha a partir do Arco de Cincinnati, em Ohio, e se apresentando em profundidade de carca de 10.000 pés (cerca de 3.000 metros) na porção central do estado de Pennsylvania (Bruner \& Smosna, 2011).

O folhelho Marcellus, juntamente com a formação sedimentar sobressequente, Mahantango, constitui o grupo Hamilton, datado do Devoniano médio (períodos Eifeliano e Givetiano). O folhelho apresenta coloração variante entre cinza, marrom escuro e preta, composição carbonosa e intercalação com finas camadas de calcário e concreções carbonáticas, além de elevado grau de radioatividade em virtude de seu conteúdo rico em matéria orgânica. As camadas de calcário são fossilíferas e o folhelho se apresenta mineralogicamente rico em pirita, principalmente nas porções inferiores da formação. Sua espessura varia entre 140 a 660 pés (660 pés na porção nordeste da Pennsylvania, a qual reduz drasticamente para 200 pés nas direções oeste e sudoeste do estado, e para 140 pés ou menos em West Virgínia e Ohio; sendo, respectivamente 200, 60 e 42 metros de espessura) (Boyce, 2009 apud Bruner \& Smosna, 2011). Os limites geográficos da formação Marcellus são erosionais em todas as direções (Figura 31) (Bruner \& Smosna, 2011).

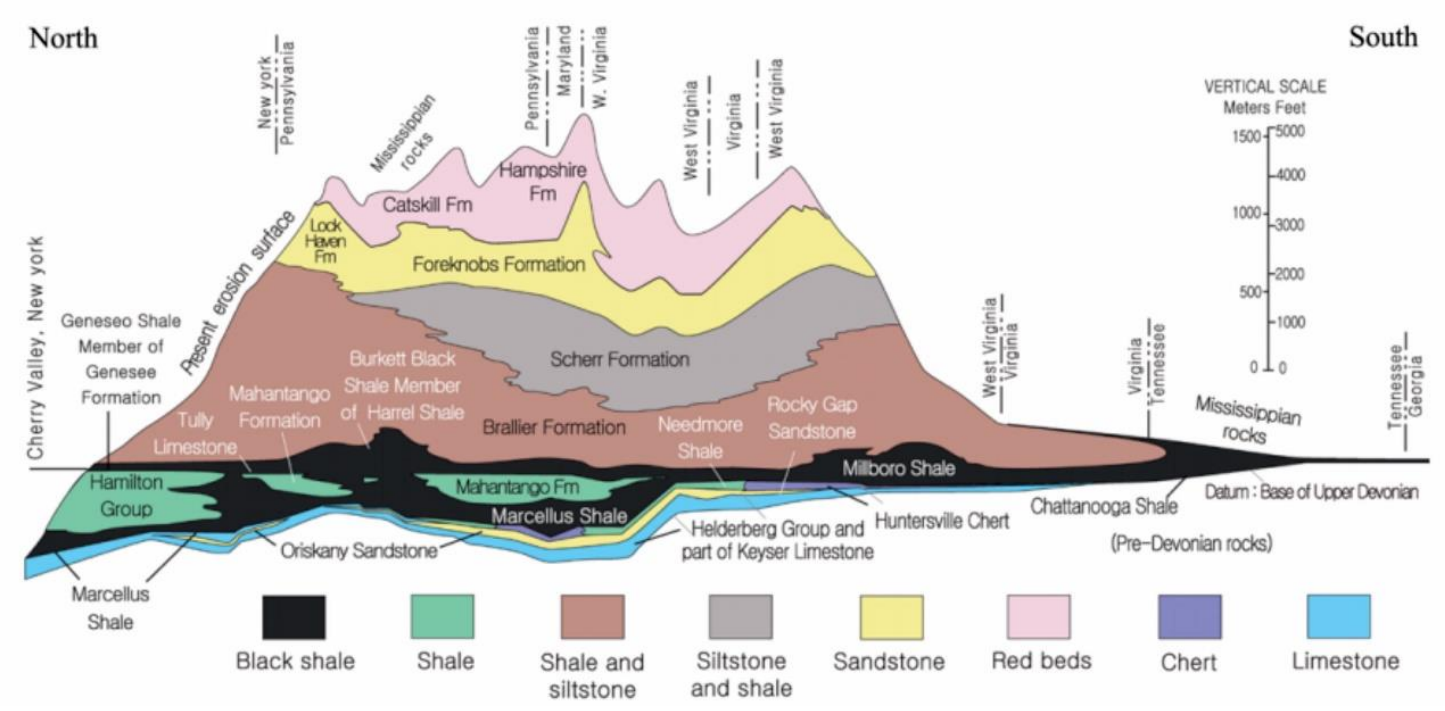

Figura 31 - Sessão estratigráfica representativa da formação geológica Marcellus, Bacia Appalachian. Fonte: Lee (et al., 2011).

Com base na análise de afloramentos realizada por Bruner \& Smosna (2011), amostras do folhelho Marcellus coletadas na porção oeste de New York indicam a subdivisão da 
formação em três diferentes membros estratigráficos: Union Springs, Cherry Valley e Oatka Creek. O membro inferior, Union Springs, corresponde a folhelhos de coloração cinza a preta que se caracterizam por sua leve foliação, composição rica em pirita, carbonato e matéria orgânica. Estratos de siltito também estão presentes dentre as camadas, principalmente na porção inferior do pacote. Baseada em análise de mapas de isópacas, a espessura do membro foi determinada em torno de 60 pés (18 metros), podendo atingir 150 pés (45 metros) no nordeste da Pennsylvania e 20 pés (6 metros) em Ohio. O membro intermediário, Cherry Valley, corresponde a um carbonato de granulometria fina com intercalações de folhelho calcítico. Localmente estão presentes nódulos de barita. A formação também é denominada de Purcell, incialmente descrita em West Virgínia, no entanto, alguns autores as consideram unidades diferentes. A espessura do membro varia entre 50 a 100 pés (15 a 30 metros). O membro superior é o denominado Oatka Creek e se apresenta subdividido em duas subunidades: uma subunidade basal de folhelhos negros (semelhantes aos do membro Union Springs, porém com valores diferenciados de raio-gama); e outra superior de folhelhos cinzas. A espessura do membro Oatka Creek, baseada na análise de isópacas, varia na ordem de 270 pés (podendo atingir valores na ordem de 570 pés ou de 82 a 173 metros), nordeste da Pennsylvania, e 120 pés (36 metros), em Ohio; apresentando também valores na ordem de 30 pés ( 9 metros) na porção central de New York. Segundo Bruner \& Smosna (2011), essa divisão da formação Marcellus representa a complexidade de intercalações entre folhelhos ricos em matéria orgânica, os quais variam sua composição entre frações siltosas, carbonáticas e arenosas, além de variações no teor de matéria orgânica presente.

Fatores como a profundidade em que se encontra a formação e sua baixa permeabilidade classificaram Marcellus como um sistema petrolífero não convencional, cuja produção não era economicamente viável. Entretanto, o aumento no preço do gás natural desde 2008, associado a significativos avanços tecnológicos propiciaram a produção de hidrocarbonetos a partir dessa formação geológica por meio da implantação da técnica exploratória de faturamento hidráulico (Harper, 2008).

O folhelho Marcellus apresenta elevado conteúdo de matéria orgânica em sua composição, possuindo valores de teor de carbono orgânico total (COT) que atingem 20\%. Entretanto, a formação apresenta valores de COT predominantemente na ordem de 2 a $6 \%$; sendo o querogênio tipo II o predominante (Bruner \& Smosna, 2011). Em média, a formação é constituídas por folhelhos negros enriquecidos em matéria orgânica, com presença de calcita e pirita e conteúdo fossilífero esparso; intercalados à camadas de siltitos e argilitos. Análises realizadas nos folhelhos negros indicam valores na ordem de $35 \%$ de argilominerais, 10 a 20\% 
de quartzo/sílica, valores inferiores a $10 \%$ para feldspatos, 5 a $30 \%$ de muscovita e clorita, $25 \%$ de calcita, além de pirita e matéria orgânica em sua composição. Segundo Roen (1984 apud Bruner \& Smosna, 2011), a formação apresenta teores mais elevados de sílica (entre 40 e 60\%) na porção leste da bacia

A formação Marcellus abrange uma área geográfica de aproximadamente $140.000 \mathrm{~km}^{2}$ (75.000 $\left.\mathrm{mi}^{2}\right)$ de extensão e se encontra situado em profundidade média de $2 \mathrm{~km}$, ao longo da bacia sedimentar Appalachian, região nordeste dos Estados Unidos; pertencente aos estados de West Virgínia, Virgínia, Ontario, Pennsylvania, Ohio, Maryland, e New York. A formação apresenta, em média, 30 metros de espessura, atingindo valores em torno de 75 metros na porção nordeste do estado da Pennsylvania. Segundo Williams (2012), a formação apresenta um potencial estimado entre 295 a 2.700 TCF de gás natural, sendo as reservas recuperáveis calculadas em torno de $10 \%$ desse valor apresentado; o qual corresponde entre 1 a 10 anos de garantia de abastecimento de gás natural nos EUA, baseado no consumo atual (21 TCF por ano). Segundo Lee et.al.(2011), tanto a espessura quanto a profundidade do folhelho aumentam no sentido leste da bacia, sendo as porções do folhelho que apresentam principal concentração de gás natural estão situadas na região centro-norte da Pennsylvania e centro-sul de New York, com profundidades em torno de 60 metros, enquanto que porções menos profundas se apresentam no estado de Ohio, com valores inferiores a $0.9 \mathrm{~km}$ de profundidade. Apesar de maiores profundidades estarem geralmente associadas à maior concentração de gás natural, esta condição também implica no aumento do custo de produção. Ainda segundo os autores, esse considerável potencial da formação ainda está associado a diversos desafios tecnológicos e econômicos, os quais incluem a prospecção adequada e direcionada às porções de maior saturação em hidrocarbonetos, e a recuperação efetiva desta diante de propriedades de porosidade e permeabilidade bastante reduzidas.

De acordo com a classificação de Harper (2008), o folhelho Marcellus apresenta porosidade reduzida, na ordem de 0.5 a $5.0 \%$, apesar de valores na ordem de $9.0 \%$ terem sido registrados em West Virgínia. Devido à baixa conectividade entre poros na matriz deste folhelho, a recuperação de hidrocarbonetos a partir desta formação está intimamente associada à sua porosidade por fraturas, a qual varia entre 2.0 a $7.0 \%$.

A formação Marcellus apresenta dois conjuntos de fraturas (J1 e J2), J1 apresenta orientação preferencial leste-nordeste, paralela à zona de máximo stress horizontal, enquanto que J2 apresenta direção noroeste. De acordo com Engelder et.al.(2008a), com base na análise da orientação destas famílias de fraturas, a direção da perfuração direcionada foi determinada no sentido do conjunto de fraturas $\mathrm{J}$, devido estas serem mais desenvolvida ao longo do 
folhelho e por apresentarem menor espaçamento entre si, sendo assim de maior permeabilidade comparativamente à $\mathrm{J} 2$, propiciando maior recuperação de gás natural a partir de um único poço.

Segundo Engelder \& Lash (2008), o folhelho Marcellus apresenta saturação em água na ordem de 1,100 mg de $\mathrm{H} 20$ por $\mathrm{m}^{3}$ de gás natural, a qual deve ser removida para o transporte deste por gasodutos, os quais tipicamente possuem especificações para que conteúdo de água no gás seja restrito à $664-112 \mathrm{mg} \mathrm{H} 2 \mathrm{O} / \mathrm{m}^{3}$ de gás. Diversas estimativas referentes à concentração de gás natural em Marcellus estão presentes na bibliografia, sendo determinada por Haper (2008) em 30 TCF em reservas e cerca de 10\% deste valor em reservas recuperáveis. Comparativamente ao consumo médio anual de gás natural nos EUA, na ordem de 21 TCF, o campo de Marcellus é classificado com um "super gigante” por Lee et.al.(2011).

A formação Marcellus se encontra atualmente em produção de gás natural, recuperado a partir de poços verticais e horizontais, sendo estes acompanhados da técnica de faturamento hidráulico e cuja intersecção varia entre 600 e 1500 metros lateralmente. Segundo estimativas de Engelder et.al.(2008), poços horizontais têm produzido na formação cerca de 4 bilhões de pés cúbicos (BCF) de gás natural com base no cálculo de Recuperação Final Estimada (Estimated Ultimate Recovery - EUR), valores correspondentes ao triplo da produção de poços verticais, entretanto, apresentam um custo na ordem de 3,5 milhões de USD, comparados a 1 milhão de USD em poços verticais (Engelder \& Lash, 2008), Poços horizontais apresentam maior taxa de recuperação e, em Marcellus, são perfurados de maneira a intersectar, perpendicularmente, o maior número de fraturas possível para obter-se maior produtividade a partir do poço (padrão de faturamento em Marcellus: sentido leste-nordeste, então se perfura sentido norte-noroeste, intersectando de maneira perpendicular o conjunto de fraturas).

A aplicação da técnica de faturamento hidráulico resulta na geração de microfraturas ao longo da litologias, as quais permitem e propiciam a passagem do fluido para o interior do poço. Estas fraturas artificialmente geradas tendem a seguir o padrão do faturamento já existente na rocha. No caso do folhelho Marcellus, são geradas microfraturas transversais e paralelas ao conjunto de fraturas $\mathrm{J} 1$, estimulando a permeabilidade induzida e, consequentemente, a recuperação de hidrocarbonetos. No entanto, esse processo de faturamento induzido deve ser controlado a forma de prevenir extensões de fraturas e consequentes vazamentos; no caso de Marcellus, a formação se apresenta sobreposta a uma sequência carbonática denominada Onondaga, a qual auxilia na prevenção da continuidade dessas fraturas, atuando como uma rocha selante a esse sistema (Lee et.al.2008). Apesar do padrão de declínio exponencial na produção, a qual geralmente é reduzida a um quinto do valor inicialmente produzido ao longo 
de um período de cinco anos, Marcellus têm mantido valores consideráveis de produção; principalmente devido à implantação de técnicas de recuperação como a injeção de ácidos e/ou dióxido de carbono, que incentivam a recuperação de hidrocarbonetos sob custos relativamente baixos.

Dentre as principais consequências ambientais associadas à exploração desse recurso, destacam-se: a expansão do tráfego rodoviário na região, visto que o transporte de fluidos de equipamentos para a perfuração é essencialmente realizado por caminhões, os quais interferem na infraestrutura local, geram potencial contaminação de corpos hídricos na região e em emissão de poluentes provenientes desses veículos, além de indiretamente interferir na fauna local; consumo excessivo de água, o qual foi estimado entre 6.1 a 18.7 milhões de galões por dia (million gallons per day - MGD), valor correspondente a cerca de $1 \%$ do valor consumido diariamente no estado da Pennsylvania. Apesar de não ser alarmante, a explotação excessiva de água pode vir a ser prejudicial em períodos de seca na região. A principal questão ambiental associada à exploração de gás natural não convencional está relacionada ao descarte da água utilizada no processo, onde cerca de 30 a $70 \%$ da água utilizada no fraturamento retorna para a superfície, além da água retirada da formação geológica em recuperação. A água resultante desse processo apresenta sua composição alterada devido à adição de compostos químicos, além do consequente enriquecimento no total de partículas sólidas dissolvidas (total dissolved solids - TDS), na concentração de metais e de elementos radioativos provenientes de folhelhos ricos em matéria orgânica. A concentração de contaminante é controlada por meio de regulação, mediada pela Agência de Proteção Ambiental (Environmental Protection Agency - EPA), a qual define padrões e limites de concentração permitida por componente (Lee et.al.2011).

Diversas alternativas já estão presentes no mercado para esse descarte de água. Primeiramente, a água utilizada pode ser tratada conforme os padrões da EPA para água potável e tornar-se adequada ao consumo humano, no entanto, devido à necessidade de remoção de todos os tipos de contaminantes presentes, o processo se torna de custo elevado. Outra opção seria a injeção dessa água para o interior de reservatórios nos quais camadas confinantes atuariam como prevenção de contaminação de aquíferos a partir desse fluido (Soeder et.al.,2009). Por fim, a água pode receber tratamento para ser reutilizada no próprio processo de perfuração e fraturamento, o qual representa um tratamento consideravelmente menos intensivo e custoso do que o tratamento para torná-la potável; e têm sido bastante pesquisado e utilizado por diversas empresas operadoras no setor. Neste vaso, unidades adicionais de tratamento de água devem ser instaladas na região, visto que, geralmente, unidades municipais 
já presentam não são devidamente equipadas para o tratamento da água utilizada nesse processo.

Segundo Harper (2008), a produção de gás natural em Marcellus no estado da Pennsylvania desde 2009 a 2011, tem sido na média de 84 mil pés cúbicos de gás (thousand cubic feet - TCF) por dia, taxa de produção que pode ser mantida, segundo o autor, por cerca de 20 anos. No entanto, dados referentes à produção na porção oeste da Pennsylvania e leste de Ohio apresentam valores superiores à média indicada.

\subsubsection{BARNETT SHALE}

A formação geológica Barnett se apresenta inserida na bacia sedimentar norte-americana Fort Worth, atualmente situada na porção centro-norte do estado do Texas, abrangendo uma área total de aproximadamente 28.000 milhas $^{2}$ (aproximadamente $45.000 \mathrm{~km}^{2}$ ). A formação apresenta espessura e profundidade variadas, sendo presente em afloramentos na porção sudeste da bacia e com mergulho em subsuperfície no sentido Texas-Oklahoma, onde se apresenta em maior profundidade e mais espessa. Os limites geográficos da formação são representados pelo conjunto de falhas Ouachita, à leste, pelos arcos Muenster e Red River, ao norte, e pela plataforma Eastern e arco Concho, à oeste. A porção geradora de gás natural não convencional (shale gas) corresponde a cerca de um terço da extensão total da formação (aproximadamente 9.000 milhas $^{2}$ ou $23.000 \mathrm{~km}^{2}$ ), sendo que a produção desse recurso se concentra ao norte da bacia, onde a formação Barnett possui maior espessura (Montgomery et al., 2005).

A bacia de Fort Worth vem sido explorada desde 1900 para a produção convencional de hidrocarbonetos. A partir de 1998, o reconhecimento de formações geológicas correspondentes a continuas acumulações de gás natural não-associado, atribuídas ao folhelho Barnett, promoveram a exploração de gás natural não convencional a partir dessa formação (Loucks \& Ruppel, 2007). A bacia data do Paleozóico superior e sua formação é associada à orogenia Ouachita, resultante da convergência entre os megacontinentes Laurussia e Gondwana. A bacia é caracterizada como de antepaís e estava situada na porção sul, nos limites de Laurussia, conforme representado na figura 32. Atualmente, a bacia é classificada como de baixa profundidade, assimétrica, e com eixo estrutural no sentido norte-sul, paralelo ao lineamento Ouachita. A bacia é estruturalmente mais profunda em sua porção nordeste e suavemente mais rasa nas direções oeste e sudoeste, onde são expostas rochas pré-cambrianas e paleozóicas (Figura 33) (Loucks \& Ruppel, 2007). 


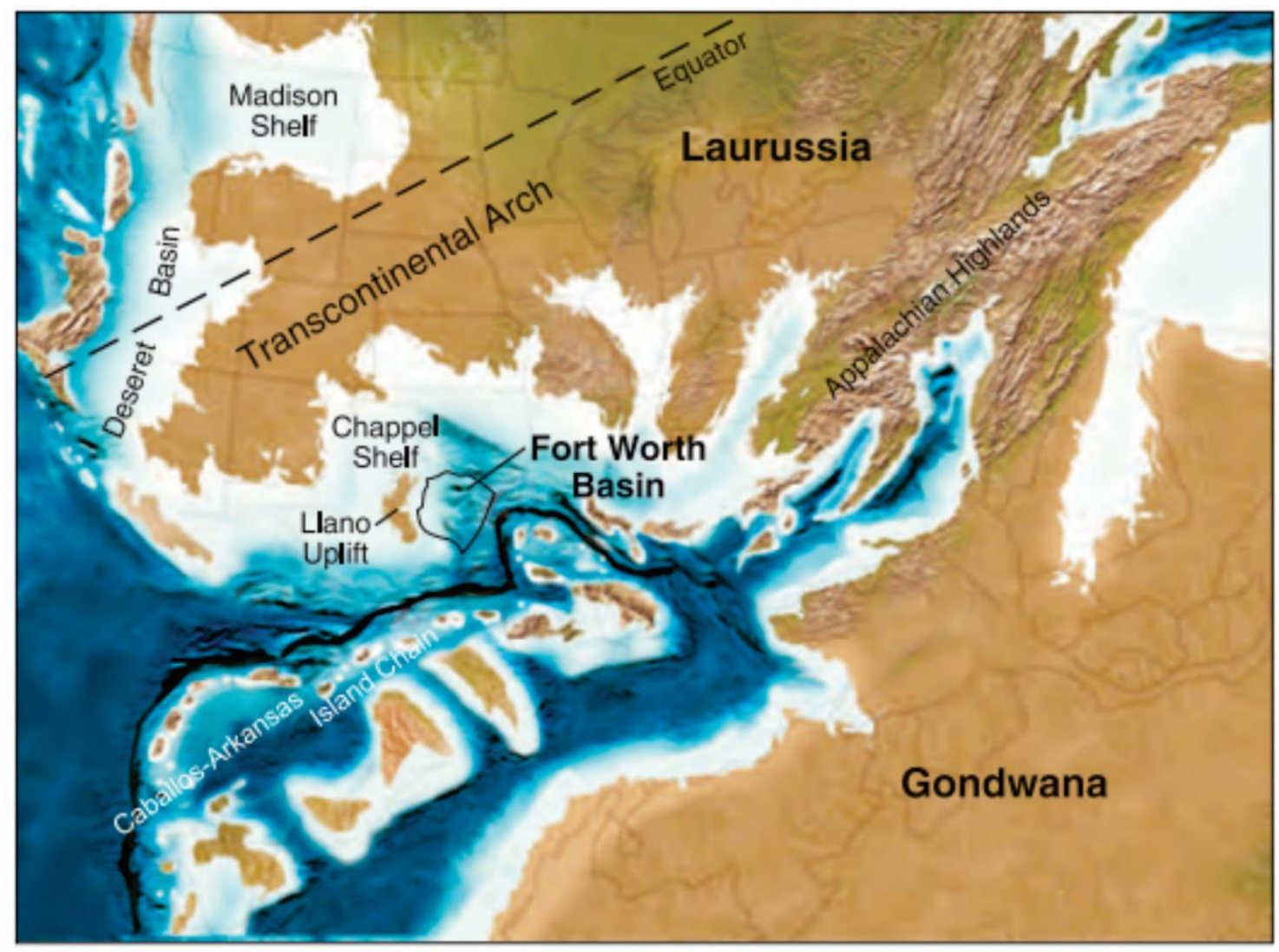

Figura 32 - Representação da paleogeografia regional do Mississipiano superior (325 Ma), indicando a localização e o contexto geológico formacional da bacia sedimentar Fort Worth. Loucks \& Ruppel (2007).

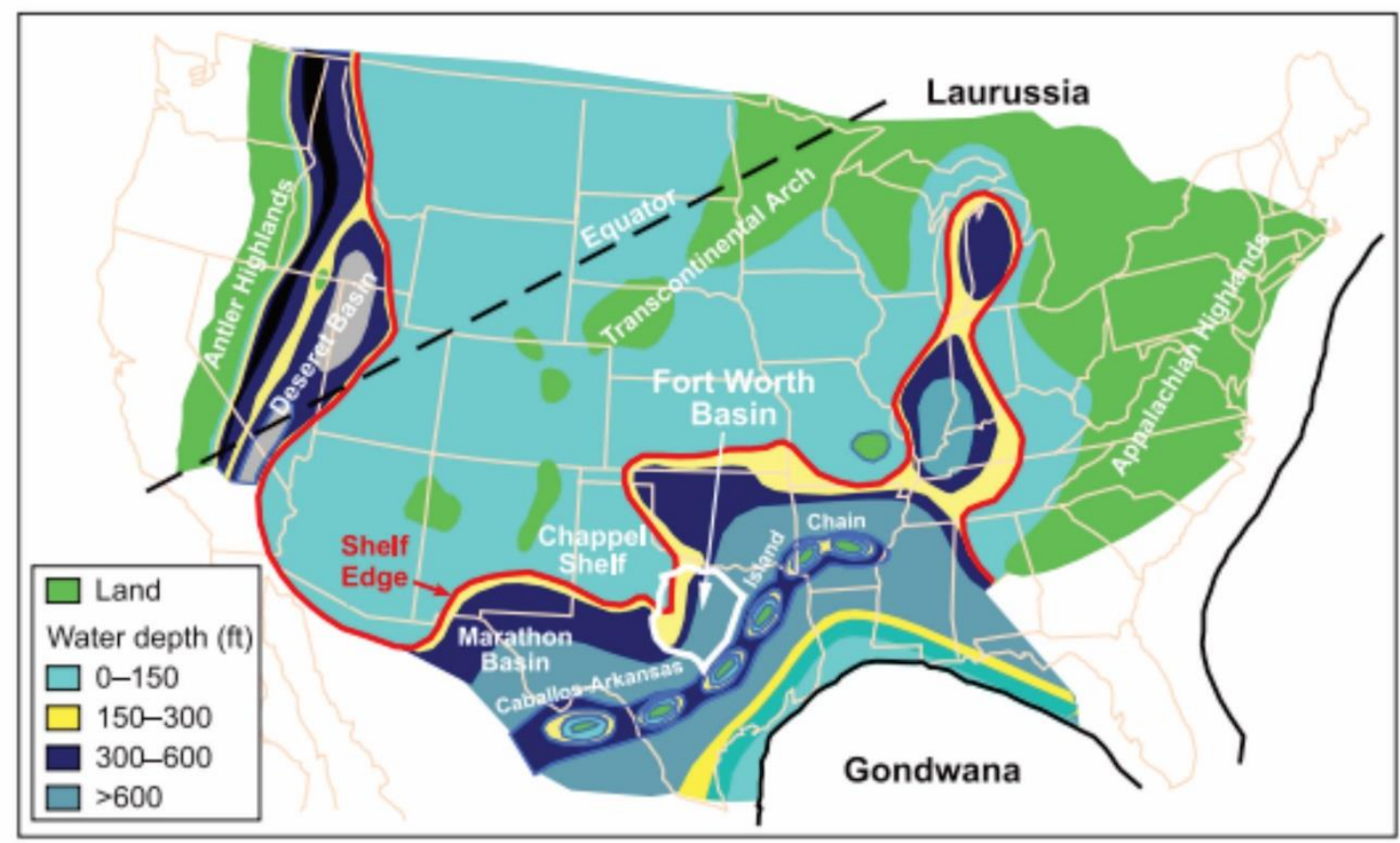

Figura 33 - Mapa paleogeográfico dos Estados Unidos representando as variações de profundidade presentes na bacia Fort Worth e arredores, indicando zonas mais favoráveis à ocorrência de gás natural não convencional (maiores profundidades). Fonte: Loucks \& Ruppel (2007). 
Com base na estratigrafia da bacia, pode-se afirmar que a formação Barnett corresponde ao conjunto de folhelhos laminados, de composição silicosa e carbonática, e carbonatos. A composição predominante é representada por folhelhos negros ricos em matéria orgânica, fossilíferos, e carbonatos densos, de coloração escura, e também fossilíferos, ambos datados do Mississipiano superior (Lancaster et al., 1993). Na porção nordeste da bacia Fort Worth, a formação Barnett é informalmente dividida em dois membros: superior e inferior; divisão baseada no aumento do teor de carbonatos (maior no membro superior). No entanto, ambos os membros se apresenta intercalados à camadas carbonáticas (calcitas e dolomitas).

Segundo Bruner \& Smosna (2011), o folhelho Barnett apresenta profundidade bastante variável, a partir de 50 pés, sendo a profundidade máxima em torno de 10.000 pés (aproximadamente entre 15 e 3000 metros). Sua litologia é basicamente constituída de calcários e folhelhos negros, os quais variam composicionalmente entre silicosos e carbonáticos. Análises de raios-gama nos folhelhos indicam valores que variam de 150 a $200^{\circ}$ API e densidades de amostras em torno de 2,40 e 2,50 g/ $\mathrm{cm}^{3}$. A porosidade da formação se aproxima de $6 \%$ e a saturação em água, entre 20 e $30 \%$. A saturação em gás foi medida entre 70 e $80 \%$, sendo este predominantemente armazenado no interstício dos poros e em microfraturas. A pressão na formação varia entre 3000 e 4000 psi. Os valores de carbono orgânico total (COT), variam entre 2 e $12 \%$ ao longo da formação, sendo os valores mais elevados correspondentes ao membro inferior da formação, com matéria orgânica predominante do tipo II, mas tipo III também presente. Valores de reflectância de vitrinita (Ro) em torno de 1,2\%.

A formação Barnett é delimitada na bacia Fort Worth por zonas orogênicas: por Ouachita Thrust à leste, pelos arcos Muesnter e Red River ao norte, e plataforma Eastern e Arco Concho à oeste (Montgomery et.al. 2005). A atividade tectônica atuante na bacia resultou na presença de diversas desconformidades em sua sessão estratigráfica (Figura 34). Dentre os campos produtores de shale gas na formação de Barnett (shale plays), o principal corresponde ao campo Newark East, situado nos condados de Denton, Wise e Tarrant. Esse campo produtor abrange uma área em torno de $1300 \mathrm{~km}^{2}$, e possui cerca de 2400 poços produtores e potencial estimado em 2,7 trilhões de pés cúbicos de gás (Tcf) em reservas provadas (Durham, 2005; Montgomery e et al., 2005). 

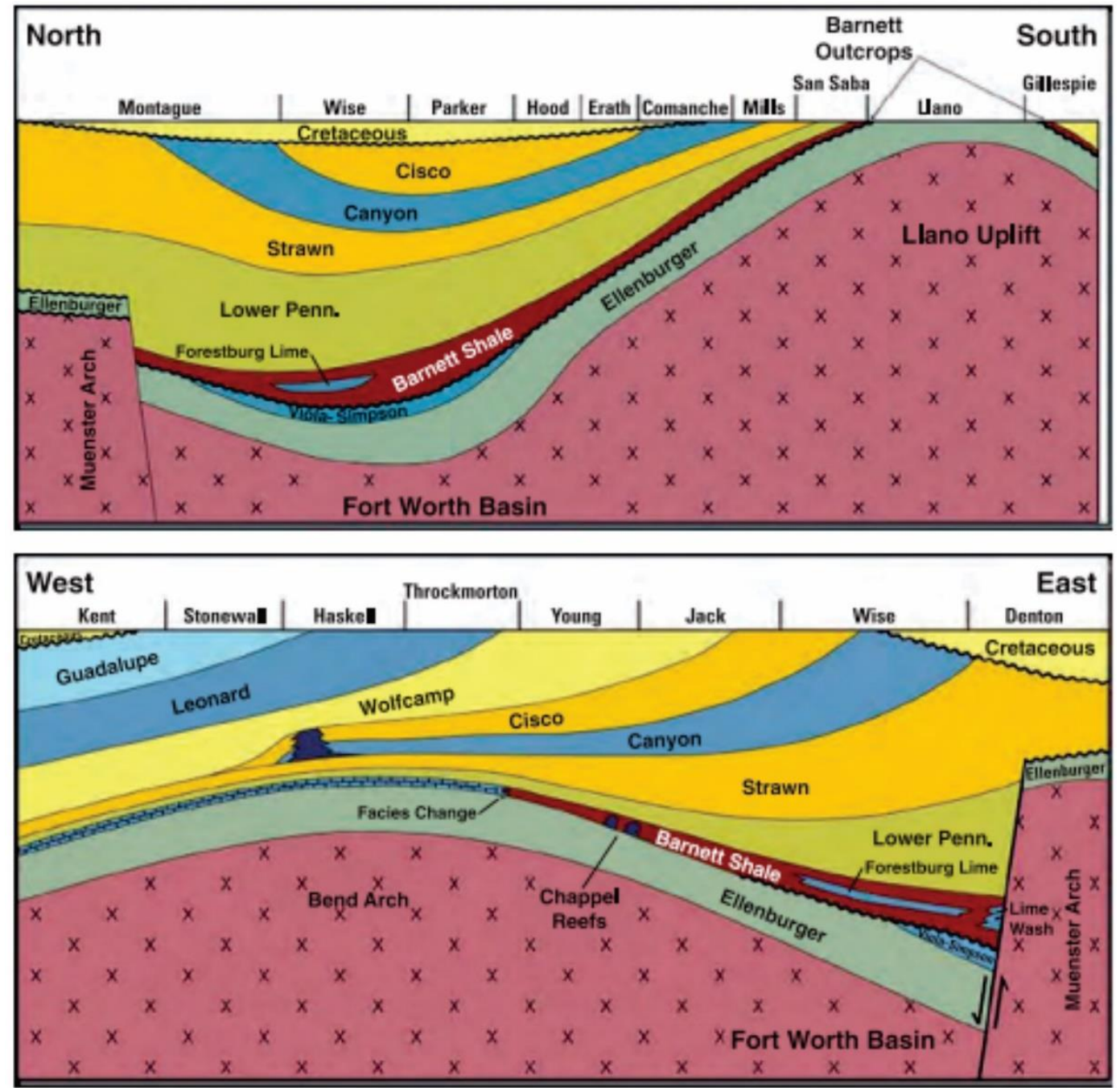

Figura 34 - Sessões estratigráficas norte-sul e leste-oeste da bacia sedimentar Fort Worth, representando o posicionamento estrutural da formação Barnett ao longo da bacia. Bruner \& Smosna (2011).

Fonte:

Com base em análises lito-estratigráficas de Loucks \& Ruppel (2007), a mineralogia da formação Barnett é constituída por, aproximadamente, 35 a 50\% de sílica/quartzo, menos de $35 \%$ de argilominerais. Análises detalhadas indicam: 45\% de quartzo, 27\% de ilita e esmectitia, $8 \%$ de calcita e dolomita, $7 \%$ de feldspatos, $5 \%$ de matéria orgânica, $5 \%$ de pirita, e 3\% de pirita e elementos traço (Bowker, 2002 apud Bruner \& Smosna, 2011).

O ambiente deposicional de Barnett foi determinado por Loucks \& Ruppel (2007) como de plataforma marinha, com presença de condições anaeróbicas (deposição do folhelho negro e matéria orgânica e pirita) e aeróbicas (carbonatos). A produção de hidrocarbonetos a partir dessa formação é predominantemente de gás natural termogênico (cerca de 90\%). Dióxido de carbono $\left(\mathrm{CO}_{2}\right)$ equivale a aproximadamente $2 \%$ do volume total de gás produzido; nitrogênio e enxofre ocorrem em frações traço. 


\subsubsection{EAGLE FORD SHALE}

Eagle Ford corresponde a uma formação geológica geradora de hidrocarbonetos datada do Cretáceo Superior e associada ao ambiente deposicional de plataforma marinha-continental. Sua composição é predominantemente representada por folhelhos carbonosos ricos em matéria orgânica (40-90\%), argilominerais (15-30\%), e quartzo/sílica (15-20\%). Seu conteúdo de carbono orgânico total (COT) varia entre 2 a $12 \%$, maturidade termal $\left(\mathrm{R}_{\mathrm{o}}\right)$ entre 0.45 a $1.4 \%$, API entre 28 e $62^{\circ}$, porosidade entre 8 e $12 \%$, e gradiente de pressão (psi/ft) entre 0.5 e 0.8 , e a espessura da porção geradora varia entre 45 e 450 pés (12 a 137 metros). A profundidade em que se encontra a formação é bastante variável, sendo geralmente superior a 4.000 pés e podendo atingir até 14.000 pés (cerca de 1.200 a 4.200 metros) (EIA, 2014).

De acordo com Za Za Energy (2013 apud EIA, 2014), a formação Eagle Ford divide-se em dois diferentes membros: uma unidade superior, caracterizada por intercalações de rochas carbonáticas e folhelhos cujas deposições estão associadas à regimes transgressivos (intervalos de mar baixo); e uma unidade inferior, predominantemente constituída por folhelhos negros depositados em regime transgressivo (intervalos de mar alto). Eagle Ford é sobreposta aos calcáreos da formação Buda e sotoposta à Austin Chalk. O membro superior apresenta maior razão carbonato/argila em relação ao membro inferior (Parra et al., 2013).

A formação geológica Eagle Ford abrange uma área de aproximadamente 20.000 milhas quadradas $\left(52.000 \mathrm{~km}^{2}\right)$ nas porções sul e sudeste do Texas. A formação é originalmente conhecida como rocha geradora de hidrocarbonetos no sistema petrolífero de Austin Chalk, produtor de óleo e gás natural, e mergulha em direção ao Golfo do México. A formação é essencialmente constituída por folhelhos negros e carbonatos, sendo o conteúdo carbonático predominante: corresponde a cerca de $70 \%$ da formação; composição a qual, devido ao elevado conteúdo carbonático e baixo teor de argilas, caracteriza um comportamento mais frágil e rúptil à unidade, favorecendo a implantação da técnica de faturamento hidráulico (Matsutsuyu, 2011).

A formação geológica Eagle Ford está inserida na bacia sedimentar de Maverick, atualmente situada no estado do Texas, e é a formação mais espessa da bacia. A extensão da formações Eagle Ford e variações em sua espessura, profundidade e estratigrafia ao longo da bacia são atribuídas, principalmente, à aspectos tectônicos regionais, os quais envolvem a bacia Maverick, o arco San Marcos, a margem das plataformas continentais Stuart City e Sligo, e a bacia East Texas, representados na figura 35 (Hentz \& Ruppel, 2011). 


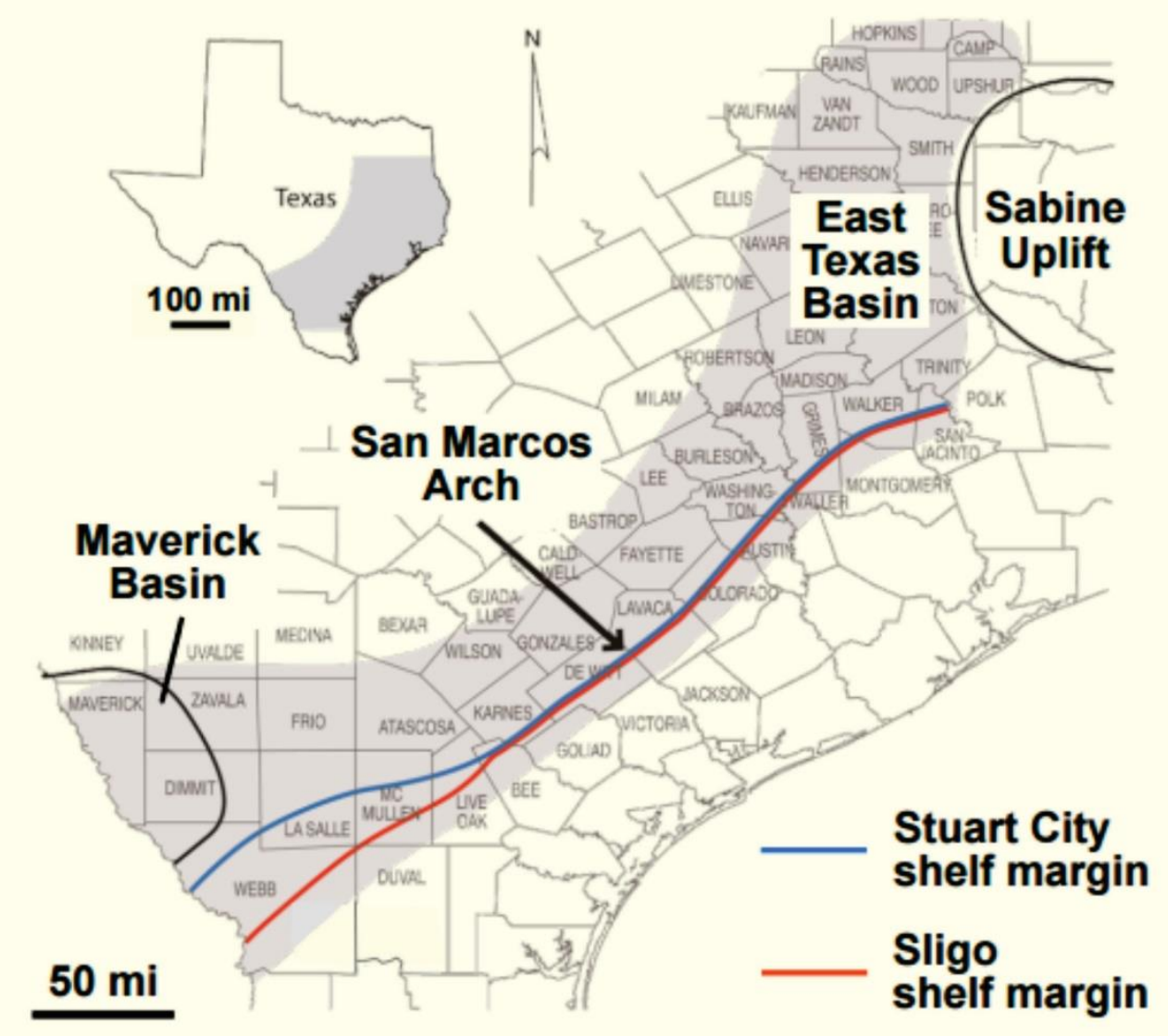

Figura 35 - Mapa representativo da localização e das principais feições tectônico-estruturais relacionadas à formação Eagle Ford, porção sul do estado do Texas. EIA (2014).

Do período de 2008 a 2012, Eagle Ford se tornou um dos campos de shale gas mais ativamente explorados nos Estados Unidos; com poços petrolíferos verticais e horizontais que chegam a produzir 1000 barris de petróleo por dia e mais de 200 rigs exploratórios. A exploração e produção de Eagle Ford se intensificou a partir de 2008, inspirada na produtividade e retorno econômico a partir da formação Barnett, bacia Fort Worth, também no Texas (EIA, 2014).

\subsection{Análise Comparativa}

Muitos programas de exploração e produção de hidrocarbonetos são baseados em analogias com campos petrolíferos comprovadamente produtores. Como exemplo, o campo de Barnett, bacia sedimentar Fort Worth, descoberto em 1981, teve sua exploração encorajada devido comparações com o folhelho devoniano da bacia Appalachian (Marcellus), comprovadamente gerador (Steward, 2007 apud Bruner \& Smosna, 2011). Nesse contexto, estudos de revisão bibliográfica e compilação de informações referentes à caracterização geológica desses campos 
produtores de shale gas, principalmente de parâmetros comparativos como espessura do reservatório, teor de carbono orgânico, maturidade termal, volume de gás, e fração de gás adsorvido, são essenciais na determinação de condições ótimas para ocorrência de gás natural não convencional em diferentes localidades. Nesse contexto, o presente trabalho de pesquisa propõe a análise comparativa entre os principais campos produtores de gás natural não convencional dos Estados Unidos (maior produtor e pioneiro na produção desse recurso), a fim de, por meio de analogia, se determinar o potencial para ocorrência desse recurso no Brasil; mais especificamente nas formações Irati e Ponta Grossa da Bacia do Paraná.

Segundos aspectos geológicos, os campos produtores de Marcellus, Barnett e Eagle Ford são relativamente semelhantes: as formações estão inseridas em um contexto de acumulação em bacias sedimentares de antepaís, ao longo de margens convergentes de placas tectônicas delimitadas por limites estruturais de falhas e fraturas consequentes de orogenias, as quais contribuíram para o aumento da espessura dos pacotes sedimentares.

Suas composições litoestratigráficas também coincidem: folhelhos negros ricos em matéria orgânica e carbonatos; além de apresentarem divisão em membros, baseada em variações na predominância destas litologias e na proporção argila/sílica. Segundo aspectos geoquímicos, a formação Eagle Ford apresenta variações significativas, enquanto as formações Barnett e Marcellus possuem maior similaridade: apesar de pequenas diferenças de composições geoquímicas, ambas as formações geralmente apresentam valores similares de análise de raiosgama: na ordem de 150 a 200 API, e se apresentam em profundidades entre 500 a 1000 pés (150 a 300 metros). Em termos de características básicas de reservatórios, as formações são bastante similares, segundo análises de Bruner \& Smosna, (2011):

- Porosidade: aproximadamente 6\%;

- Saturação em água: entre 20 e 30\%, contato com argilominerais, sem água livre;

- Saturação em gás: entre 70 a $80 \%$, presente em poros intersticiais, microfraturas, e adsorvido à matéria orgânica sólida e querogênio;

- Gás adsorvido: valores mínimos de 20 a 25\% e máximos de 40 a 60\%;

- Pressão interna do reservatório: estágios predominantes de pressão normal à sobrepressão (0,46 a 0,52 psi/ft); apesar de Marcellus apresentar porções der baixa pressão $(0,10$ a $0,35 \mathrm{psi} / \mathrm{ft})$;

- Pressão formacional: de 3,000 a 4,000 psi;

- Profundidade de perfuração: 4.000 a $8.500 \mathrm{ft}$ em Barnett (1.200 a $2.500 \mathrm{~m}$ ) e 2.000 a $10.000 \mathrm{ft}$ em Marcellus (600 a 3.000); 
Já a formação Eagle Ford, apresenta valores menores de raios-gama (entre 28 e $\left.62^{\circ} \mathrm{API}\right)$, e maiores de porosidade (entre 8 e 12\%) e de gradiente de pressão (entre 0.5 e 0.8 psi/ft, e média de $0.65 \mathrm{psi} / \mathrm{ft}$ ). Além de a perfuração atingir profundidades na ordem de $11.500 \mathrm{ft}$ (cerca de $3.500 \mathrm{~m})$ (EIA, 2014).

Em termos de geração de hidrocarbonetos, as formações se diferem: Eagle Ford apresenta um potencial estimado de gás natural em 278 trilhões de pés cúbicos (Tcf), enquanto que Barnett apresenta cerca de 390 Tcf e Marcellus de 500 Tcf. O conteúdo de carbono orgânico total (COT\%), nestas formações, varia entre 2 e $12 \%$ (predominantemente de 2 a $6 \%$ em Barnett, 2 a 10\% em Marcellus, e 2 a 12\% em Eagle Ford). As formações descritas são essencialmente constituídas de querogênio tipo II e III, sendo que os campos de Barnett e Eagle Ford apresentam maior fração de querogênio tipo II (mais favorável à geração de gás natural) do que Marcellus. A maturidade termal das bacias sedimentares em que estas formações estão inseridas é atribuída ao soterramento pós deposicional, o qual é relativamente uniforme ao longo das bacias e, consequentemente, mais homogênea nas formações; apresentando apenas variações locais nas proximidades de zonas de falhas e fraturas e de influência hidrotermal. O valores de reflectância de vitrinita $\left(\mathrm{R}_{\mathrm{o}}\right)$ são da ordem de 1.4 em Eagle Ford, 1.2 em Barnett e 1.6 em Marcellus; diferença relacionada à velocidade do aquecimento e taxa de maturação (maior em Marcellus devido condições paleoambientais) (Bruner \& Smosna, 2011).

Com base nos dados apresentados por Bruner \& Smosna (2011) e Norton Rose Fulbright (2013), foi desenvolvida a seguinte tabela descritiva-comparativa, a qual sumariza os principais parâmetros essenciais à ocorrência de gás natural não convencional (shale gas) e compara esses parâmetros dentre os principais campos produtores desse recurso até 2014: Marcellus, Barnett e Eagle Ford (Tabela 8). 
Tabela 8 - Análise comparativa dos campos Marcellus, Barnett e Eagle Ford, comprovadamente geradores e produtores de gás natural não convencional.

\begin{tabular}{|c|c|c|c|}
\hline Parâmetros Comparativos & Marcellus & Barnett & Eagle Ford \\
\hline Idade Geológica & Devoniano médio & Mississipiano superior & Cretáceo superior \\
\hline Litologia & $\begin{array}{l}\text { Folhelhos negros carbonosos, altamente } \\
\text { radioativos, com concreções } \\
\text { carbonáticas; Folhelhos enriquecidos em } \\
\text { sílica e matéria orgânica. }\end{array}$ & $\begin{array}{l}\text { Folhelhos negros densos, silicosos, } \\
\text { petrolíferos, fossilíferos e ricos em matéria } \\
\text { orgânica; Carbonatos cristalinos, petrolíferos } \\
\text { e fossilíferos; Folhelhos negros altamente } \\
\text { enriquecidos em sílica (mais rúpteis). }\end{array}$ & $\begin{array}{l}\text { Folhelhos carbonosos ricos em matéria } \\
\text { orgânica; carbonatos petrolíferos e } \\
\text { fossilíferos também enriquecidos em } \\
\text { matéria orgânica. }\end{array}$ \\
\hline $\begin{array}{l}\text { Composição Mineralógica } \\
\text { Predominante ( \% volume) }\end{array}$ & $\begin{array}{l}\text { Sílica }(10-20 \%) ; \text { argilominerais }(35 \%) \text {; } \\
\text { carbonatos }(50 \%)\end{array}$ & $\begin{array}{l}\text { Sílica }(35-50 \%) ; \text { argilominerais } \quad(<35 \%) \text {; } \\
\text { carbonatos }(20 \%)\end{array}$ & $\begin{array}{l}\text { Sílica }(15-20 \%) ; \text { argilominerais } \\
30 \%) \text {; carbonatos }(40-90 \%)\end{array}$ \\
\hline Mineralogia (\% volume) & $\begin{array}{l}27-31 \% \text { quartzo, } 9-34 \% \text { ilita, } 1-7 \% \\
\text { complexo de argilominerais, } 0-4 \% \\
\text { clorita, } 3-48 \% \text { calcita, } 0-10 \% \text { dolomita, } 0- \\
4 \% \text { feldspato sódico, } 5-13 \% \text { pirita, e } 0- \\
6 \% \text { gipso. }\end{array}$ & $\begin{array}{l}30-50 \% \text { quartzo, } 27 \% \text { ilita e traços de } \\
\text { esmectita, } 8-19 \% \text { calcita e dolomita, } 7 \% \\
\text { feldspato, } 5 \% \text { matéria orgânica, } 5 \% \text { pirita, } 3 \% \\
\text { siderita, e traços de material fosfático e cobre. }\end{array}$ & $\begin{array}{l}15-20 \% \text { quartzo, } 15-30 \% \text { argilominerais, } \\
40-90 \% \text { calcita e dolomita + matéria } \\
\text { orgânica + pirita. }\end{array}$ \\
\hline Área $\left(\mathrm{km}^{2}\right)$ & 60.000 & 13.000 & 12.140 \\
\hline Espessura (m) & 15-200 (tipicamente 15-80) & 15-300 (tipicamente 45-180). & 15-150 (tipicamente 70) \\
\hline Profundidade (m) & $600-3.000$ & $1.200-2.500$ & $1.200-4.000$ \\
\hline $\begin{array}{l}\text { Tipo de Querogênio } \\
\text { Predominate }\end{array}$ & II e III (tipo II predominante) & II (apenas traços de tipo III) & II e III \\
\hline $\operatorname{Ro}(\%)$ & 1.60 (máximo de 3.5) & 1.2 (máximo de 1.9) & 1.4 \\
\hline COT (\%) & $1-10$ & $2-6$ & $2-12$ \\
\hline Tmáx $\left({ }^{\circ} \mathbf{C}\right)$ & 470 & 465 & 335 \\
\hline Maturidade Termal & $\begin{array}{l}\text { Rochas } \\
\text { supermaturas } \text { (gás termogênico). } \\
\text { Associada à profundidade de } \\
\text { soterramento e fluxo térmico em zonas de } \\
\text { falhas. }\end{array}$ & $\begin{array}{l}\text { Rochas que variam de imaturas à } \\
\text { supermaturas. Associada à profundidade de } \\
\text { soterramento e atividade hidrotermal ao longo } \\
\text { de zonas de falhas e fraturas. }\end{array}$ & $\begin{array}{l}\text { Rochas que variam de imaturas à } \\
\text { supermaturas. Associada à profundidade } \\
\text { de soterramento e atividade hidrotermal } \\
\text { ao longo de zonas de falhas e fraturas. }\end{array}$ \\
\hline $\begin{array}{l}\text { Classificação da Bacia } \\
\text { Sedimentar }\end{array}$ & $\begin{array}{l}\text { Antepaís, assimétrica, delimitada por } \\
\text { cinturões orogênicos, arcos estruturais e } \\
\text { soerguimento pré-cambriano. }\end{array}$ & $\begin{array}{l}\text { Antepaís, assimétrica, delimitada por } \\
\text { cinturões orogênicos proeminentes, arcos } \\
\text { estruturais e soerguimento pré-cambriano. }\end{array}$ & $\begin{array}{l}\text { Antepaís, assimétrica, delimitada por } \\
\text { cinturões orogênicos. }\end{array}$ \\
\hline
\end{tabular}


Paleoambiente Deposicional

\section{Características}

Reservatório (\%)
Bacia sedimentar de águas profundas, Bacia sedimentar de águas profundas, baixa baixa circulação, coluna d'água circulação, coluna d'água estratificada, estratificada, ambiente redutor na base, ambiente redutor na base, presença de matéria presença de matéria orgânica algácea- orgânica algácea-planctônica, profundidade planctônica, profundidade da lâmina da lâmina d'água em torno de 150 a $200 \mathrm{~m}$. d'água em torno de 100 a $300 \mathrm{~m}$.

do $\varphi=6, \mathrm{k}=$ micro-nanodarcies, $\mathrm{Sw}=30$ (sem água livre), $\mathrm{Sg}=70$ (gás alocado em poros intersticiais e microfraturas, e adsorvido à matéria orgânica e querogênio: 20-80\% ); pressão interna do reservatório: de $0.51 \mathrm{psi} / \mathrm{ft}$ (sobrepressão) a $0.10-0.35 \mathrm{psi} / \mathrm{ft}$ (baixa pressão)
Bacia sedimentar em plataforma marinho-continental, baixa circulação, coluna d'água estratificada, ambiente redutor na base, presença de matéria orgânica algácea-planctônica, profundidade da lâmina d'água em torno de $100 \mathrm{~m}$.

$\varphi=3-6, \mathrm{k}=$ micro-nanodarcies, $\mathrm{Sw}=25$ (sem água livre), $\mathrm{Sg}=75$ (gás alocado em poros intersticiais e microfraturas, e adsorvido à matéria orgânica e querogênio: 20-60\%); estágio de sobrepressão: $0.52 \mathrm{psi} / \mathrm{ft}$

$\varphi=8, \mathrm{k}=$ micro-nanodarcies, $\mathrm{Sw}=20$ (sem água livre), $\mathrm{Sg}=75$ (gás alocado em poros intersticiais e microfraturas, e adsorvido à matéria orgânica e querogênio: $20-80 \%$ )pressão interna do reservatório: de $0.5-0.8 \mathrm{psi} / \mathrm{ft}$, média de $0.65 \mathrm{psi} / \mathrm{ft}$ (sobrepressão) 


\section{GEOLOGIA REGIONAL DA BACIA DO PARANÁ}

\subsection{Aspectos Gerais}

A Bacia do Paraná corresponde a uma vasta região de sedimentação na América do Sul, sendo caracterizada como uma bacia intracratônica. Situada na porção centro-oriental da Plataforma Sul-Americana a bacia compreende porções territoriais no Brasil meridional, Paraguai oriental, nordeste da Argentina e norte do Uruguai (Figura 36), que totalizam uma área de aproximadamente 1,4 milhão de quilômetros quadrados: 1,1 milhões km² no Brasil, 100 mil km² no Paraguai, Argentina e Uruguai. Incluem-se na porção brasileira da bacia, em proporções significativas, os estados de São Paulo, Paraná, Santa Catarina e Rio Grande do Sul, e em proporções menores, os estados de Mato Grosso, Mato Grosso do Sul, Goiás e sudoeste de Minas Gerais (Figura 37) (Zalán, et al. 1988, 1990a).

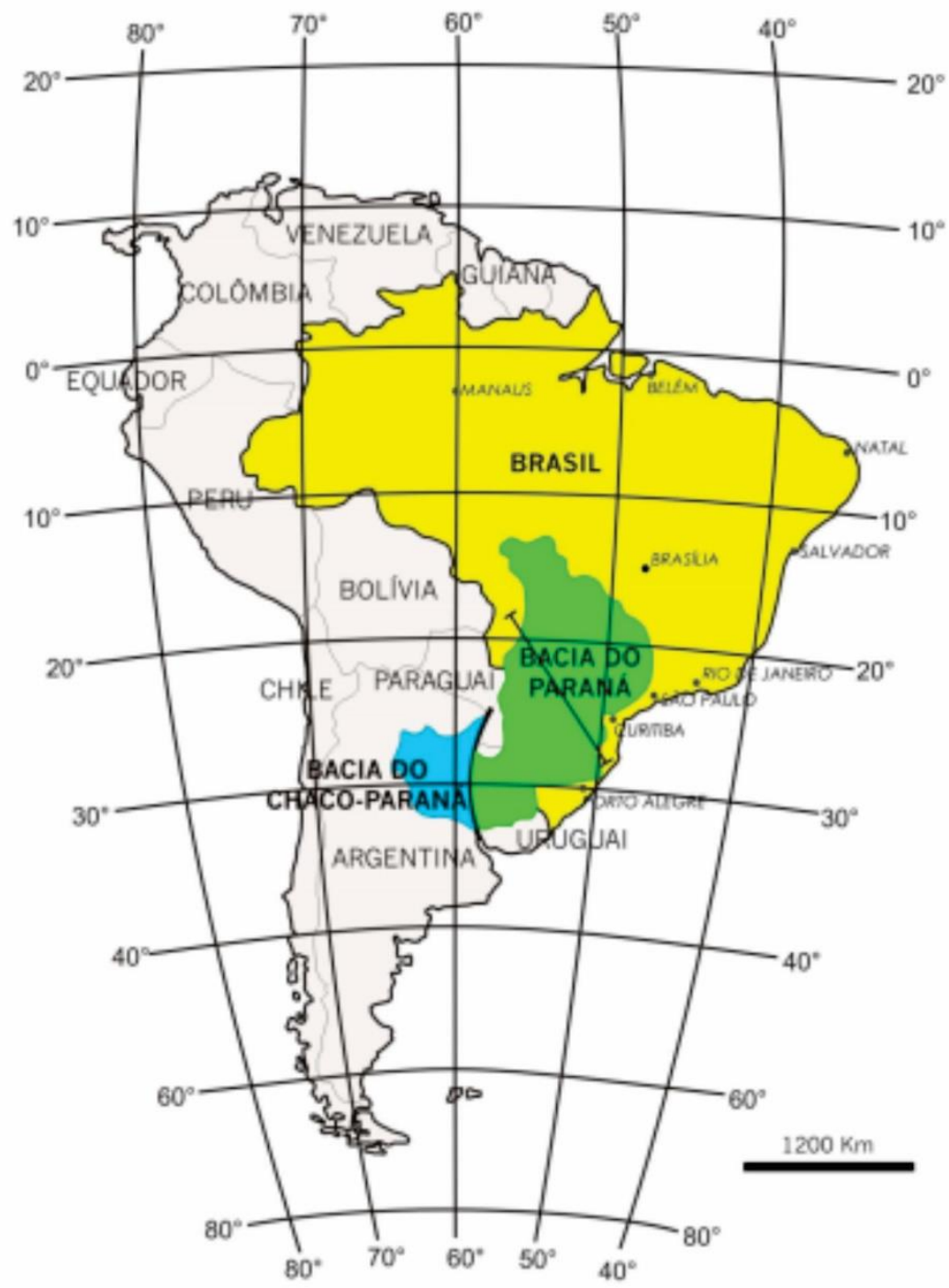

Figura 36 - Mapa de localização da Bacia do Paraná na Plataforma Sul-Americana. Zalán et al. (1990). 


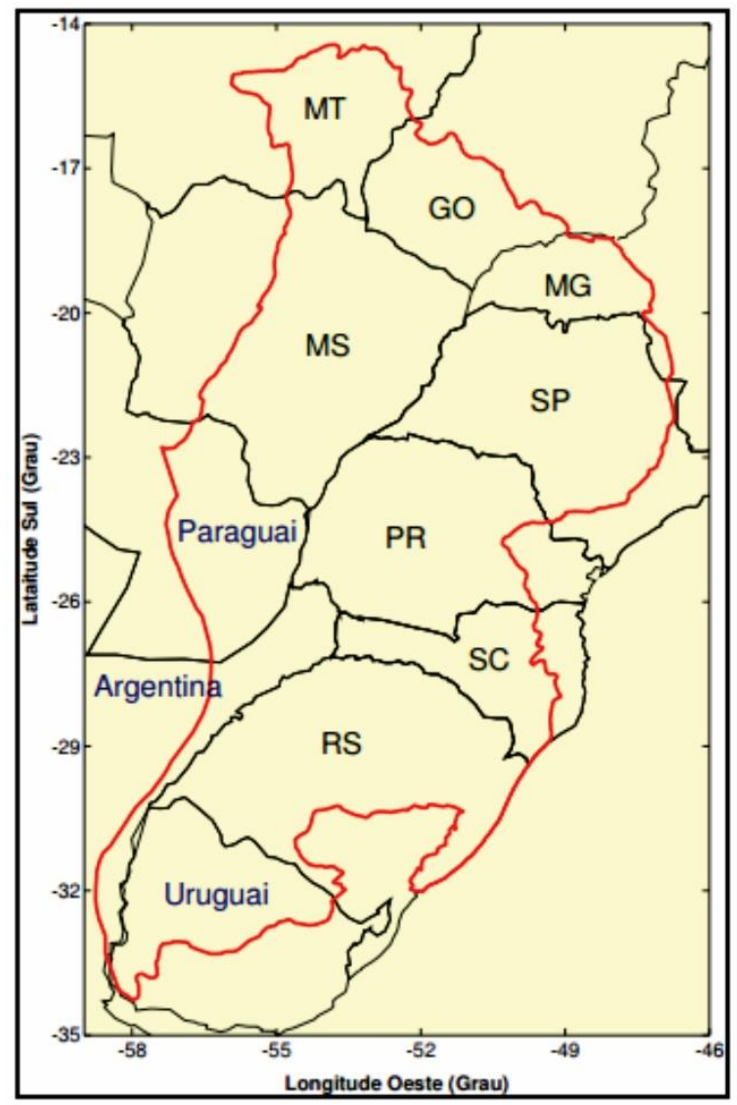

Figura 37 - Mapa de localização da Bacia do Paraná (contorno em vermelho) representando seu limites nos estados brasileiros (MT, MS, GO, MG, SP, PR, SC, RS) e países vizinhos (Paraguai, Argentina e Uruguai). Fonte: Lima Gomes (2009).

Inserida no contexto geológico paleocontinental de Gondwana, a evolução geológica Bacia do Paraná é atribuída aos períodos Paleozóico e Mesozóico, apresentado um registro estratigráfico magmático e sedimentar de espessura total máxima em torno de 7 mil metros, cujo posicionamento espacial coincide geograficamente com o depocentro estrutural da sinéclise com a calha do rio Paraná, a partir do qual, segundo Maack (1947), a bacia foi nomeada. Já o posicionamento temporal varia entre Neo-Ordoviciano e Neocretáceo (Milani, 1997). Sua evolução tectono-estratigráfica engloba o conjunto e sucessão de processos que incluem distensão continental, subsidência térmica e ajustes isostáticos (Milani, 2004).

O contorno da bacia configura um limite erosivo ao longo de grande parte de seu perímetro, atingindo aproximadamente 5.500 quilômetros de diâmetro. Morfologicamente, a Bacia do Paraná representa predominantemente eventos pós-paleozóicos do continente sul-americano. À leste, o flanco da bacia, esculpido pela erosão decorrente do soerguimento marginal do rifte sulatlântico, expõe significativamente o embasamento cristalino; enquanto que, à oeste, a bacia é delimitada pelo Arco de Assunção, a qual decorre da sobrecarga litosférica devido o cinturão andino e que segrega a Bacia do Paraná de áreas anteriormente à esta pertencentes, como o chaco paraguaio-boliviano. O nordeste da bacia evidencia um limite original, representado por 
uma paleoborda deposicional. A bacia se prolonga até os territórios no Uruguai e Paraguai, à sudoeste (Milani, 2004).

Seis unidades estratigráficas de ampla escala, ou supersequências, foram identificadas por Milani (1997) na bacia, são estas: Rio Ivaí (Ordoviciano-Siluriano), Paraná (Devoniano), Gondwana I (Carbonífero-Eotriássico), Gondwana II (Meso a Neotriássico), Gondwana III (Neojurássico-Eocretáceo) e Bauru (Neocretáceo). Segundo o autor, as três primeiras supersequências representam ciclos transgressivo-regressivos relacionados à oscilação do nível relativo do mar característico do Paleozóico; e os demais correspondem a pacotes sedimentares continentais mesozoicos associados a intrusões ígneas (Figura 38). 


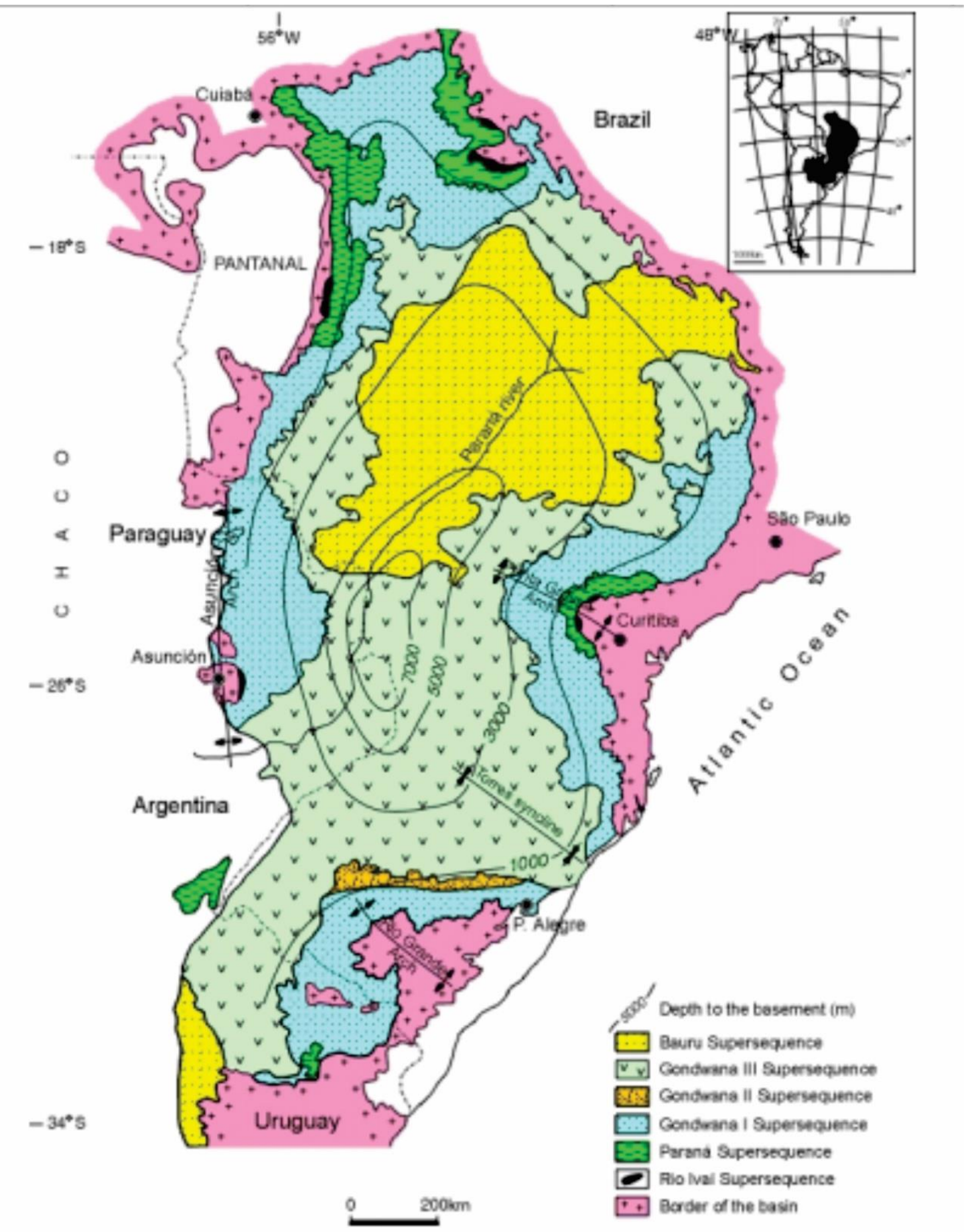

Figura 38 - Mapa Geológico simplificado da Bacia do Paraná; com contorno estrutural (profundidade) do embasamento cristalino.

Fonte: Milani (2004).

A temática da geologia da Bacia do Paraná é historicamente estudada e compreendendo diversas centenas de trabalhos publicados que abordam os diferentes aspectos desta questão, constituindo um dos principais temas presentes na bibliografia geocientífica brasileira (Milani et al. 2007). Nesse contexto histórico, destacam-se os trabalhos de White (1908), considerado o "marco zero" da caraterização estratigráfica da bacia, além dos trabalhos de Sanford e Lange 
(1960), Northfleet et al. (1969), Schneider et al. (1974), Soares et al. (1978), Almeida (1980), Fulfaro et al. (1980) e Zalán et al. (1990), referentes principalmente à geologia regional da bacia, mais os trabalhos vinculados à PETROBRAS, como os de Milani (1997) e Milani et al. (2007), os quais foram adotados como a principal base da elaboração do presente capítulo sobre geologia regional.

Informações acerca das principais feições estruturais e estratigráficas da porção brasileira da Bacia do Paraná foram obtidas a partir de um programa de perfurações e de levantamentos geofísicos realizado pela PETROBRAS com a finalidade de mapear e identificar locais propícios à acumulação de hidrocarbonetos na bacia (Quintas et al. 1997). Segundo Yoshida e Gama Jr. (2006), de 1953 a 1974, foi desenvolvido um grande esforço sistemático de pesquisa por reservas de petróleo e gás natural na Bacia do Paraná, o qual teria sido principalmente motivado pela proximidade ao principal centro consumidor desses recursos no Brasil (regiões sul e sudeste). Ao longo desse período, foram perfurados 71 poços exploratórios e aplicados diferentes métodos de prospecção, geralmente de caráter experimental, tais como a aeromagnetometria, gravimetria e sísmica de reflexão. A realização dessas atividades, mesmo que estas estivessem limitadas a uma faixa territorial correspondente a $30 \%$ da extensão total da Bacia do Paraná e apesar de seus resultados pouco promissores para acumulação convencionais de hidrocarbonetos, contribuiu significativamente para a construção de um acervo acerca de informações dessa bacia.

\subsubsection{ARCABOUÇO TECTONO-ESTRUTURAL}

De acordo com Milani (2004), a principal problemática no estudo do entendimento da origem da Bacia do Paraná está relacionada às limitações na visualização de seu arcabouço profundo, na região denominada "calha central" da bacia, ao longo do eixo do rio Paraná. Esta é classificada como um rifte central, identificado por me io de dados geofísicos regionais (gravimetria, magnetometria, sísmica de reflexão, além de análises litoestratigráficas de testemunhos de sondagem) e que corresponde à uma proeminente depressão pré-devoniana (Figura 39) delimitada geograficamente pelo eixo da bacia de drenagem do rio Paraná, e geologicamente por falhamentos normais. Segundo a classificação de Marques et al (2003), o rifte central é constituído por um domínio ordovício-siluriano internamente compartimentado em uma série de altos e baixos estruturais. $\mathrm{O}$ autor também afirma que estas sucessões sedimentares pré-devonianas apresentam maiores espessuras em relação às demais por estarem 
condicionadas ao rifte central, o qual se estende por cerca de $600 \mathrm{Km}$ na direção SW-NE (do Paraguai à porção centro-norte da bacia).

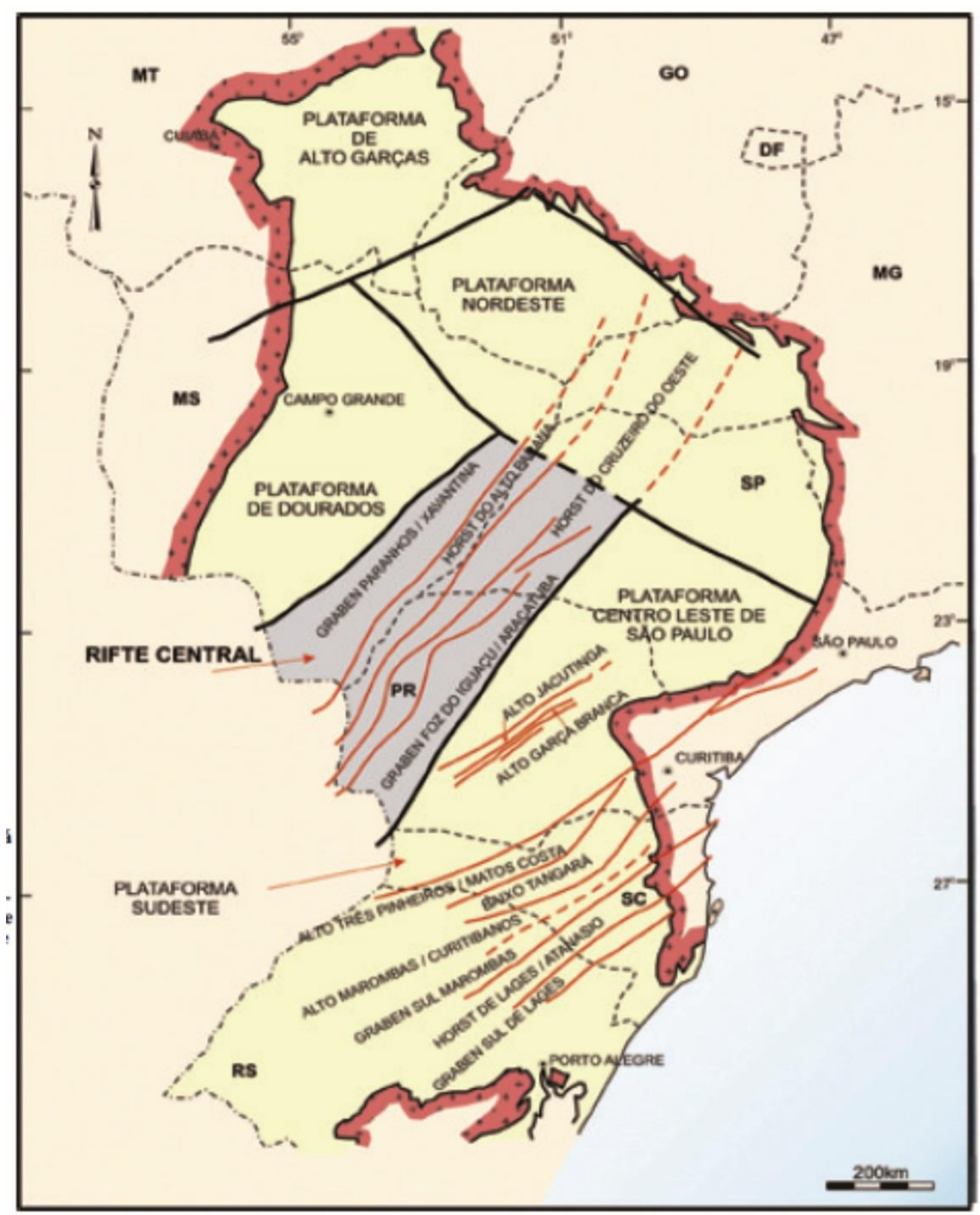

Figura 39 - Mapa do arcabouço tectônico da Bacia do Paraná. Marques et al. (2003) apud Milani (2004).

Fonte:

Posteriormente à formação do rifte central, a qual se associa à estiramentos decorrentes de aquecimento litosférico e subsidência mecânica promovida por falhas normais, ocorre uma etapa de subsidência térmica resultante da dissipação do calor acumulado anteriormente (Marques et al, 2003), permitindo a acomodação do pacote sedimentar devoniano e das seis grandes sequências do arcabouço estratigráfico da Bacia do Paraná, propostas por Milani (2007). 


\subsection{EVOLUÇÃO TECTONO-SEDIMENTAR}

A Bacia do Paraná se desenvolveu no interior do supercontinente Gondwana, inicialmente como forma de um amplo golfo, aberto para o paleo-oceano Panthalassa e posteriormente resultando em uma depressão intracratônica com episódios de orogenia (Zalán et.al. 1990). Segundo Milani et al (2007), a flexura litosférica por sobrecarga tectônica teria sido o principal mecanismo de subsidência ao longo da história evolutiva da bacia; interpretação que difere de outros autores como Zálan et al. (1990), que associa a implantação da sinéclise aos fenômenos tecnono-magmáticos do Ciclo Brasiliano e à consequente contração térmica, ou como Fulfaro et al. (1982 apud Milani et al. 2007), que determina um conjunto de calhas aulacogênicas, orientadas segundo a direção NW-SE, como precursoras da sedimentação cratônica.

Segundo Milani (1997), com base em análises do substrato pré-cambriano, "a implantação da bacia teria se dado na forma de depressões alongadas na direção NE-SW". Ainda segundo Milani (1997) e Ramos et al. (1986 apud Milani et al. 2007), a reativação de descontinuidades crustais presentes no embasamento da bacia, as quais correspondem ao arcabouço brasiliano e estão situadas sob o campo compressional da borda do continente em decorrência da orogenia Oclóyica do Neo-Ordoviciano, teriam propiciado a acomodação de sua primeira unidade cratônica: a supersequência Rio Ivaí, cujo pacote sedimentar tem seu topo assinalado por uma discordância neossiluriana.

A supersequência Paraná, de idade devoniana e caraterizada por sua uniformidade faciológica, teria se acumulado com a retomada da subsidência da bacia. O correspondente pacote sedimentar possui espessura variada e topo demarcado por sucessivos eventos erosivos que datam do Neodevoniano ao Carbonífero Médio. Foi identificada pelos autores uma lacuna na história evolutiva tecnoto-sedimentar da bacia do Paraná, representada por um hiato de cerca de 70 milhões de anos e correspondente ao período Mississipiano do tempo geológico, ausente no registro da bacia. Tal lacuna teria sido justificada através de fatores tectônicos associados à Orogenia Herciniana e/ou ao desenvolvimento intermitente de calotas de gelo sobre a ao redor da bacia, além do significativo rebaixamento do nível do mar relacionado a essas glaciações (Milani et al. 2007). De acumulação posterior à discordância neodevoniana, a Supersequência Gondwana I foi acumulada à medida que o processo de separação continental teve continuidade, com a migração de Gondwana para o norte e consequente deposição da sedimentação carbonífera. Seu pacote sedimentar corresponde a um ciclo transgressivo-regressivo completo: invasão e recuo de Panthalassa sobre o interior de Gondwana. Seu ciclo sedimentar é também influenciado pelo degelo das calotas polares presentes, caracterizado por fluxo de massa e 
ressedimentação. As condições de máxima inundação datam do Artinskiano e o encerramento da supersequência se dá no início do Triássico com sistemas deposicionais continentais. Milani et al (2007) afirmam que a acumulação de Gondwana I é concomitante ao progressivo fechamento da bacia do Paraná, o qual inicia o caráter intracratônico da bacia uma vez que esta é progressivamente aprisionada no interior continental de Gondwana durante o período Mesozóico.

O período Triássico na Bacia do Paraná é caracterizado por uma distensão generalizada do paleocontinente Gondwana em sua porção sul, contexto geológico no qual teria sido depositada a superquência Gondwana II, de ocorrência restrita à porção sul da bacia (no estado do Rio Grande do Sul e Uruguai) e de sedimentação similar à de bacias do tipo gráben. Condições erosivas de ampla escala ao longo do Mesozóico, associadas à abrasão eólica no interior do paleocontinente Gondwana, representam outra lacuna estratigráfica na bacia, ainda mais expressiva. A subsequente acumulação de campos de dunas a partir do período Jurássico, sucedidas pelo magmatismo eocretáceo decorrente da ruptura inicial do paleocontinente, compõe o conjunto sedimentar referente à supersequência Gondwana III (Milani et al 2007).

O período Eocretáceo no registro geológico da bacia é representado por intenso fendilhamento e magmatismo basáltico decorrente do rompimento do supercontinente Gondwana e pela consequente evolução do oceano Atlântico Sul. Esse evento está registrado na formação Serra Geral, a qual representa derrames basálticos e o fim da sedimentação extensiva no interior do supercontinente. Uma vez estabelecido o ajuste isostático da Plataforma Sul-Americana diante da abertura do oceano Atlântico, uma depressão se implantou sobre o pacote ígneo, na qual se acumularia o preenchimento sedimentar da supersequência Bauru, na área correspondente à Bacia do Paraná durante o Neocretáceo. Fernandes \& Coimbra (1996) não atribuem essa sequência neocretássea ao registro sedimentar da Bacia do Paraná, associando-a à uma diferente bacia: Bacia Bauru. Ao longo da deposição da supersequência Bauru a atividade ígnea também esteve presente; representada por corpos intrusivos frequentemente posicionados nas bordas setentrionais da bacia (Figura 40) (Milani et al.2007). 


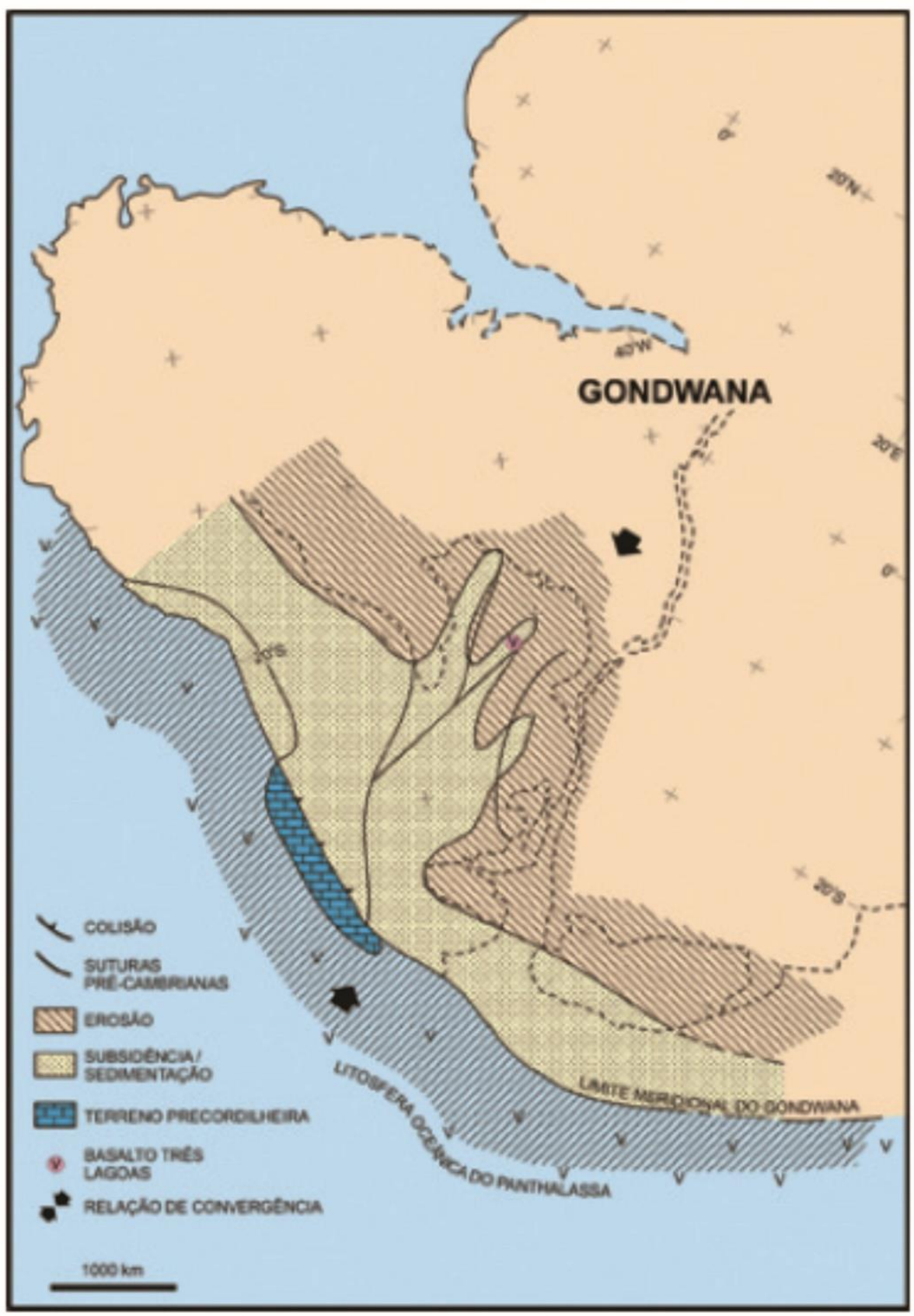

Figura 40 - Modelo paleotectônico da margem sul-ocidental de Gondwana durante o período NeoOrdoviciano (Orogenia Oclóyica): fase de subsidência inicial da Bacia do Paraná (delimitação em linha tracejada).

Fonte: Milani (2004).

\subsection{ARCABOUÇO LITOESTRATIGRÁFICO}

\subsubsection{UNIDADES LITOESTRATIGRÁFICAS}

\subsubsection{Supersequência Rio Ivaí}

Rochas sedimentares pré-devonianas foram conclusivamente datadas e mapeadas na Bacia do Paraná apenas na década de 1970, inicialmente no flanco norte da bacia por meio de amostragem e nas demais porções por correlações. Essas rochas correspondem a sequências 
sedimentares e magmáticas que obedecem à classificação de Milani (1997) como Supersequência Rio Ivaí, nomeada a partir do rio homônimo presente na porção noroeste do estado do Paraná e cujo um poço estratigráfico perfurado reflete a litologia mencionada e também presente na literatura geocientífica com diferentes denominações, tais como: Sequência Ordovício-Siluriana, Sequência Tectonossedimentar Ordovício-Siluriana, ou Grupo Rio Ivaí. Esta corresponde à unidade geológica mais antiga identificada na Bacia do Paraná, diretamente sobressequente ao embasamento da sinéclise. O topo da sequência é demarcado por uma discordância de escala regional que delimita a porção superior da Sequência Rio Ivaí, representada por estratos eossilurianos, e o embasamento da supersequência seguinte, de estratos eodevonianos (Formação Furnas). O pacote sedimentar ocorre no interior da bacia desde o estado de Santa Catarina aos estados do Mato Grosso e Goiás, apresentando uma tendência regional de espessamento em direção oeste e prolongando-se ao Paraguai oriental, onde é representado, por correlação litoestratigráfica, pelas formações Caacupé e Itacurubi, onde atingem espessuras de aproximadamente 1000 metros (Milani et al.2007).

Milani et al (2007) descrevem a sequência de fácies da Supersequência Rio Ivaí como representante do primeiro ciclo transgressivo-regressivo da sedimentação cratônica da bacia do Paraná; sedimentação essencialmente marinha cuja porção transgressiva se estende desde a base da unidade até os pelitos fossilíferos da formação Vila Maria, indicativos da inundação máxima desse ciclo sedimentar. Do intervalo de máxima inundação ao topo da unidade se manifesta a porção regressiva da sedimentação, que apresenta pouca expressividade no território brasileiro devido à atividade erosiva associada à discordância "pré-Formação Furnas"; mas se encontra bastante presente no Paraguai, correspondendo aos arenitos finos, micáceos e fossilíferos da Formação Cariy.

O pacote Rio Ivaí é constituído por 3 unidades litoestratigráficas, são estas as formações: Alto Garças, Iapó e Vila Maria (Assine et al.1994 apud Milani et al.2007).

\subsection{Formação Alto Garças}

Milani (1997) descreve a Formação Alto Garças como um pacote sedimentar de espessura máxima em torno de 300 metros e de composição essencialmente arenosa com inclusões basais de conglomerados quartzosos ou arenitos conglomeráticos com estratificação cruzada. A litologia é representada por arenitos quartzosos de granulação fina à grossa, pouco feldspáticos, que podem apresentar variações síltico-argilosas e de coloração avermelhada nas porções superiores dos pacotes. Estruturalmente a formação é caracterizada pelo registro de 
paleocorrentes fluviais, representadas por estratificações cruzadas recorrentes ao longo da base da unidade, cuja análise de afloramentos no flanco ocidental da bacia indica orientação no sentido sudoeste (Milani et al.2007).

De acordo com Milani (1997), a Formação Alto Garças apresenta icnofósseis do gênero Skolithos, presentes em testemunhos de sondagem no poço estratigráfico homônimo à formação. Entretanto, o conteúdo fossilífero da unidade não é significativo, não sendo suficiente para a determinação de sua idade.

\subsection{Formação Iapó}

Segundo Milani et al. (2007), a Formação Iapó é constitutída por diamictitos de matriz síltico-arenosa de coloração variada. A presença de clastos de natureza diversa também caracteriza a formação. Os diamictitos da Formação Iapó estão amplamente distribuídos ao longo da Bacia do Paraná, sendo correlacionados estratigraficamente desde o flanco setentrional à porção centro sul da bacia, já no Estado do Paraná. O contato entre essa formação e sua subsequente (Formação Alto Garças) é observado no pacote sedimentar de maneira abrupta, fato que indica uma descontinuidade no registro da sedimentação na bacia. O contato superior é com os depósitos pelíticos fossilíferos da Formação Vila Maria.

\subsection{Formação Vila Maria}

Descrita inicialmente na porção sudoeste do Estado de Goiás por Faria (1982 apud Milani et al. 2007) como um pacote sedimentar cratônico que inclui, em sua base, diamictitos seguidos de folhelhos fossilíferos e arenitos, intercalados com siltitos, em sua porção superior; representando toda a sequência estratigráfica sotoposta à Formação Furnas. Posteriormente descrita por Assine et al (1994 apud Milani et al.2007), a Formação Vila Maria foi restringida ao pacote pelítico fossilífero, tendo os diamictitos subtraídos da formação por terem sido correspondentes à formação anterior (Formação Iapó). Esse pacote pelítico possui granulação gradativa a frações arenosas em sua porção superior, e totaliza uma espessura média em poucas dezenas de metros. A litologia é representada por folhelhos micáceos de coloração avermelhada e aspecto ferruginoso; localmente de coloração cinza escura com elevado conteúdo fossilífero. Na porção superior do pacote, a litologia é representada por arenitos e siltitos cuja estruturação corresponde a estratificações cruzadas do tipo hummocky (Milani et al.2007). Faria (1982) descreve a presença de gretas de contração no intervalo superior da formação, sugerindo uma eventual exposição subaérea da superfície deposicional.

No contexto de registros fósseis, a Formação Vila Maria, juntamente com sua correspondente no Paraguai, Formação Vargas Peña, representa o conteúdo fossilífero 
característico do intervalo siluriano na Bacia do Paraná. São registradas nessas unidades megafósseis marinhos, tais como: graptólitos, trilobitas, braquiópodos, gastrópodos, biválvios e ostracodes; além de palinomorfos, tais como: quitinozoários, miósporos e acritarcas (Milani et al.2007). Fósseis de graptólitos (dos gêneros Monograptus e Diplograptus), quitinozoários e miósporos são os de maior importância bioestratigráfica e de maior relevância na determinação da idade da formação; a qual foi posicionada no intervalo estratigráfico do Eossiluriano por meio dessa associação, confirmada por meio de datação absoluta (Rb-Sr) dos folhelhos (435,9 $\pm 7,8 \mathrm{Ma}$ ) por Mizusaki et al (2002 apud Milani et al.2007), e equivalente à idade indicada pelos graptólitos e palinomorfos da correspondente paraguaia, Formação Vargas Peña.

\subsubsection{Supersequência Paraná}

Pacotes sedimentares devonianos, que ocorrem na Bacia do Paraná na porção sul do Brasil, têm sido temas de investigação geocientífica de longa data; inicialmente descritos por Derby (1878 apud Milani et al. 2007) e classificados por Oliveira (1912 apud Milani et al.2007) como sequência devoniana da bacia sob as seguintes denominações: "Grés das Furnas", "Xistos de Ponta Grossa" e "Grés de Tibagi”, sendo também conhecido como Grupo Paraná, Sequência Tectonossedimentar Devoniana-Mississipiana, Sequência Devoniana e Supersequência Paraná (Milani, 1997). O pacote sedimentar devoniano apresenta espessura máxima de aproximadamente 800 metros e estende-se ao longo de toda a bacia, onde, geralmente, se encontra sobreposto aos estratos ordovício-silurianos do Grupo Ivaí, ou localmente sobre o embasamento da sinéclise; até o Paraguai oriental. A base do pacote é delimitada por uma discordância, a qual configurou a deposição da porção inferior do pacote de maneira regular e aplainada, representada, segundo Milani et al.(2007) por um blanket sedimentar arenoso de cerca de 250 metros de espessura ao longo de toda a sua área de ocorrência. $\mathrm{O}$ topo do pacote também é delimitado por uma discordância; sendo esta de escala regional e datada do final do período Devoniano ao Carbonífero, e a qual subtraiu registros desse intervalo na bacia. A divisão do Grupo Paraná se dá em duas unidades: um pacote arenoso inferir, denominado Formação Furnas, e outro pelítico, sobreposto, denominado Formação Ponta Grossa (Milani et al. 2007).

Estratigraficamente, a Supersequência Paraná corresponde ao segundo ciclo transgressivoregressivo da Bacia do Paraná; sendo a Formação Furnas a assinatura transgressiva e o pacote pelítico da Formação Ponta Grossa o registro de condições de mar alto localmente pontuadas por progradações arenosas; a mais expressiva dessas progradações é correspondente ao Membro Tibagi. Essa sequência litológica é a representação da primeira grande inundação do 
período Devoniano (Praguiano ao Eo-emsiano); sendo o afogamento marinho da bacia persistente até o período Frasiano (Milani et al.2007). Os autores também descrevem um segundo episodio de expansão marinha durante o Mesodevoniano (Eifeliano ao Givetiano), a qual teria resultado na conexão entre as bacias Paraná e Parnaíba, fato evidenciado por correlação paleontológica de megafósseis e palinomorfos.

\subsection{Formação Furnas}

Milani et al.(2007) descrevem a Formação Furnas como "uma sucessão de arenitos quartzosos brancos, médio a grossos, cauliníticos e exibindo estratificações cruzadas de várias naturezas". Também é descrita a presença de leitos conglomeráticos, com cerca de 1 metro de espessura, ao longo da base do pacote. Na porção intermediária da formação, domina a presença de arenitos de granulação média, intercalados a delgadas sequências de siltitos e folhelhos moscovíticos, representando um intervalo bastante estratificado da formação e estruturalmente caracterizado por estratificações cruzadas do tipo espinha de peixe (Assine, 1996 apud Milani et al.2007). Já na porção superior da unidade, estão mais presentes arenitos de granulação média a grossa, também localmente intercalados a arenitos muito finos com estratificação cruzada do tipo hummocky; e progressivamente mais argilosos em direção ao topo, representando uma passagem gradacional para a formação pelítica sobresequênte: Formação Ponta Grossa (Milani et al.2007).

Segundo Assine (1996), os arenitos da Formação Furnas representam o encerramento de um ciclo de rico conteúdo fossilífero na bacia, fato que favorece sua hipótese acerca da acumulação em plataforma rasa. Devido essa escassez fossilífera, a porção inferior da unidade não foi consensualmente datada; sendo possivelmente atribuída ao final do Siluriano. A presença de pelitos na porção superior da unidade, nos quais estão contidos vegetais continentais e miósporos do grupo das Psilophytales, mudam o quadro problemático de datação, posicionando o topo da Formação Furnas no Lochkoviano superior (Gerrienne et al.2001 apud Milani et al.2007). A associação dessa datação com a transição gradacional entre as formações Furnas e Ponta Grossa confirma a atribuição da Supersequência Paraná, inteiramente ou quase sua totalidade, ao período Devoniano.

\subsection{Formação Ponta Grossa}

A Formação Ponta Grossa é representada por formações pelíticas devonianas que apresentam profundidade em torno de 600 metros em subsuperfície e 300 metros remanescentes 
em afloramentos; estendendo-se ao longo de toda a porção brasileira da Bacia do Paraná e prolongando-se ao Uruguai, onde recebe a denominação de Grupo Durazno (Milani et al.2007). A formação foi inicialmente descrita no Estado do Paraná e é subdividida em 3 membros estratigráficos: Jaguariaíva, Tibagi e São Domingos (Lange \& Petri, 1967 apud Milani et al.2007). O membro inferior, Jaguariaíva, corresponde à inundação sobre os sistemas transicionais da porção superior da formação sotoposta, Formação Furnas, e é representado por folhelhos, com cerca de 100 metros de espessura, com presença de lentes areníticas estratificadas e que apresentam retrabalhamento por ondas. Na porção superior do pacote (nos 20 metros superiores), estão presentes folhelhos negros laminados e carbonosos, os quais representam potenciais geradores de hidrocarbonetos na porção central da bacia, além de representarem um importante marco na correlação estratigráfica (Milani et al.2007). O membro Tibagi é de composição areno-síltica e corresponde à porção intermediária do pacote sedimentar; representa um contexto regressivo de progradação de sistemas deltaicos oriundos do aporte sedimentar arenoso da borda nordeste da bacia (Andrade \& Camarço, 1982 apud Milani et al.2007). O membro São Domingos é dominantemente representado por folhelhos e corresponde a uma inundação de grande escala que encerra o registro devoniano da sinéclise (Milani et al.2007).

A bioestratigrafia da Formação Ponta Grossa foi incialmente descrita por Clarke (1913 apud Milani et al.2007), autor considerado um marco na classificação de macrofósseis na unidade; seguido por Lange \& Sommer (1954 apud Milani et al.2007), os quais sintetizaram o conhecimento acerca da paleofauna e paleoflora devoniana na bacia. O conteúdo fossilifero, referente à paleofauna, é representado, predominantemente, por invertebrados marinhos, tais como: braquiópodos, trilobitas, biválvios, gastrópodos, anelídeos e equinodermos. Já a paleoflora é representada por Psilophytales, Lepidodendrales, Lycopsidales e Hyniales, os quais evidenciam o avanço evolutivo do período Devoniano. A formação foi precisamente datada por meio de zoneamentos palinoestratigráficos baseados em quitinozoários e miósporos, que atribuíram a deposição da Formação Ponta Grossa aos períodos Praguiano ao Neofrasiano não terminal (Milani et al.2007).

\subsubsection{Supersequência Gondwana I}

A Supersequência Gondwana I corresponde ao maior volume sedimentar da Bacia do Paraná, sendo de ocorrência quase que contínua ao longo do perímetro da sinéclise e atingindo 
uma espessura máxima em torno de 2.500 metros. Seu pacote sedimentar é predominantemente paleozóico, e tem sido foco de estudos na bacia devido à ocorrência de depósitos de valor econômico atribuído, tais como leitos de carvão mineral e depósitos de urânio (Formação Rio Bonito), e de rochas geradoras e reservatórios de hidrocarbonetos. Inicialmente descrita por Derby (1878) e White (1908), a supersequência é também conhecida como Sequência Tectonossedimentar Pensilvaniana-Permiana ou como Sequência Carbonífero-Eotriássica.

A unidade engloba uma grande variedade de condições deposicionais inserida em um contexto geológico eocarbonífero, que abrange desde influência glacial até condições áridas continentais de campos de dunas, indicando a chegando do Mesozóico. Essa supersequência, sob a ótica litoestratigráfica, divide-se nos seguintes pacotes sedimentares: Grupo Itararé (Formações Lago Azul, Campo Mourão e Taciba) e Formação Aquidauana, Grupo Guatá (Formações Rio Bonito e Palermo), Grupo Passa Dois (Formações Irati, Serra Alta, Teresina e Rio do Rastro) e Formações Pirambóia e Sanga do Cabral.

Durante o período Eocarbonífero a porção sul-ocidental do supercontinente Gondwana esteve exposta a elevadas latitudes e, consequentemente, foi sujeitada à extensa glaciação continental, fator inibidor à deposição sedimentar e refletiu na ausência de registro no intervalo entre os estrados neodevonianos da Formação Ponta Grossa e os estratos neocarboníferos do Grupo Itararé e Formação Aquidauana. A sedimentação foi retomada à medida que ocorreu a progressiva migração do paleocontinente em direção norte, afastando assim o foco da glaciação (Milani et al.2007). Esses depósitos glaciogênicos da Bacia do Paraná são representados por diamictitos maciços ou estratificados, com presença de seixos e blocos de litologia diversa, evidenciando o transporte sedimentar por geleiras; e por fácies arenosas maciças, gradadas ou com ondulações unidirecionais correspondentes a um contexto de sedimentação turbidítica. Os pacotes pelíticos da unidade foram associados ao processo de decantação, quando maciços, ou de sedimentação turbidítica quando laminados. Outros litotipos glaciogênicos como ritmitos (varvitos) e tilitos (localmente no Grupo Itararé) também estão presentes, embora em menor escala (Rocha-Campos, 1967 apud Milani et al.2007). A seção glaciogênica da Supersequência Gondwana I está mais presente na porção centro-norte da bacia, onde atinge a espessura máxima em torno de 1.300 metros (Milani et al.2007).

A partir do fenômeno de deglaciação, o consequente aumento no nível relativo do mar foi registrado por Lavina \& Lopes (1987 apud Milani et al.2007) como a "transgressão permiana" da bacia; na forma de estratos ora arenosos ora pelíticos que sucedem o pacote glaciogênico. Estes foram subdivididos em 3 membros, de acordo com a predominância litológica, sendo estes: Triunfo, Paraguaçu e Siderópolis (Schneider et.al.1974 apud Milani et.al.2007). No 
primeiro membro são característicos os indícios de retrabalhamento dos lobos deltaicos por ações de marés; no segundo fica evidenciada a influência marinha, representada por pacotes pelíticos de espessura considerável; enquanto que o terceiro membro é caracterizado por restrição lagunar e pelo desenvolvimento de turfeiras, as quais originaram os depósitos de carvão do Membro Siderópolis (Milani et al.2007). O pacote sedimentar associado ao degelo da calota gondwânica apresenta, aproximadamente, 1.500 metros de espessura, é atribuído ao Grupo Itararé, e representado pela Formação Aquidauana na porção norte da bacia; sendo litologicamente constituído por diamictitos intercalados a arenitos, caracterizados pela presença de elementos glacioterrestres quanto glaciomarinhos. O padrão de sedimentação do grupo Itararé, de norte para o sul, é sucedido por uma sedimentação onlap de sul para norte, a qual caracteriza a deposição do Grupo Guatá e sendo as condições de máximo paleobatimétrico registrados na Formação Palermo (início do Neopermiano). A seção sedimentar sobresequente é de natureza regressiva e atribuída ao Grupo Passa Dois, evidenciada pelos presentes depósitos eólicos eotriássicos (Formações Serra do Cabral e Pirambóia) (Milani \& Ramos, 1998).

A Formação Rio Bonito é constituída por níveis marinhos, geralmente representados por tempestitos, ou por grandes pacotes pelíticos (Membro Paraguaçu). A porção superior do pacote compreende arenitos de granulação fina, siltios e siltitos carbonosos intercalados a estratos de carvão (de ocorrência mais concentrada na porção meridional da bacia).

A Formação Palermo é litologicamente constituída por siltitos e siltitos arenosos, de coloração cinza-amarelada, caracterizados pela presença de bioturbações. Localmente também estão presentes arenitos finos com estratificação do tipo hummocky, dispostos de forma lenticular ao longo da formação; e folhelhos de coloração cinza-escura, os quais são correlacionados à inundação máxima da Supersequência Gondwana I. Com base em análises bioestratigráficas, por meio de zoneamento palinológico, a formação está temporalmente posicionada no Artinskiano; e o conjunto a qual pertence, Grupo Guatá, entre o Sakmariano e Artinskiano (Souza, 2006).

A Formação Irati corresponde a acumulações de carbonatos e evaporitos na porção norte da Bacia do Paraná, e de folhelhos betuminosos na porção sul; as quais foram decorrentes da deposição em um contexto ambiental hipersalino, desenvolvido no interior na bacia devido um evento de restrição à circulação de águas entre o paleoceano Panthalassa e a sinéclise (Milani et al.2007). Os folhelhos negros dessa formação se destacam por seu elevado nível de conteúdo orgânico, atingindo valores consideráveis (ordem de 23\%), classificando-os como potenciais rohcas geradoras de hidrocarbonetos na bacia. O conteúdo fossilífero da formação é singular, sendo a paleofauna de vertebrados representada pelos répteis dos gêneros Mesosaurus e 
Stereosternum, os quais sugeriam, por meio de correlações paleontológicas com a África do Sul, a teoria da deriva continental desde a década de 1920. Por meio dessa correlação bioestratigráfica e por datações em zircões presentes em cinzas vulcânicas, a geocronologia da Formação Irati posiciona-se no Neo-Artinskiano (Santos et al.2006).

A formação sobresequente, Formação Serra Alta, corresponde a um pacote de folhelhos cinza-escuros de laminação fina; os quais representam um contexto deposicional de baixa energia e consequente deposição de argila associado ao "afogamento do golfo Irati". Essa sequência pelítica equivale à última importante incursão marinha presente na Bacia do Paraná (Milani et al.2007).

O Grupo Passa Dois, de sedimentação pós-Serra Alta, desenvolveu-se em um contexto regressivo de ampla escala, onde sistemas continentais passam a ser mais participativos na acumulação sedimentar e resultam no progressivo assoreamento da bacia. Nesse contexto, depósitos predominantemente pelíticos com traços de ação de marés (Formação Teresina) são sucedidos por um sistema progradacional de red beds e de lobos deltaicos, pelitos lacustres, depósitos fluviais e arenitos eólicos (Formação Rio do Rastro), datadados do Permiano Superior ao início do Triássico e amplamente distribuídos de noroeste a sudeste da bacia (Lavina, 1988 apud Milani et al.2007). A Formação Teresina possui um equivalente na porção da bacia referente ao Estado de São Paulo, Formação Corumbataí, sendo ambas correspondentes a um amplo sistema de marés. A formação sobresequente, Rio do Rastro, possui um equivalente lateral, Formação Sanga do Cabral, as quais representam o "avanço de sistemas continentais sobre os remanescentes lacustres do Grupo Passa Dois”. A Formação Sanga do Cabral é análoga á Formação Pirambóia, situada na porção setentrional da bacia, e equivalem à depósitos fluviais e eólicos (Milani et al.2007).

De modo geral, a Supersequência Gondwana I corresponde a um ciclo transgressivoregressivo completo na Bacia do Paraná; sendo sua sedimentação iniciada por um pacote glacial pensilvaniano na base, seguido por registros de afogamento marinho máximo no Artinskiano (Formação Palermo) e encerrado pela deposição de depósitos continentais que viriam a preencher a sinéclise no início do período Mesozóico (Milani et al.2007).

\subsubsection{Supersequência Gondwana II}

A Supersequência Gondwana II, descrita por Milani (1997), corresponde a um sistema triássico representado por um pacote sedimentar pelítico fossilífero, denominado Formação Santa Maria, de ocorrência limitada ao sul da Bacia do Paraná (Estado do Rio Grande do Sul) 
e sem equivalência com demais porções da bacia. Essa sequência pelítica se encontra inserida em uma sessão espessa, dominantemente arenosa e afossilífera, análoga ao intervalo permiano entre as formações Sanga do Cabral e Botucatu (Neojurássico-Eocretáceo). A litologia da Formação Santa Maria é basicamente constituída por red beds. Seu conteúdo fossilífero é constituído por principalmente por vertebrados (répteis dos grupos Dicynodontia, Cynodontia, Pseudosuchia, Rhynnchocephalia e Saurischia), além de plantas fósseis e invertebrados (Crustacea e Insecta), com base nos quais a formação foi cronologicamente posicionada entre o Mesotriássico e o Neotriássico (Milani et al.2007).

No pacote sedimentar referente à Formação Santa Maria, observa-se que este apresenta um contato basal abrupto com os arenitos da formação antecedente. Minali et al.(2007) interpretam esse contato como com "uma rápida transgressão lacustre", indicando um "episódio de afundamento acelerado do substrato e desenvolvimento de uma bacia faminta", a qual seria posteriormente preenchida por aportes arenosos progradacionais, Com base nessa análise, a formação pode ser resumidamente descrita como um conjunto de pelitos lacustres e progradações arenosas, o qual se apresenta recoberto, também por contato abrupto, pelos arenitos das formações sobresequêntes e equivalentes Tacuarembó, no Uruguai, e Botucatu, no Rio Grande do Sul. Em sua interpretação, os autores associam essa subsidência mesoneotriássica na Bacia do Paraná com o desenvolvimento de grábens distensivos assimétricos, os quais teriam acomodado a drenagem fluvial sobre a rampa flexural do sistema, acumulando pelitos nas porções mais subsidentes. Ou seja, a Supersequência Gondwana II representa a sedimentação lacustre-fluvial decorrente de um evento de subsidência nos grábens triássicos situados na porção sul brasileira da Bacia do Paraná (Milani et al.2007).

\subsubsection{Supersequência Gondwana III}

A Supersequência Gondwana III, também denominada de Sequência Jurássica-Eotriássica (Milani et al. 1994), se apresenta amplamente distribuída ao longo da Bacia do Paraná e é constituída por um pacote sedimentar continental representado predominantemente por fácies eólicas (Formação Botucatu) e por magmatitos (Formação Serra Geral).

A Formação Botucatu é litologicamente constituída por arenitos de granulação média à fina, bem selecionados (elevado grau de esfericidade) e de coloração rosada com aspecto fosco; estruturalmente caracterizados por estratificações cruzadas tangenciais. Faciológicamente, a formação corresponde ao chamado 'deserto Botucatu", reconhecido através do retrabalhamento eólico sobre depósitos fluviais subjacentes ao campo de dunas (Milani et al.2007). Nesse pacote 
sedimentar também estão presentes frações lenticulares de arenitos médios a grossos associados à arenitos conglomeráticos, representativos de episódios torrenciais em um contexto alúviofluvial; e de ritmitos arenosos ora sílticos argilosos caracterizados por sua estratificação planoparalela, indicativos de um ambiente lacustre (Milani et al.2007).

A Formação Serra Geral corresponde a uma ampla província magmática associada ao intenso vulcanismo fissural de ampla escala que afetou as bacias cratônicas sul-americanas durante o Mesozóico. Milani et al.(2007) associam essa atividade ígnea à campos tensoriais e à fenômenos endógenos que atuaram na fragmentação do palocontinente Pangea. Esses eventos são representados na Bacia do Paraná por espessas coberturas de lavas, redes de diques e múltiplos níveis de soleiras intrundidas nos estratos sedimentares paleozóicos. A formação também se apresenta amplamente distribuída ao longo da bacia e com uma espessura remanescente de cerca de 2000 metros. Litológicamente, a formação é constituída por basaltos toleíticos e andesitos basálticos, além da presença, em menor escala, de riolitos e riodacitos. Com base em análises geoquímicas de Bellieni et al. (1984) e Mantovani et al.(1985), variações composicionais estão presentes ao longo desse cobertura ígnea: na porção norte da bacia, predominam rochas enriquecidas em $\mathrm{TiO} 2$, sendo as da porção sul pobres nesse componente; fator decorrente do diferente grau de assimilação crustal por essa ascendência magmática. Datações realizadas por Renne et al.(1992 apud Milani et al.2007), através da técnica Ar/Ar, associadas à correlações estratigráficas, indicam que o magamtismo Serra Geral foi um evento temporalmente posicionado entre 137 e $126 \mathrm{Ma}$.

\subsubsection{Supersequência Bauru}

Descrita por Milani (1997) como uma unidade siliciclástica psamítica acumulada em um contexto semi-árido a desértico, a Supersequência Bauru se apresenta amplamente distribuída ao longo da Bacia do Paraná, abrangendo os estados de Minas Gerais, São Paulo, Mato Grosso, Mato Grosso do Sul, Goiás e Paraná, além da porção nordeste do Paraguai; totalizando uma área de ocorrência em torno de $370.000 \mathrm{~km}^{2}$ com cerca de 300 metros de espessura. O contato basal da formação com a sequência basáltica anterior ocorre por meio de uma discordância erosiva (não-conformidade). A porção inferior desse pacote sedimentar é representada por estratos delgados de aspecto brechóide e com clastos angulosos de basalto em uma matriz arenosa imatura.

A litoestratigrafia da Bacia do Paraná foi definida através de análises de testemunhos de sondagem, de amostras de afloramentos, e de interpretações de dados geofísicos, geoquímicos 
e petrográficos, obtidos por meio da empresa estatal Petróleo Brasileiro S.A. (Petrobrás), conforme a figura 41 .

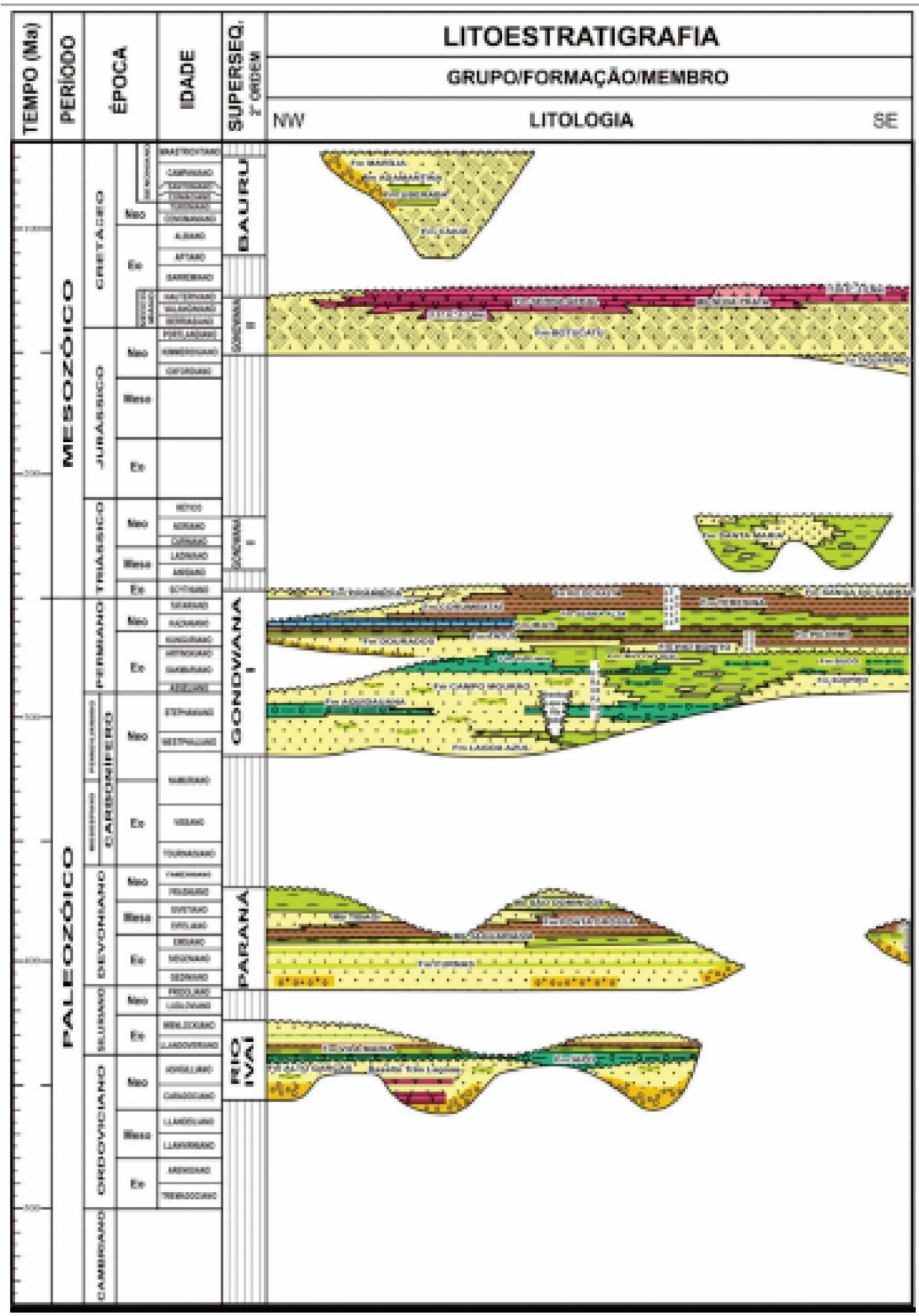


Figura 41 - Coluna estratigráfica da bacia do Paraná.

Fonte: Milani (2004).

\section{POTENCIAL PARA GERAÇÃO DE HIDROCARBONETOS}

A Bacia do Paraná apresenta dois principais sistemas petrolíferos de configuração convencional: formações Ponta Grossa - Itararé e formações Irati - Rio Bonito, sendo as formações pelíticas (Ponta Grossa - Devoniano; e Irati - Permiano) responsáveis pela geração de hidrocarbonetos. Em ambos os sistemas, a maturação da matéria orgânica, migração de fluidos e trapeamento de hidrocarbonetos são relacionados à colocação de corpos ígneos intrusivos (diques e soleiras), que datam do período Jurássico-Cretáceo (Arthur \& Soares, 2002).

Conforme abordado anteriormente, a formação geológica Ponta Grossa data do período Devoniano e é litológicamente constituída por folhelhos, folhelhos siltosos, e siltitos localmente carbonosos; fossilíferos e micáceos, com intercalações de arenitos de coloração cinza clara. A caracterização geoquímica de amostras referentes à essa formação revelou teores de carbono orgânico total (COT) que variam de 1 a $3 \%$, sendo a média de 0,5 \%; com predominância de matéria orgânica de origem marinha (querogênio tipo II) na porção oeste da bacia, e de origem continental na porção leste (querogênio tipo III) A formação Ponta Grossa é classificada como comprovadamente geradora de gás natural e condensado de petróleo; atingindo níveis supermaturos em grande parte da bacia. $\mathrm{O}$ valor do potencial gerador de hidrocarbonetos $\left(\mathrm{S}_{2}\right)$ atinge valores na ordem de $6,6 \mathrm{mg}$ de $\mathrm{HC} / \mathrm{g}$ de rocha, e baixos valores de índice de hidrogênio (IH), baseados a partir da análise de reflectância de vitrinita, e que decorrem desse elevado estágio de maturação térmica em que se apresenta a formação (Arthur \& Soares, 2002) (Milani, 2004) (Azevedo da Silva, 2007).

A formação Irati, datada do Permiano, é constituída por folhelhos enriquecidos em matéria orgânica amorfa (favorável à geração de hidrocarbonetos líquidos). Análises geoquímicas revelam que o teor de carbono orgânico total (COT) na formação variam de 0,1 a $23 \%$, sendo a média de $2,0 \%$. Seu potencial para geração de hidrocarbonetos $\left(S_{2}\right)$ atinge valores entre 100 e $200 \mathrm{mgHC} / \mathrm{g}$ de rocha; sendo a matéria orgânica predominante de origem algácea (querogênio tipo I, sendo os tipos II e III também presentes). De modo geral, a formação Irati apresenta baixo grau de evolução térmica, com exceção no depocentro da bacia (rifte central), onde pode alcançar valores elevados de maturação em virtude da influência de corpos magmáticos intrusivos (Arthur \& Soares, 2002) (Milani, 2004) (Azevedo da Silva, 2007). 
Com base nessas informações, pode-se avaliar o potencial de geração de hidrocarbonetos não convencionais nas formações Irati e Ponta Grossa, Bacia do Paraná, visto que este coincide com o potencial para geração de hidrocarbonetos convencionais mas não requer a presença de trapeamento para a acumulação do petróleo: a baixa permeabilidade caraterística da litologia folhelhos- atua como reservatório e selante do sistema petrolífero, caracterizando-o como não convencional.

\subsection{Caracterização Geológica das Formações Irati e Ponta Grossa}

De acordo com estudos realizados por Azevedo da Silva (2007), pode-se concluir que as formações geológicas Irati e Ponta Grossa, são as formações com potencial para ocorrência de hidrocarbonetos na Bacia do Paraná. A partir de análises geoquímicas, a autora sumarizou os dados obtidos através de testemunhos de sondagem e amostras de afloramentos ao longo da bacia (Figura 42) (Tabela 9) e avaliou o potencial de geração de hidrocarbonetos nessas formações. 


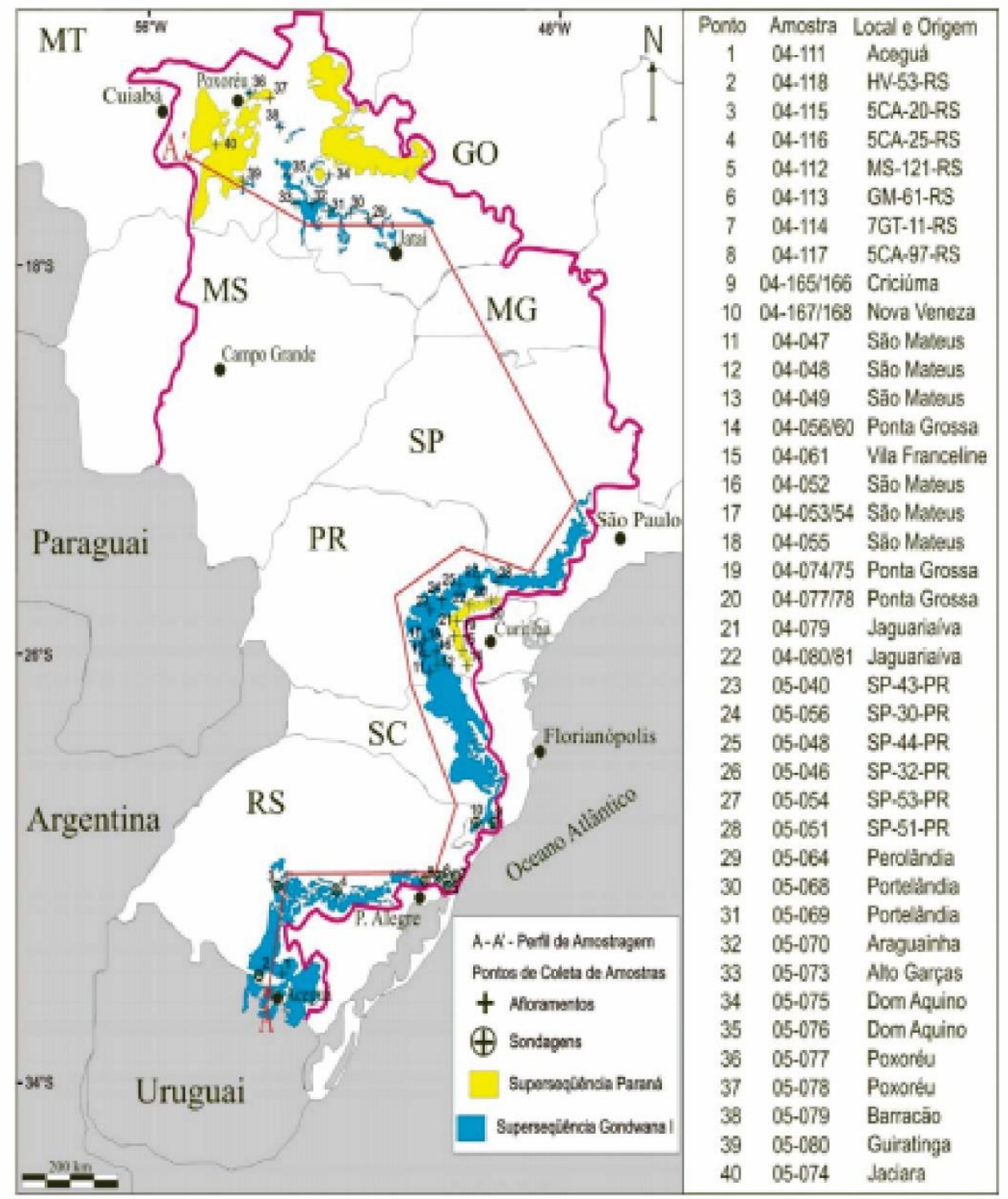

Figura 42 - Mapa de localização dos poços exploratórios presentes na Bacia do Paraná e dos pontos amostrados referentes ás formações Irati e Ponta Grossa.

Azevedo da Silva (2007).

Fonte:

Tabela 9 - Resultados obtidos em análises de COT, pirólise Rock-Eval em amostras das formações Irati e Ponta Grossa, Bacia do Paraná. 


\begin{tabular}{|c|c|c|c|c|c|c|c|c|c|c|c|}
\hline Identificação & Formação & $\begin{array}{l}\text { COT } \\
(\%)\end{array}$ & S1 & S2 & $\mathrm{S} 1+\mathrm{S} 2$ & S3 & Tmax & HI & OI & IP & $\begin{array}{c}\text { Ro } \\
(\%)\end{array}$ \\
\hline 04-056 & Ponta Grossa & 1,81 & 0,34 & 7,97 & 8,31 & 0,06 & 444 & 440,33 & 3,31 & 0,04 & 0,54 \\
\hline 04-074 & Ponta Grossa & 1,19 & 0,12 & 1,61 & 1,73 & 0,60 & 437 & 135,29 & 50,42 & 0,07 & 0,55 \\
\hline 04-077 & Ponta Grossa & 1,12 & 0,08 & 2,55 & 2,63 & 0,11 & 445 & 227,68 & 9,82 & 0,03 & 0,48 \\
\hline 04-079 & Ponta Grossa & 1,00 & 0,13 & 0,01 & 0,14 & 0,23 & 437 & 1,00 & 23,00 & 0,93 & 0,53 \\
\hline 05-077 & Ponta Grossa & 2,53 & 0,97 & 6,20 & 7,17 & 0,34 & 427 & 225,45 & 12,36 & 0,14 & 0,55 \\
\hline 04-049 & Irati & 21,00 & 4,91 & 131,16 & 136,07 & 8,02 & 419 & 624,57 & 38,19 & 0,04 & 0,51 \\
\hline 04-055 & Irati & 13,40 & 5,73 & 99,87 & 105,60 & 4,76 & 424 & 745,30 & 35,52 & 0,05 & 0,51 \\
\hline 05-079b & Irati & 3,31 & 1,58 & 10,11 & 11,69 & 0.65 & 388 & 368,98 & 23,72 & 0,14 & 0,56 \\
\hline 05-064 & Irati & 2,41 & 8,41 & 63,13 & 71,54 & 0,04 & 337 & 756,45 & 0.98 & 0,12 & 0,45 \\
\hline $04-165$ & Irati & 5,49 & 1,39 & 66,27 & 67,66 & 0,42 & 432 & 726,64 & 4,60 & 0,02 & 0,52 \\
\hline $04-166$ & Irati & 1,28 & 1,66 & 51,55 & 53,21 & 0,27 & 429 & 991,34 & 5,19 & 0,03 & 0,47 \\
\hline 04-117 & Irati & 1,34 & 0,14 & 1,24 & 1,38 & 0,43 & 431 & 92,54 & 32,08 & 0,10 & 0,58 \\
\hline $04-118$ & Irati & 1,68 & 0,24 & 2,85 & 3,09 & 0,62 & 417 & 169,64 & 36,9 & 0,08 & 0,56 \\
\hline
\end{tabular}

Fonte: Azevedo da Silva (2007).

Com base nessa análise de dados, pode-se observar que a formação Irati apresenta, apara as amostras analisadas, elevado teor de matéria orgânica com condições médias à altas de preservação dessa matéria orgânica, enquanto que a formação Ponta Grossa apresenta condições baixas à médias de preservação. Observa-se também a influência de intrusões basálticas na maturação das rochas: amostras coletadas nas proximidades de rochas ígneas intrusivas possuem baixos teores de COT, condição decorrente do craqueamento térmico da matéria orgânica presente (Azevedo da Silva, 2007). A autora também identificou o tipo de querogênio predominante nas amostras: tipo I na formação Irati e tipo II na formação Ponta Grossa. Os valores de Tmáx (temperatura em que ocorre o máximo da geração de hidrocarbonetos) e de IP (índice de produção), obtidos através da pirólise Rock-Eval evidenciaram, para amostras da formação Irati sem influência de corpos ígneos intrusivos, baixo grau de evolução térmica, enquanto amostras da formação Ponta Grossa apresentam elevado grau de maturidade termal (rochas supermaturas), conforme sumarizado na Tabela 10.

Tabela 10 - Aplicação dos parâmetros essenciais à ocorrência de gás natural não convencional às formações geológicas Irati e Ponta Grossa, Bacia do Paraná. 


\begin{tabular}{|c|c|c|}
\hline Parâmetros Comparativos & Irati & Ponta Grossa \\
\hline Idade Geológica & Permiano & Devoniano \\
\hline Litologia & $\begin{array}{l}\text { Folhelhos negros enriquecidos em } \\
\text { matéria orgânica amorfa e com } \\
\text { lentes carbonáticas; calcáreos } \\
\text { dolomíticos. }\end{array}$ & $\begin{array}{l}\text { Folhelhos negros laminados e } \\
\text { carbonosos, folhelhos siltosos, } \\
\text { siltes localmente carbonosos, } \\
\text { fossilíferos e micáceos, com } \\
\text { intercalações areníticas. }\end{array}$ \\
\hline $\begin{array}{l}\text { Composição } \quad \text { Mineralógica } \\
\text { Predominante (\% volume) }\end{array}$ & $\begin{array}{l}\text { Sílica (40-55), Argilominerais (45- } \\
60)\end{array}$ & $\geq$ Sílica \\
\hline Mineralogia (\% volume) & $\begin{array}{l}\text { Mica e argilominerais (60-70), } \\
\text { titanita e rutilo (1-8), matéria } \\
\text { orgânica (20-30) }\end{array}$ & - \\
\hline Área $\left(\mathrm{km}^{2}\right)$ & - & \\
\hline Espessura (m) & $\leq 20$ & 80 (em média de 20 a 60) \\
\hline Profundidade (m) & $\leq 3.000$ & $\leq 3.500$ \\
\hline $\begin{array}{l}\text { Tipo de Querogênio } \\
\text { Predominate }\end{array}$ & I, II e III (tipos I e II predominante) & $\begin{array}{l}\text { II e III (tipo II predominante na } \\
\text { porção oeste da bacia) }\end{array}$ \\
\hline Ro $(\%)$ & $1,1-1,6$ & $\geq 1,35$ \\
\hline $\operatorname{COT}(\%)$ & $1-23$ (média de $\leq 2$ ) & $1-3$ (média de 0,5 ) \\
\hline Tmáx $\left({ }^{\circ} \mathbf{C}\right)$ & $\leq 440$ & $430-500$ \\
\hline Maturidade Termal & $\begin{array}{l}\text { Associada à taxa de soterramento: } \\
\text { maior no depocentro da bacia; e à } \\
\text { influência de corpos magmáticos } \\
\text { intrusivos. } \\
\text { predominantemente imaturas. }\end{array}$ & $\begin{array}{l}\text { Associada à taxa de soterramento } \\
\text { e à influência de corpos } \\
\text { magmáticos intrusivos. Rochas } \\
\text { predominantemente supermaturas } \\
\text { (domínio mais apropriado à } \\
\text { geração de gás natural não } \\
\text { convencional). }\end{array}$ \\
\hline $\begin{array}{l}\text { Classificação da } \quad \text { Bacia } \\
\text { Sedimentar }\end{array}$ & & \\
\hline $\begin{array}{l}\text { Paleoambiente Deposicional } \\
\text { Características do Reservatório } \\
(\%)\end{array}$ & $\begin{array}{l}\mathrm{S} 1=0,02-0,8 \mathrm{mgHC} / \mathrm{g} \text { rocha; } \mathrm{S} 2 \\
=100-200 \mathrm{mgHC} / \mathrm{g} \text { rocha; } \mathrm{S} 1+\mathrm{S} 2 \\
=0,2-0,8 ; \mathrm{IP} \leq 0,1\end{array}$ & $\begin{array}{l}\mathrm{S} 2=6,6 \mathrm{mg} ; \mathrm{S} 1+\mathrm{S} 2=\text { potencial } \\
\text { para gás natural; }\end{array}$ \\
\hline
\end{tabular}

A partir da análise dos dados coletados e dos parâmetros geológicos, geoquímicos e petrofísicos essenciais à ocorrência de gás natural não convencional (shale gas), fundamentados em campos comprovadamente produtores do recurso e em estudos de (Arthur \& Soares, 2002) (Milani, 2004) (Azevedo da Silva, 2007); pode-se concluir que:

- A Formação Irati apresenta potencial moderado para geração de gás natural não convencional, sendo este potencial concentrado em zonas mais profundas da bacia (depocentro). A Formação Irati se apresenta em baixo estágio de maturação termal, sendo necessário encontrar zonas em que a formação apresente maior espessura e proximidade de sills (corpos ígneos intrusivos de disposição horizontal cujo gradiente 
geotérmico favoreça à maturação da matéria orgânica), e distantes de diques e falhas (aumento brusco da temperatura e consequente craqueamento da matéria orgânica e perda do hidrocarboneto gerado);

- A Formação Ponta Grossa também apresenta potencial moderado para geração de gás natural não convencional. No entanto, comparativamente maior do que na Formação Irati em virtude de seu maior estágio de evolução termal, maior espessura e profundidade. Entretanto, é necessário encontrar zonas mais enriquecidas em matéria orgânica (sweet spots) e com maior grau de preservação desta (zonas afastadas de corpos ígneos intrusivos), condições presentes na porção mais oeste da bacia e com extensão para o Uruguai (Arthur \& Soares, 2002).

Segundo estudos de Amaral (2016), a formação Irati no Estado do Rio Grande do Sul, onde a direção geral das camadas gondwânicas é E-W, apresenta mergulho para norte obedecendo à configuração geral da bacia do Paraná. Entretanto, análises em furos de sondagem na região de São Gabriel (extremo sul do estado), indicam o início da inflexão das camadas para o sul, ou seja, a direção do Irati passa a ser NE com mergulho para NW na porção mais ao sul da bacia. Apesar de não encontrados dados referentes à direção e inclinação do Irati no Uruguai, a formação é descrita na bibliografia como de caráter lenticular e constantemente presente; muito embora seja descrita uma espessura de 70 metros, portanto, quase ou mais que o dobro do Irati do Brasil (onde apresenta espessura entre 20 e 40 metros), indicando tratar-se de uma formação contínua. Trabalhos de prospecção, realizados por empresas americanas desde 2009 em território uruguaio apontam indícios de ocorrência de hidrocarbonetos, principalmente de gás natural na região de La Paloma, Durazno (formação Cordobés); a cerca de 180 metros de profundidade. A exploração do recurso teve início em 2011, sendo fruto da parceria entre a empresa estatal ANCAP e a venezuelana PDVSA (Amaral, 2016).

No Uruguai, a sequência devoniana também evidencia um ciclo transgressivoregressivo, litologicamente representada pelo Grupo Durazno (Bossi, 1966 apud Oliveira, 1997), denominação inicialmente atribuída a sedimentos aflorantes na região central do Uruguai, com área de aproximadamente $2.200 \mathrm{~km}^{2}$. Tal grupo abriga as formações geológicas: Cerrezuelo (arenitos), Cordobés (folhelhos negros) e La Paloma (arenitos), os quais constituem um sistema petrolífero (Oliveira, 1997). O pacote sedimentar referente ao Grupo Durazno 
corresponde, em subsuperfície, a espessuras variantes entre 190 e 280 metros, delimitadas, tanto na base quanto no topo, por discordâncias estratigráficas de expressividade regional.

A formação Cordobés corresponde à formação pertencente ao Grupo Durazno de maior relevância para o presente estudo em virtude de sua correlação com a formação Ponta Grossa, da Bacia do Paraná. Segundo Oliveira (1997), a formação Cordobés é litologicamente composta por folhelhos e folhelhos-sílticos, de coloração cinza-escura à preta, muito fossilíferos, micáceos, e com ocorrências significativas de pirita. Também estão presentes delgadas intercalações com arenitos cinza, micáceos e de granulação fina; resultado do contato gradativo desta com a formação geológica sobrejacente: formação La Paloma. Análises de poços estratigráficos na região de La Paloma, porção central do Uruguai, revelam para a formação Cordobés espessura máxima de 117 metros.

\section{HISTÓRICO DA EXPLORAÇÃO PETROLÍFERA NA BACIA}

Pesquisas visando jazidas petrolíferas na Bacia do Paraná tiveram início no Brasil em 1892, na região de Bofete, estado de São Paulo, por Eugênio Ferreira de Camargo; realizadas por meio de perfurações de poços com profundidade média de 500 metros, os quais só vieram a produzir água sulfurosa. Posteriormente, no início do século XX, em 1901 e 1902, novas pesquisas foram realizadas pela Companhia Cruzeiro do Sul, chefiada por Arthur B. Reardon, também sem resultados economicamente viáveis. Em 1906, o Governo do Estado de São Paulo realizou a primeira perfuração oficial de poços exploratórios, nas proximidades da cidade de Guarei; representado pelo governador Jorge Tibiriçá e pela Comissão de Geografia e Geologia do Estado de São Paulo. Embora não tivesse sido encontrada concentrações significativas de hidrocarbonetos, a amostragem resultou no conhecimento do perfil litológico presente na região (Galhano, 2006).

As primeiras iniciativas federais em prospecção petrolífera no Brasil tiveram início em 1919 por meio do Serviço Geológico e Mineralógico do Brasil; perfurando inicialmente os estados do Paraná e São Paulo sob comando do presidente Delfim Moreira. Em 1921, ocorreu a produção comercial de gás natural na bacia por meio de poços com cerca de 310 metros de profundidade (Formação Corumbataí). Em 1932, a Companhia de Petróleo do Brasil, chefiada por Monteiro Lobato, realizou perfurações que atingiram a camada de basaltos presente na bacia sedimentar (cerca de 1.076 metros de profundidade), entretanto, sem grande retorno econômico. Em 1946, foi organizada a Sociedade Brasileira de Sondagens, sob a direção técnica de Silvio Fróes de Abreu, a qual desenvolveu um dos mais extensos programas de exploração de 
hidrocarbonetos na Bacia do Paraná, tendo também suas atividades encerradas por falta de retorno econômico, em 1950. A partir de 1953, com a Lei 2004, a exploração de hidrocarbonetos no Brasil passou a ser monopólio federal, sendo exclusivamente executado pela Petrobras (Yoshida, 1978 apud Galhano, 2006).

No período de 1953 a 1974, foi desenvolvido pela Petrobras um grande esforço sistemático para exploração de hidrocarbonetos na Bacia do Paraná: foram realizados 71 poços exploratórios e aplicação de diferentes métodos de prospecção, geralmente de caráter experimental, tais como aeromagnetometria, gravimetria e sísmica de reflexão; atividades as quais contribuíram para o acervo de informações acerca da bacia. No entanto, estes estudos foram geograficamente concentrados à uma faixa territorial equivalente a cerca de apenas $30 \%$ da extensão total da bacia sedimentar; e obtiveram resultados pouco promissores em sísmica de reflexão devido à presença de camadas basálticas na formação geológica, cobertura a qual corresponde à aproximadamente $70 \%$ da bacia, dificultando a interpretação desses dados sísmicos. Além de dificuldades associadas à aplicação de técnicas geofísicas, a cobertura basáltica teria contribuído ao craqueamento térmico em rochas potencialmente geradoras de hidrocarbonetos, promovendo a supermaturação destas e a consequente degradação dos hidrocarbonetos; bem como a fraca estruturação bacia que implica na redução de estruturas acumuladoras, fatores evidenciados na ausência de acumulações significativas de petróleo na região (Galhano, 2006). Posteriormente, e a partir do desenvolvimento de mais estudos referentes à geologia da Bacia do Paraná, conclui-se que, apesar dos fatores limitantes à acumulação de hidrocarbonetos anteriormente descritos, a bacia apresentava litologia favorável à geração e à reservatórios petrolíferos; os quais poderiam vir a ser explorados a partir de mecanismos de exploração e produção não convencionais, foco do presente estudo.

\section{CENÁRIO ENERGÉTICO BRASILEIRO}

\subsection{Usina Termoelétrica de Uruguaiana}

A AES Uruguaiana iniciou suas atividades em 2000 na cidade de Uruguaiana, estado do Rio Grande do Sul sob a autorização de operar como produtora independente de energia elétrica pelo prazo de 30 anos (contados a partir de 26 de junho de 1997). A usina possui capacidade instalada de 639,9 megawatts (MW) e possui duas turbinas de combustão com capacidade de 187,5 MW cada e uma turbina à vapor, com capacidade de $265 \mathrm{MW}$. A usina corresponde à primeira usina termoelétrica a operar a partir de gás natural no Brasil; combustível comparativamente menos poluente em relação aos demais combustíveis fósseis utilizados para termoeletricidade: carvão mineral e óleo diesel (AES Uruguaiana S.A., 2014). 
A usina termoelétrica está com suas atividades paralisadas desde abril de 2009 devido à interrupção total no fornecimento de gás natural por parte de sua única fornecedora, a empresa argentina Yacimientos Petrolíferos Y Fiscales S.A.(YPF), desde maio de 2008; interrupção a qual determinou a paralisação das atividades operacionais da usina desde esse data. Ainda em 2009, a companhia AES Uruguaiana apresentou um requerimento de arbitragem contra a YPF devido à quebra do contrato de fornecimento, pleiteando o pagamento de indenização. A decisão favorável deu-se em maio de 2013, porém o litígio segue em discussão na corte arbitral, sendo sua conclusão prevista para 2017. No final de 2012, o Ministério de Minas e Energia (MME), conjuntamente à AES Uruguaiana, Petróleo Brasileiro S.A. (Petrobras), Companhia de Gás do Estado do Rio Grande do Sul (Sulgás), Transportadora Sulbrasileira de Gás (TSB) e Operador Nacional do Sistema (ONS), iniciou negociações visando o retorno da operação da usina durante um período de 60 dias. As operações foram parcialmente retomadas em 06 de fevereiro de 2013 (inicialmente com potência de 164 MW e, posteriormente, por meio de ciclo combinado, de 244 MW). Em 2014, o funcionamento da usina foi novamente autorizado pelo MME, a operar de forma excepcional e temporária, gerando cerca de $240 \mathrm{MW}$ durante o período de 9 de março a 16 de maio de 2014 (AES Uruguaiana S.A., 2014).

Desde a interrupção no fornecimento de combustível para a usina (gás natural), em abril de 2009, esta interrompeu suas atividades e iniciou um programa de manutenção e conservação da usina (hibernação); decisão tomada com a finalidade de redução de custos e a preparação da usina para a possível retomada de atividades no futuro. A partir do reconhecimento da necessidade de geração, de forma excepcional e temporária, da usina pelo MME durante o período de 2013 a 2014, esta registrou uma geração líquida de 322,1 GW em 2014, valor 35\% superior ao registrado no ano anterior (de 239,0 GW). A retomada do funcionamento da usina durante esse período requereu investimentos da companhia AES Uruguaiana para a retirada do estado de hibernação da mesma, sendo este valor ressarcido por meio de Encargos de Serviço do Sistema (ESS) no valor de R\$22,5 milhões, contabilizado pela Câmara de Comercialização de Energia Elétrica (CCEE), em setembro de 2013. Em 2014, foram ressarcidos, no processo de liquidação da CCEE, R\$ 259 milhões, sendo também pleiteado, junto à Agência Nacional de Energia Elétrica (ANEEL), o ressarcimento de R \$ 3 milhões para cobrir custos adicionais associados ao processo. De modo geral, esse retorno operacional da usina durante 2013 e 2014 resultou na apuração de uma receita bruta de $\mathrm{R}$ \$ 265,5 milhões em 2014 e R \$ 188,9 milhões em 2013. Tal elevação nos custos foi relacionada à fatores como o aumento da geração de energia (de 188,9 GW em 2013 para 322,1 GW em 2014) e ao aumento no preço do combustível requerido, gás natural, também registrado no período: a ausência de insumo do recurso 
desencadeou o aumento dos preços, além da consequente necessidade de importação de gás natural liquefeito (GNL), também associado à custos mais elevados. A importação de GNL é intermediada pela Petrobras (combustível importado da Nigéria e Trinidad Tobago), posteriormente, o GNL é entregue para a Sulgás, distribuidora de gás natural do Rio Grande do Sul, que contrata a regaseificação e o transporte do energético em território argentino e, depois, em território nacional, para atendimento à térmica. Nesse contexto de consumo de maior volume de gás e maiores preços, os custos e despesas operacionais da empresa, contabilizados em um total de $\mathrm{R} \$ 171,2$ milhões, correspondem a um aumento de $44 \%$ no comparativo entre 2013 e 2014 (AES Uruguaiana S.A., 2014). 


\section{ANÁLISE COMPARATIVA}

Tabela 11 - Análise comparativa dos parâmetros essenciais à ocorrência de gás natural não convencional entre as formações geológicas Marcellus, Barnett, Eagle Ford, Irati e Ponta Grossa.

\begin{tabular}{|c|c|c|c|c|c|}
\hline $\begin{array}{l}\text { Parâmetros } \\
\text { Comparativos }\end{array}$ & Marcellus & Barnett & Eagle Ford & Irati & Ponta Grossa \\
\hline $\begin{array}{l}\text { Idade } \\
\text { Geológica }\end{array}$ & Devoniano médio & Mississipiano superior & Cretáceo superior & Permiano inferior & Devoniano médio \\
\hline Litologia & $\begin{array}{lr}\text { Folhelhos } & \begin{array}{r}\text { negros } \\
\text { carbonosos, } \\
\text { radioativos, }\end{array} \\
\text { concreções } & \text { carbonáticas; } \\
\text { Folhelhos enriquecidos } \\
\text { em sílica e matéria } \\
\text { orgânica. }\end{array}$ & $\begin{array}{l}\text { Folhelhos } \quad \text { negros densos, } \\
\text { silicosos, } \\
\text { fossilíferos e ricos em matéria } \\
\text { orgânica; } \\
\begin{array}{l}\text { cristalinos, Carbonatos } \\
\text { fossilíferos; }\end{array} \text { Folrolíferos e } \\
\text { altamentes negros } \\
\text { sílica (mais rúpteis). }\end{array}$ & 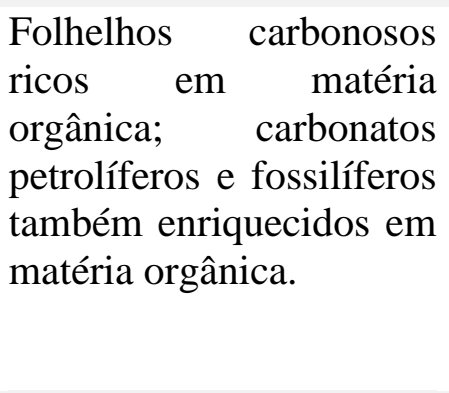 & $\begin{array}{l}\text { Folhelhos negros } \\
\text { enriquecidos em matéria } \\
\text { orgânica amorfa e com } \\
\text { lentes carbonáticas; } \\
\text { calcáreos dolomíticos. }\end{array}$ & $\begin{array}{l}\text { Folhelhos negros } \\
\text { laminados e carbonosos, } \\
\text { folhelhos siltosos, siltes } \\
\text { localmente carbonosos, } \\
\text { fossilíferos e micáceos, } \\
\text { com intercalações } \\
\text { areníticas. }\end{array}$ \\
\hline $\begin{array}{l}\text { Composição } \\
\text { Mineralógica } \\
\text { Predominante } \\
\text { (\% volume) }\end{array}$ & $\begin{array}{l}\begin{array}{l}\text { Sílica }(10-20 \%) ; \\
\text { argilominerais } \quad(35 \%) ; \\
\text { carbonatos }(50 \%)\end{array}\end{array}$ & $\begin{array}{l}\text { Sílica }(35-50 \%) \text {; argilominerais } \\
(<35 \%) \text {; carbonatos }(20 \%)\end{array}$ & $\begin{array}{l}\text { Sílica } \quad(15-20 \%) ; \\
\text { argilominerais }(15-30 \%) \text {; } \\
\text { carbonatos }(40-90 \%)\end{array}$ & $\begin{array}{l}\text { Sílica } \quad(40-55 \%), \\
\text { Argilominerais }(45-60 \%)\end{array}$ & $\begin{array}{lr}\geq & \text { Sílica } \\
\text { (comparativamente } & \text { à } \\
\text { Irati) } & \end{array}$ \\
\hline $\begin{array}{l}\text { Mineralogia } \\
\text { (\% volume) }\end{array}$ & $\begin{array}{l}27-31 \% \text { quartzo, 9-34\% } \\
\text { ilita, 1-7\% complexo de } \\
\text { argilominerais, } 0-4 \% \\
\text { clorita, 3-48\% calcita, } 0- \\
10 \% \text { dolomita, } 0-4 \% \\
\text { feldspato sódico, } 5-13 \% \\
\text { pirita, e } 0-6 \% \text { gipso. }\end{array}$ & $\begin{array}{l}30-50 \% \text { quartzo, } 27 \% \text { ilita e } \\
\text { traços de esmectita, } 8-19 \% \\
\text { calcita e dolomita, } 7 \% \\
\text { feldspato, } 5 \% \text { matéria orgânica, } \\
5 \% \text { pirita, } 3 \% \text { siderita, e traços } \\
\text { de material fosfático e cobre. }\end{array}$ & $\begin{array}{l}15-20 \% \text { quartzo, } 15-30 \% \\
\text { argilominerais, } 40-90 \% \\
\text { calcita e dolomita + } \\
\text { matéria orgânica + pirita. }\end{array}$ & $\begin{array}{l}\text { Mica e argilominerais } \\
(60-70 \%) \text {, titanita e rutilo } \\
(1-8 \%) \text {, matéria orgânica } \\
(20-30 \%)\end{array}$ & - \\
\hline Área $\left(\mathbf{k m}^{2}\right)$ & 60.000 & 13.000 & 12.140 & $\begin{array}{l}770.000 \text { (cerca de } 70 \% \text { da } \\
\text { extensão total da bacia) }\end{array}$ & $\begin{array}{l}1.100 .000 \text { (toda a } \\
\text { extensão da bacia no } \\
\text { Brasil) + continuidade no }\end{array}$ \\
\hline
\end{tabular}


Espessura (m)

Profundidade

(m)

Tipo de

Querogênio

Predominate

Ro (\%)

COT (\%)

Tmáx $\left({ }^{\circ} \mathrm{C}\right)$

Maturidade

Termal
15-200 (tipicamente 15- 15-300 (tipicamente 45-180). $80)$

600-3.000

1.200-2.500

II e I

predominante)

\section{1,60 (máximo de 3.5)}

1-10

470

Rochas

predominantemente

supermaturas

termogênico). Associada

à profundidade de

soterramento e fluxo

térmico em zonas de

falhas.

Classificação
da $\quad$ Bacia

Sedimentar

Retro-arco, assimétrica, Retro-arco,

assimétrica

Retro-arco, assimétrica,

delimitada por cinturões

delimitada

por cinturões

orogênicos

estruturais

soerguimento

$\operatorname{arcos}$

orogênicos proeminentes, arcos

delimitada por cinturões

orogênicos.

cambriano.

pré- cambriano.

Paleoambiente Deposicional

15-150 (tipicamente 70)

$1.200-4.000$

II e III

1,4

$2-12$

335

Rochas que variam de imaturas à supermaturas. Associada à profundidade de soterramento atividade hidrotermal ao longo de zonas de falhas e fraturas.

\section{B}

águas profundas, baixa circulação, coluna d'água
$20-40$ (tipicamente $\leq 20$ )
$\leq 3.000$
$\begin{aligned} & \text { I, II e III (tipos I e II } \\ & \text { predominantes) }\end{aligned}$
$1,1-1,6$
$1-23$ (média $\leq 2)$
$\leq 440$

Associada à taxa de depocentro da bacia; e à influência de corpos magmáticos intrusivos

Rochas

predominantemente

imaturas.

Intracratônica.

Delimitações estruturais Baixa complexidade estrutural.

Bacia sedimentar de águas profundas, baixa circulação, coluna d'água
Uruguai

Durazno)

(Grupo

80 (tipicamente de 20 a 60)

$\leq 3.500$

II e III (tipo II predominante na porção oeste da bacia)

$\geq 1,35$

$1-3$ (média $\leq 2$ )

$430-500$

Associada à taxa de soterramento e à influência de corpos magmáticos intrusivos.

Rochas

predominantemente

supermaturas (domínio mais apropriado à geração de gás natural não convencional)

Intracratônica.

Delimitações estruturais. Baixa complexidade estrutural.

Bacia sedimentar de águas profundas, baixa circulação, coluna d'água 
estratificada, ambiente ambiente redutor na base, circulação, coluna d'água redutor na base, presença presença de matéria orgânica de matéria orgânica algácea-planctônica,

profundidade da lâmina d'água em torno de 100 a $300 \mathrm{~m}$.

Característica

\section{$\mathbf{s}$} Reservatório (\%) algácea-planctônica, estratificada, ambiente redutor na base, presença profundidade da lâmina d'água de matéria orgânica em torno de 150 a $200 \mathrm{~m}$.

algácea-planctônica, profundidade da lâmina d'água em torno de 100 $\mathrm{m}$.

$\varphi=3-6, \mathrm{k}=$ micro-nanodarcies, $\varphi=8, \mathrm{k}=$ micro$\mathrm{Sw}=25$ (sem água livre), $\mathrm{Sg}=$ nanodarcies, $\mathrm{Sw}=20$ 75 (gás alocado em poros (sem água livre), $\mathrm{Sg}=75$ intersticiais e microfraturas, e (gás alocado em poros o nanodarcies, $\mathrm{Sw}=30$ (sem água livre), $\mathrm{Sg}=70$ (gás alocado em poros intersticiais microfraturas, adsorvido à matéria orgânica e querogênio: 20-80\% ); pressão interna do reservatório: de 0.51 $\mathrm{psi} / \mathrm{ft}$ (sobrepressão) a 0.10-0.35 psi/ft (baixa pressão) adsorvido à matéria orgânica e intersticiais

e querogênio: 20-60\%); estágio de sobrepressão: $0.52 \mathrm{psi} / \mathrm{ft}$

microfraturas, orgânica e querogenio: $20-80 \%$ )pressão interna do reservatório: de 0.5 $0.8 \mathrm{psi} / \mathrm{ft}$, média de 0.65 psi/ft (sobrepressão) de matéria orgânica

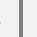
$0,2-0,8 ;$ IP $\leq 0,1$ estratificada, ambiente redutor na base, presença

estratificada, ambiente redutor na base, presença de matéria orgânica algácea-planctônica,

$\mathrm{S} 1=0,02-0,8 \mathrm{mgHC} / \mathrm{g}$ rocha; $\mathrm{S} 2=100-200$ $\mathrm{mgHC} / \mathrm{g}$ rocha; $\mathrm{S} 1+\mathrm{S} 2=$

$\mathrm{S} 2=6,6 \mathrm{mg} ; \mathrm{S} 1+\mathrm{S} 2=$ potencial para gás 


\section{CONSIDERAÇÕES FINAIS E CONCLUSÕES}

Visando o estabelecimento e desenvolvimento de uma indústria nacional de gás natural, a comprovação do potencial para ocorrência de grandes acumulações gasíferas continentais em sistemas petrolíferos de configuração geológica não convencional (gás natural não convencional) se torna de fundamental importância para o setor energético brasileiro; além de ressaltar à contribuição do conhecimento geológico no planejamento energético. Segundo aspectos econômicos, a atual produção de gás natural no Brasil provem essencialmente de reservas convencionais, as quais se concentra em áreas remotas (bacias sedimentares offshore, ou na região amazônica) e a consequente distância dos principais centros consumidores (regiões sul e sudeste do Brasil) requer elevados investimento em infraestrutura de distribuição e maiores custos associados. Além da relevância econômica e da potencial redução na dependência de importações de gás natural e consequente redução de custos, o gás natural apresenta vantagens em relação à outras fontes energéticas segundo aspectos ambientais: emissão de $\mathrm{CO}_{2}$ comparativamente reduzida em relação à outros combustíveis fósseis (carvão mineral e óleo combustível), além de representar menor grau de incertezas e riscos comparativamente à energia nuclear.

Diante desse cenário, a possibilidade de produção de gás natural a partir de reservatórios não convencionais, os quais se apresentam amplamente distribuídos em bacias sedimentares nacionais, por meio da implantação de técnicas exploratórias específicas (perfuração horizontal e fraturamento hidráulico); pode ir à incentivar a produção brasileira de gás natural não convencional, tornando este recurso mais competitivo no mercado petrolífero e potencialmente vir a modificar o panorama energético nacional (Tassinari, 2015).

No contexto de bacias sedimentares brasileiras com potencial gerador de gás natural não convencional (shale gas), destaca-se a bacia sedimentar do Paraná, em virtude de seu elevado potencial para ocorrência deste recurso conforme apresentando no presente trabalho (configuração geológica favorável, potencial gerador e armazenador nas formações Irati e Ponta Grossa, parâmetros geoquímicos correspondentes aos encontrados nos principais campos produtores de shale gas atualmente: Barnett, Marcellus e Eagle Ford, nos Estados Unidos); e de sua proximidade aos principais centros consumidores de energia no Brasil, abrangendo os estados de SP, PR, SC, RS, GO,MT, MS e MG. Além disso, a concentração da produção de eletricidade no Brasil em seu potencial hidráulico, torna a matriz energética brasileira relativamente vulnerável à variações climático-sazonais; como a crise hídrica de 2014, 
impactando significativamente empreendimentos hidrelétricos e desencadeamento aumento no custo da geração de energia, transmitido à população.

Com base nos dados apresentados na tabela comparativa acima, pode-se inferir o potencial para ocorrência de gás natural não convencional nas formações Irati e Ponta Grossa, Bacia do Paraná, no Brasil, sendo este potencial comparativamente estabelecido conforme dados de formações comprovadamente produtoras desse recurso (Barnett, Marcellus e Eagle Ford, nos Estados Unidos)

Considerando a idade geológica das formações analisadas, as formações brasileiras datam de períodos favoráveis à geração de hidrocarbonetos e condizentes aos intervalos temporais em que as formações norte-americanas se enquadram (predominantemente entre o Devoniano e Permiano, média de 391,8 a 275,6 Ma).

Com base na litologia das formações, todas apresentam similaridade composicional: constituídas por folhelhos negros ricos em matéria orgânica e frações carbonosas, com variações nas concentrações e sílica e argila. Considerando essa variação na composição mineralógica predominante, ambas as formações brasileiras (Irati e Ponta Grossa) são favoráveis à implantação da técnica exploratória de faturamento hidráulico devido ao elevado conteúdo de sílica em suas composições, que deve ser superior a 30\% do volume total com frações carbonáticas presentes, segundo Andrews (2013), uma característica que atribui aspecto rúptil ao folhelho e a consequente maior eficácia no faturamento induzido do mesmo. Comparadas entre si, as formações brasileiras diferem, mineralogicamente, nas frações carbonosas e silicosas, sendo a Formação Ponta Grossa mais favorável à implantação da técnica mencionada devido seu maior teor de sílica e carbonato.

Segundo o aspecto área de ocorrência, ambas as formações brasileiras são suficientemente extensas para a exploração economicamente viável de hidrocarbonetos, sendo a formação Ponta Grossa a de maior extensão em km², prolongando-se ao longo de toda a Bacia do Paraná até o Uruguai, onde se apresenta em maior espessura e profundidade. Analisando estes parâmetros, as formações brasileiras apresentam relativa desvantagem em relação às formações americanas, as quais apresentam espessuras e profundidades maiores e, consequentemente, maior potencial para geração de gás natural. Entretanto, parâmetros como o elevado teor de matéria orgânica e maturidade termal podem vir à compensar essa desvantagem: a presença de corpos ígneos intrusivos na Bacia do Paraná possivelmente contribui com o processo de maturação termal dessas formações presentes. Além disso, a possibilidade de geração de gás natural de origem biogênica pode mudar esse cenário, sendo este independente de elevada taxa de maturação, espessura e profundidade, e sim relacionado à 
degradação bacteriogênica da matéria orgânica (Tassinari, 2015). Ainda segundo esses aspectos, as formações brasileiras ainda se encaixam nos parâmetros considerados favoráveis à geração de gás natural não convencional, mencionados previamente: espessura necessariamente superior a 15 metros e profundidade superior a 1.500 metros. Comparativamente, a Formação Ponta Grossa apresenta maior espessura e profundidade em relação à Formação Irati, apresentando valores progressivamente mais elevados em direção ao sul da bacia do Paraná, estado do Rio Grande do Sul, e no Uruguai, áreas de maior proximidade ao local do estudo (Uruguaiana).

Considerando aspectos tectônicos e diagenéticos das bacias sedimentares analisadas, estas se assemelham: geralmente intracratônicas, de baixa complexidade estrutural e formadas em um contexto paleoambiental de águas profundas com baixa circulação de água e ambiente redutor e rico em matéria orgânica.

De acordo com Andrews (2013), os valores mais adequados de carbono orgânico total (COT) para gás natural não convencional em folhelhos são superiores a $2 \%$. O tipo de matéria orgânica mais adequada é o Querogênio tipo II, sendo o tipo I também favorável (propriedades que favorecem a Formação Irati). O Querogênio tipo I é mais favorável à geração de petróleo (oil prone); apesar de poder gerar gás, mas em quantidades inferiores aos do tipo II (gas prone). Valores ideais de reflectância da vitrinita variam entre 1.1 e $3.5 \%$ (preferencialmente entre 1.75 e $3.0 \%$ ), margem onde se apresentam ambas as formações Irati e Ponta Grossa.

Com base na análise comparativa realizada, pode-se concluir que ambas as formações pertencentes à Bacia do Paraná (Formações Irati e Ponta Grossa) apresentam potencial moderado a elevado para a geração e armazenamento de gás natural não convencional, sendo a Formação Ponta Grossa a de maior potencial gerador e armazenador dentre estas e, consequentemente, a de exploração mais recomendada para a produção nesse recurso na região sul do Brasil. 
AES BRASIL. AES Uruguaiana. Disponível em <http://www.aesbrasil.com.br/Paginas/aesbrasil.aspx> Acessado em 08/2015.

ÓLEO, GÁS NATURAL E BIOCOMBUSTÍVEIS (ANP). Disponível em < http://www.anp.gov.br/?id=2803>. Acessado em 08/2015.

ANDERSON, J., SIMPSON, M., BASINSKI, P., BEATON, A., BOYER, C., Producing Natural Gas from Coal. Oil Field Review. 2003.

ANDREWS, I.J. 2013. The Carboniferous Bowland Shale gas study: geology and resource estimation. British Geological Survey for Department of Energy and Climate Change, London, UK.

AMARAL, Sérgio Estanislau do. Geologia e petrologia da formação Irati (Permiano) no estado de São Paulo. Bol. IGA, São Paulo, $2016 . \quad$ Disponível em $<$ http://ppegeo.igc.usp.br/scielo.php?script=sci_arttext\&pid=S010039251971000100001\&lng $=$ pt\&nrm=iso $>$. Acesso em 29 jan. 2016.

ARTHUR, P.C., SOARES, P.C. 2002. Revista Brasileira de Geociências. 32 (4), 2002, pp.433448.

AZEVEDO DA SILVA, C.G. 2007. Caracterização geoquímica orgânica das rochas geradoras de petróleo das formações Irati e Ponta Grossa da Bacia do Paraná. Dissertação de Mestrado. Instituto de Química, Universidade Federal do Rio Grande do Sul. Porto Alegre, Dezembro de 2007.

BARBOSA, H. C. R., CASTRO, A. B. de, CUPERTINO, D. F., DIAS, K. D. N., PECCINI, T. L. Geologia estrutural, tectônica e sedimentação das bacias intracratônicas: Solimões, Amazonas, Parnaíba e Paraná. 142 f. Trabalho Final de Curso (Curso de Especialização em Projeto de Análise de Bacias: Módulo Geologia do Petróleo Faculdade de Geologia, Universidade do Estado do Rio de Janeiro, Rio de Janeiro, 2007.

BOYCE, M. Subsurface stratigraphy and petrophysical analysis of the Middle Devonian interval of central Appalachian basin: West Virginia and southwest Pennsylvania: PhD thesis proposal. 2009. West Virginia University, 23 p.

BOWKER, K.A., Recent developments of the Barnett shale play, Fort Worth basin, inLaw, B.E., and Wilson, M., eds., Innovative gas exploration concepts symposium: Rocky Mountain Association Geologists and Petroleum Technology Transfer Council, 2002. Oct 2002, 16 p.

BRUNER, K.R., SMOSNA, R., A Comparative Study of the Mississipian Barnett Shale, Fort Worth Basin, and Devonian Marcellus Shale, Appalachian Basin. U.S.Department of Energy. 2011. DOE/NETL-2011/1478.

CHAPMAN, R.E., Petroleum Geology: A Concise Study. Elsevier Scientific Publishing Company. Amsterdam, Oxford, New York. 1976.

CHARPENTIER, R.R. \& COOK, T.A., 2011. USGS methodology for assessing continuous petroleum resources. USGS Open-File Report. 2011-1167. 
COMPANHIA DE GÁS DE SÃO PAULO. Gás natural na indústria. Disponível em <http://www.comgas.com.br/quero_industria/gasnatural/segmentos.asp> Acessado em $08 / 2015$.

COMPANHIA DE GÁS DO ESTADO DO RIO GRANE DO SUL. Disponível em $<$ http://www.sulgas.rs.gov.br/sulgas> Acessado em 08/2015.

DAS VIRGENS, G.B., Revisão Bibliográfica dos Folhelhos com Gás da Formação Barnett, Texas, EUA: um exemplo de reservatório não convencional. Trabalho Final de Graduação. Universidade Federal da Bahia. Instituto de Geociências. p.85. 2011.

DEUTSCHE WELLE. Meio Ambiente. Disponível em < http://www.dw.de/brasil-quer-usarfraturamento-hidr\%C3\%A1ulico-para-explorar-g\%C3\%A1s-de-xisto/a-16794512> Acessado em $03 / 2014$.

DURHAM, L.S. Appalachian basin's Marcellus - the new target: AAPG Explorer, March 2008: http://www.aapg.org/explorer/2008/03mar/marcellus.cfm, accessed July 2009.

DURHAM, L.S., Barnett Shale play still going strong: American Association Petroleum Geologists Bulletin, 2005, v. 86, p. 1,921-1,938.

ENERGY INFORMATION ADMINISTRATION, EIA. Disponível em <http://www.eia.gov/energy_in_brief/article/about_shale_gas.cfm> Acessado em 08/2015.

ENGELDER, T., Structural geology of the Marcellus and other Devonian gas shales: geological conundrums involving joints, layer-parallel shortening strain, and the contemporary tectonic stress field: Pittsburgh Association of Petroleum Geologists Field Trip. 2008a. (Sept. 1213, 2008), 96 p.

ENGELDER, T., and Lash, G.G., Marcellus Shale play's vast resource potential creating stir in Appalachia: The American Oil and Gas Reporter, May 2008, 7 p.

EOFF, J.D., Global Predition of Continuous Hydrocarbon Accumulations in Self-Sourced Reservoirs. U.S. Geological Survey Open-File Report 2012-1091. 2012.

EXXONMOBIL. About Natural Gas. 2012. Disponível em $<$ http://aboutnaturalgas.com/content/natural-gas/tight-and-shale-gas/> Acessado em 03/2014. FORBES. Disponível em <http://www.forbes.com/sites/energysource/2012/12/07/surpriseside-effect-of-shale-gas-boom-a-plunge-in-u-s-greenhouse-gas-emissions/> Acessado em $03 / 2014$.

FRACFOCUS. Chemical Disclosure Registry. Hidraulic Fracturing: The Process. 2010. Disponível em < http://fracfocus.org/hydraulic-fracturing-how-it-works/hydraulic-fracturingprocess $>$ Acessado em 03/2014.

FUGITA, A.M. Quarta Rodada de Licitações. Bacia do Parnaíba. Superintendência de Definição de Blocos. ANP - Agência Nacional do Petróleo, Gás Natural e Biocombustíveis. Rio de Janeiro, 2004.

HALLIBURTON. Coalbed Methane: Principles and Practices. 2007. Disponível em < http://www.halliburton.com/public/pe/contents/Books_and_Catalogs/web/CBM/H06263_Cha p_01.pdf> Acessado em 11/2014. 
HARPER, J.A. The Marcellus Shale-an old "new" gas reservoir in Pennsylvania: Pennsylvania Geology. 2008. $\quad$ v. $\quad 38, \quad$ p. $2-13$ : http://www.dcnr.state.pa.us/topogeo/pub/pageolmag/pdfs/v38n1.pdf, accessed July 2009.

HENTZ, T.F., and RUPPEL, Regional Stratigraphic and Rock Characteristics of Eagle Ford Shale in Its Play Area: Maverick Basin to East Texas Basin, Search and Discovery Article\#10325,(http://www.searchanddiscovery.com/pdfz/documents/2011/10325hentz/ndx_h entz.pdf.html) based on oral presentation at AAPG Annual Convention and Exhibition, Houston, Texas, USA, April 10-13, 2011.

HUBBERT, M.K., Energy Resources. National Academy of Sciences, Publication 1000-D, p.81-83. 1962.

KHAMSIN, S.A., Basic Properties of Reservoir Rocks. Department of Petroleum Engeneering. King Fahd University of Petroleum and Minerals. Dhahran, Saudi Arabia, 2004.

LANCASTER, D.E., McKetta, S., and Lowry, P.H., Research findings help characterize Fort Worth Basin’s Barnett Shale: Oil \& Gas Journal, 1993, v. 91, issue 10, p. 59-64.

LAW, B.E., Basin Centered Gas Systems. AAPG Bulletin, v.86, no.11. P.1891-1919. 2002.

LEE, D.S., Herman J.D., Elsworth, D., Kim, H., Lee H. A critical evaluation of unconventional gas recovery from the Marcellus shale, northeastern United States. KSCE. Journal of Civil Engineering. 2011. 15 (4):679-687.

LINK, P.K. Basic Petroleum Geology. Oil and Gas Consultants International (OGCI). Tulsa, OK. $3^{\text {rd }}$ edition. p.232. 2007.

LIMA GOMES, A.J. 2009. Avaliação de recursos geotermais da Bacia do Paraná. Tese de Doutorado. Observatório Nacional MCT. Coordenação de Pós-Graduação em Geofísica. Rio de Janeiro. ON, 2010.

LOUCKS, R.G., and RUPPEL, S.C., Mississippian Barnett Shale: lithofacies and depositional setting of a deep-water shale-gas succession in the Fort Worth Basin, Texas: American Association Petroleum Geologists Bulletin, 2007, v. 91, p. 579-601.

MAACK, R. 1947. Breves notícias sobre a geologia dos estados do Paraná e Santa Catarina. Arquivos de Biologia e Tecnologia. Curitiba, v.2, p. 63-154, 1947.

MAGOON, L.B. ; DOW, W.G. The Petroleum Systems: from source to trap. AAPG Memoir 60. Chapter 1. 1994.

MALAGUETA, D.C., A Dimensão Ambiental na Delimitação das Reservas de Óleos Não Convencionais: Os Casos do Canadá e do Ártico. UFRJ/COPPE, 2009. XV, p. 110. Rio de Janeiro, 2009.

MATSUTSUYU, B. South Texas Eagle Ford Shale Geology- Regional Trends, Recent Learnings, Future Challenges. Momentum Oil \& Gas. Developing Unconventional Gas Conference. Huston, 2011. Texas. October 10-12, 2011.

McCULLAGH, T., HART, B., Stratigraphic controls on production from a basin-centered gas system: Lower Cretaceous Cadotte Member, Deep Basin, Alberta, Canada. AAPG Bulletin, v.94, no.3. p.293-315. 2010. 
MENEZES, T.R., FILHO, J.G.M., ARAUJO, C.V., SOUZA, I.V., MENDONÇA, J.O., Fácies orgânica: conceitos, métodos e estudos de casos na indústria do petróleo. Revista Brasileira de Geociências. 80-96 junho de 2008.

MILANI, E.J., BRANDÃO, J.A.S.L., GAMBOA, L.A.P. Petróleo na Margem Continetal Brasileira: Geologia, Exploração, Resultados e Perspectivas. Brazilian Journal of Geophysics, V. 18(3), 2001.

MILANI, E.J. et al. 2007. Bacia do Paraná. Bol. Geoc. Petrobras 15(2):265-287.

MILANI, E. J. Evolução tectono-estratigráfica da Bacia do Paraná e seu relacionamento com a geodinâmica fanerozóica do Gondwana sul-ociden- tal. 1997. 2 v. Tese (Doutorado) Universidade Federal do Rio Grande do Sul, Porto Alegre, 1997.

MONTGOMERY, S.L., Jarvie, D.M., Bowker, K.A., and Pollastro, R.M., Mississippian Barnett Shale, Fort Worth basin, north-central Texas: Gas-shale play with multi-million cubic foot potential: American Association Petroleum Geologists Bulletin, 2005, v. 89, p. 155175 .

NORTON ROSE FULBRIGHT, 2013. Shale Gas Handbook: a quick-reference guide for companies involved in the exploitation of unconventional gas resources. Norton Rose Fulbright (NRF) 11/13 UK.

OLIVERIA S.F. Palinologia da sequência devoniana da Bacia do Paraná no Brasil, Paraguai e Uruguai: implicações biocronoestratigráficas, paleoambientais e paleogeográficas. Tese de Doutoramento. Instituto de Geociências. Universidade de São Paulo. São Paulo, 1997.

PARRA, P.A., Rubio, N., Ramirez, C., Guerra, V.A., Campos, I.R., Trejo, M.D., Olguin, J. Vargas, C.H., Valbuena, R., Soler, D.F., Weimann, M.I., Lujan, V., Bonningue, P., Reyes, P.G., Martinez, R., Munoz, R., Rodriquez, E., and Garcia, M., 2013, Unconventional Reservoir Development in Mexico: Lessons Learned From the Frist Exploratory Wells, Society of Petroleum Engineers, 2013. Unconventional Resources Conference- USA held in The Woodlands, Texas, USA, 10-12 April 2013, SPE 164545.

PEREIRA, E., CARNEIRO, C.D., BERGAMASCHI, S., ALMEIDA, F.F.M., Evolução das Sinéclises Paleozóias: Províncias Solimóes, Amazonas, Parnaíba e Paraná. Geologia do Brasil. Cap.V.p.374-418. 2008.

PETRONOTÍCIAS. Disponível em < http://www.petronoticias.com.br/archives/19096> Acesso em 03/2014.

RADOVIC, L.R., Energy and Fuels in Society: Analysis of Bills and Media Report. McGrawHill Custom Publishing. 1997.

ROEN, J.B., Geology of the Devonian black shales of the Appalachian basin: Organic Geochemistry. $1984, \quad$ v. $\quad 5, \quad$ p. 254:http://www.eesi.psu.edu/news_events/EarthTalks/2009Spring/materials2009spr/Roen84B lkShDevorggeoch.pdf, accessed July 2009. 
ROSTIROLLA, S.P., Análise de Incertezas de Sistemas Petrolíferos. Revista Brasileira de Geociências. 29(2):261-270. 1999.

SCHLUMBERGER. Tight Gas and Oil. 2013. Disponível em < http://www.slb.com/services/technical_challenges/unconventional_resources/tight_gas.aspx > Acessado em 03/2014.

SEKITAN NO HON, H. Mengenal CBM (Coal Bed Methane). 2010. Disponível em < http://imambudiraharjo.wordpress.com/2010/01/19/mengenal-cbm-coal-bed-methane>

Acessado em 11/2014.

SERVIÇO GEOLOGICO DO BRASIL. CPRM. 2013. Disponível em < http://geobank.sa.cprm.gov.br/> Acessado em 03/2014.

SILVA, C.G.A., Caracterização Geoquímica Orgânica das Rochas Geradoras de Petróleo das Formações Irati e Ponta Grossa da Bacia do Paraná. Dissertação de Mestrado. Instituto de Química. Universidade Federal do Rio Grande do Sul. Porto Alegre, 2007.

SOEDER, D.J., and Kappel, W.M., Water resources and natural gas production from the Marcellus Shale: U.S. Geological Survey. 2009. Fact Sheet 2009-3032, 6 p.

TASSINARI, C.C.G. 2015. Notas de Aula: Introdução à Exploração de Gás e Óleo Não Convencional. Instituto de Energia e Ambiente. Universidade de São Paulo.

TASSINARI, C. Notas de Aula. Petróleo e Gás Natural Não Convencional. Instituto de Energia e Ambiente. Universidade de São Paulo. 2015

TISSOT, B.P. WELTE, D.H. Petroleum Formation and Occurrence: A New Approach to Oil and Gas Exploration, xviii. p.538. Berlin, Heidelberg, New York: Springer-Verlag. ISBN 3 540086986.1978.

U.S. GEOLOGICAL SURVEY. Map of Assessed Shale Gas in the United States, 2012.Disponível em < http://pubs.usgs.gov/dds/dds-069/dds-069-z/DDS-69-Z_pamphlet.pdf> Acessado em 08/2015.

US ENERGY INFORMATION ADMINISTRATION (EIA), 2013, Technically Recoverable Shale Oil and Shale Gas Resources: An Assessment of 137 Shale Formations in 41 Countries Outside the United States. Available at: http://www.eia.gov/analysis/studies/worldshalegas/ U.S.ENERGY INFORMATION ADMINISTRATION (EIA). Updates to the EIA Eagle Ford play maps. U.S.Department of Energy. 2015 Washington DC. https://www.eia.gov/maps/pdf/eagleford122914.pdf

WERNER, A.K., VINK, S., WATT, K., Jagals, P. 2014. Environmental health impacts of unconventional natural gas development: A review of the current strength of evidence. Sciences of the Total Environment. 505 (2015) 1127-1141.

WHITE, I.C. 1908. Relatório sobre coal measures e rochas associadas ao sul do Brasil. Rio de Janeiro: Comissão das Minas de Carvão de Pedra do Brasil, 1908. 300 p.

WILLIAMS, J.H., The Marcellus Shale Play: geology, development and water resource impact mitigation. New York Water Science Center. U.S.Geological Survey (USGS). 2012. 
YERGIN, D. The Quest: Energy, Security, and the Remaking of the Modern World. Published by the Penguim Group. 2011, 2012.

YOSHIDA, R. 1978. História da pesquisa de petróleo no Brasil e no estado de São Paulo. São Paulo, 1978.

ZALÁN, P.V. et al. 1990. A Bacia do Paraná. In: Gabaglia G.P.R. \& Milani E.J. (coords.) Origem e evolução de bacias sedimentares. Bol. Técn. Petrobras, p. 135-168.

ZALÁN, P. V.; WOLFF, S.; ASTOLFI, M. A. M.; VIEIRA, I. S.; CONCEIÇÃO, J. C. J.; APPI, V. T.; SANTOS NETO, E. V.; CERQUEIRA, J. R.; MARQUES, A. The Paraná Basin, Brazil. In: LEIGHTON, M. W.; KOLATA, D. R.; OLTZ, D. F.; EIDEL, J. J. (Ed.). Interior cratonic basins. Tulsa: American Association of Petroleum Geologists, 1990. p. 681-708. (AAPG.Memoir, 51).

ZA ZA ENERGY Company Corporation, Presentation, 2013, Investor Presentation December 2014, p. 14. http://www.zazaenergy.com/

ZOU, C., ZHANG, G., YANG, Z., TAO, S., HOU, L., ZHU, R., YUAN, X., RAN, Q., LI, D., WANG, Z., Concepts, Characteristics, Potential and Technology of Unconventional Hydrocarbons: On Unconventional Petroleum Geology. Petroleum Exploration and Development. Research Paper. V.4 (4). P. 413-428. 2013. 